\title{
المقدمةُ الطليـة
}

$$
\text { شعـر المرقشي الأكبر }
$$

$$
\begin{aligned}
& \text { للدكتهـور } \\
& \text { حسام هحمبل عله }
\end{aligned}
$$

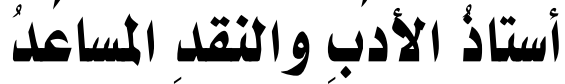

$$
\begin{aligned}
& \text { ووكيل كلية اللدراسات الإسلامية والعربية } \\
& \text { لبنين بالشرقية } \\
& \text { جامعة الأزهر الشريف بالثرئ }
\end{aligned}
$$


= المجلد الأول من العدد الخامس والعشرين لحولية كلية الدراسات الإسلامية والعربية للبنات ـ بالإسكندرية سـ المقدمة الطليلة فى شعر المرقش الأكبر - دراسة تحليلية ونقدية 


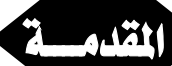

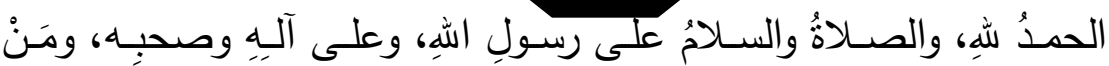

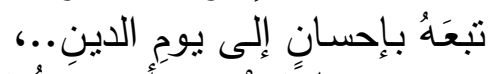

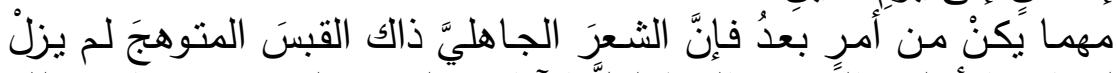

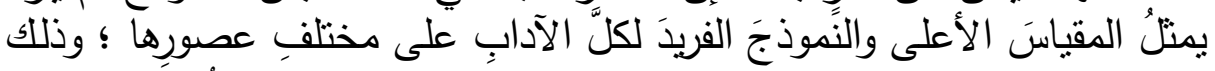

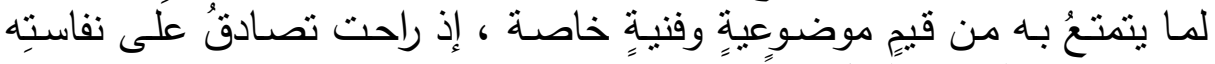

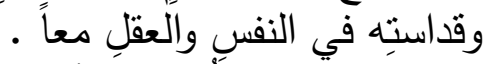

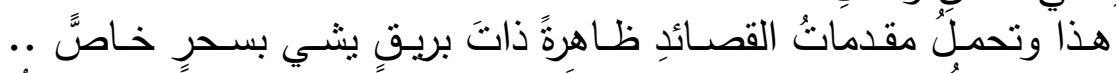

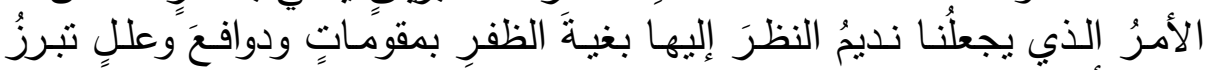

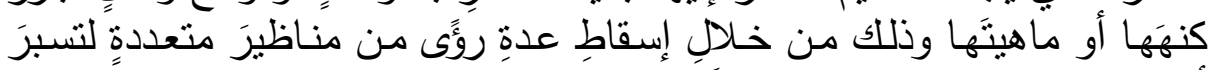

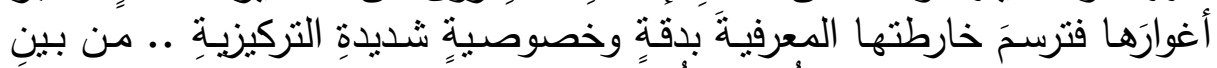

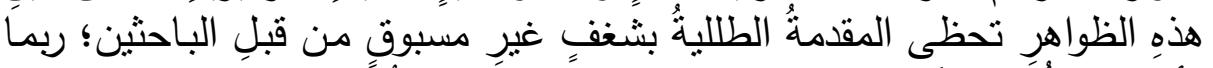

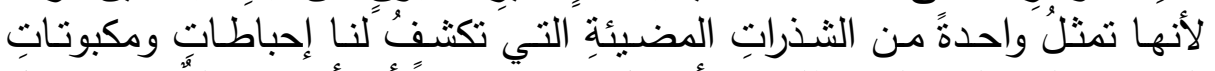

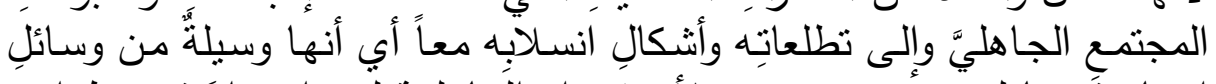

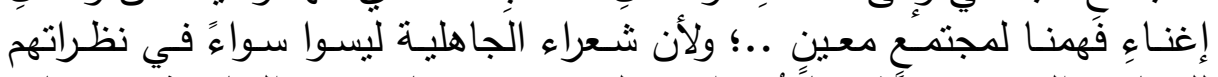

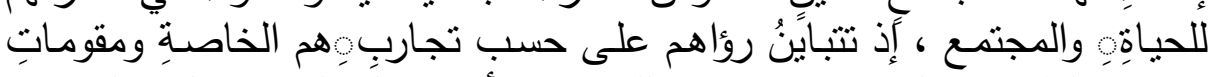

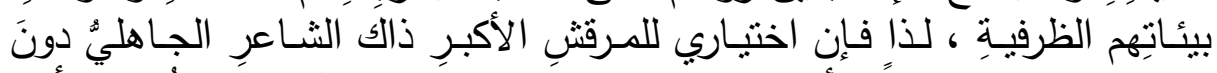

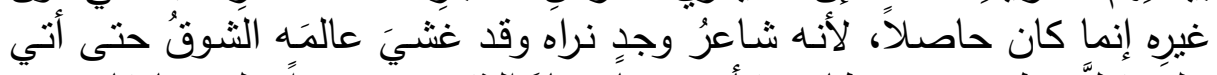

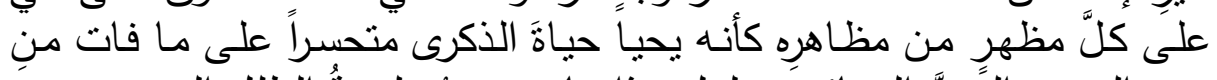

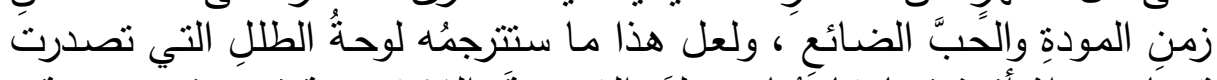

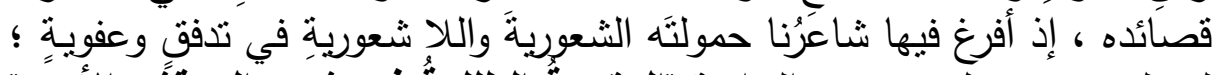

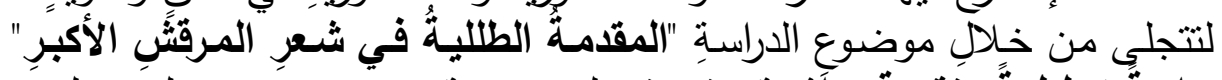

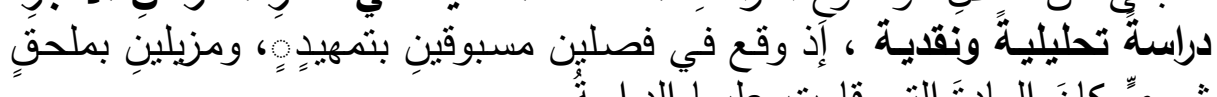

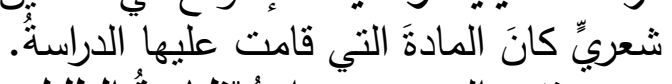

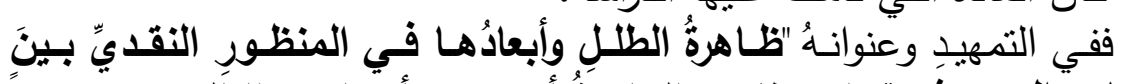

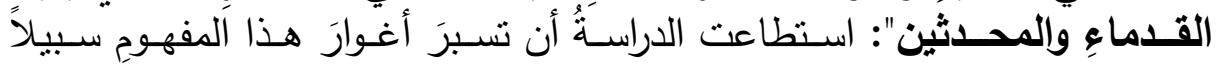

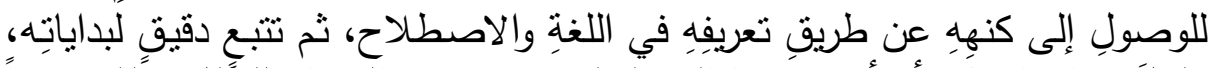

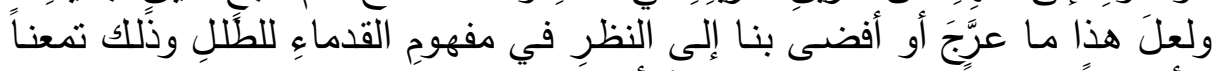

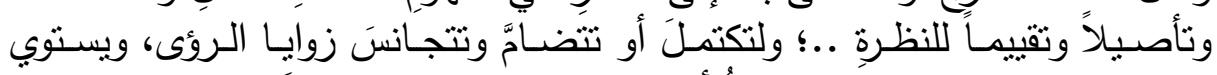

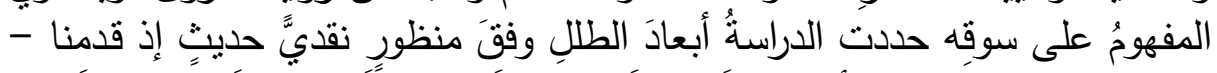

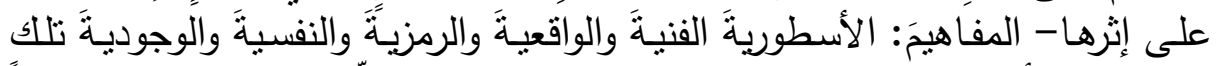

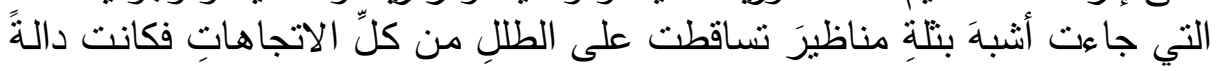




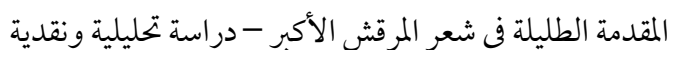

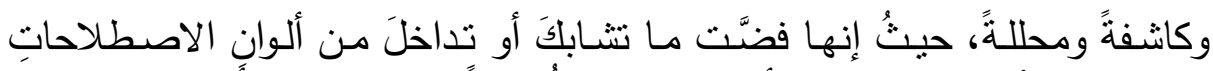

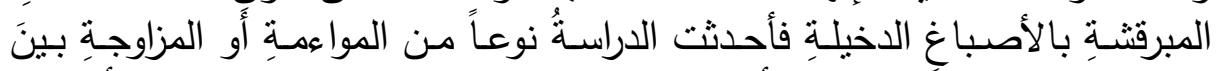

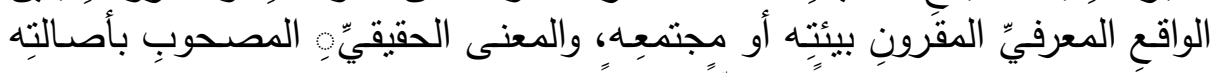

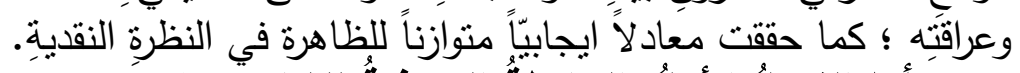

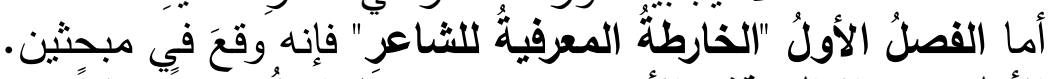

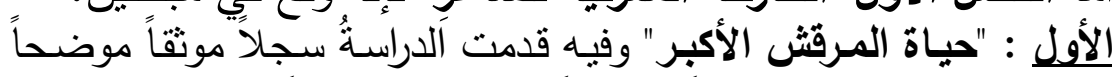

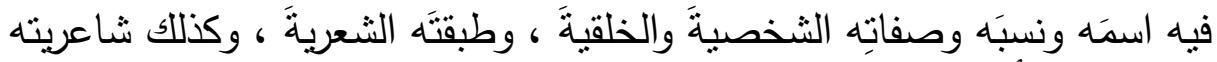

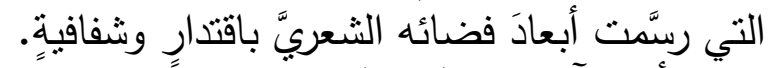

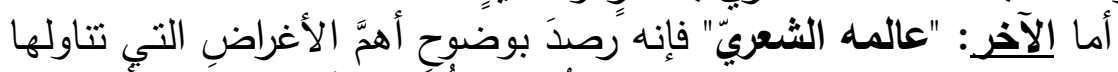

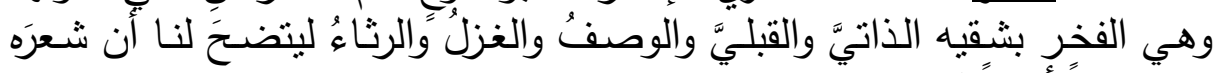

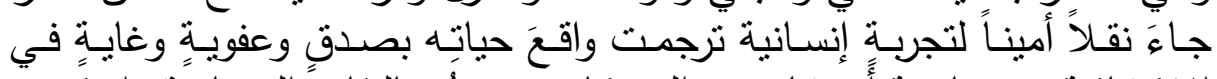

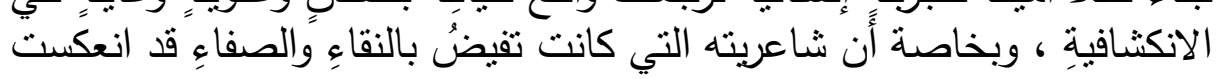

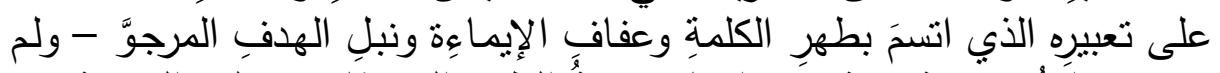

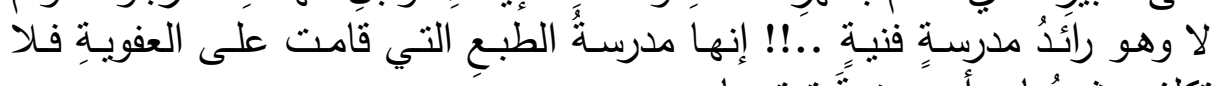

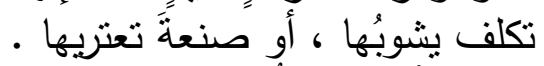

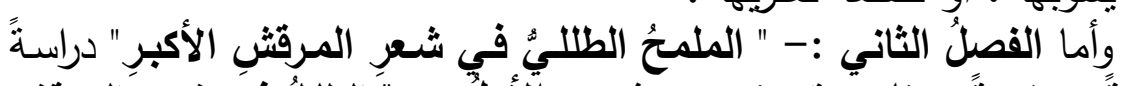

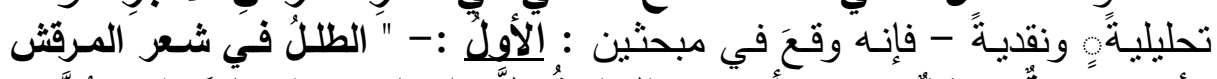

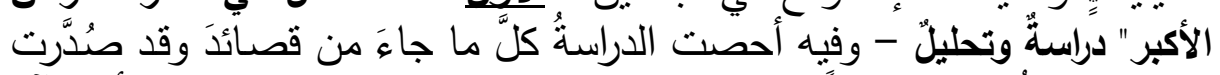

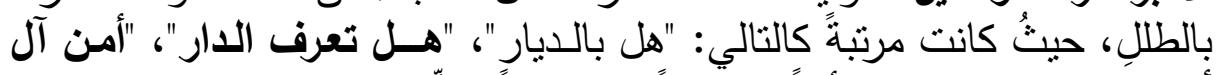

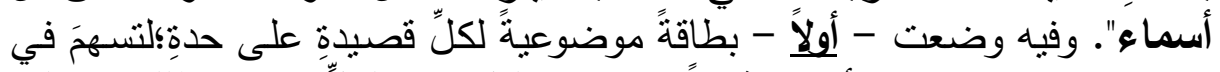

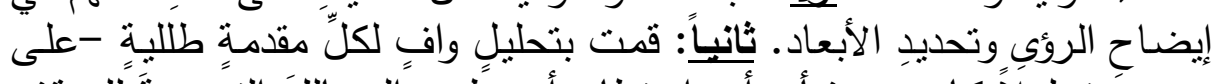

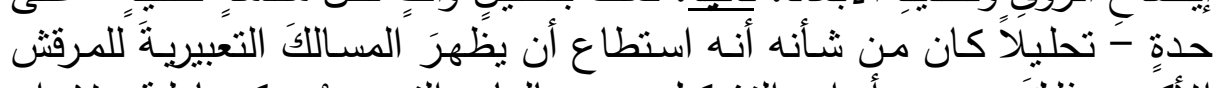

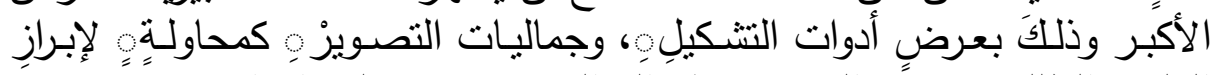

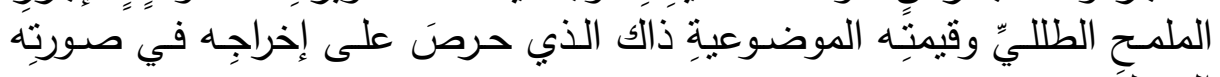

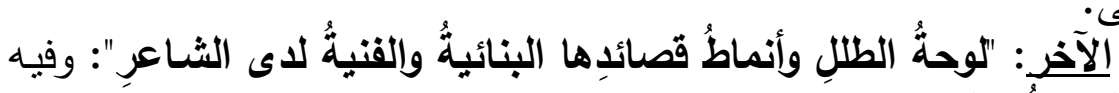
الفضلى

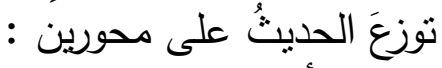

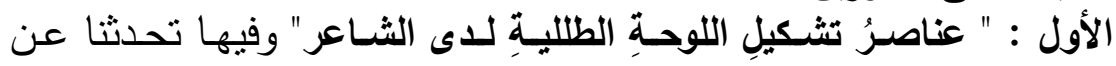

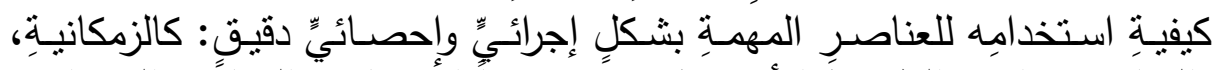

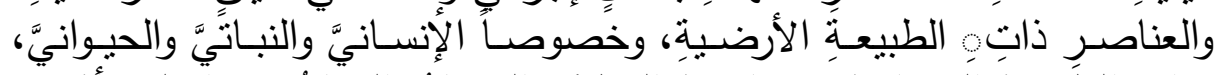

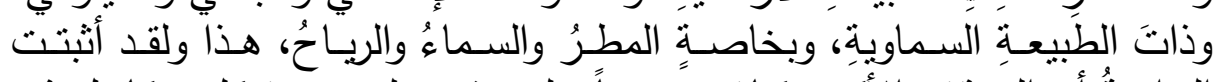

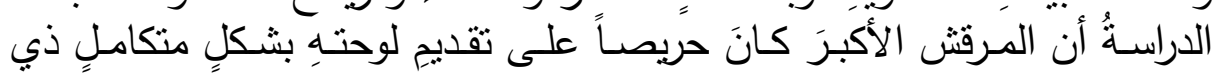




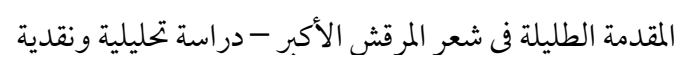

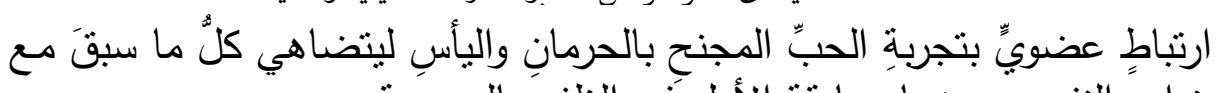

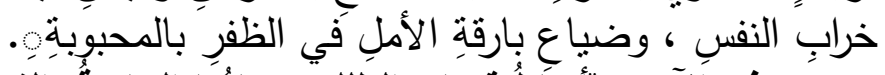

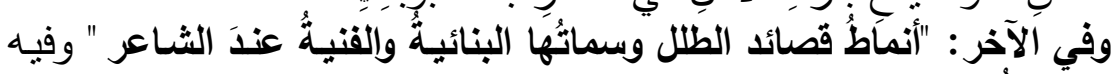

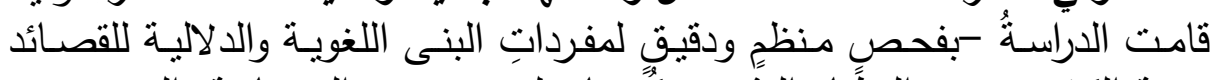

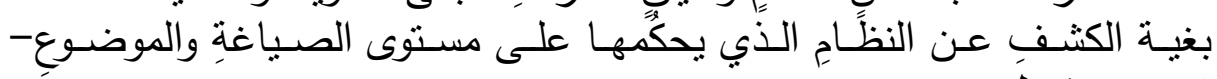

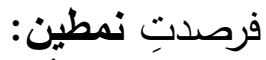

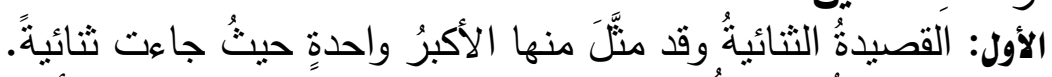

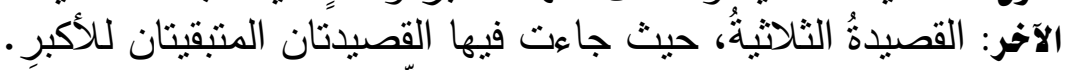

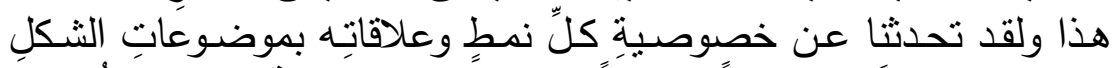

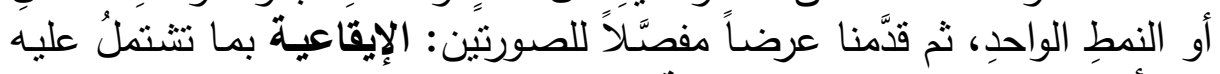

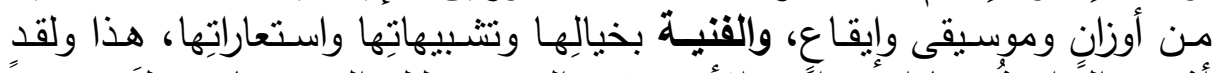

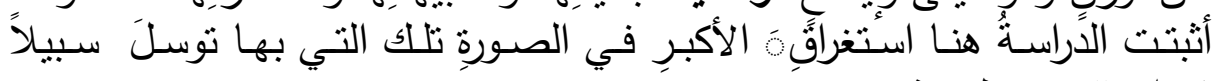

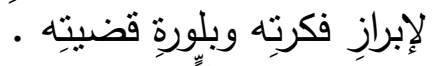

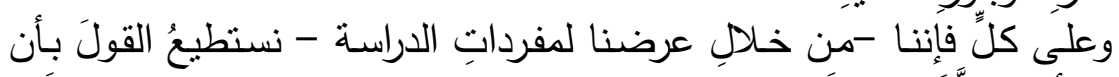

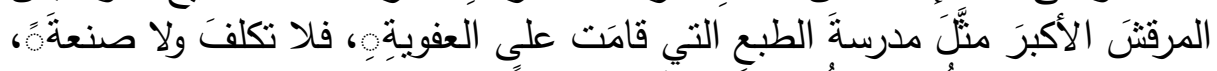

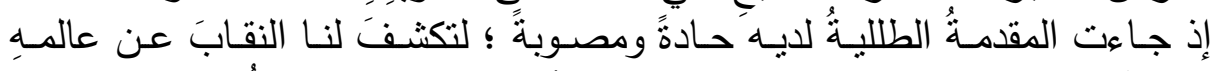

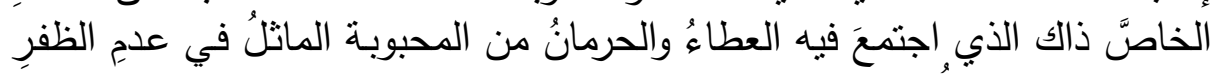

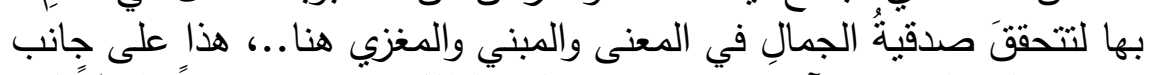

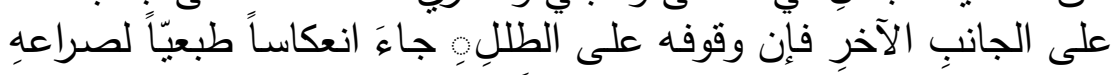

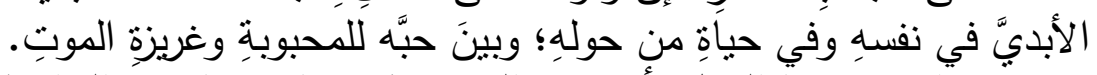

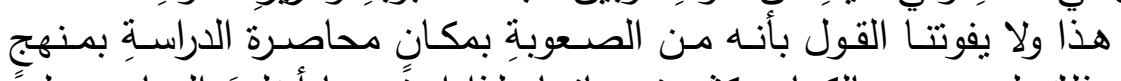

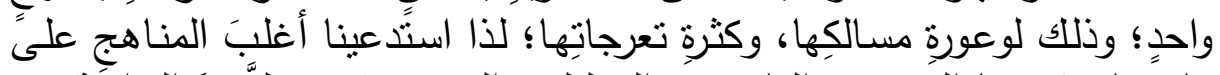

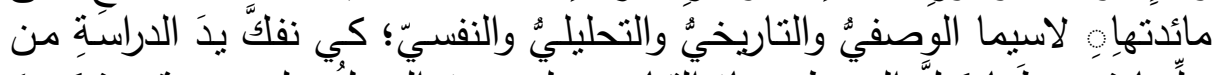

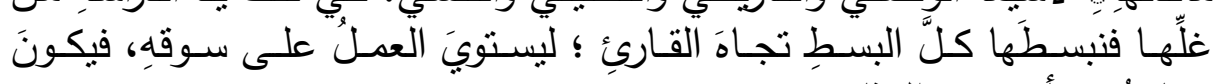

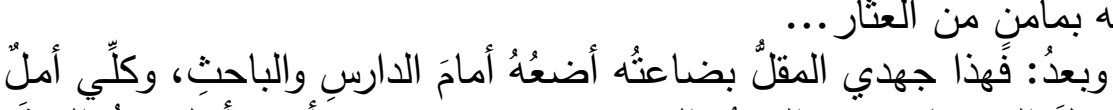

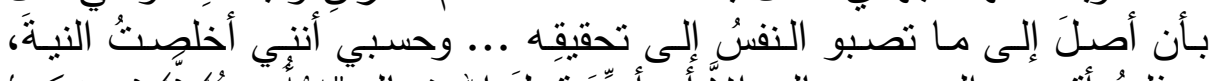

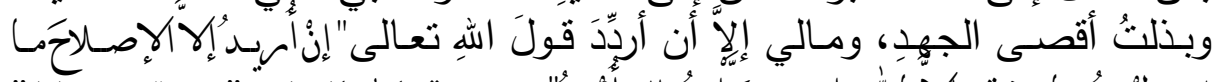

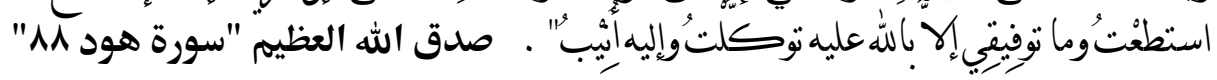
"الباحث " 


\section{الطللُ لغَّة:}

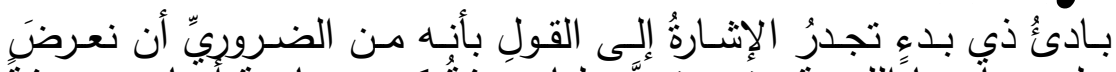

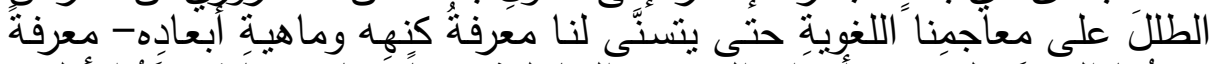

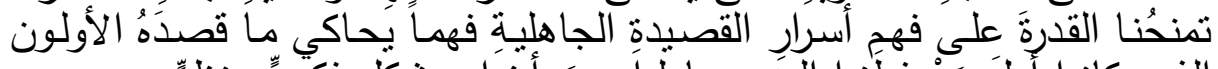

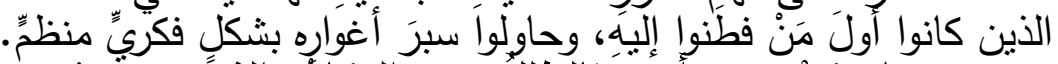

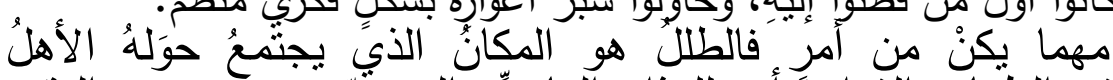

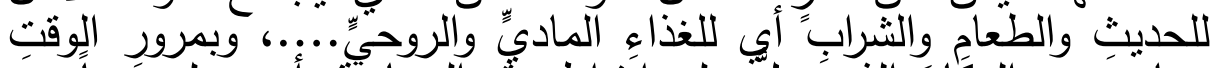

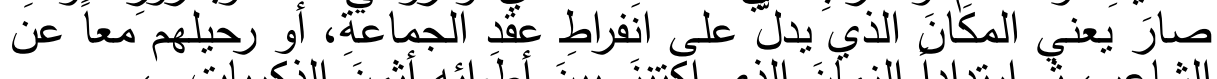

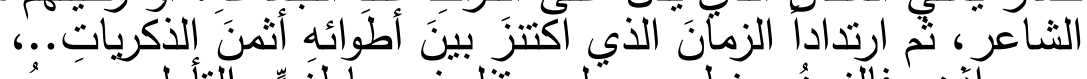

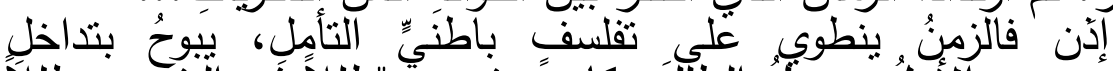

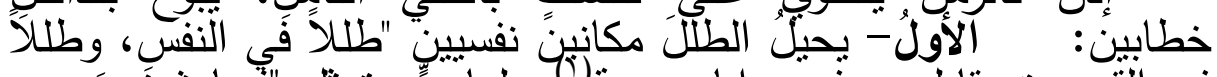

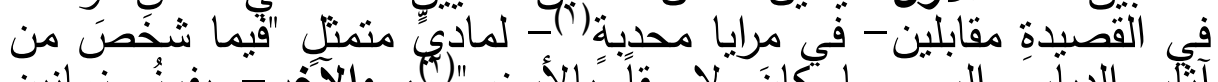

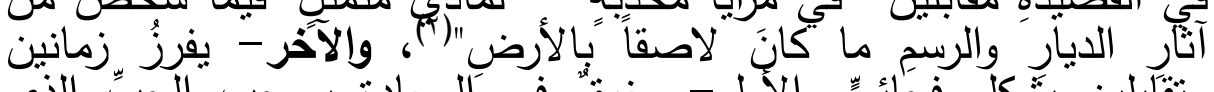

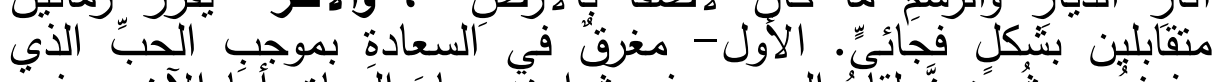

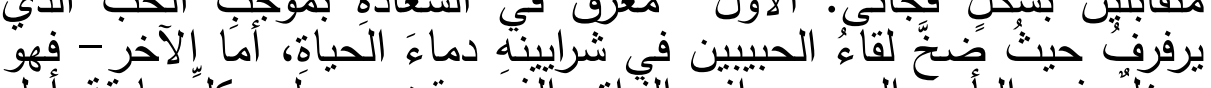

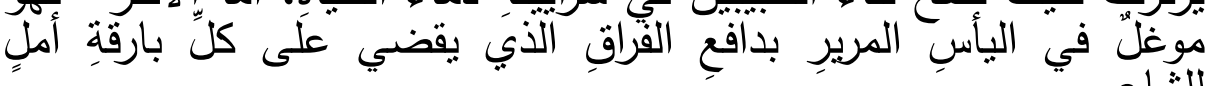

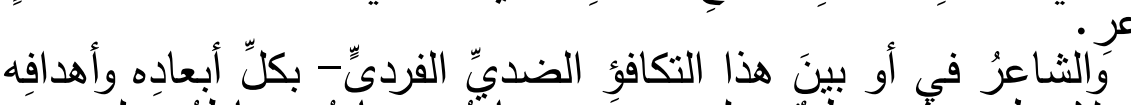

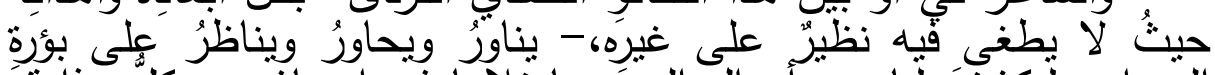

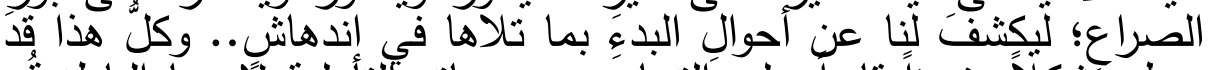

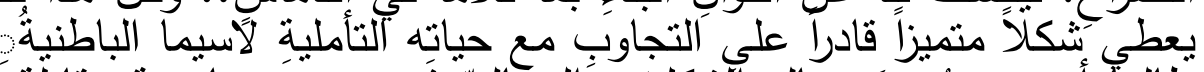

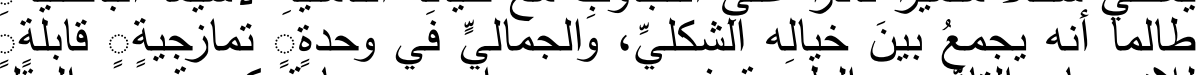

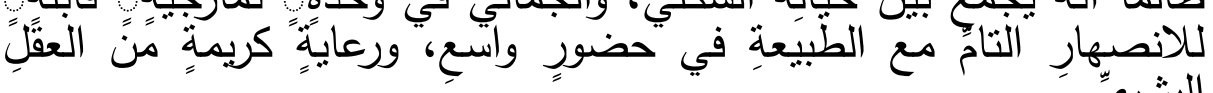
البشريِّاِ

\section{واصطاحة):}

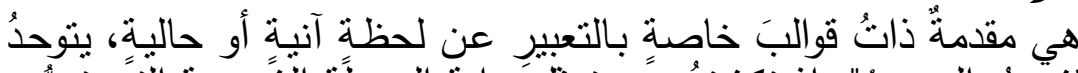

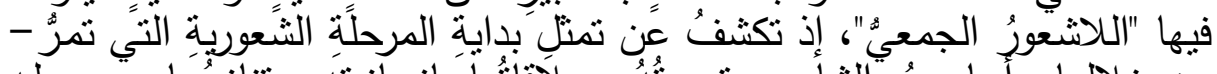

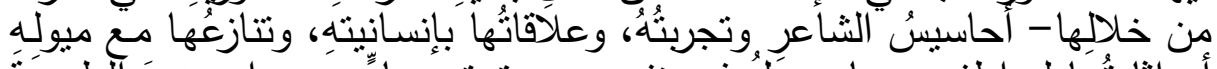

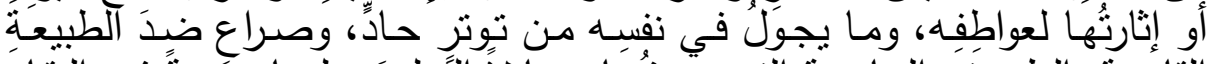

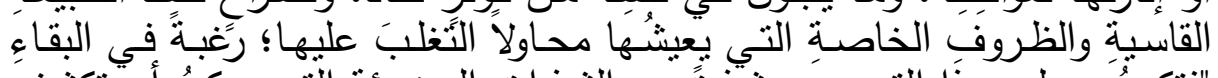

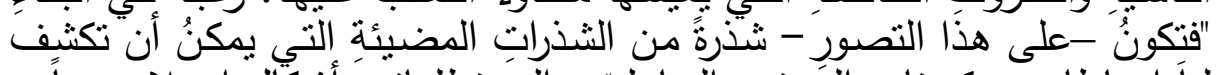

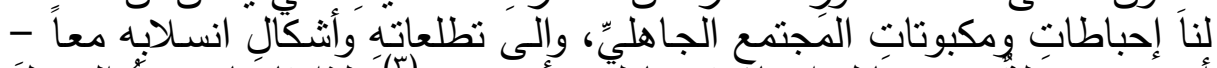

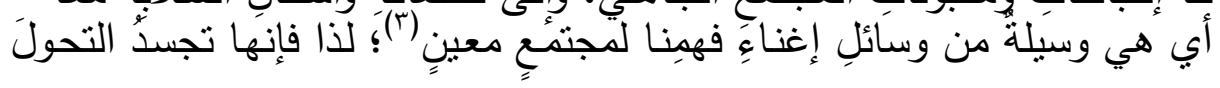

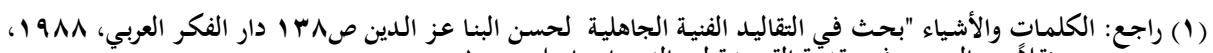

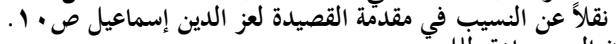




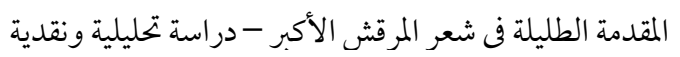

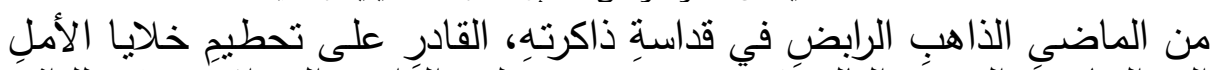

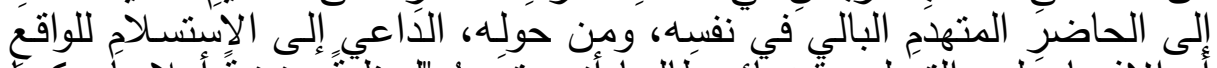

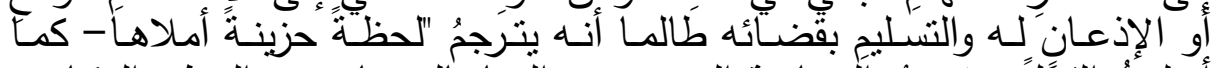

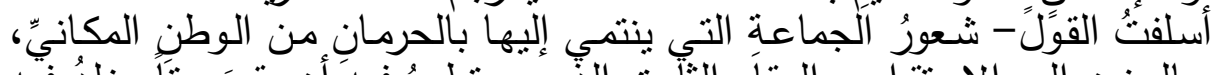

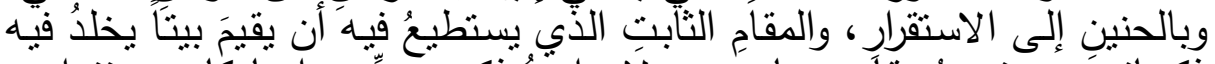

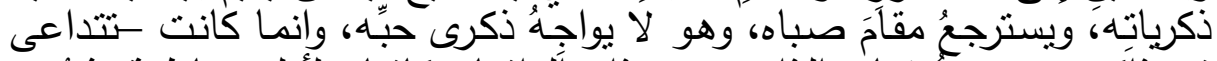

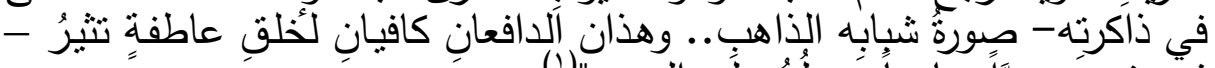

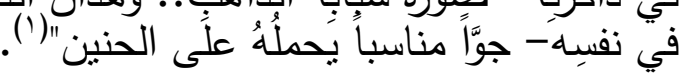

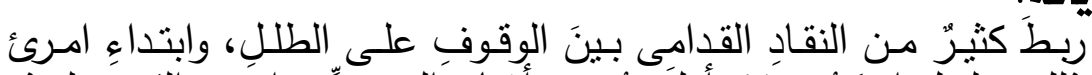

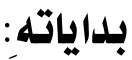

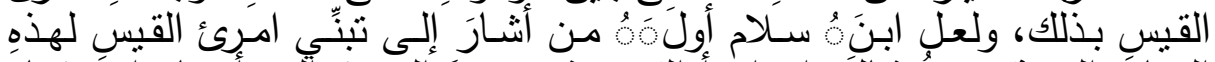

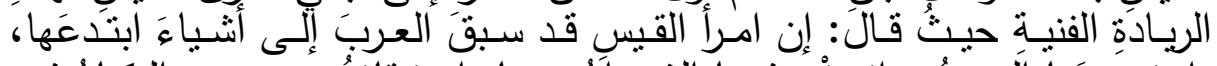

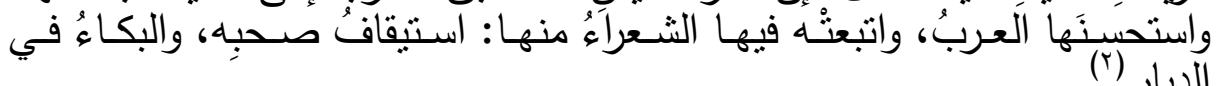

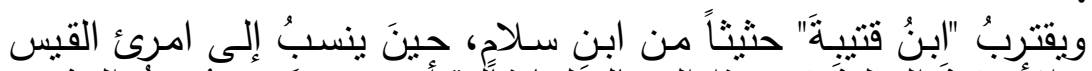

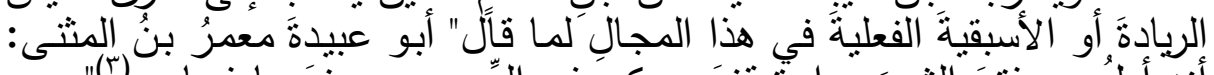

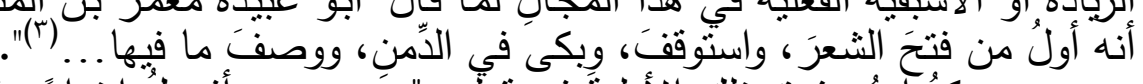

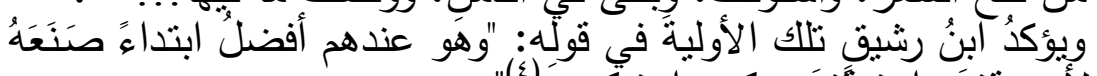

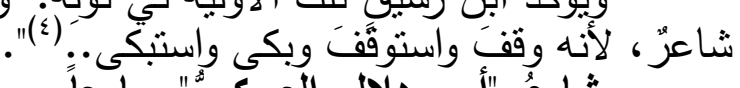

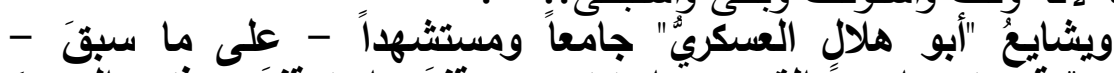

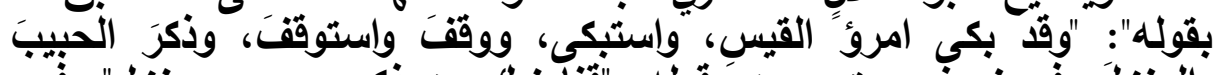

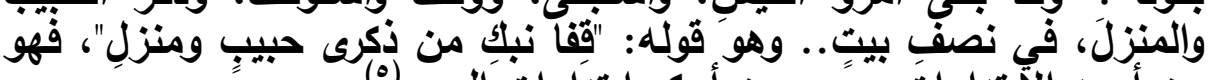

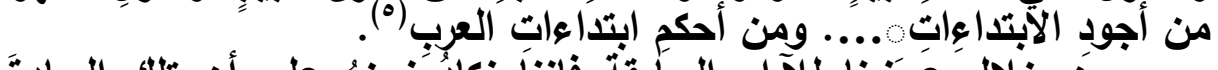

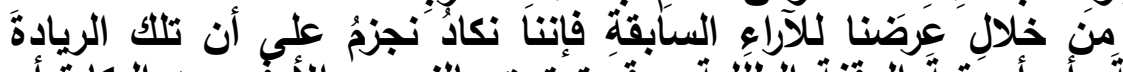

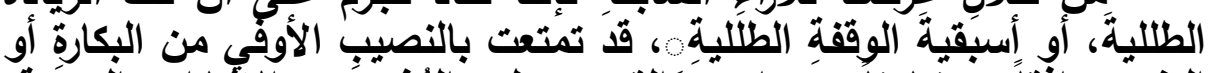

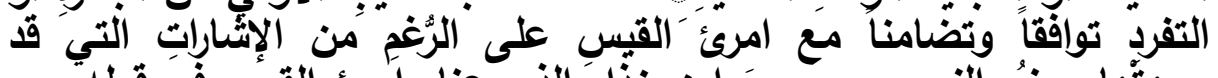

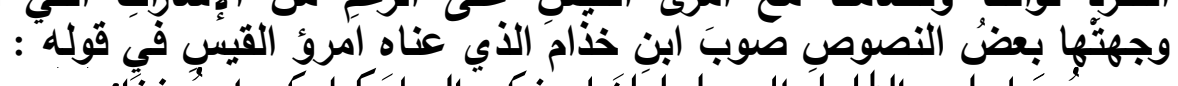

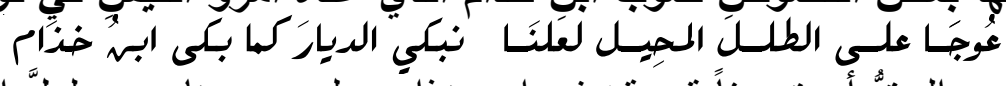

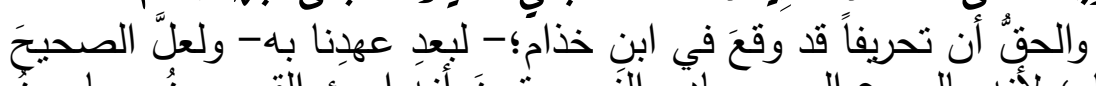

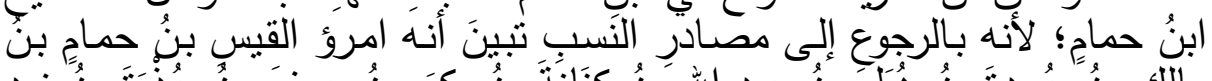

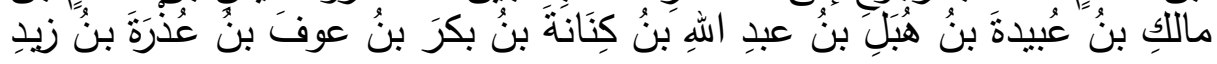

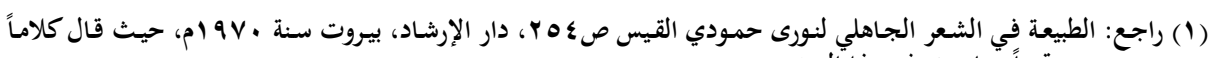

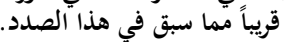

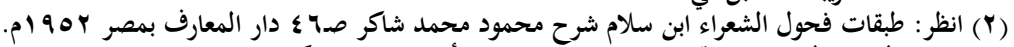

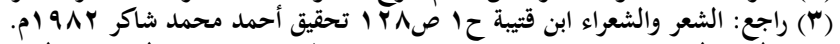

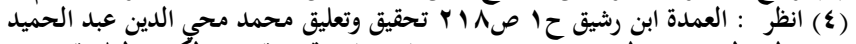

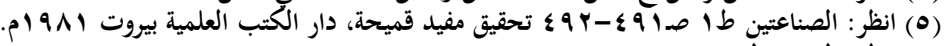

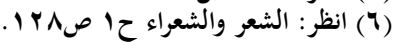




\section{المقدمة الطليلة في شعر المرقش الأكبر - دراسة تحليلية ونقدية}

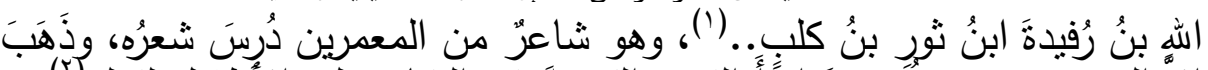

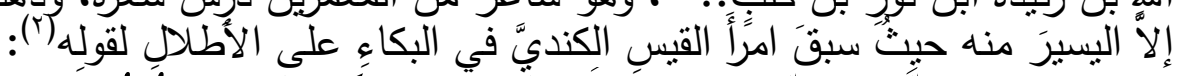

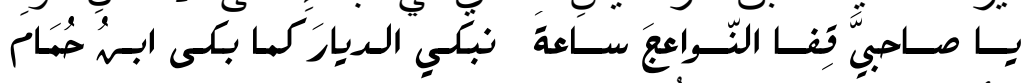

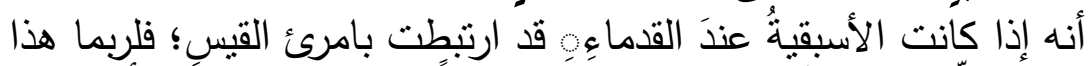

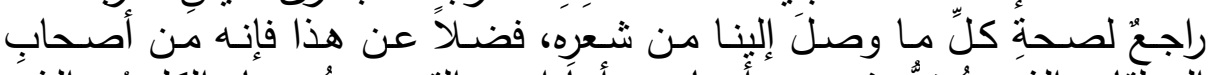

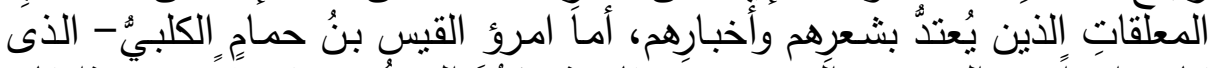

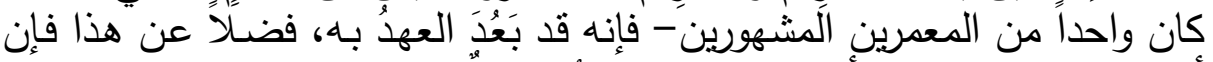

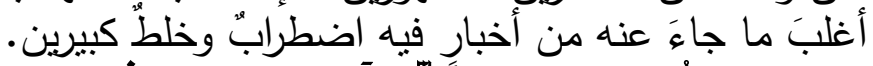

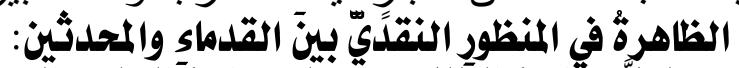

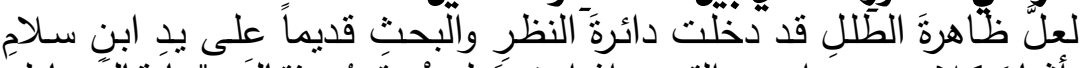

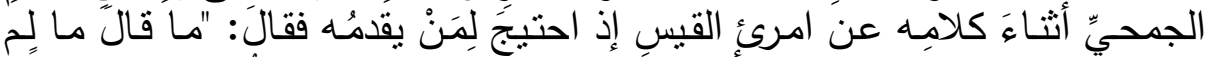

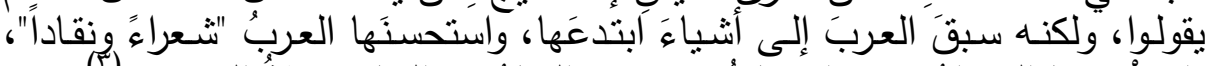

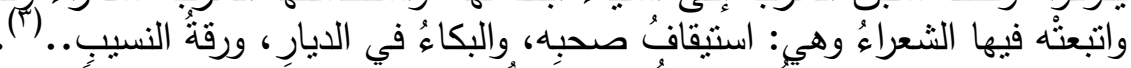

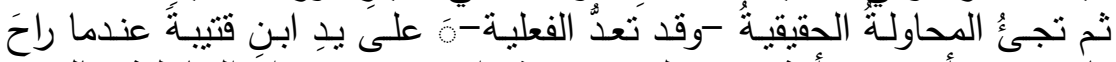

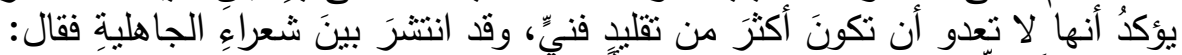

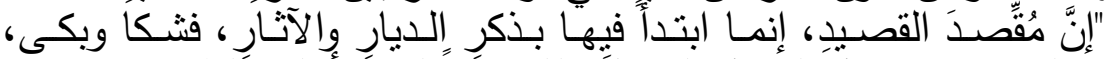

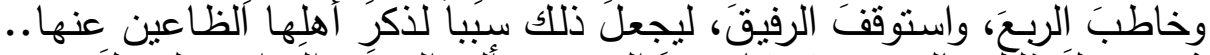

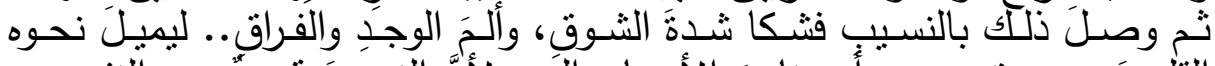

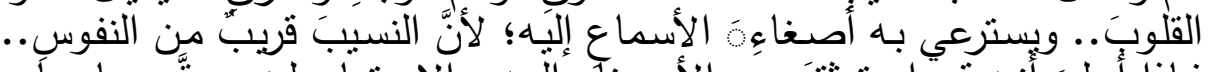

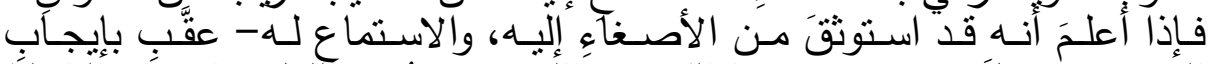

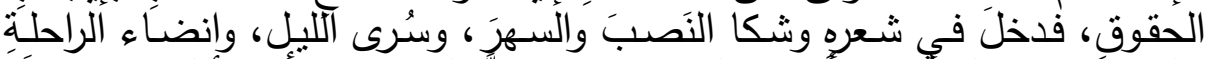

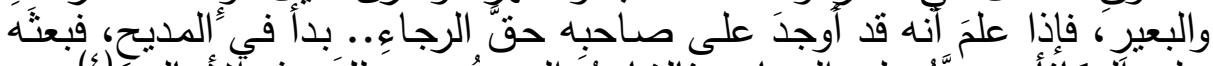

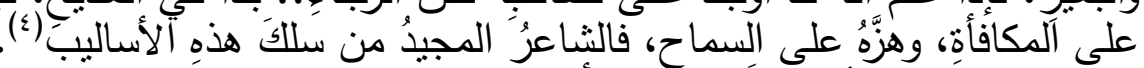

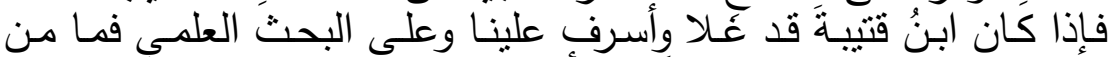

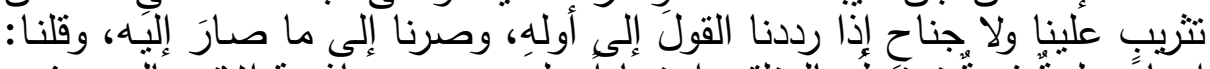

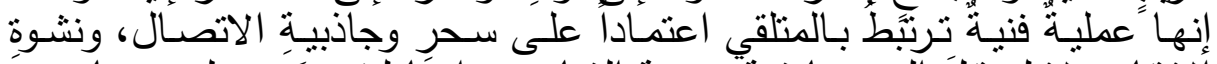

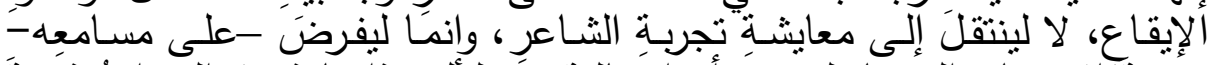

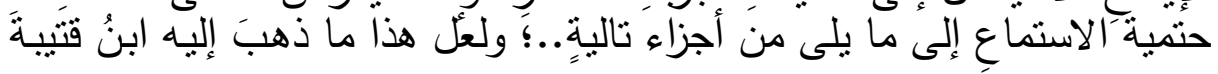

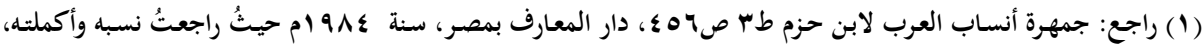

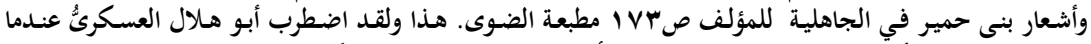

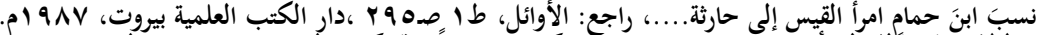

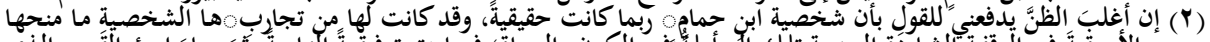

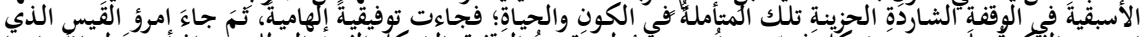

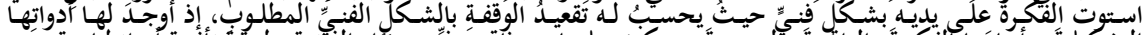

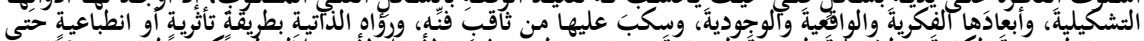

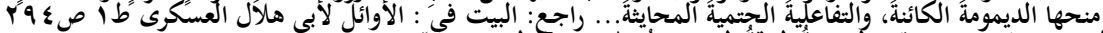

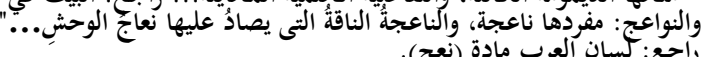




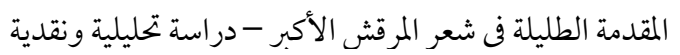

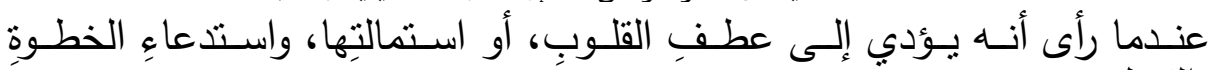

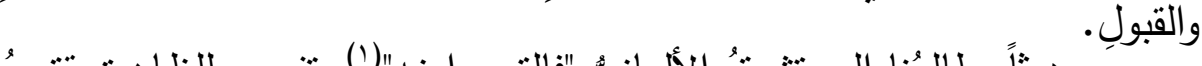

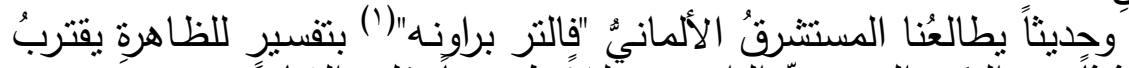

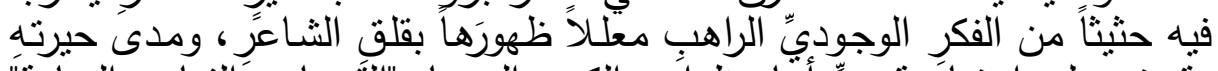

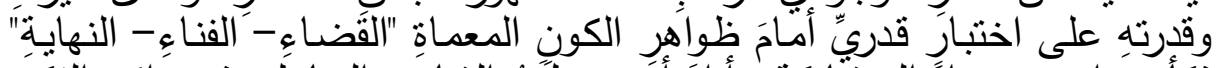

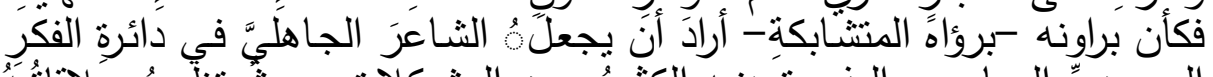

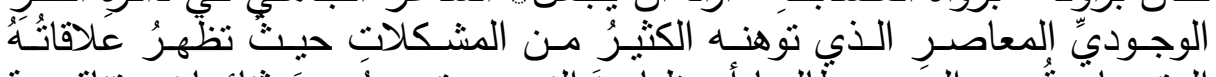

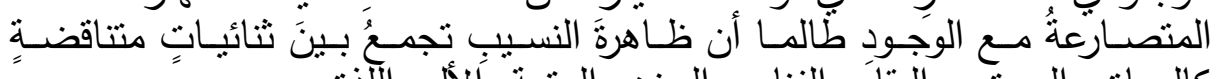

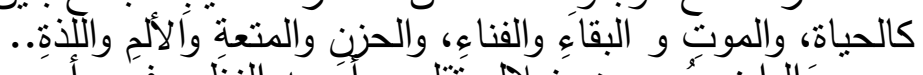

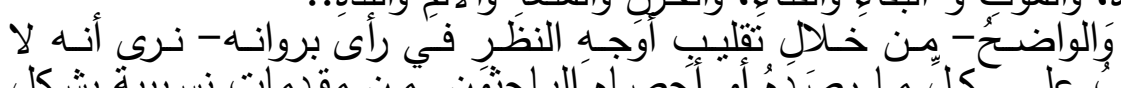

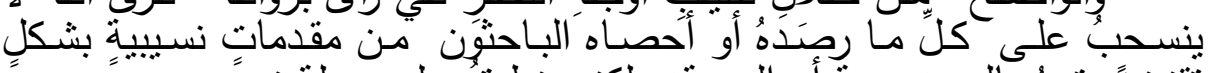

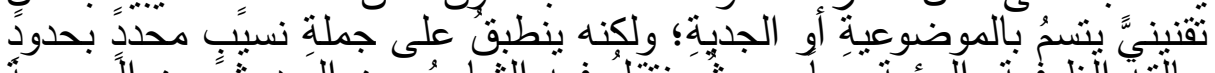

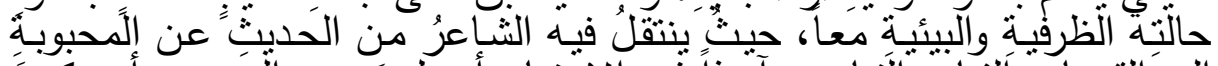

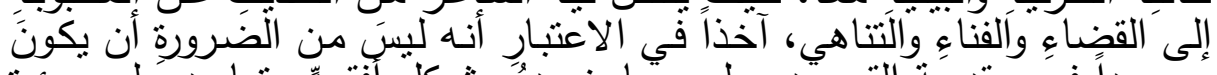

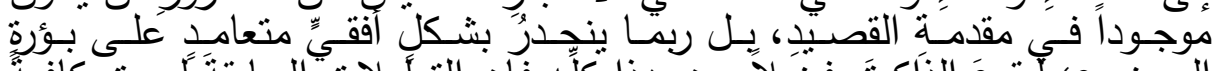

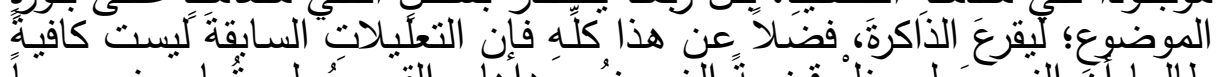

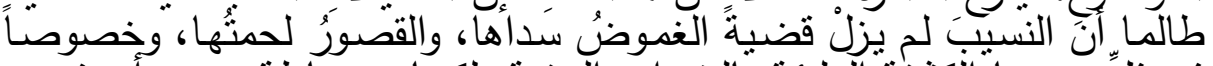

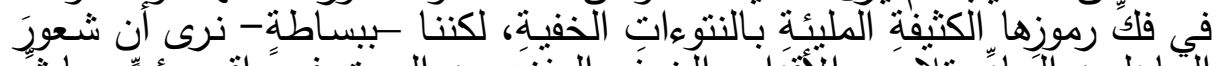

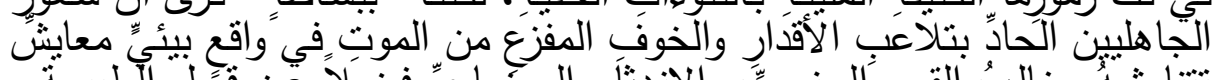

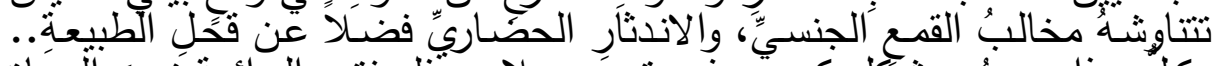

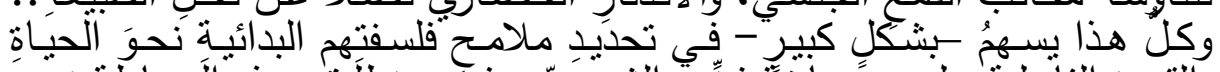

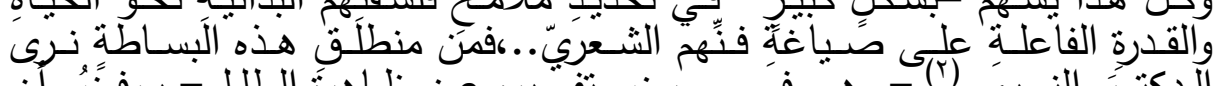

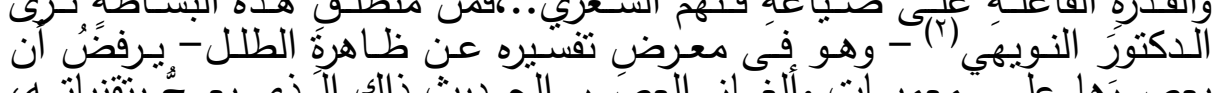

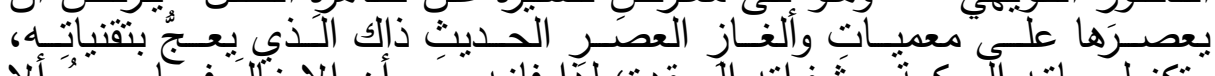

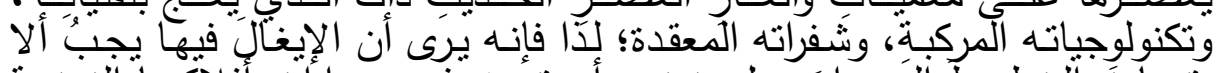

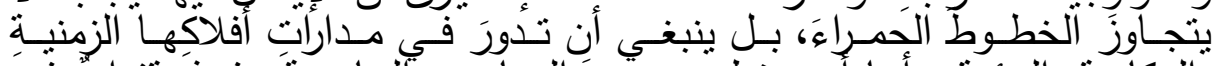

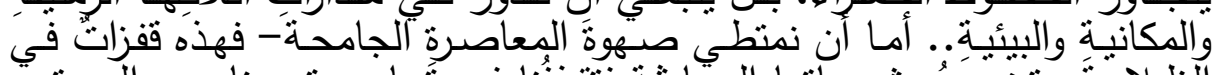

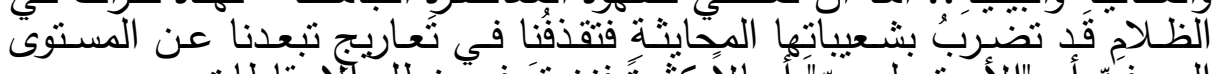

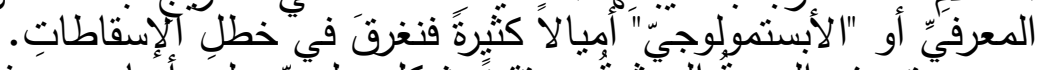

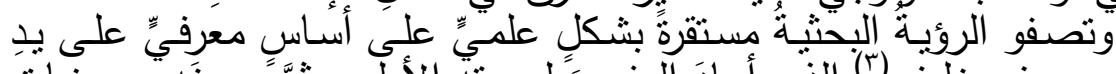

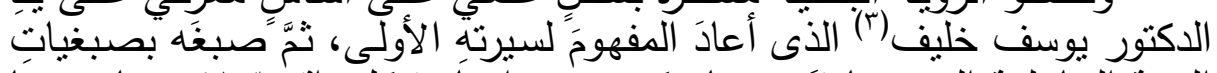

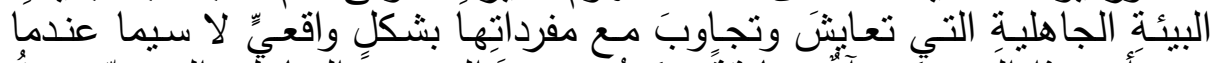

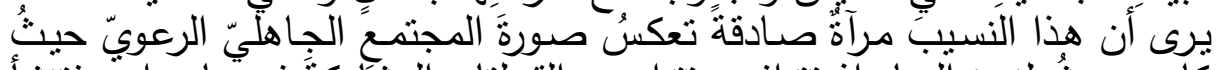

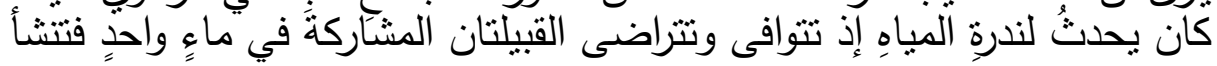




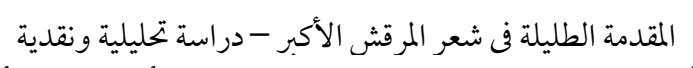

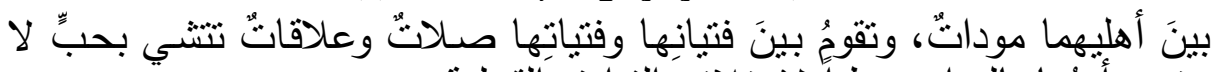

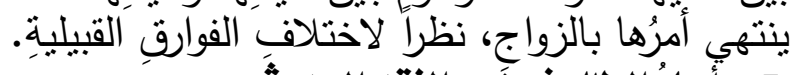

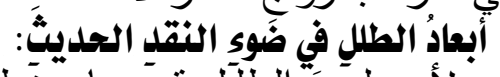

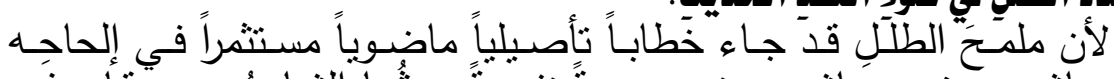

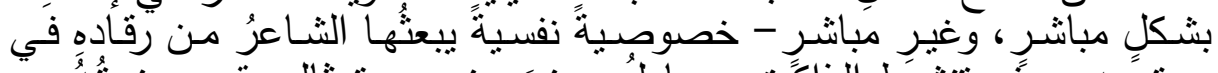

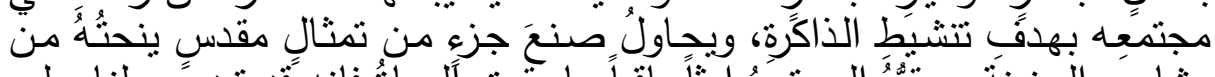

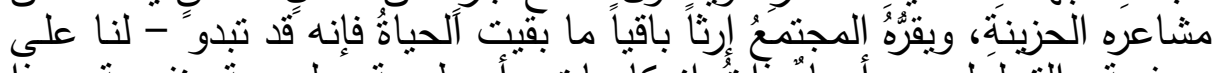

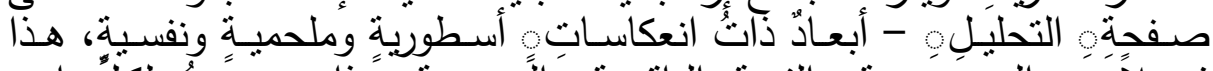

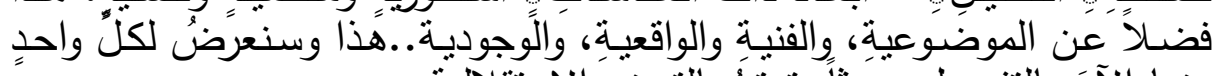

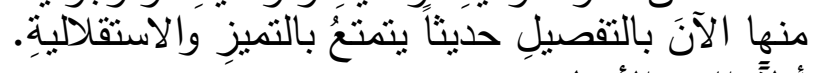

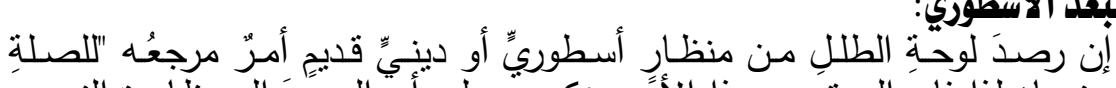

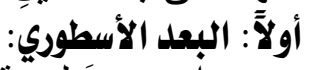

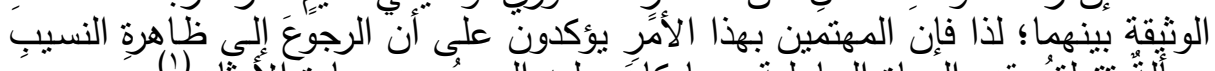

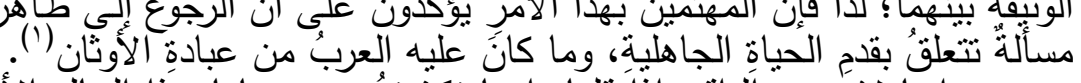

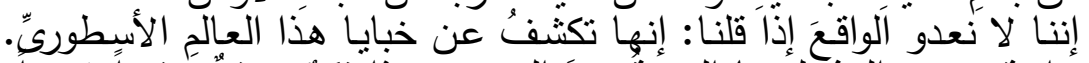

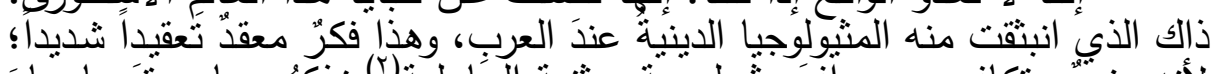

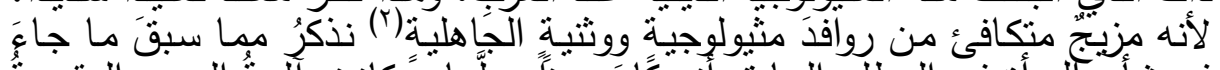

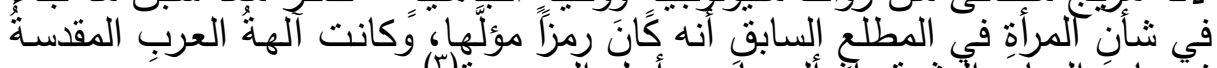

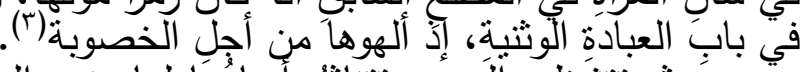

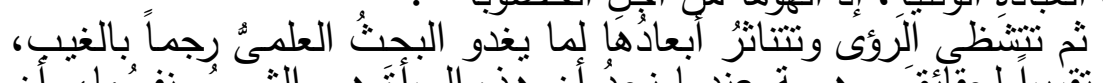

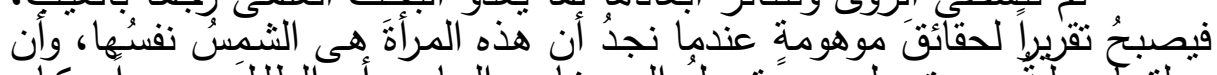

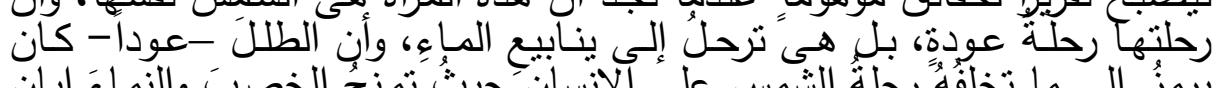

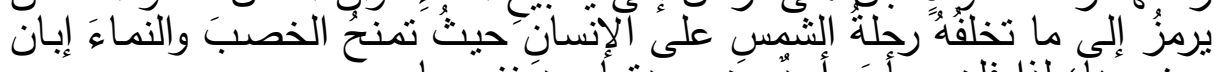

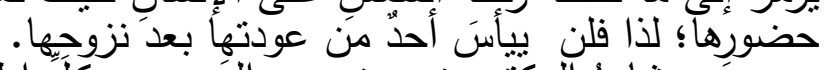

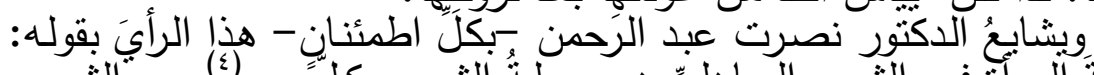

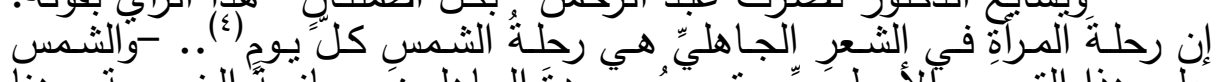

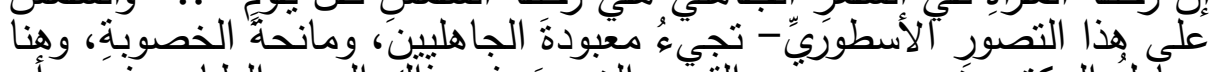

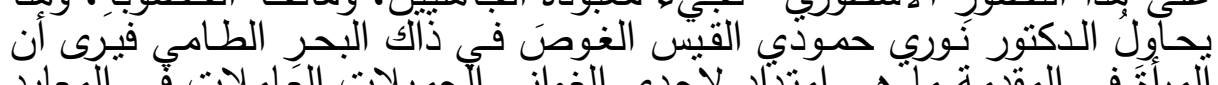

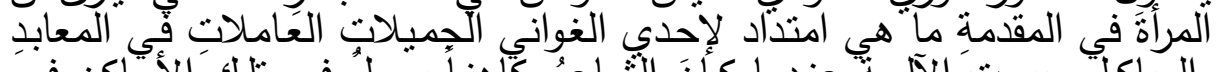

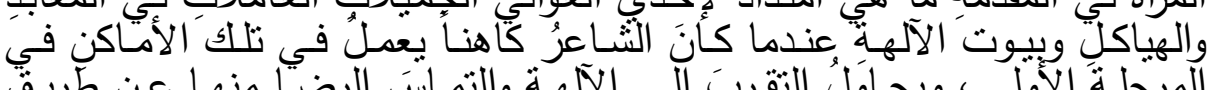

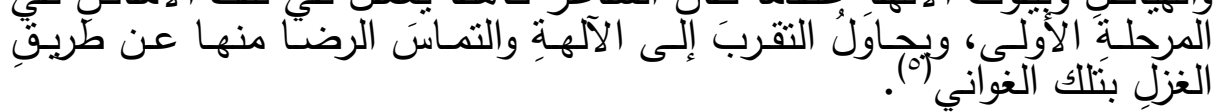

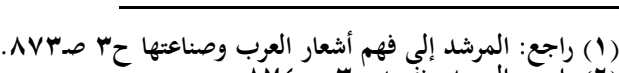

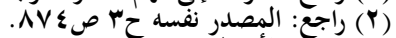

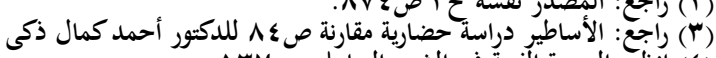

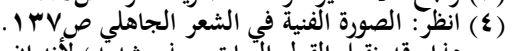

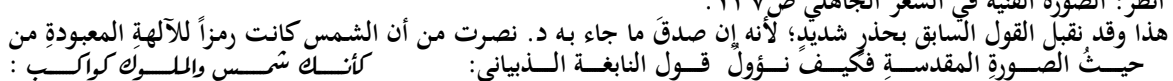

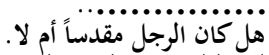

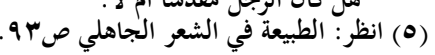




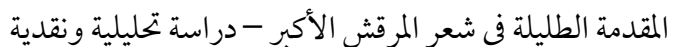

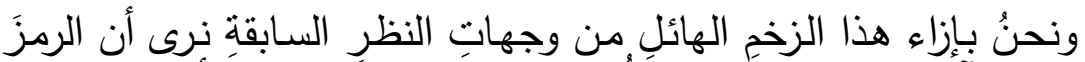

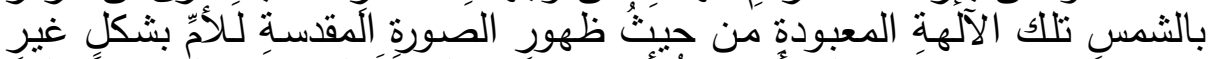

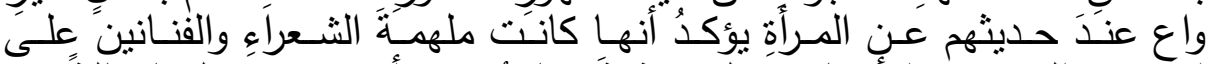

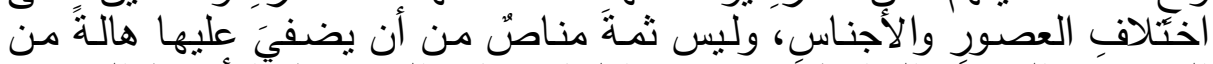

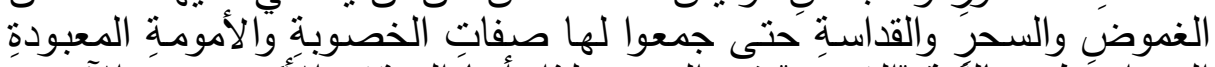

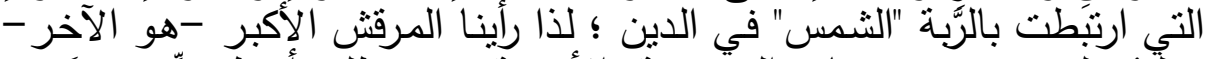

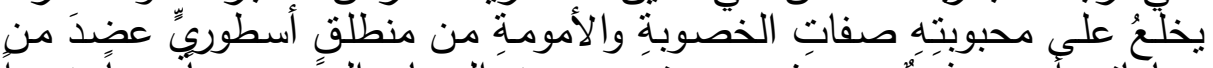

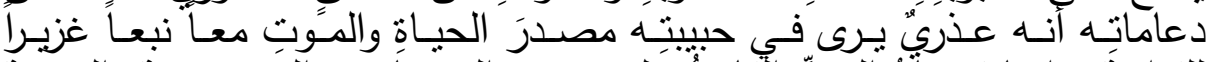

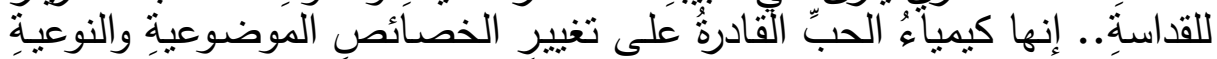

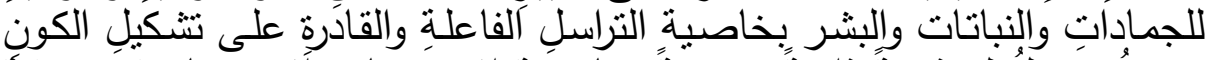

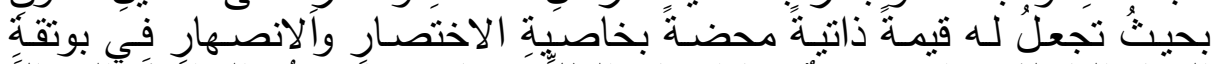

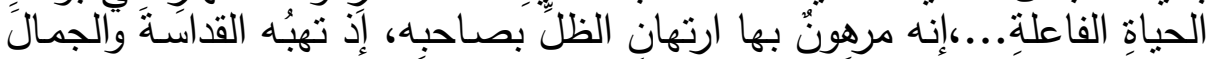

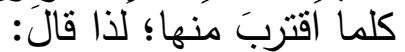

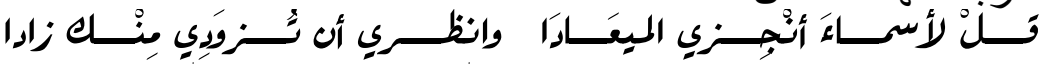

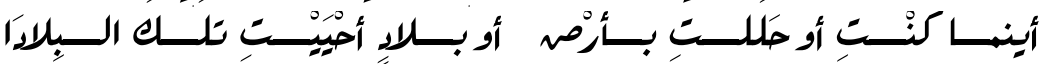

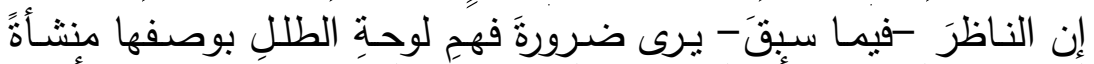

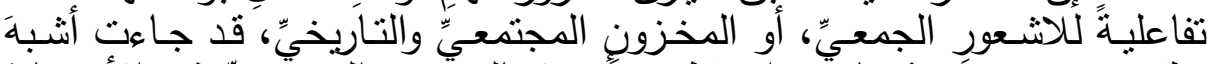

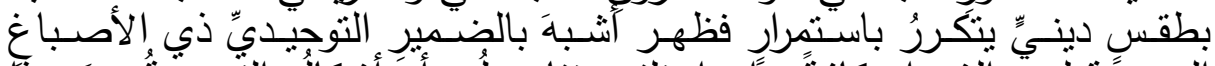

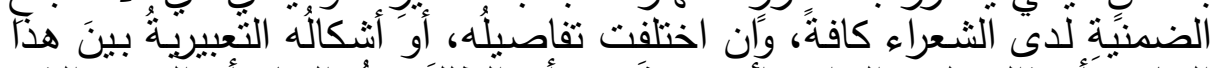

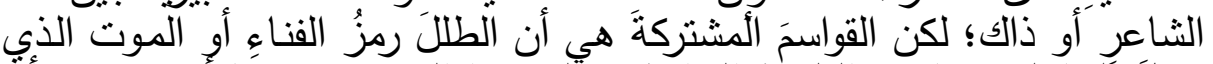

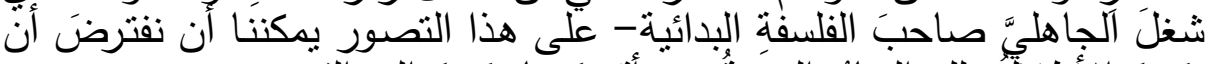

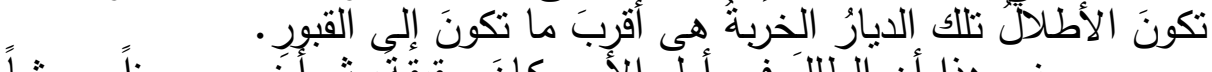

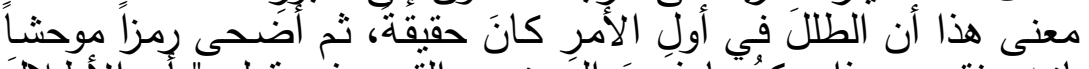

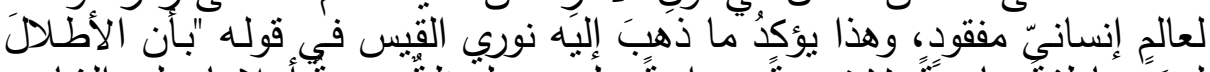

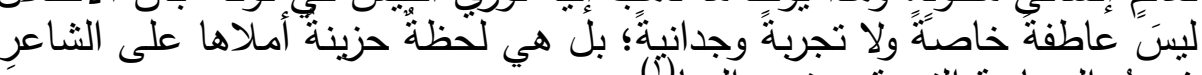

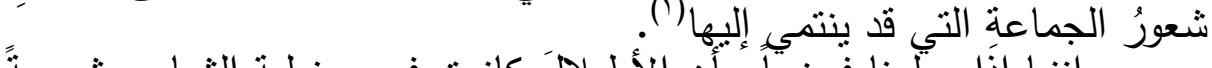

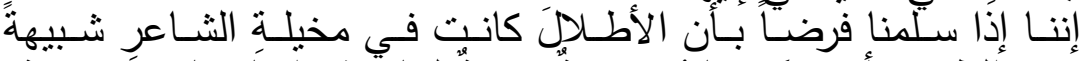

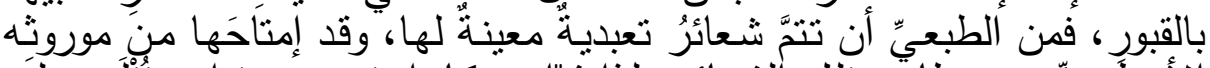

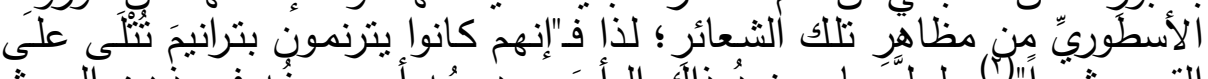

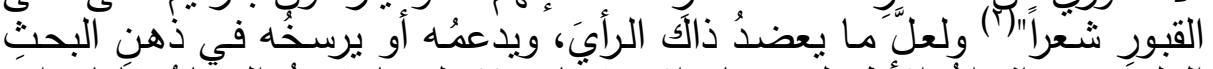

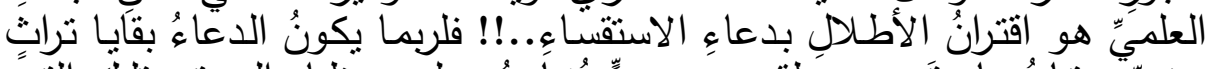

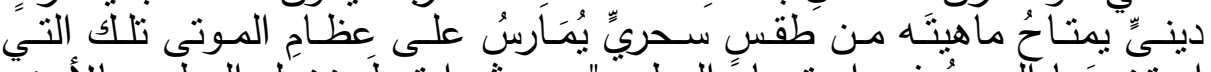

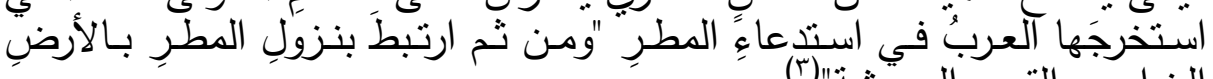

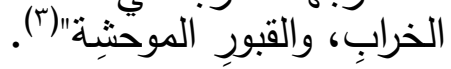




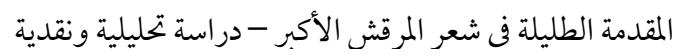

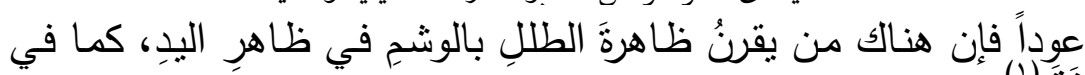

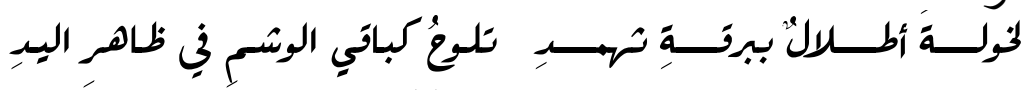

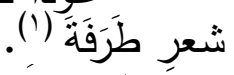

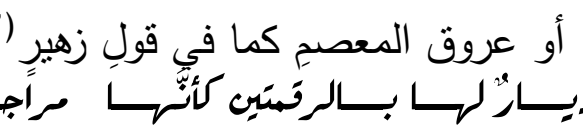

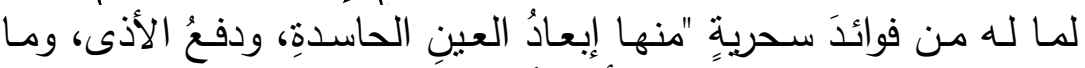

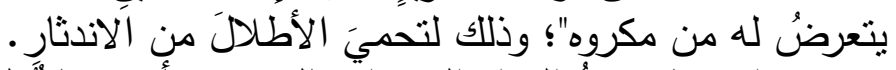

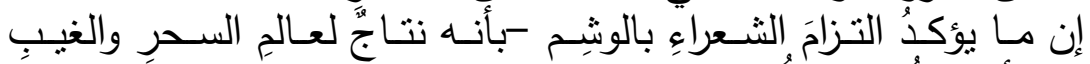

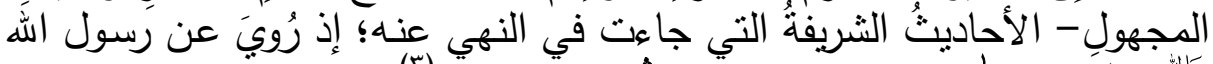

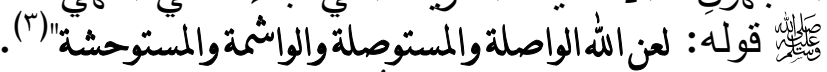

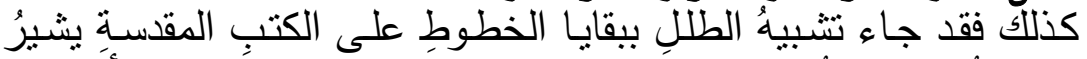

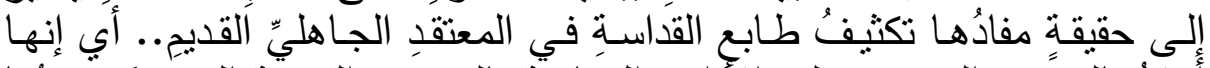

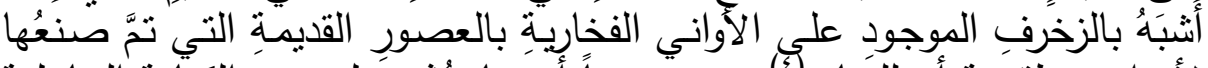

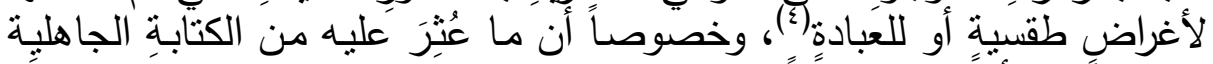

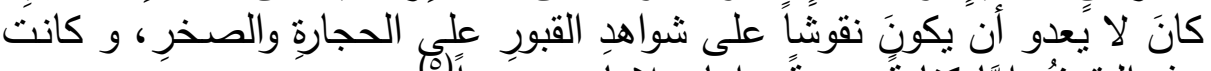

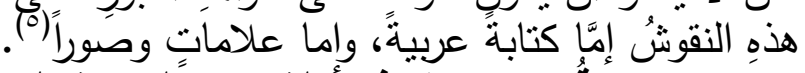

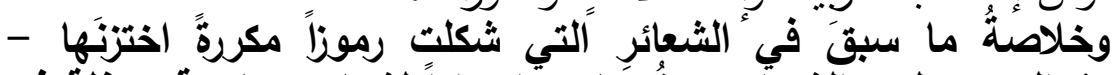

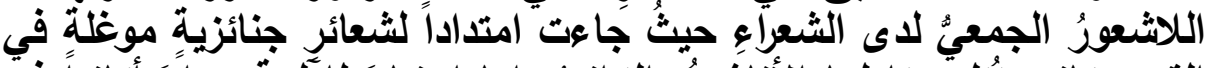

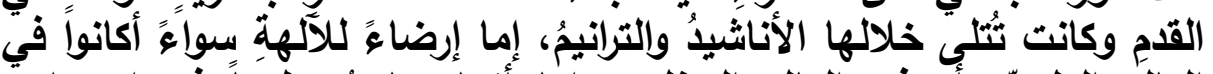

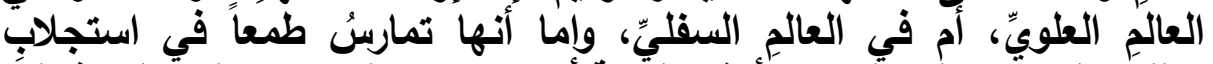

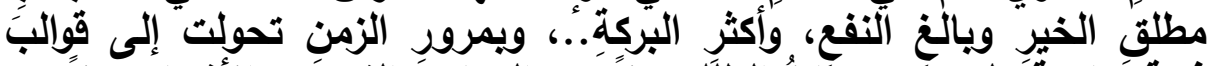

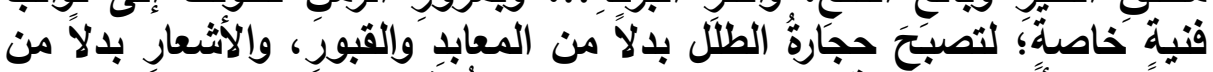

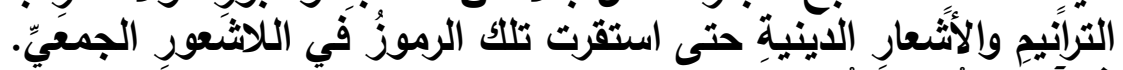

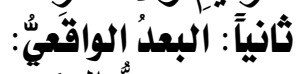

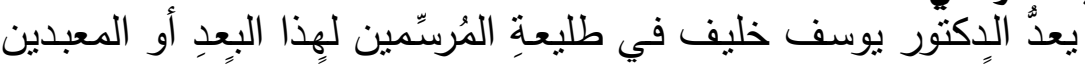

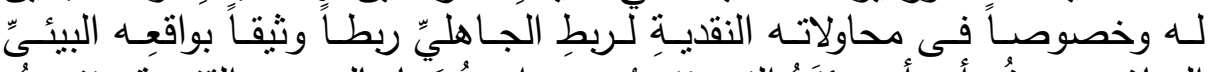

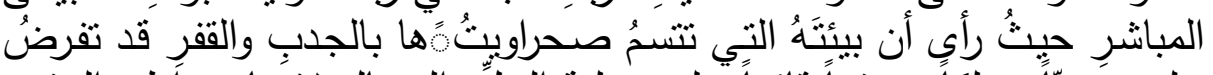

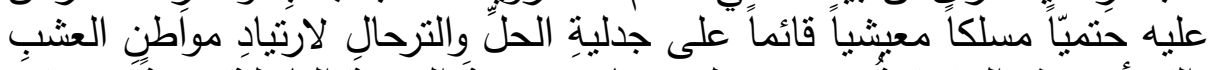

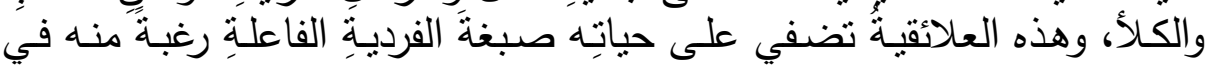

$$
\begin{aligned}
& \text { (1) انظر : شرح القصائد السبع الطوال الجاهليات للأنباري طه، ص ب آ. }
\end{aligned}
$$

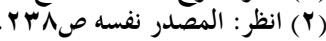

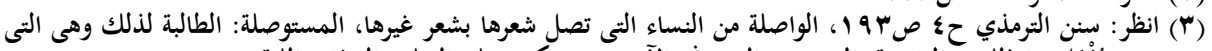

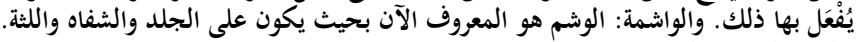




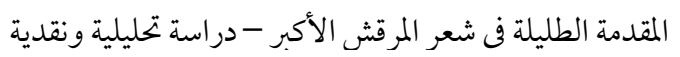

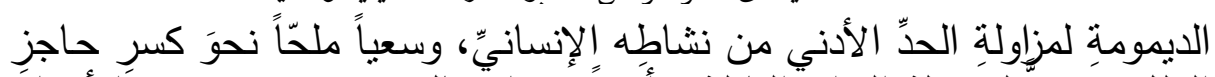

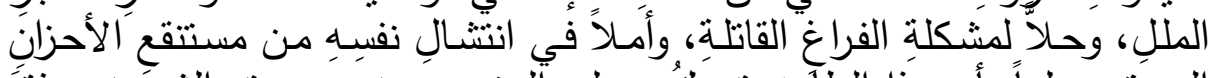

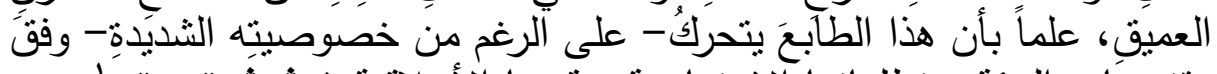

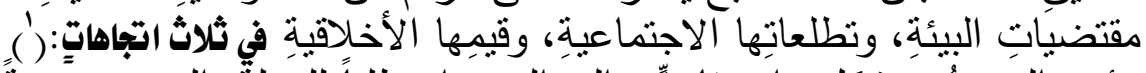

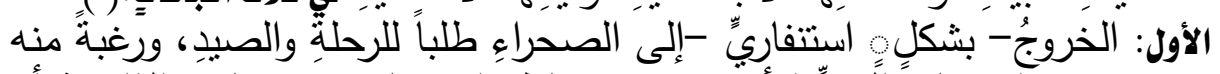

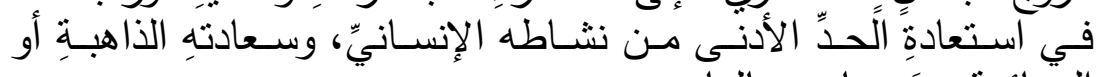

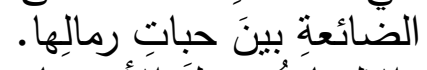

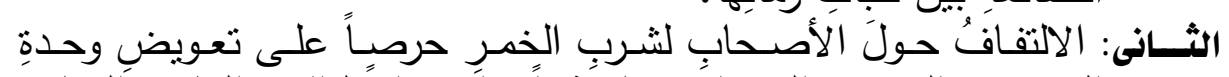

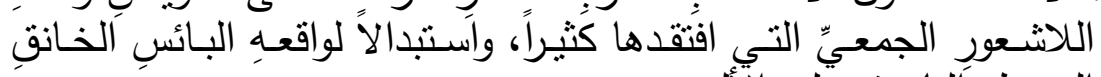

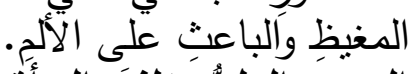

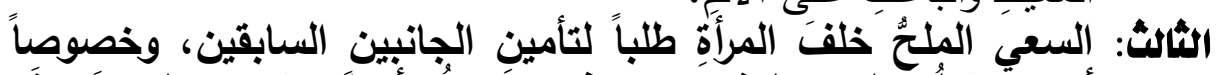

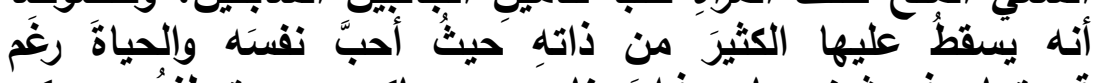

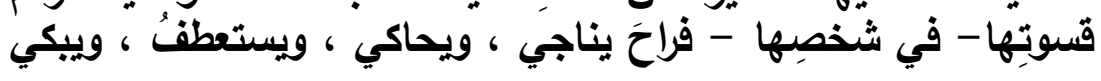

ويطلبُ الصفحَ والغفران....

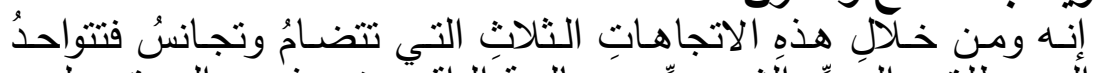

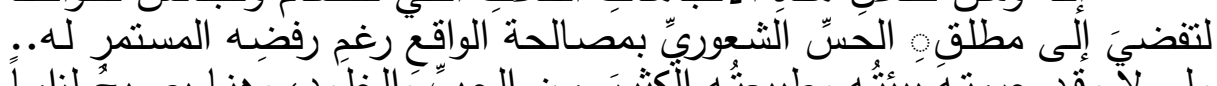

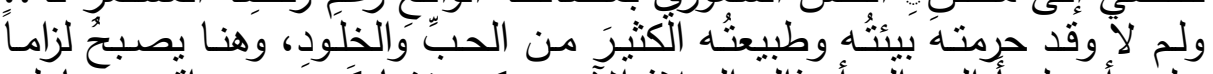

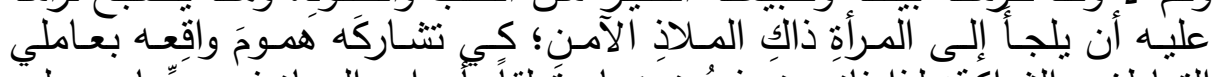

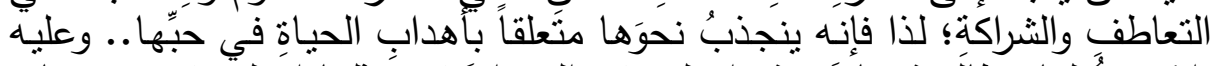

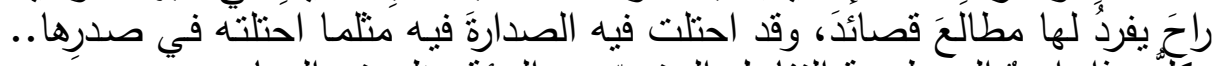

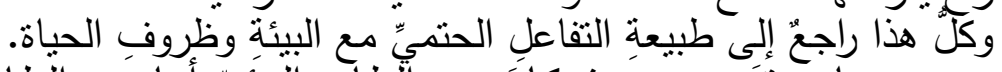

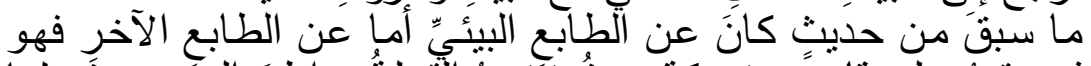

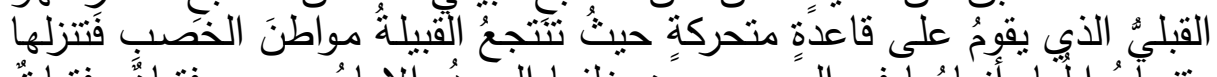

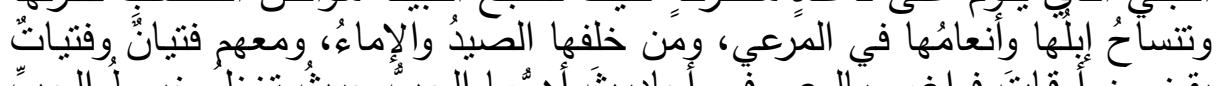

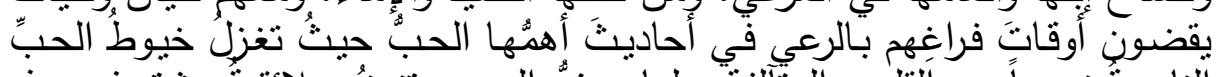

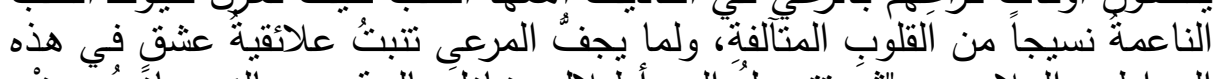

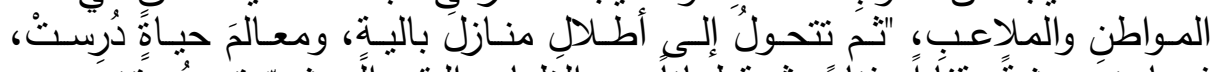

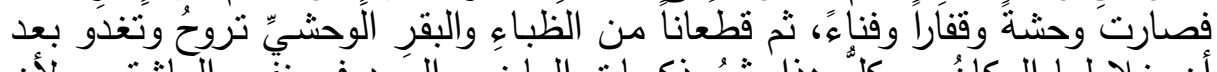

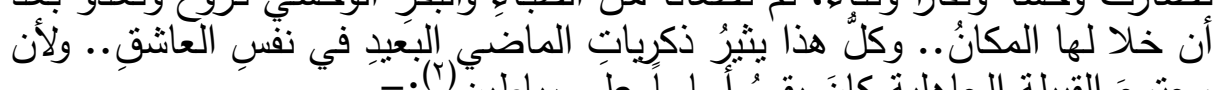

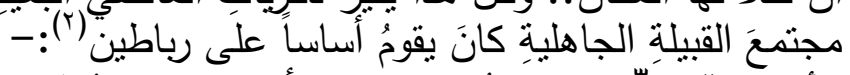

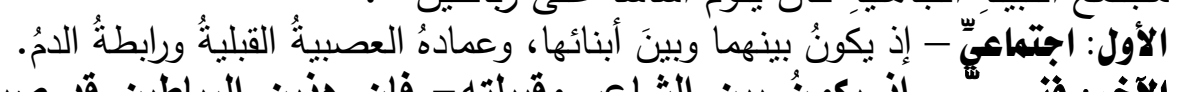

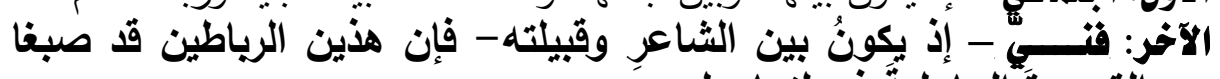

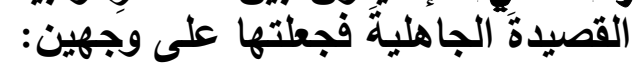




\section{المقدمة الطليلة فى شعر المرقش الأكبر - دراسة تحليلية ونقدية}

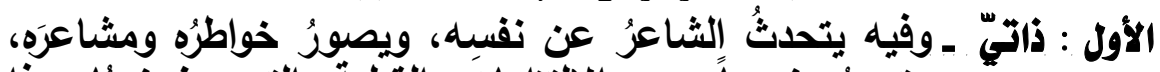

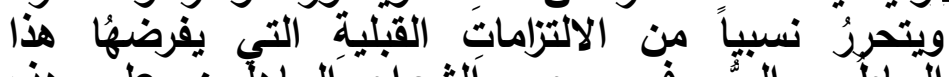

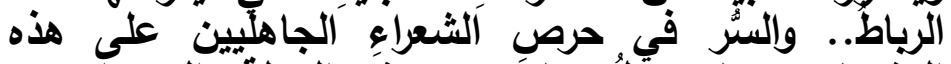

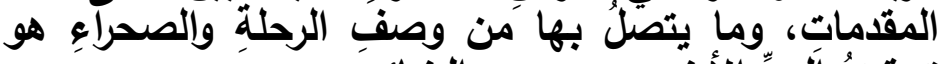

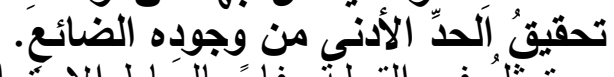

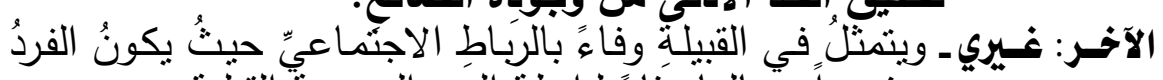

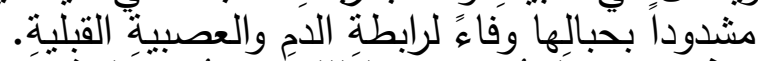

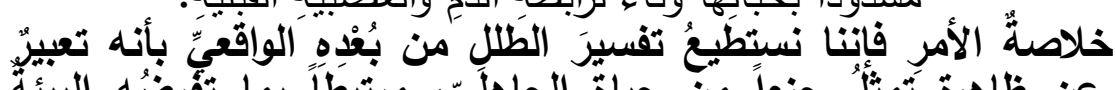

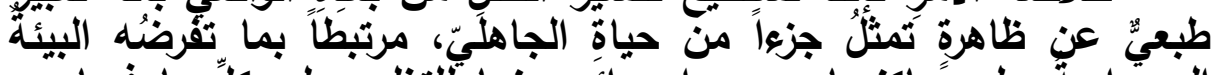

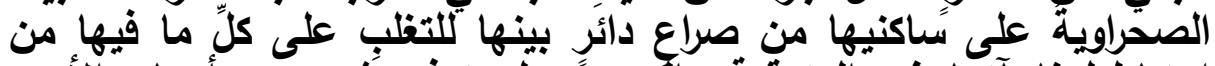

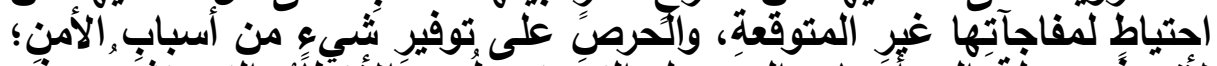

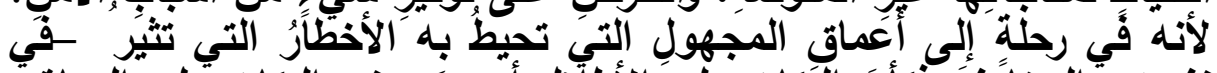

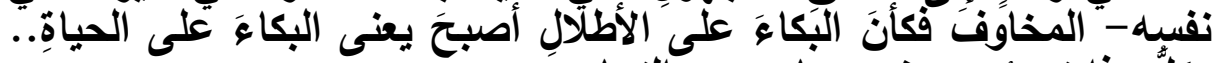

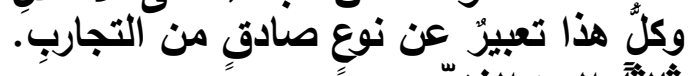

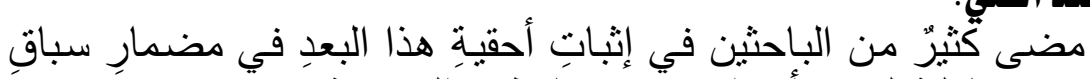

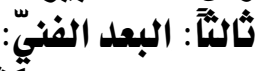

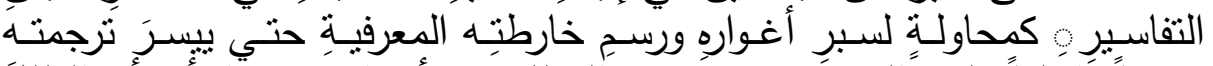

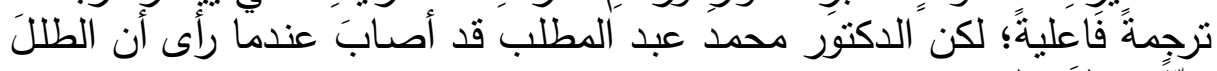

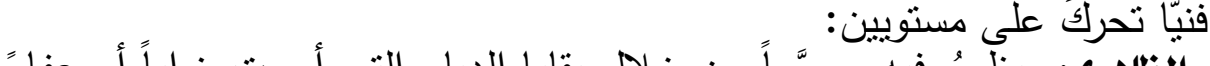

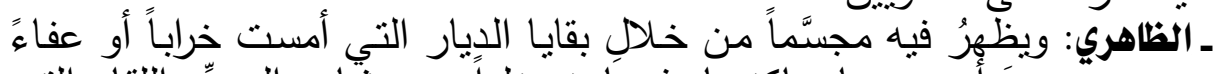

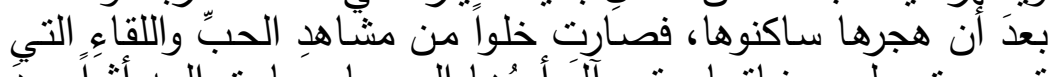

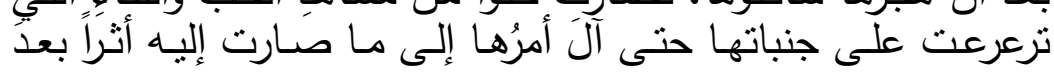

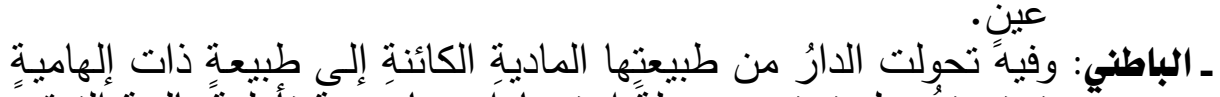

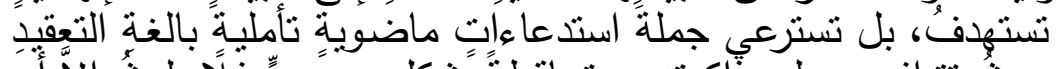

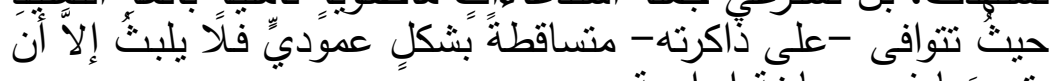

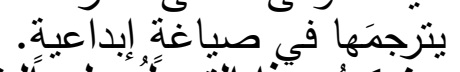

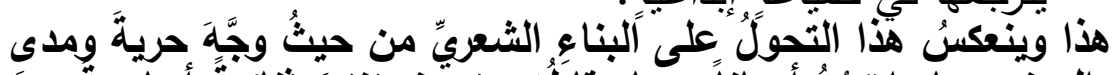

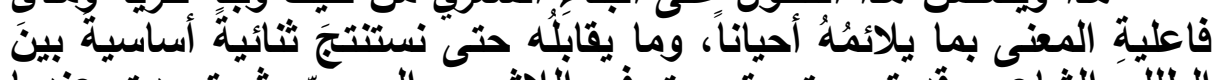

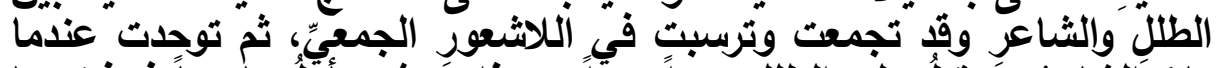

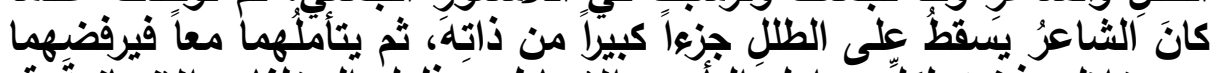

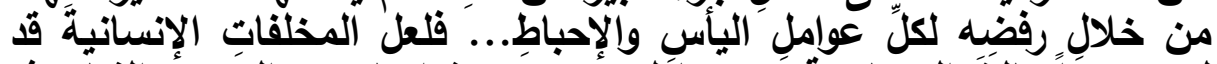

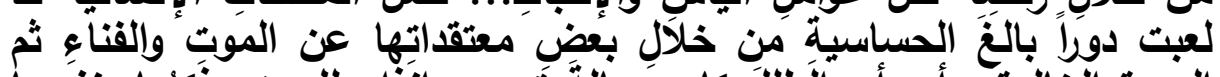

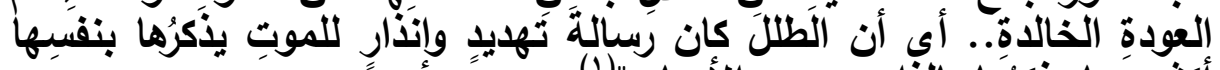

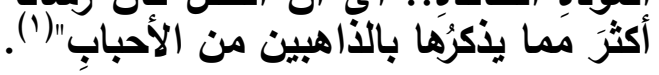




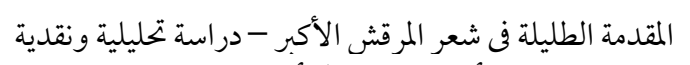

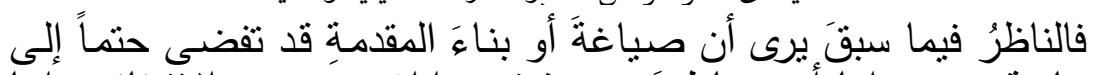

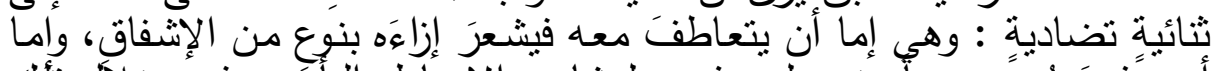

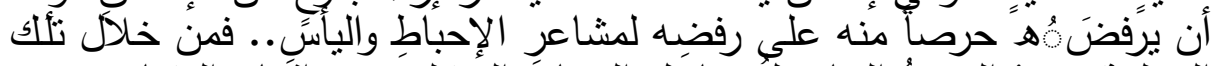

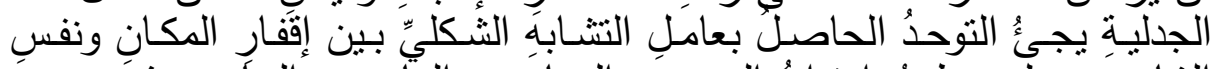

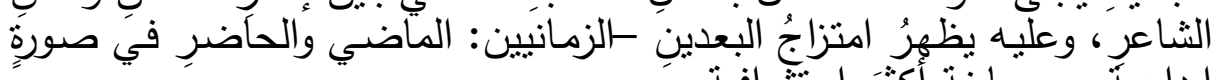

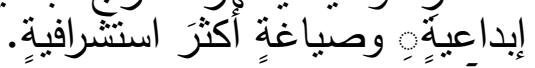

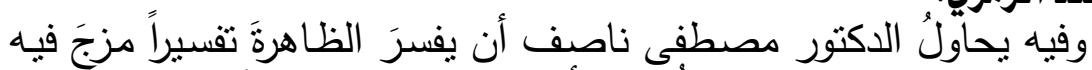

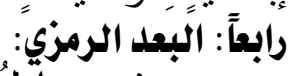

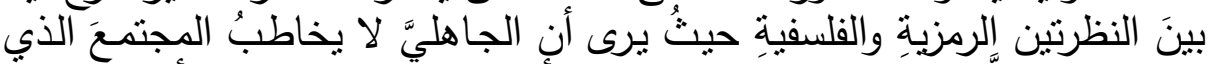

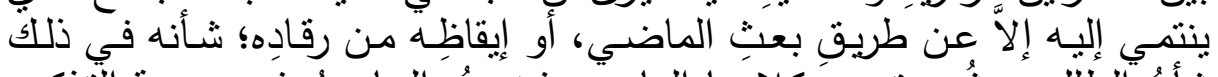

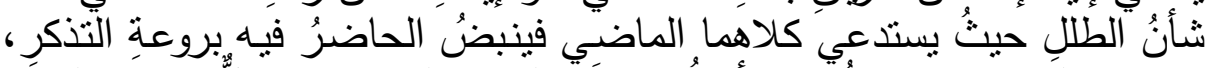

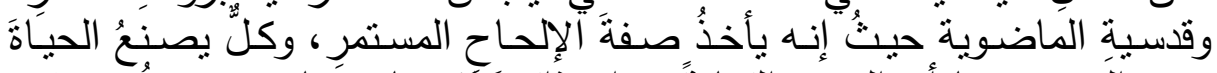

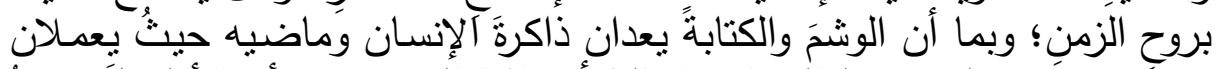

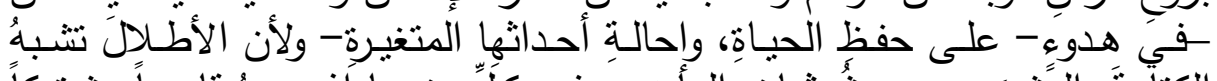

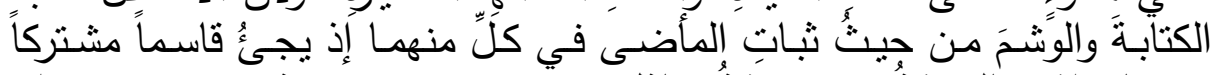

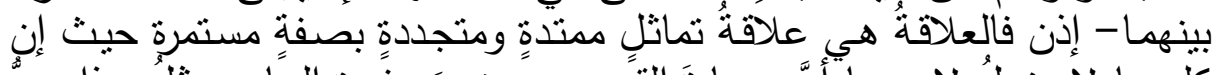

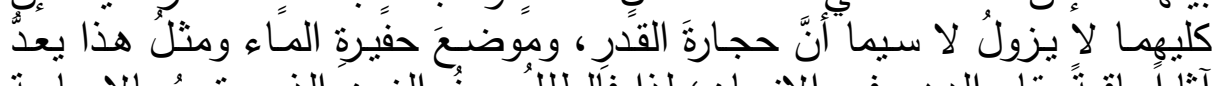

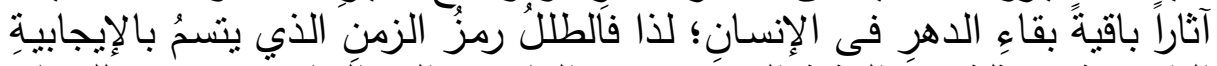

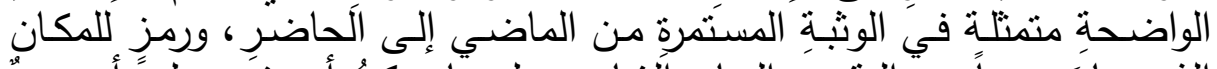

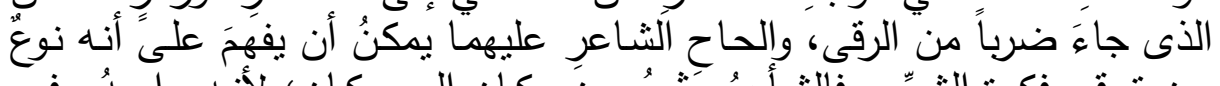

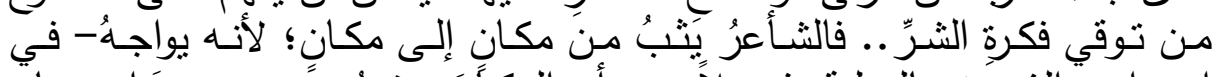

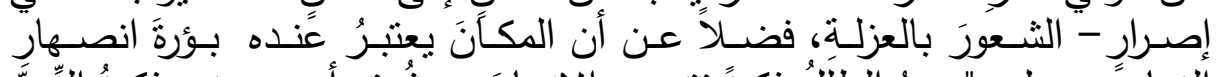

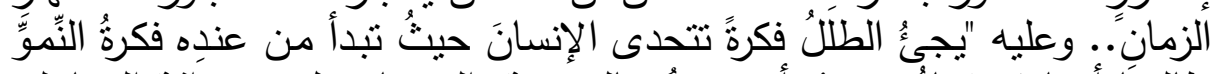

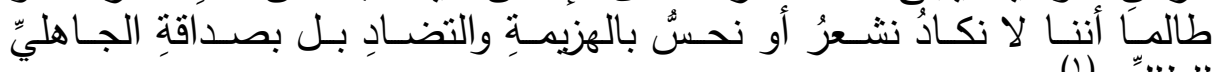

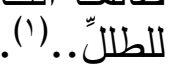

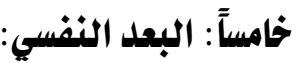

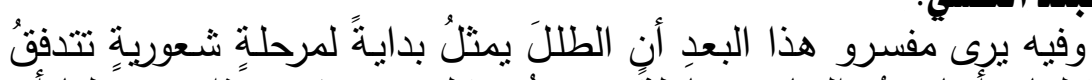

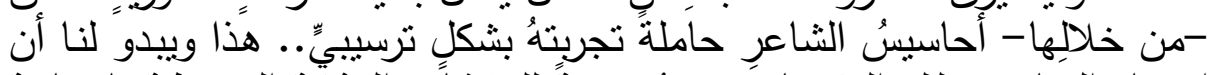

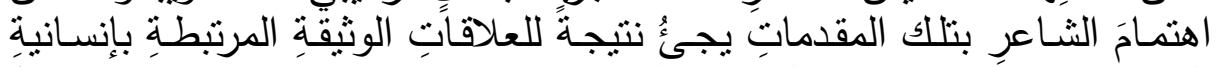

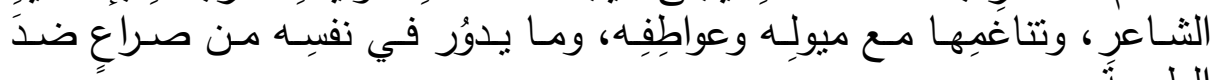
الطبيعةً.

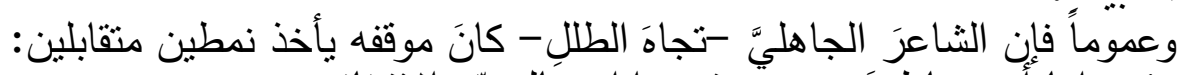

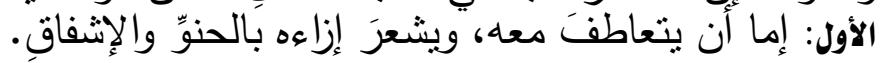




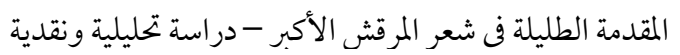

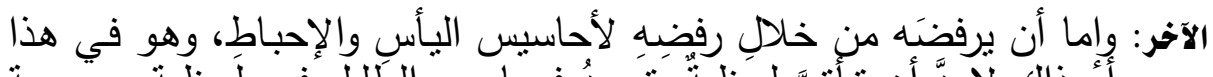

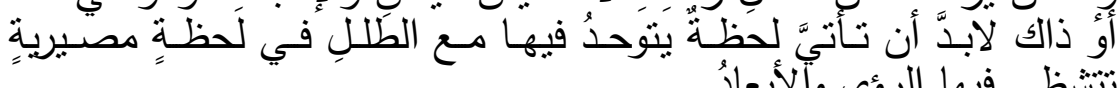

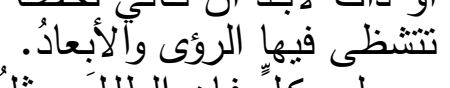

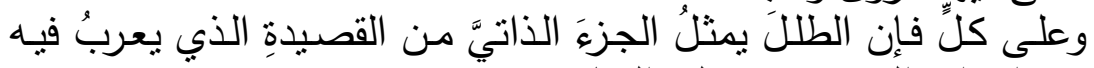

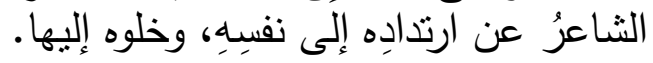

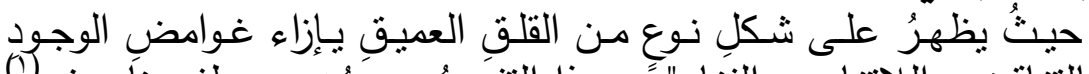

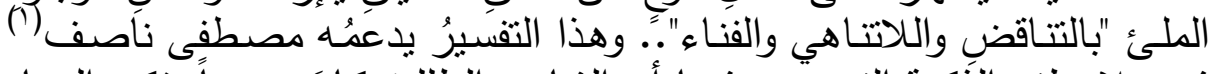

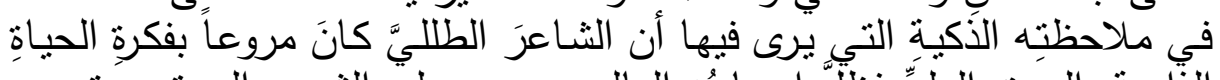

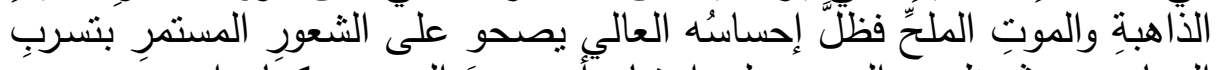

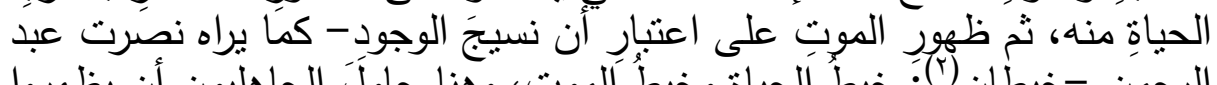

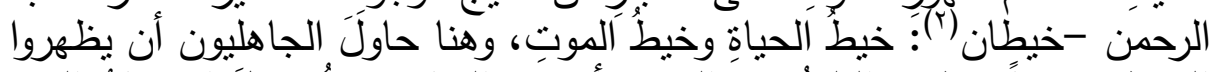

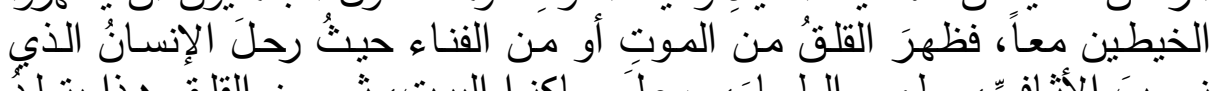

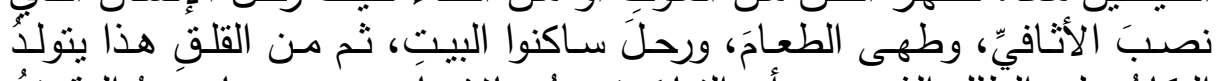

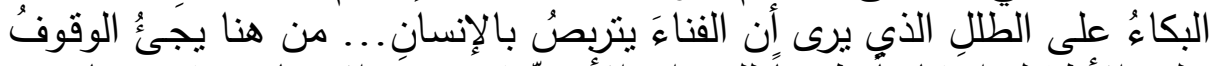

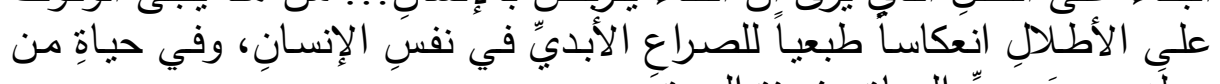

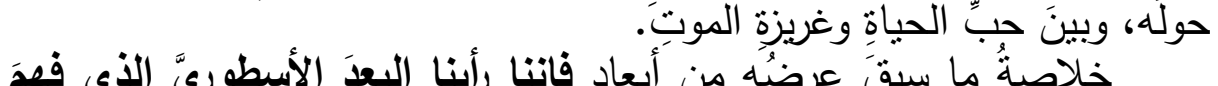

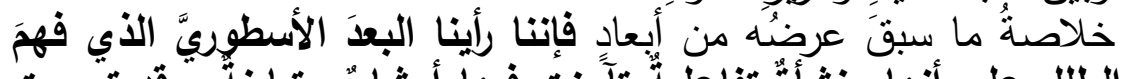

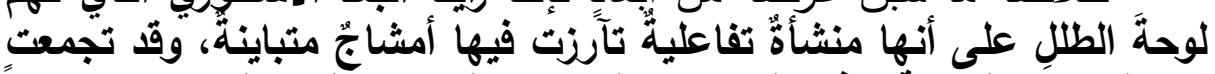

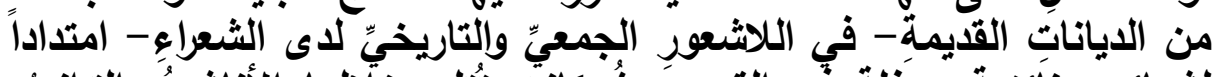

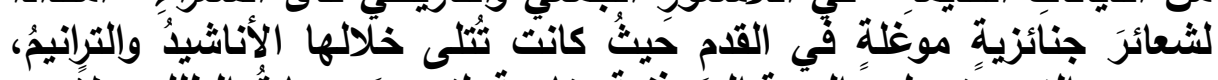

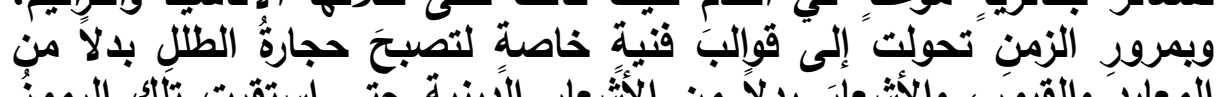

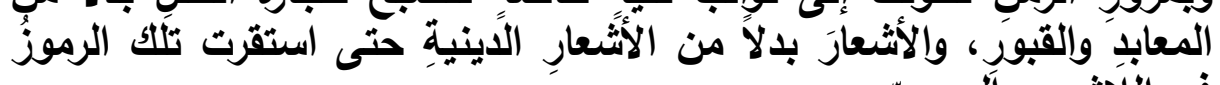

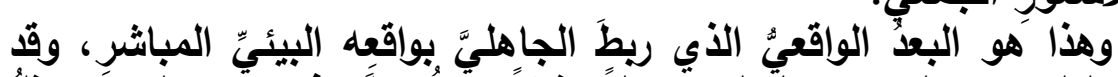

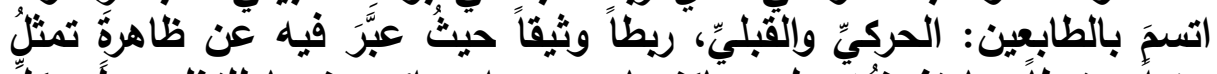

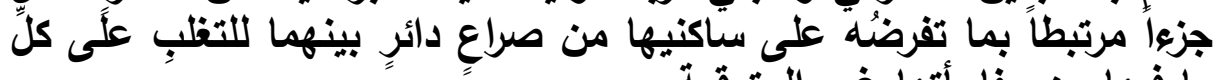

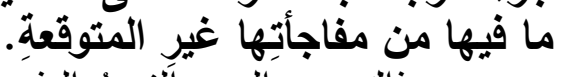

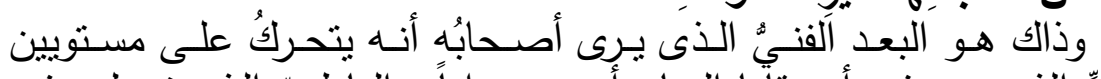

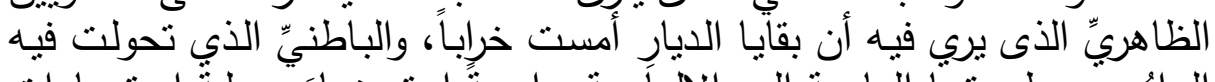

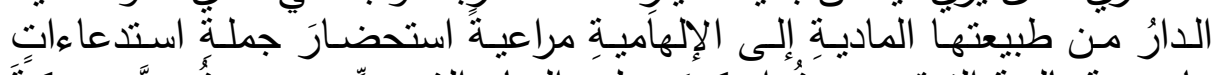

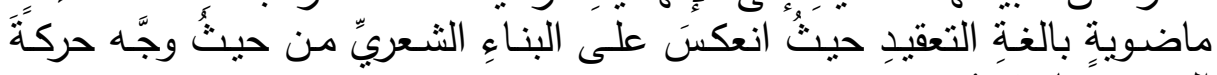

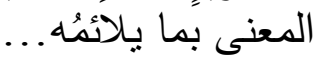




\section{المقدمة الطليلة فى شعر المرقش الأكبر - دراسة تحليلية ونقدية}

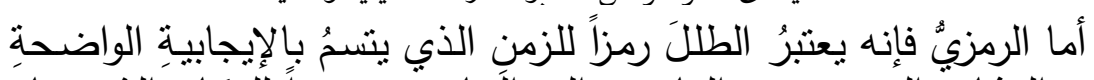

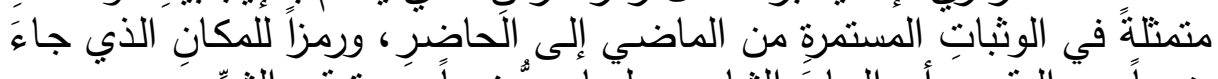

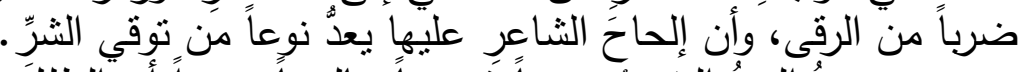

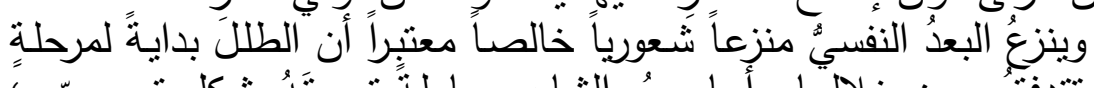

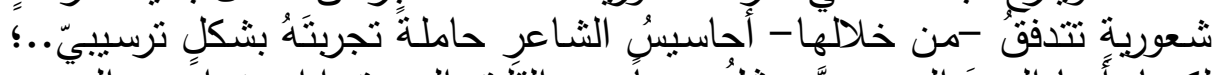

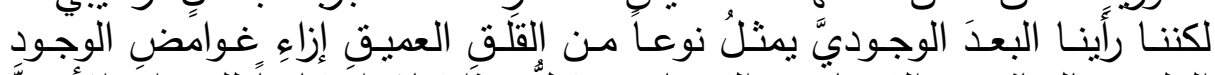

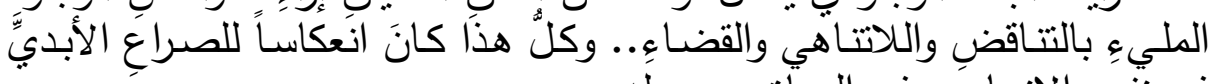

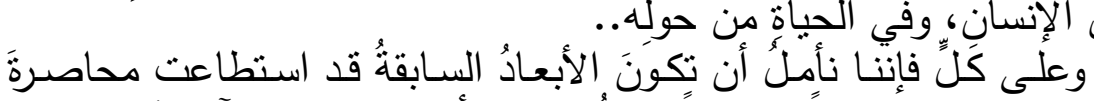

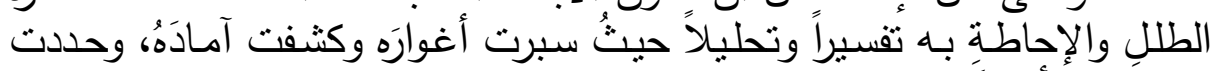

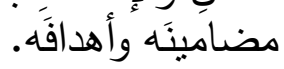


ב = المجلد الأول من العدد الخامس والعثرين لحولية كلية الاراسات الإسلامية والعربية للبنات ـ بالإسكندرية ع

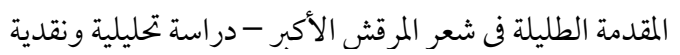

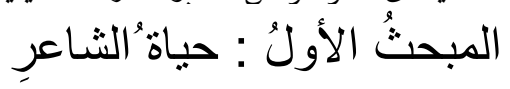

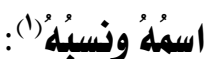

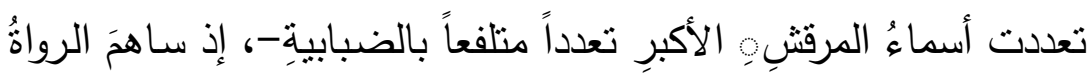

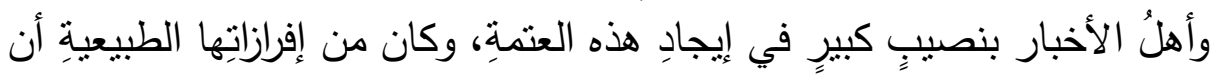

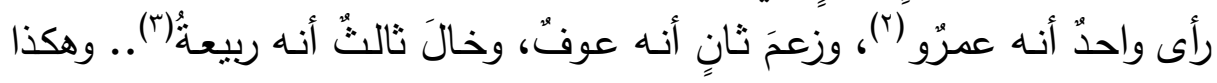

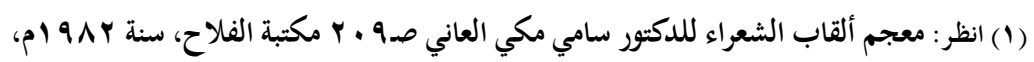

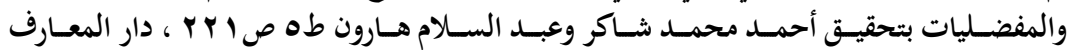

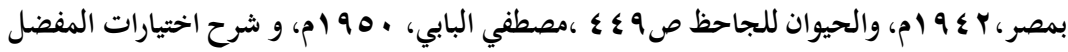

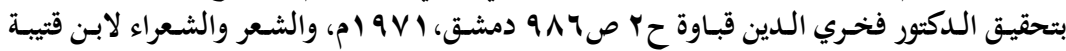

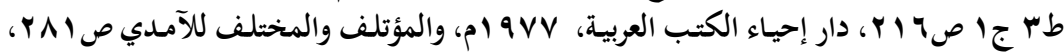

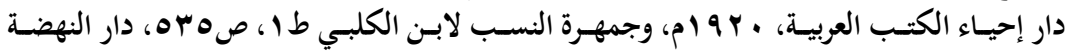

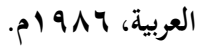

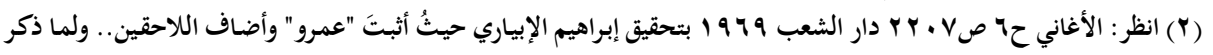

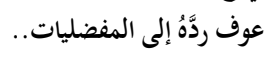

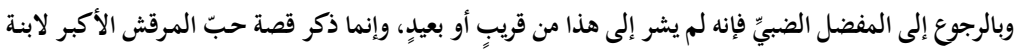

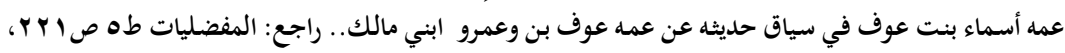

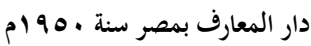

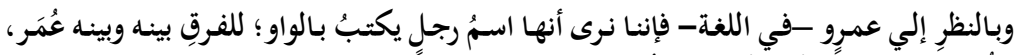

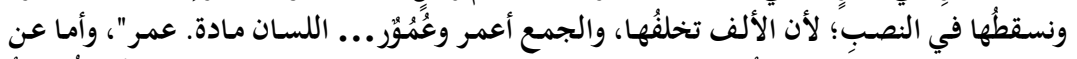

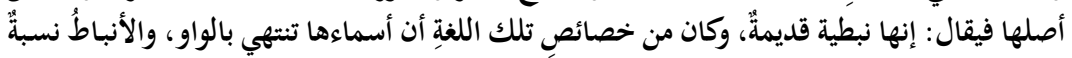

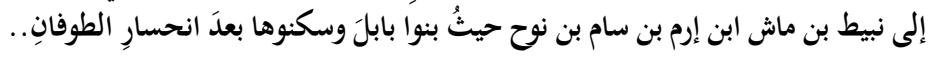

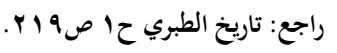

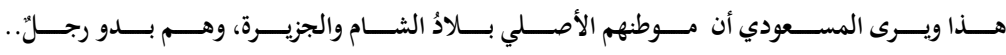

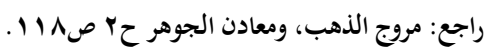

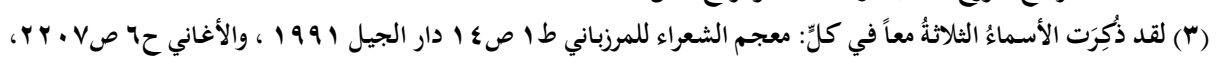

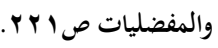

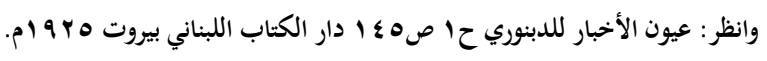

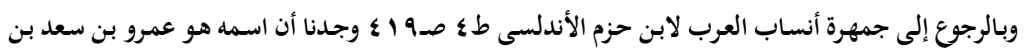

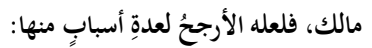

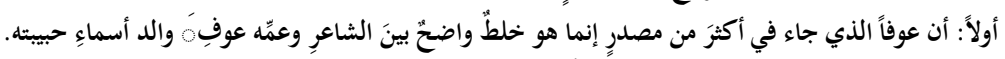

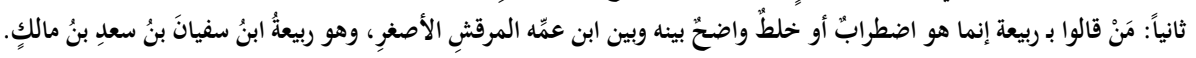

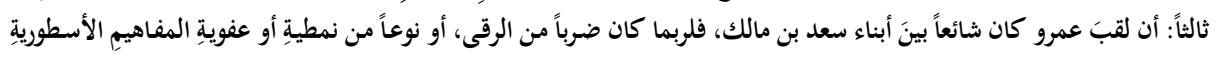

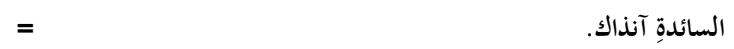

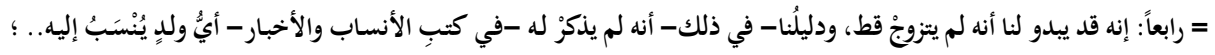

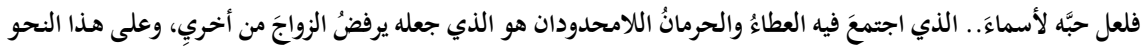




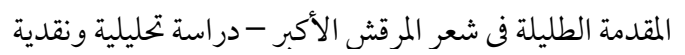

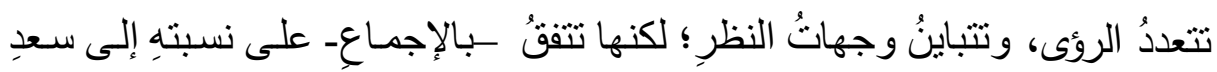

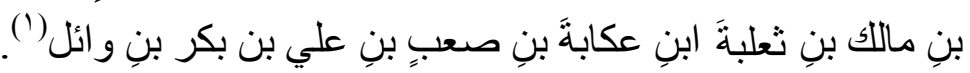

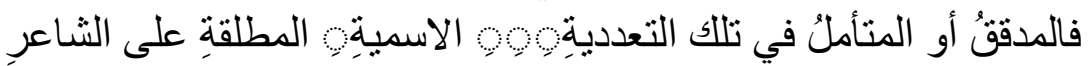

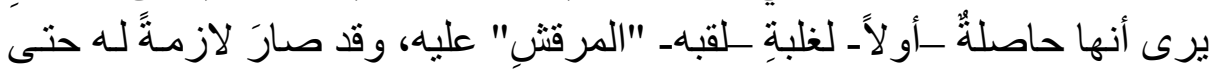

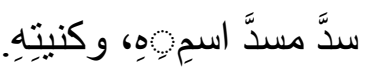

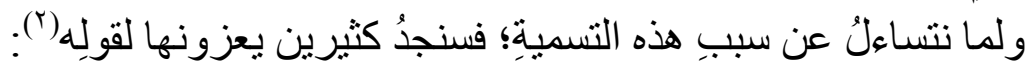

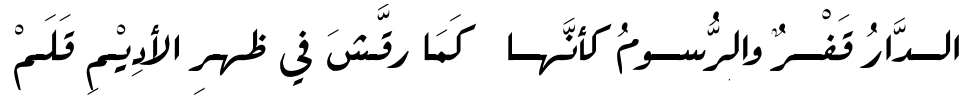

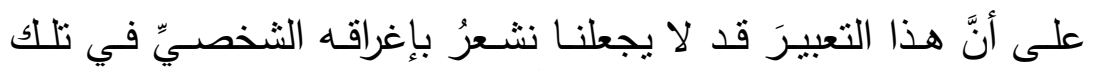

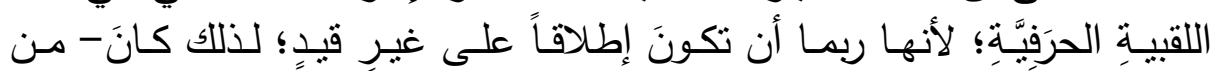

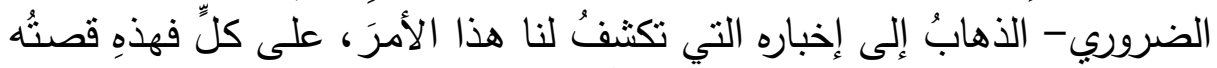

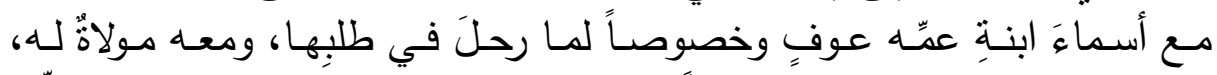

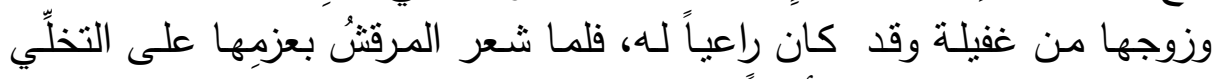

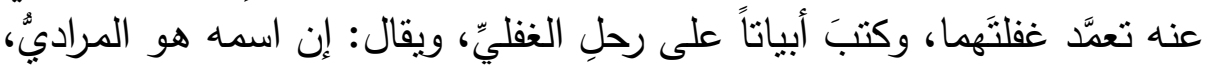

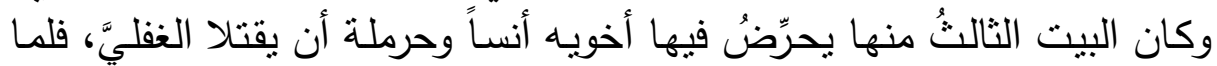

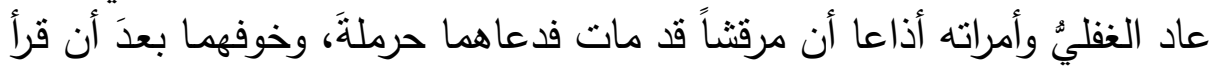

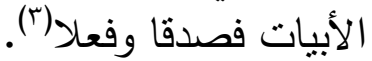

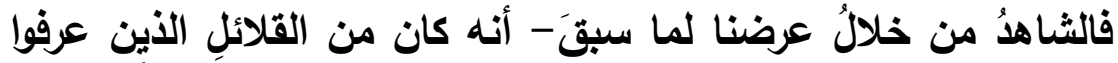

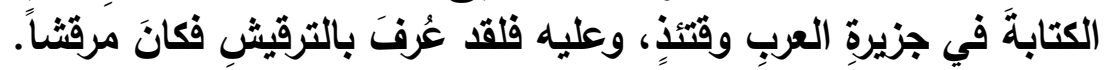

فِإنه ليس له ولدُ يخلدُ اسمَه، بأن يذيعَه بينَ الناسِ فيرسخَ في الأذهانِ لا سيما أنه كان معروفاً أو مشهوراً بينَ القبائلِ في عصره.

خامساً: أن البعدَ الزمنيَّ بينَه وبينَ المؤرخين ربما كانَ سبباً من أسبابِ هذا الاضطرابِ الحاصلِ في اسمه.

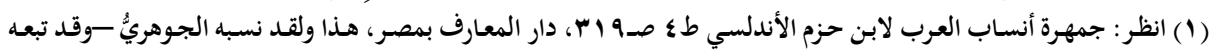

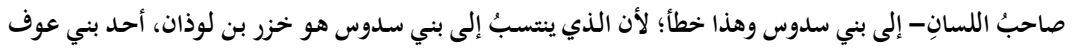

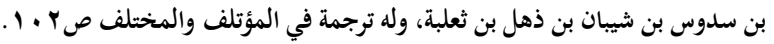

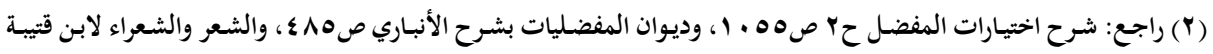

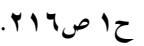

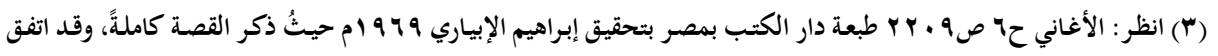

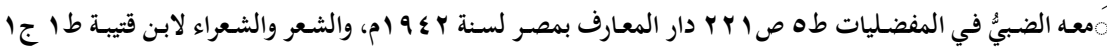




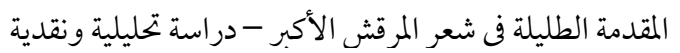

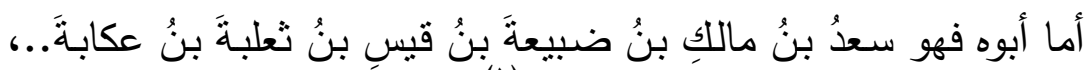

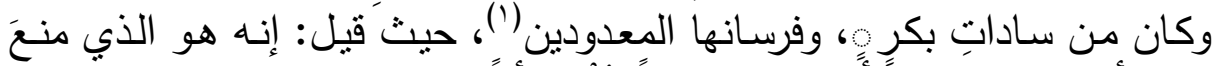

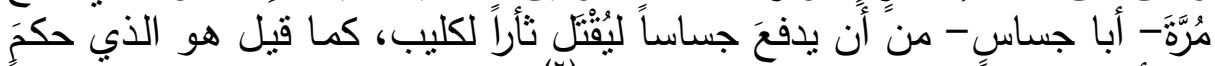

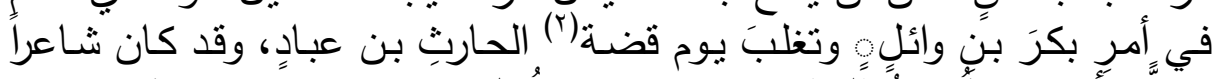

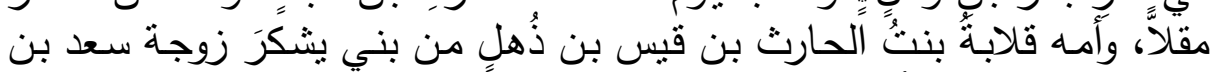

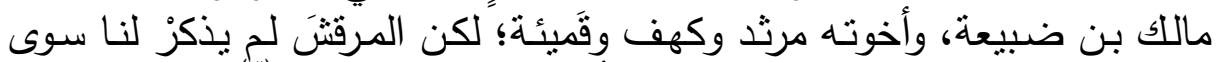

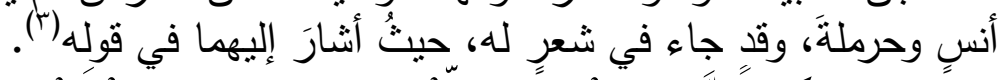

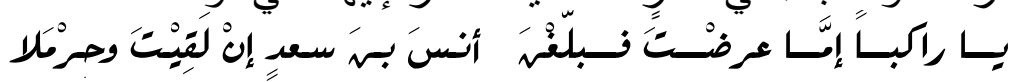

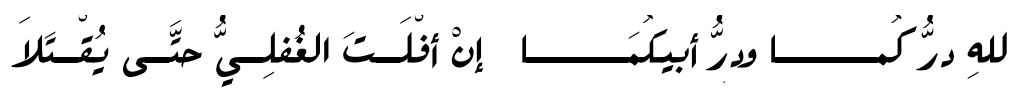

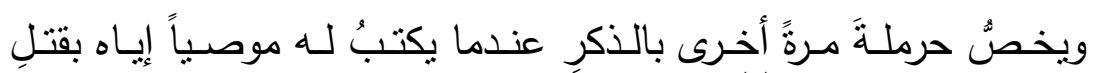

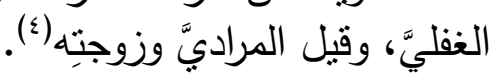

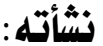

قد نجدُ من الصعوبة -بمكان - تحديدَ إقامةِ المرقش الأكبر وذلك لأمرين:

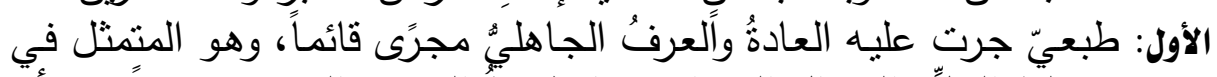

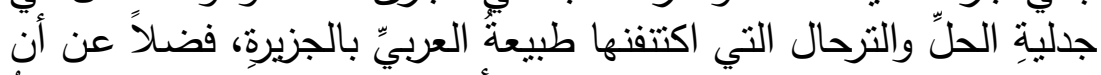

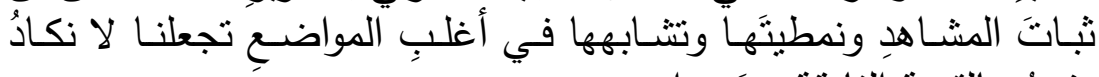

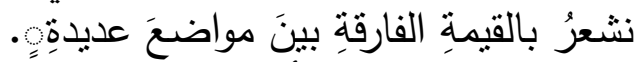

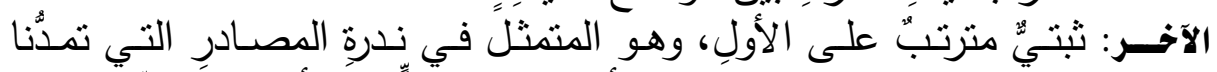

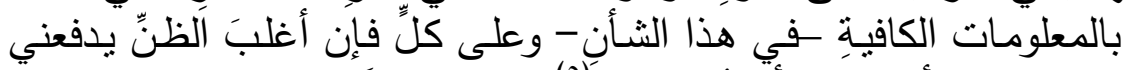

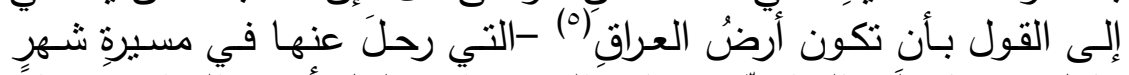

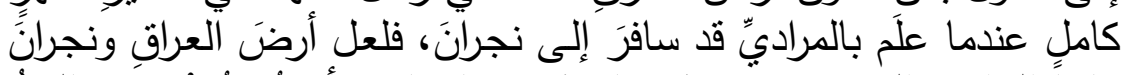

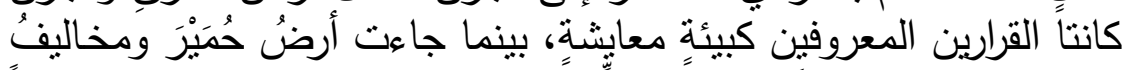

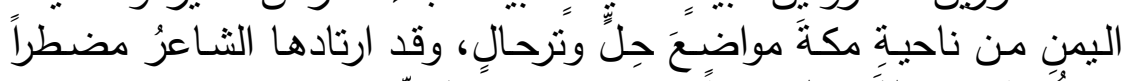

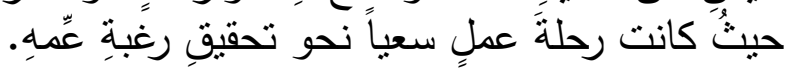

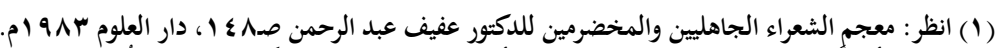

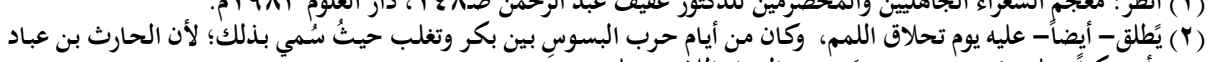

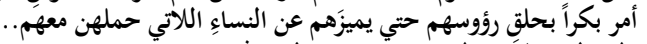

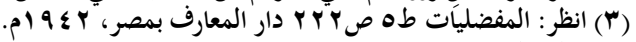

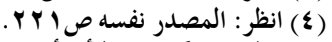

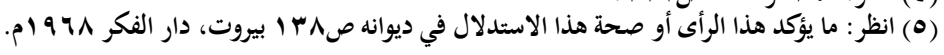




\section{شخصيته وصفاتها:}

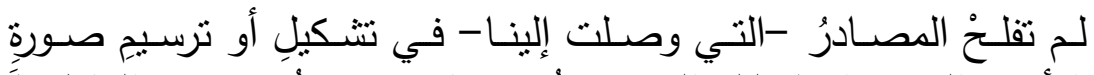

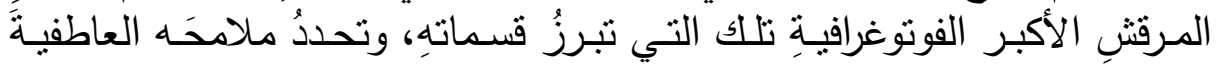

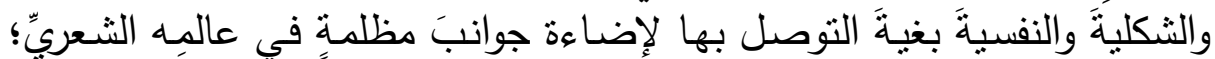

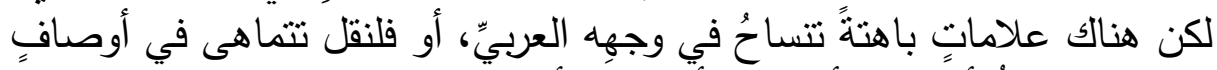

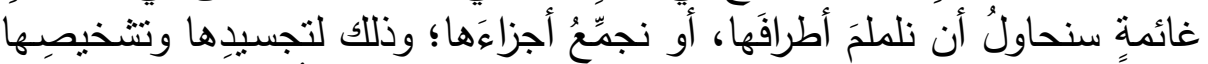

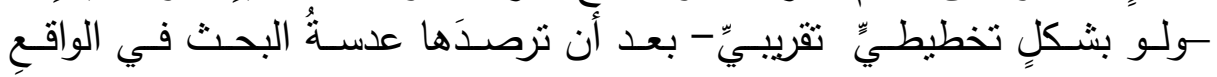
الانقرائيِّ.

مهما يكنْ من أمرِ فإن الناظر المتأملَ في شعرِ المرقشِِ الأكبرِ وأخباره

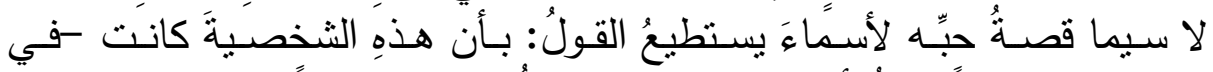

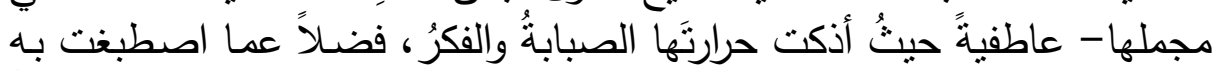

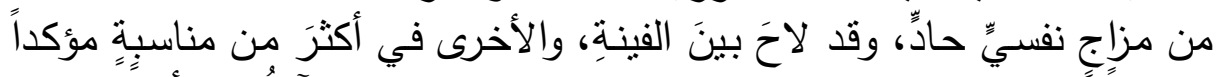

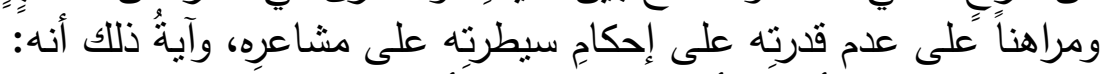

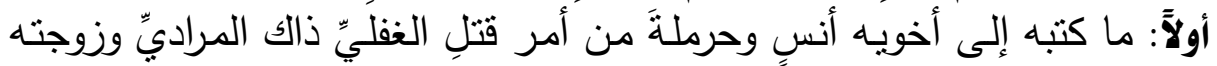

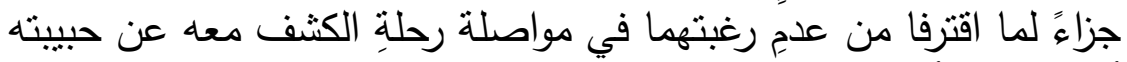

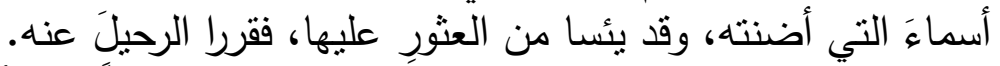

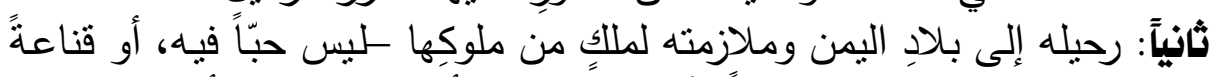

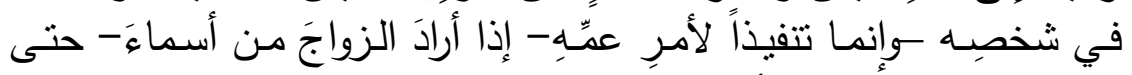

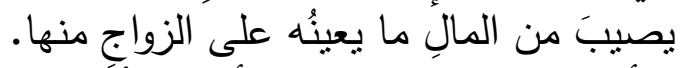

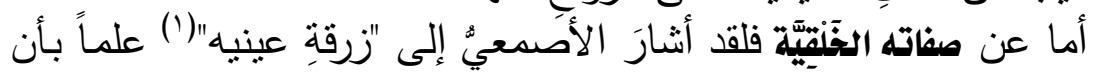

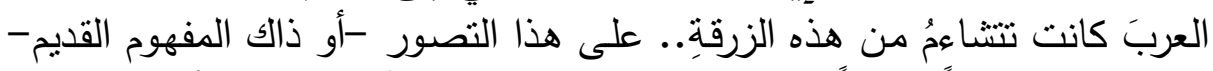

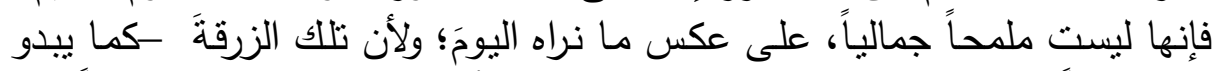

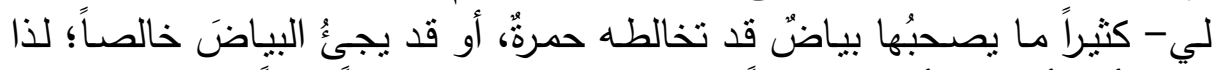

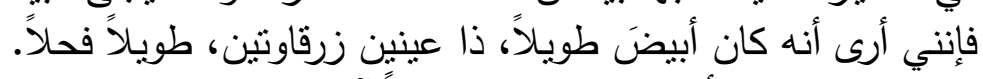

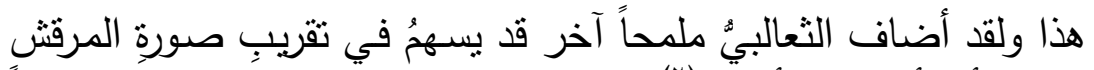

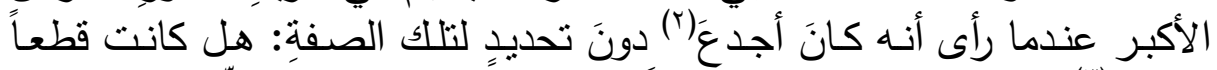

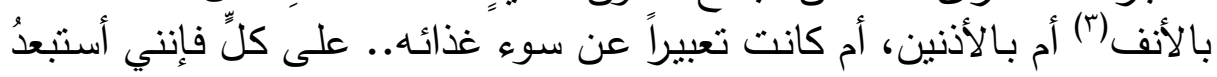




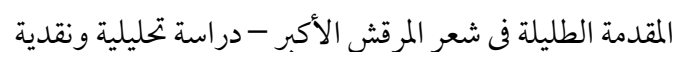

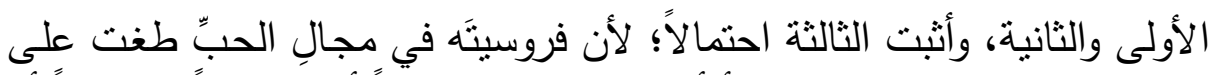

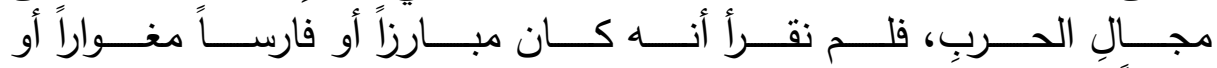
مغامراً وقد جُرِحَ....!

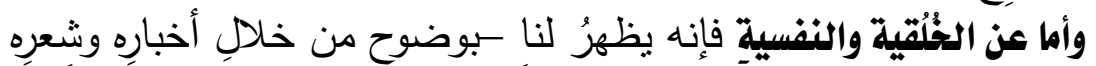

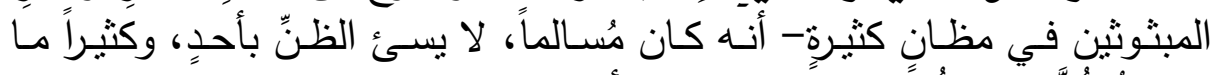

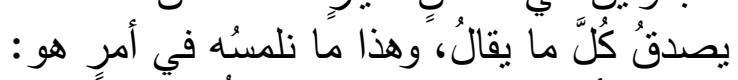

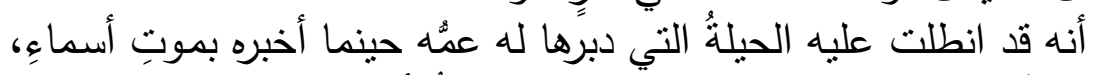

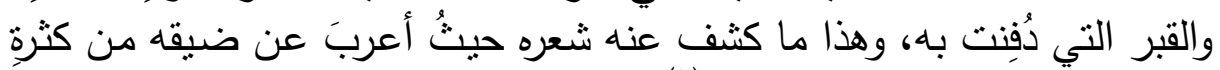

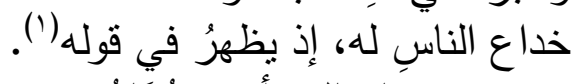

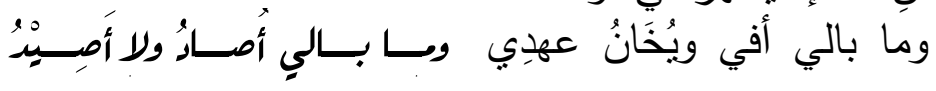

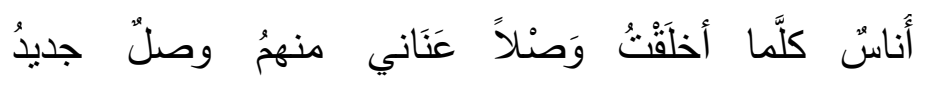
وقوله:

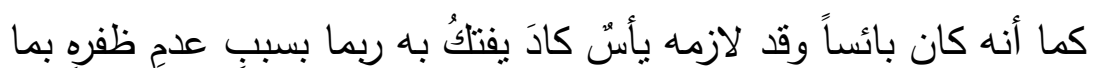

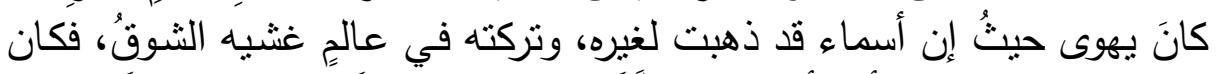

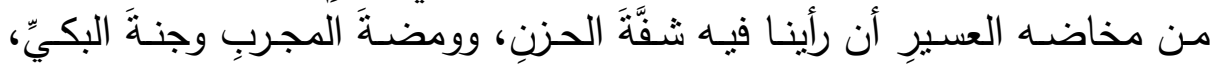

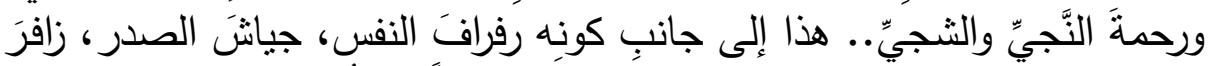

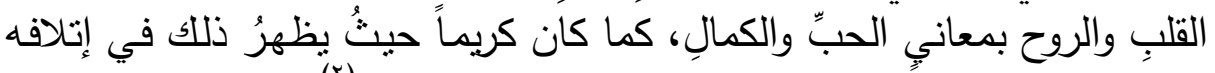

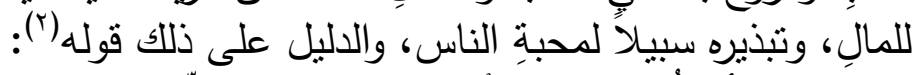

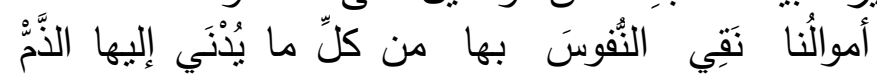

\section{حياته:}

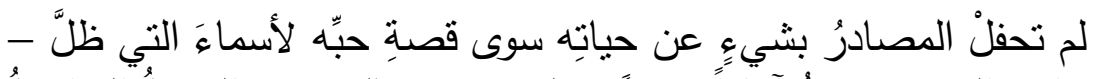

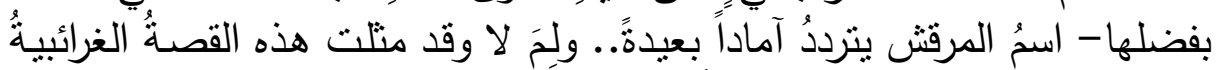

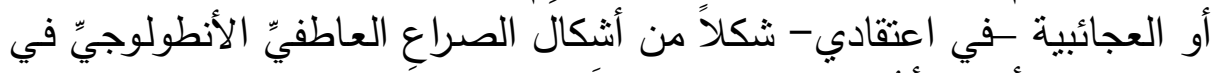

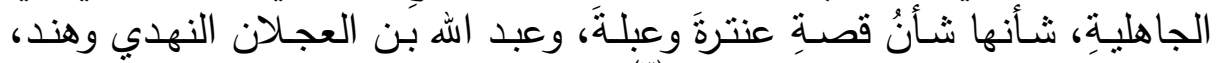

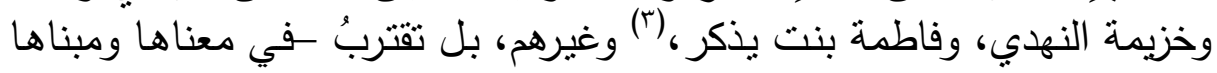

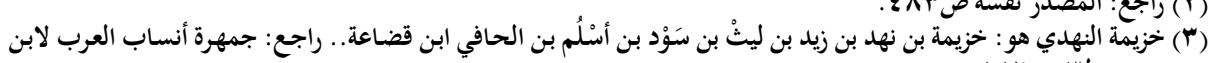




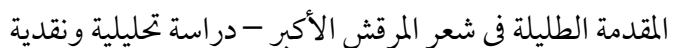

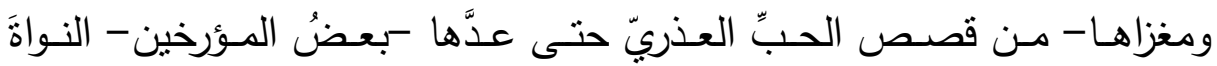

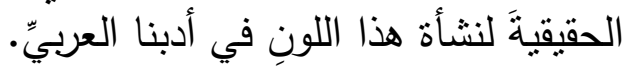

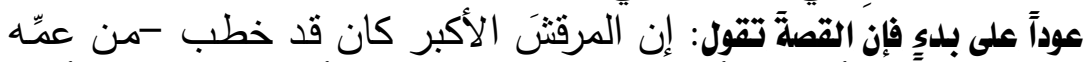

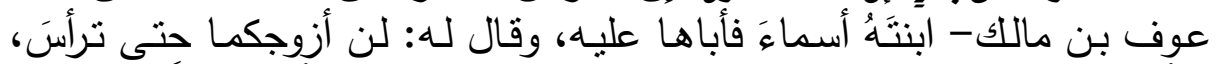

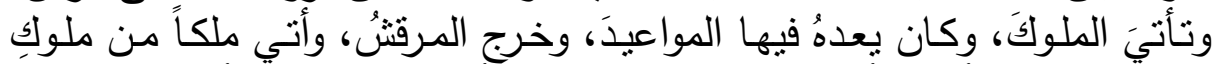

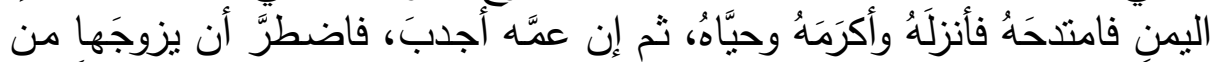

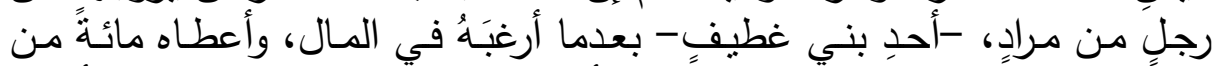

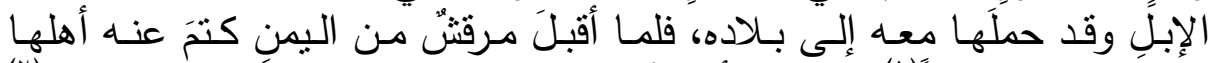

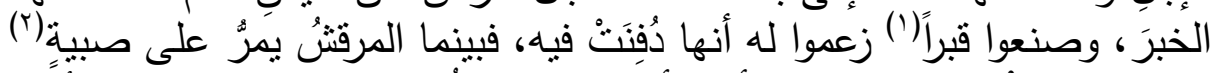

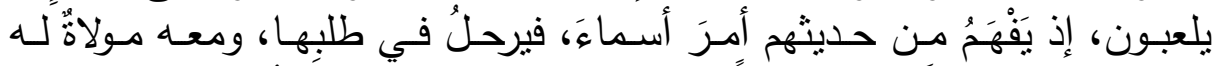

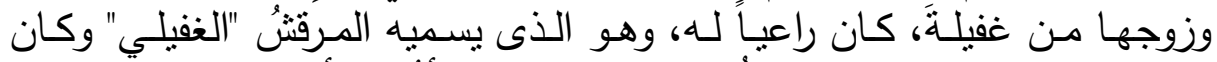

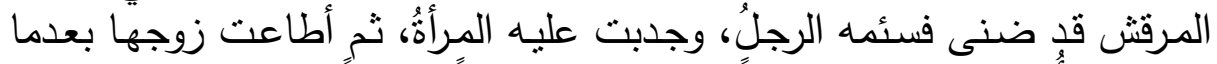

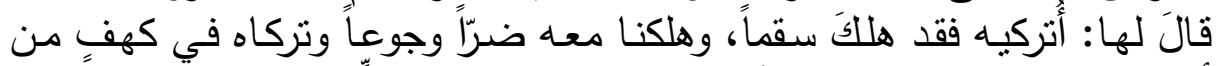

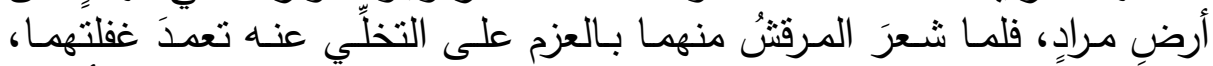

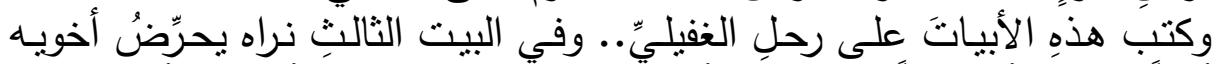

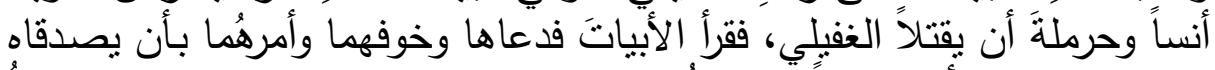

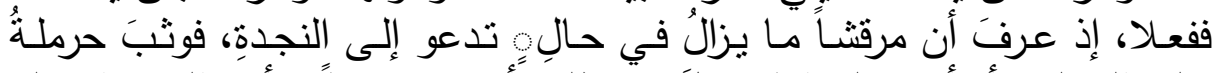

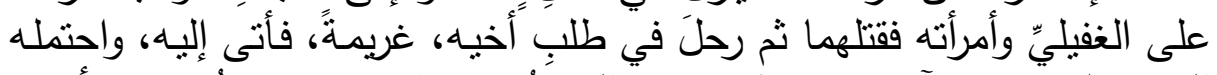

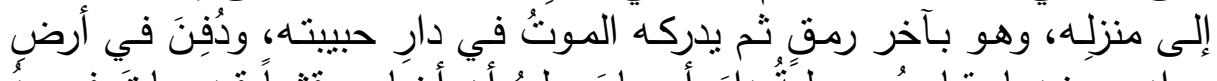

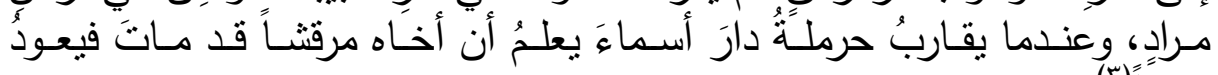

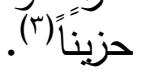

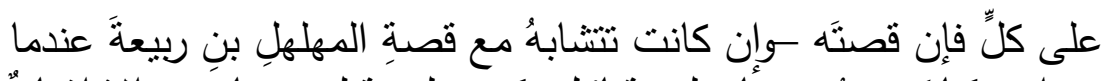

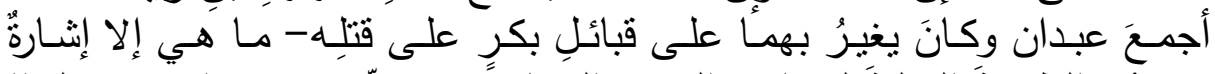

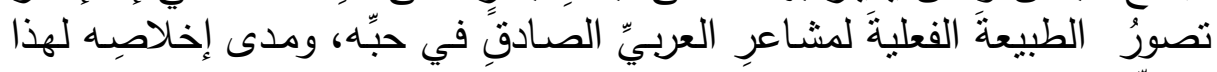

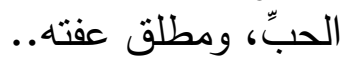

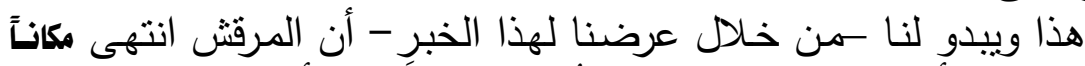

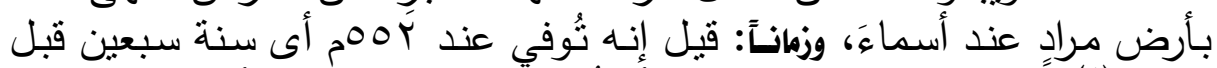

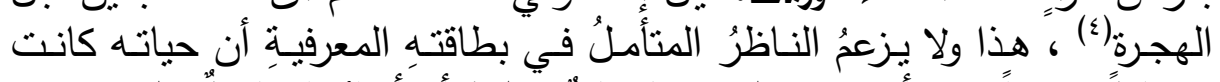

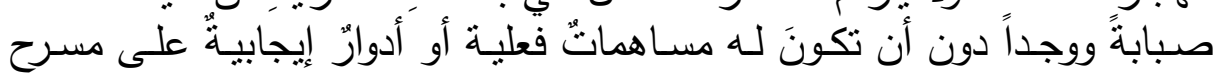




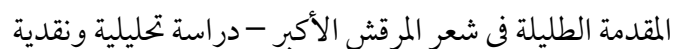

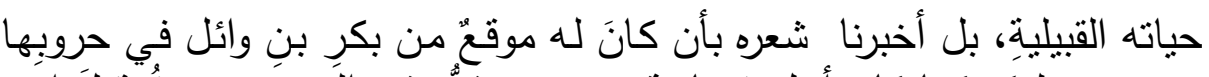

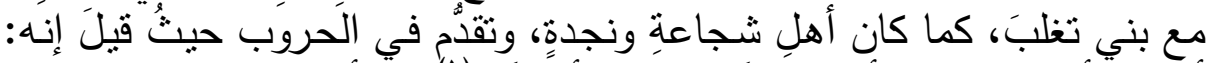

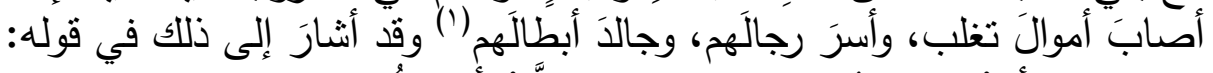

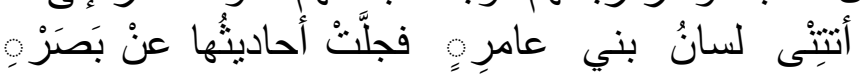

\section{طبقته وشاعريته:}

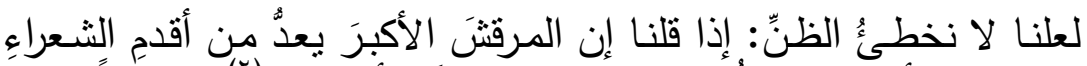

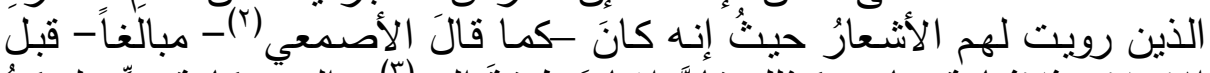

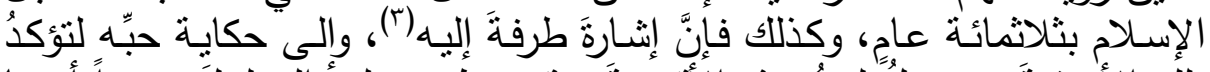

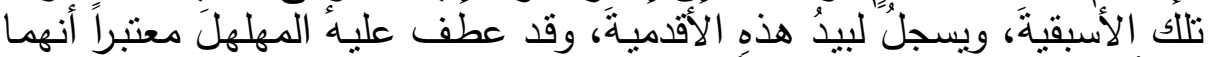

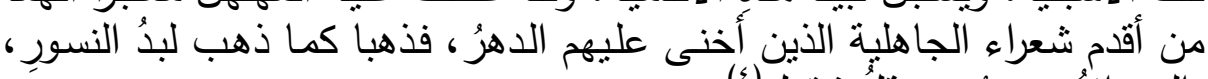

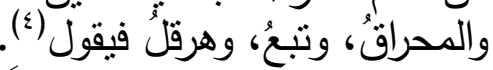

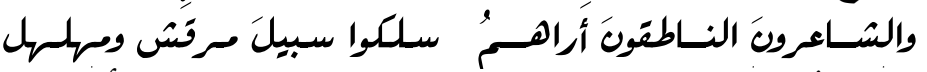

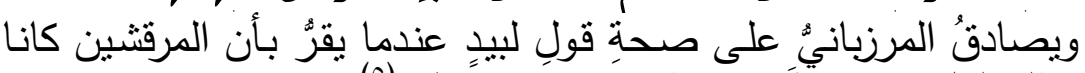

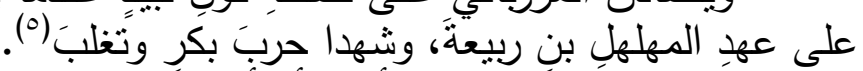

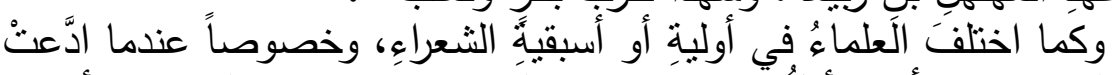

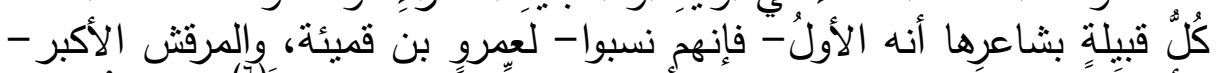

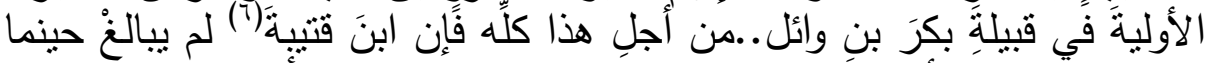

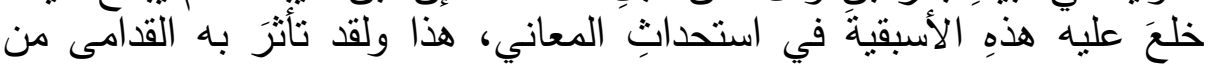

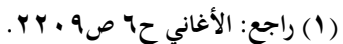

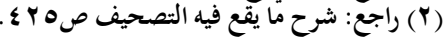

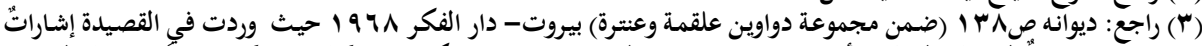

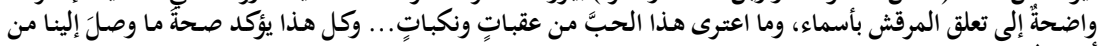
أخبار له.

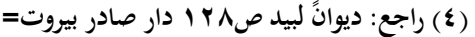

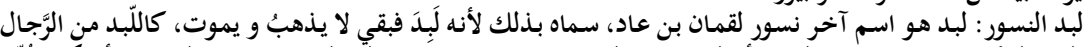

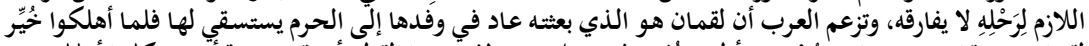

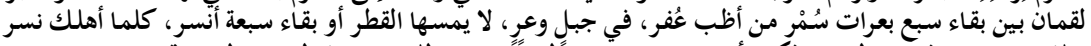

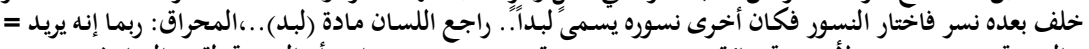

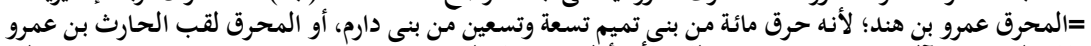

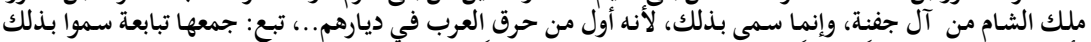

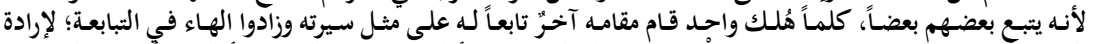

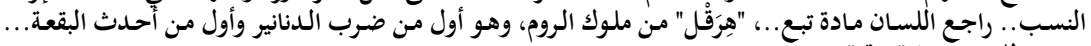
راجع: اللسان مادة "هرق".

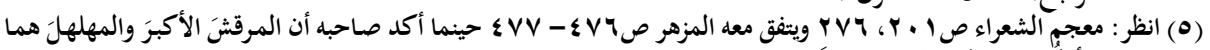

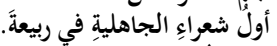




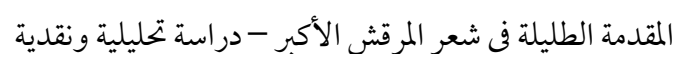

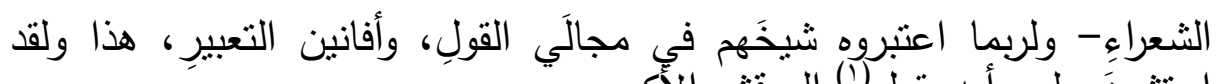

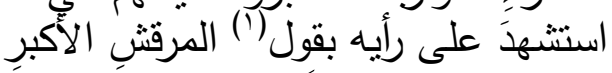

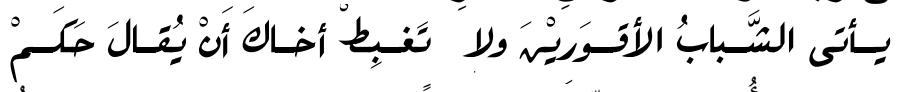

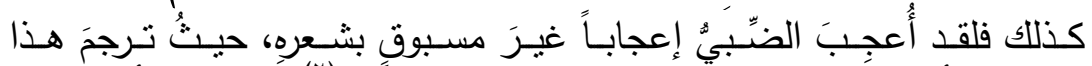

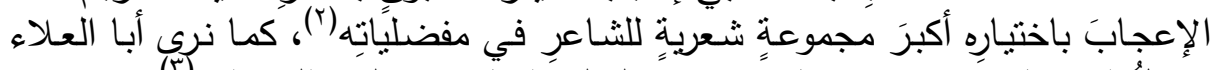

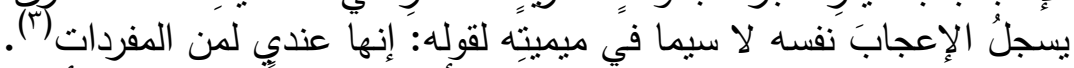

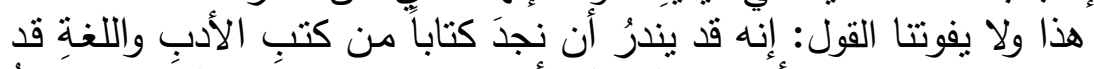

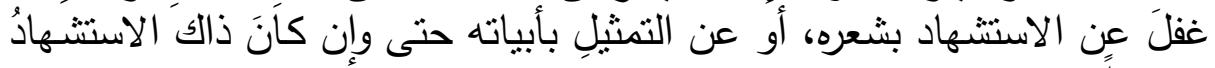

ولَمَّا نتساءلُ عن سرِّ هذا التفوقِ فإننا يمكننا ردّه إلي عاملين: محدوداً.

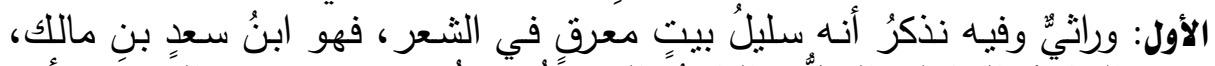

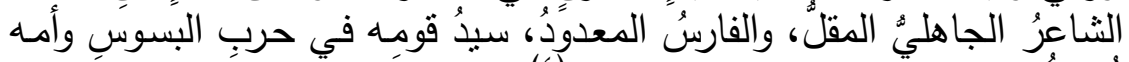

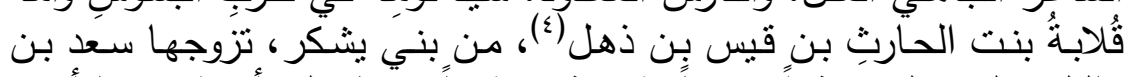

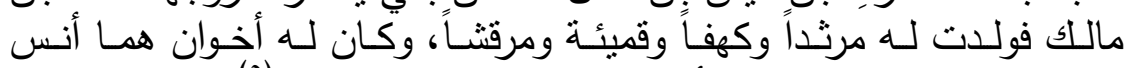

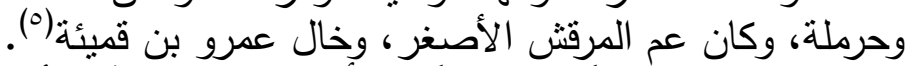

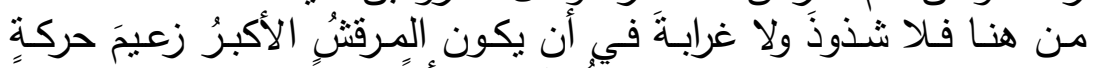

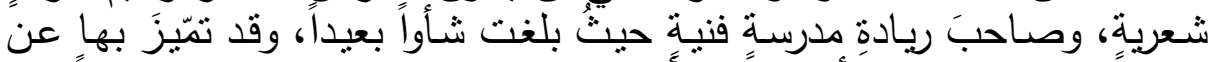

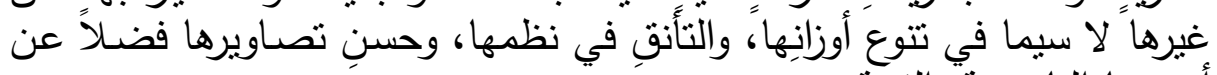

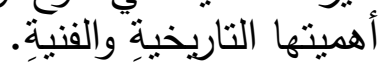

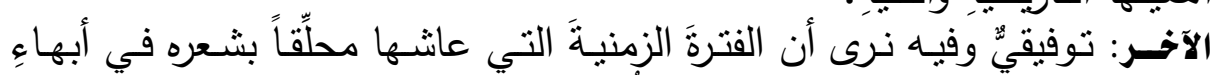

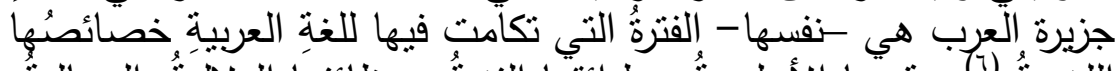

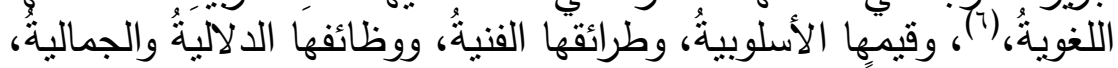

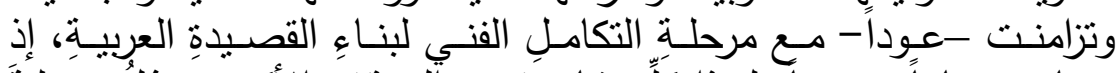

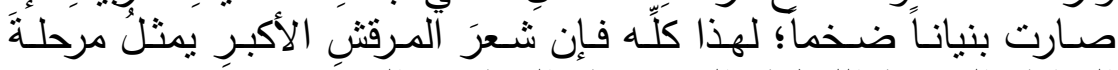

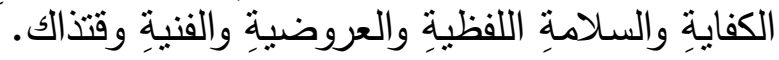

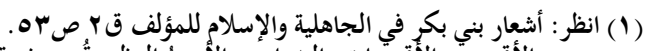

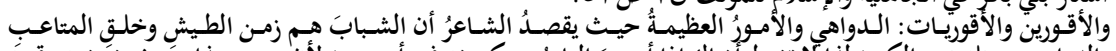

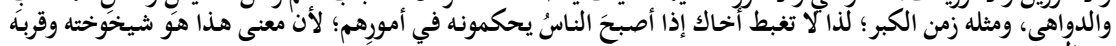

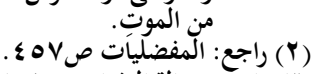
(צ)

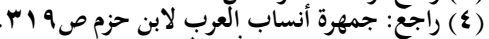

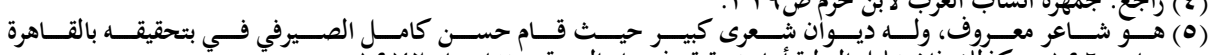

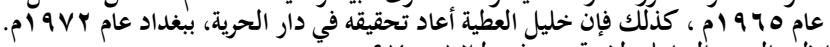

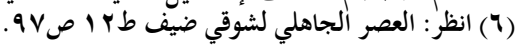




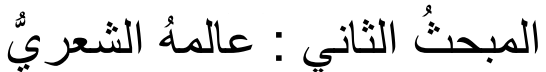

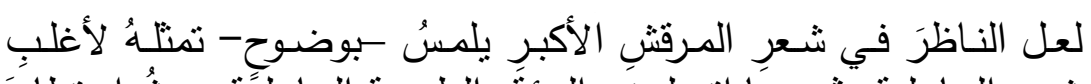

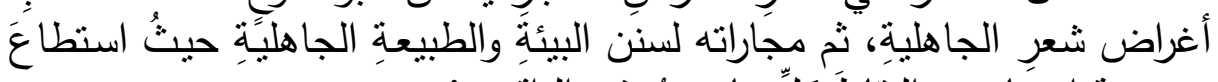

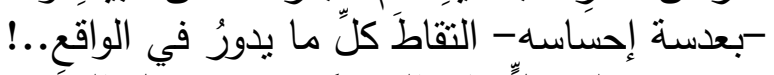

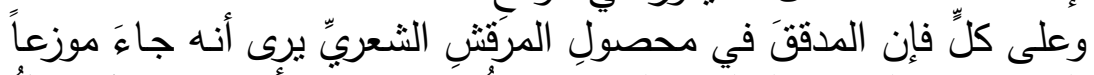

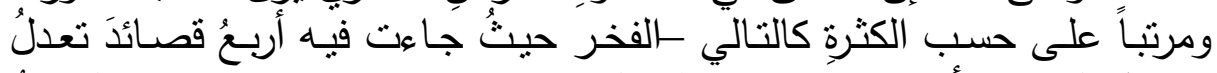

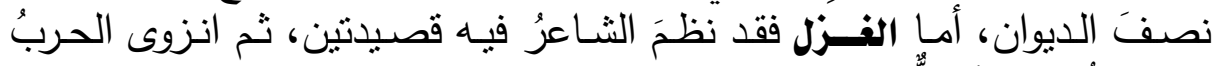

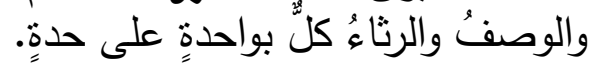

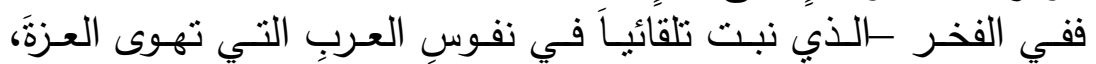

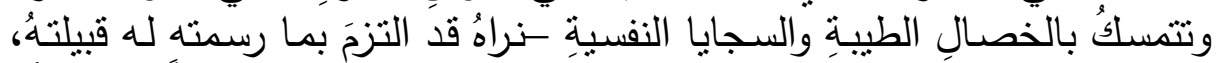

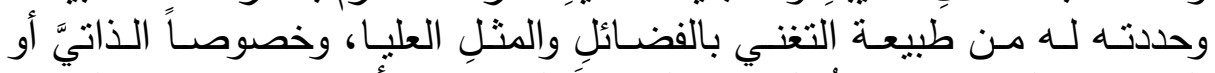

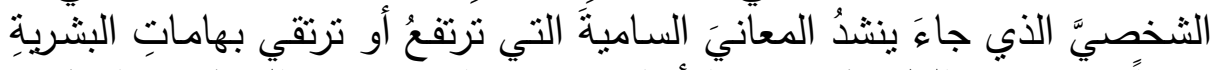

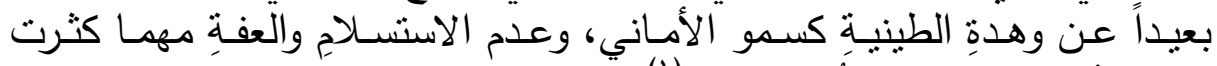

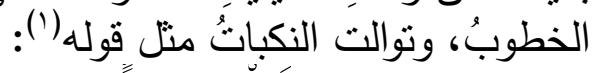

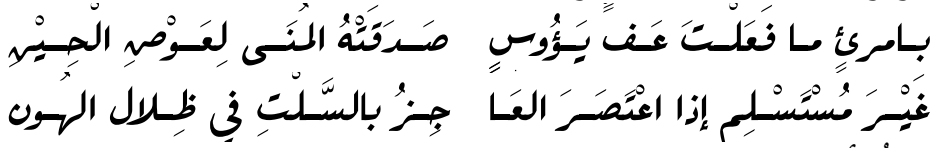

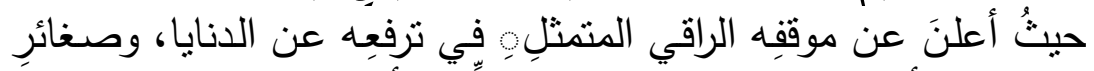

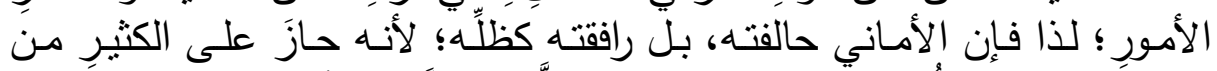

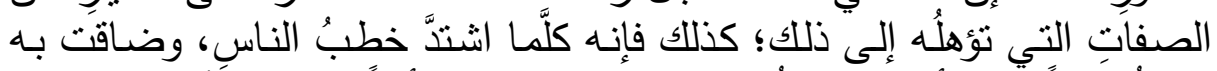

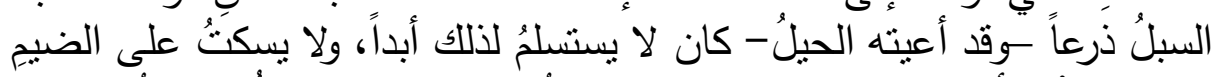

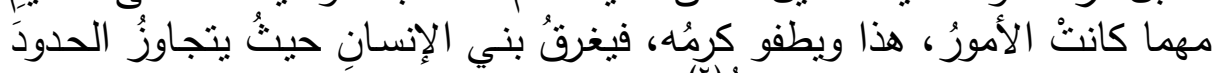

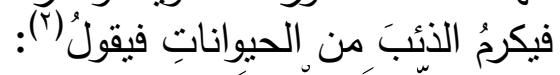

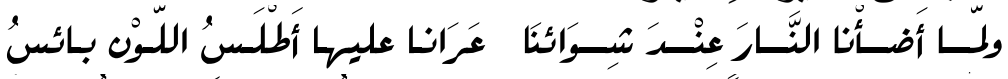

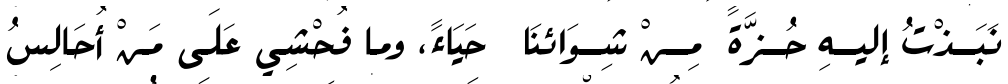

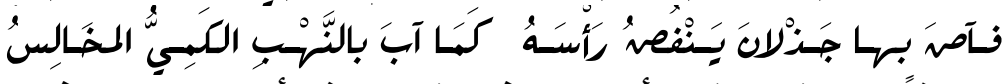

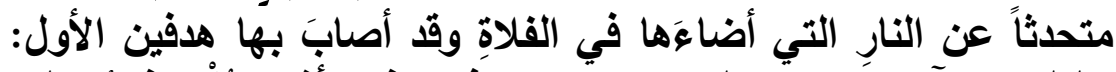

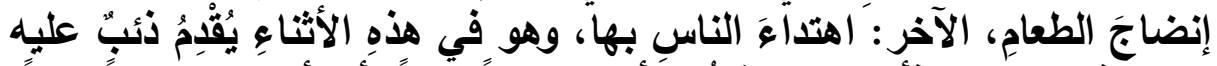

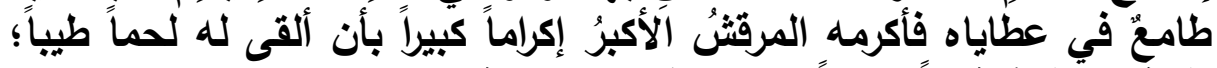

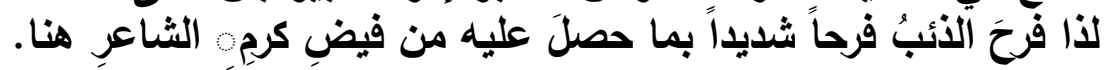




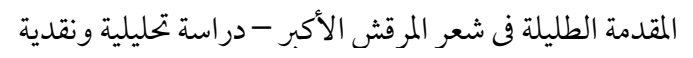

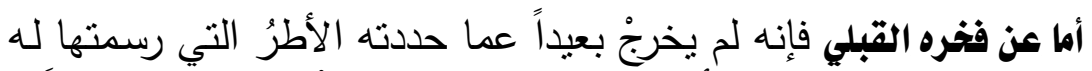

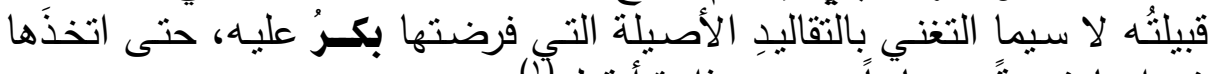

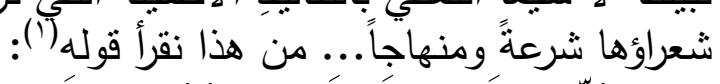

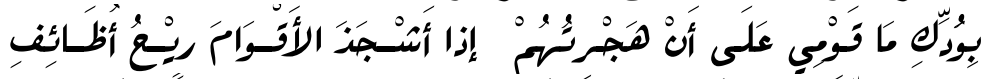

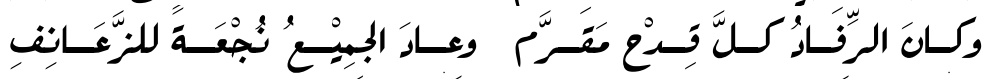

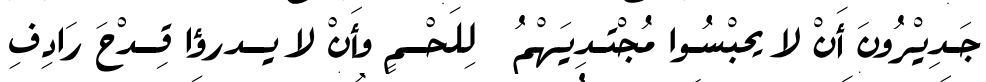

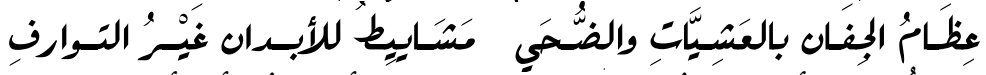

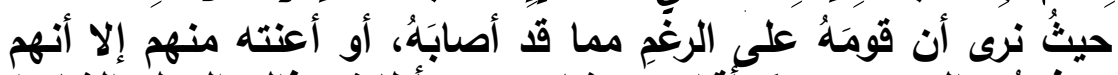

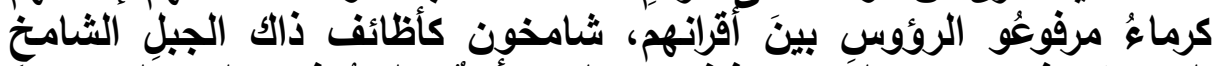

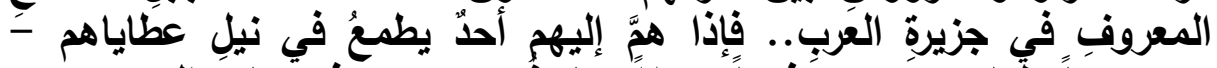

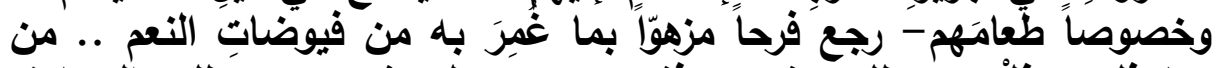

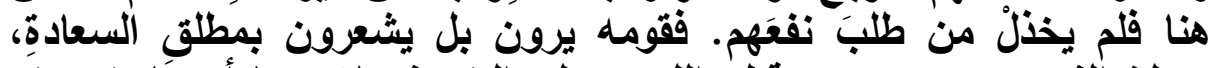

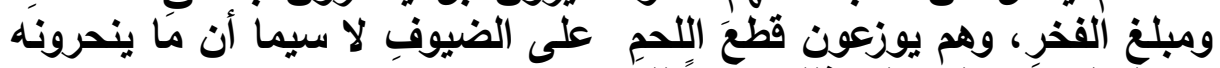

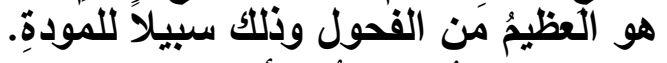

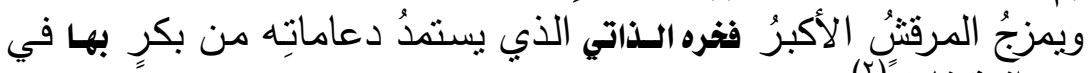

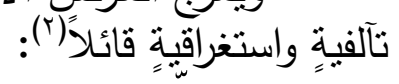

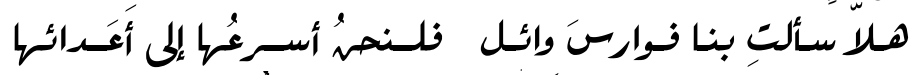

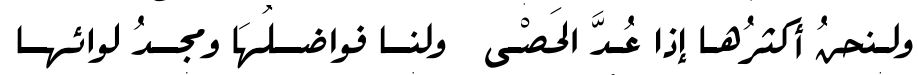

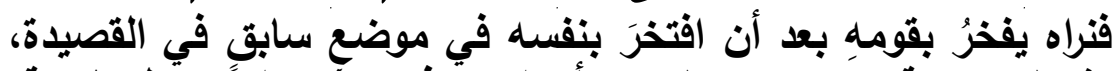

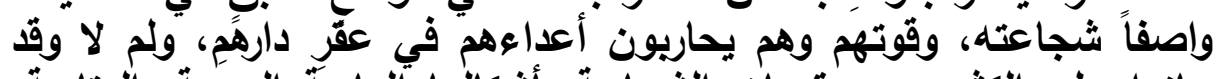

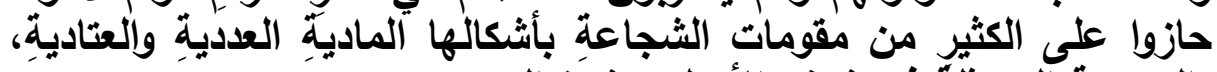

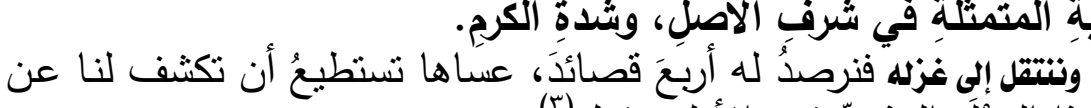

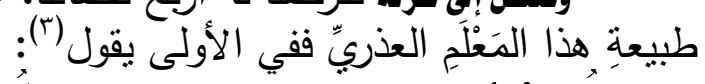

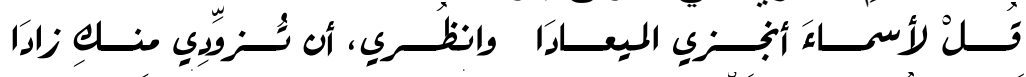

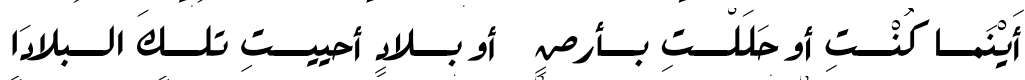

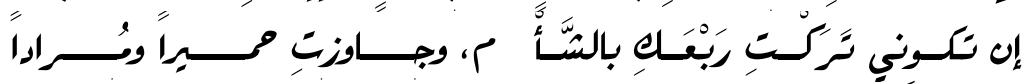

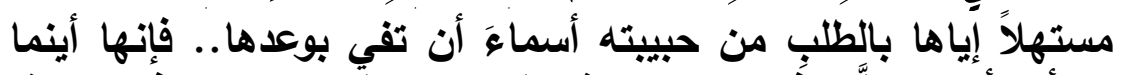

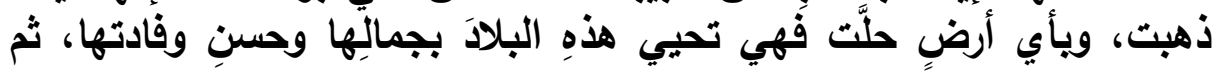




\section{المقدمة الطليلة في شعر المرقش الأكبر - دراسة تحليلية ونقدية}

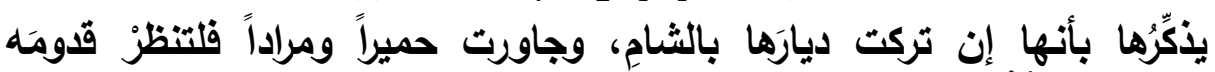

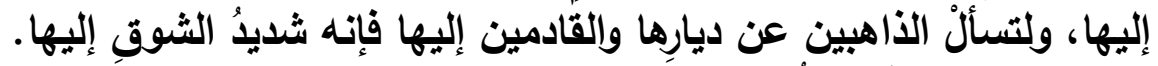

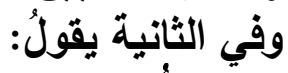

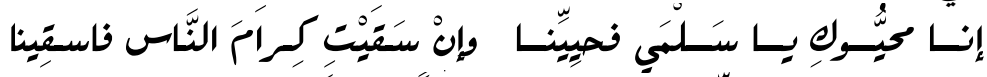

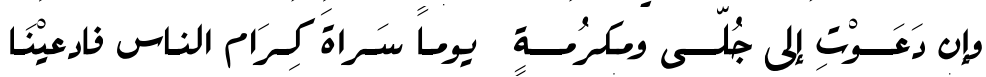

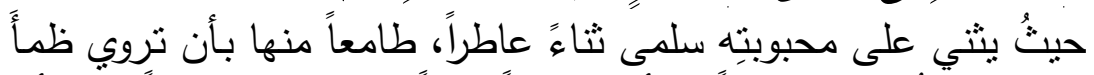

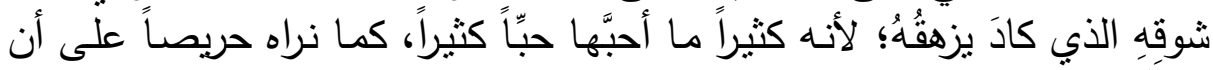

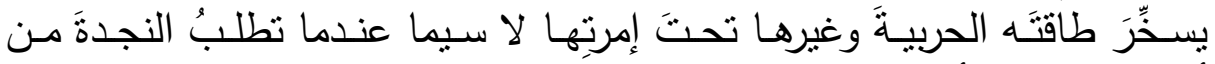

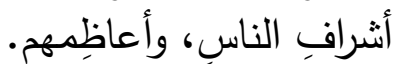

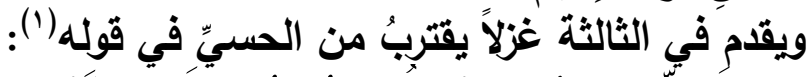

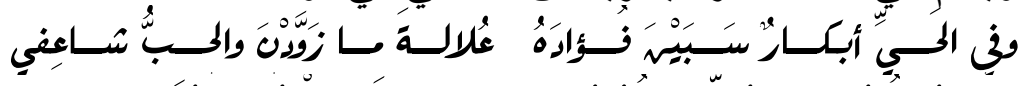

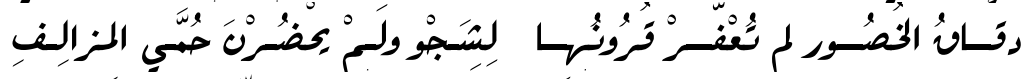

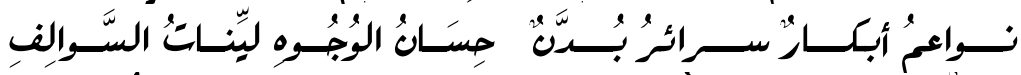

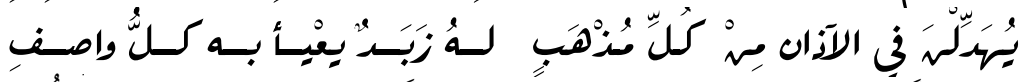

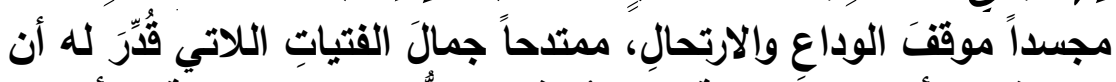

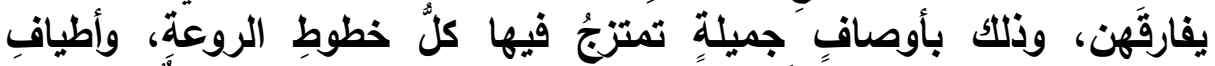

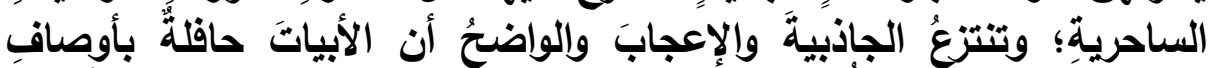

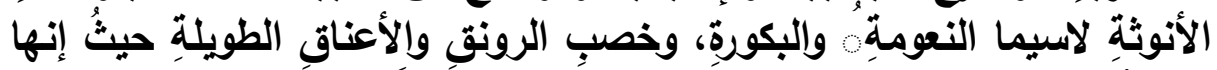

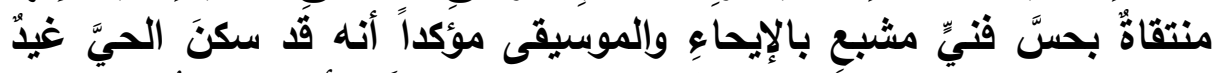

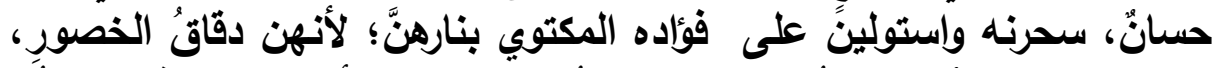

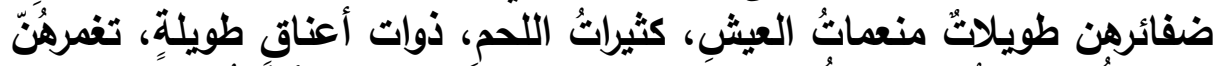

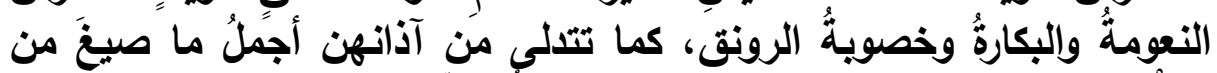

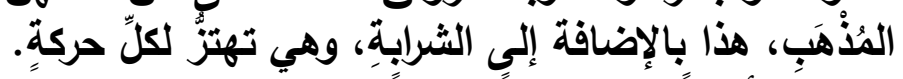

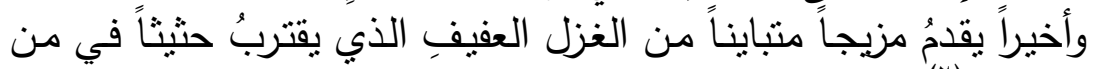

$$
\text { الصريح في قوله (r): }
$$




\section{المقدمة الطليلة في شعر المرقش الأكبر - دراسة تحليلية ونقدية}

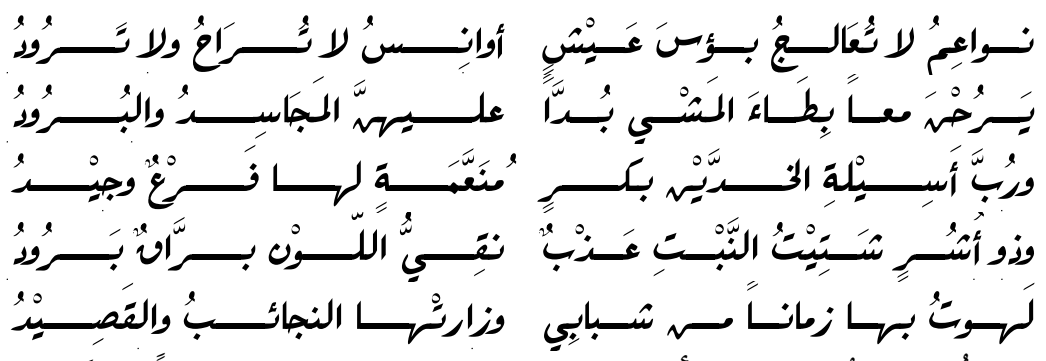

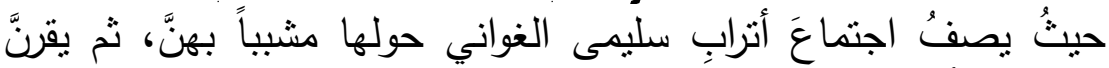

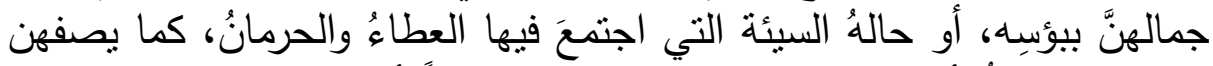

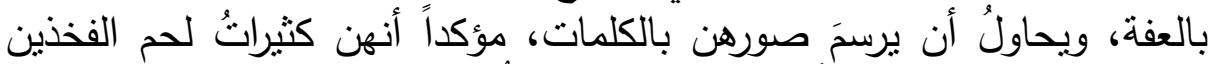

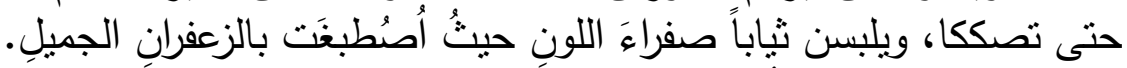

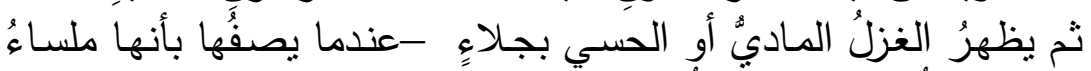

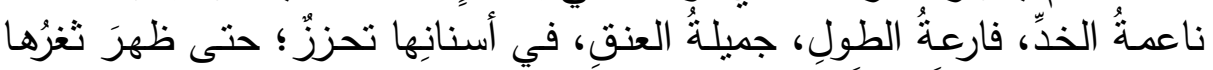

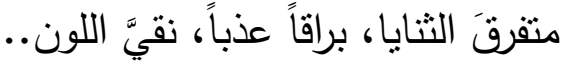

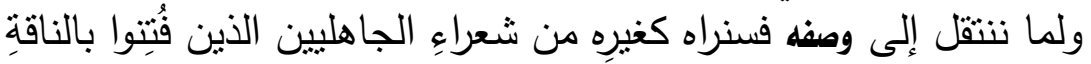
والفرسِ.. فقي الناقِة نقرأ قوله:

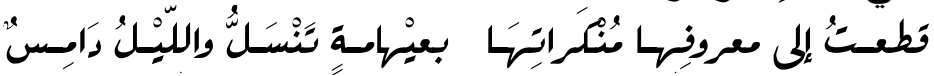

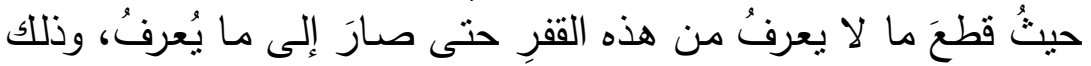

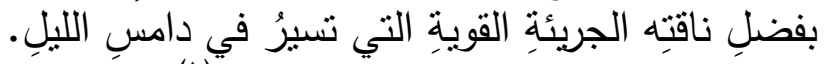

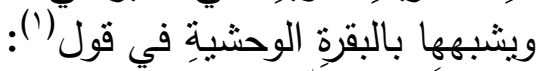

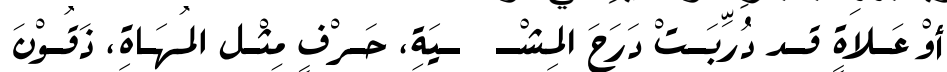

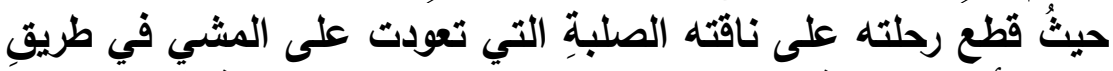

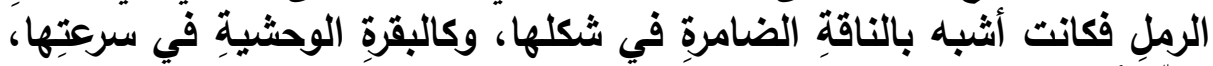

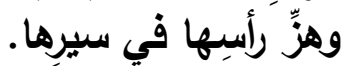

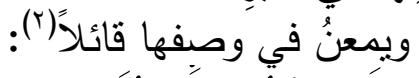

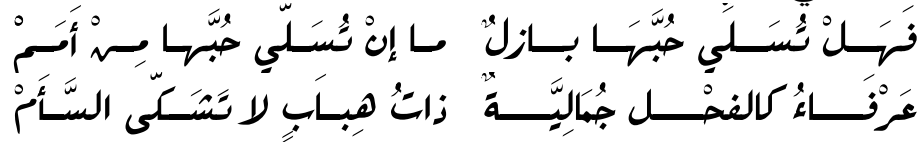

$$
\begin{aligned}
& \text { العلاة: سندان الحدد، الحرف: الناقة الضامر، والمهاة: بقرة الوحش. }
\end{aligned}
$$

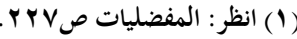

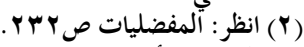

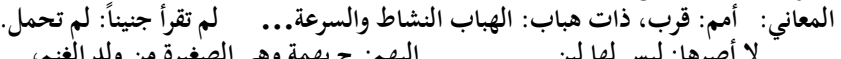

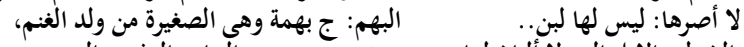

$$
\begin{aligned}
& \text { الشول: الإبل التى لا ألبان لها..... نوت: سمنت، الرباع: الفررد: الثور. }
\end{aligned}
$$




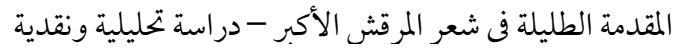

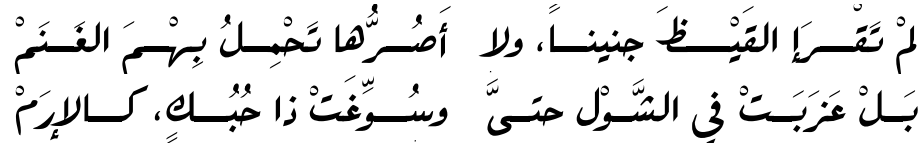

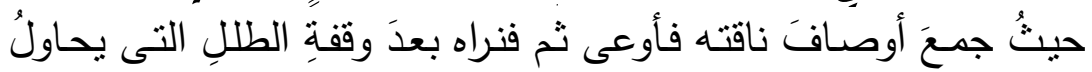

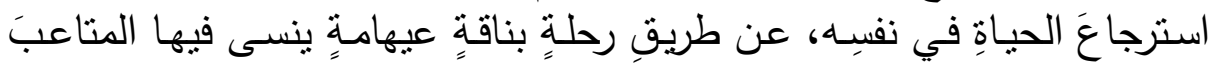

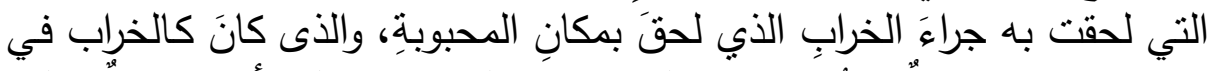

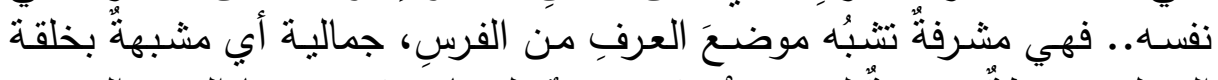

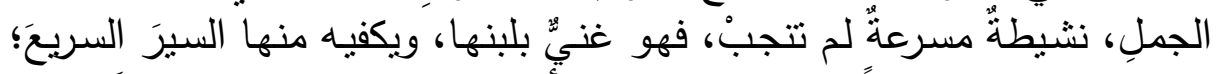

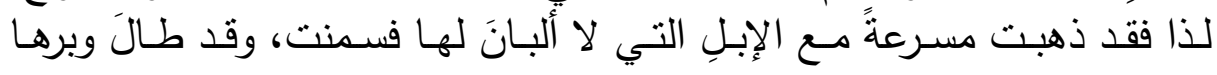
فصارت كالجملِ.

أما الفرسَ فإنها لم يحظَ في شعرةَ إلا بقوله (1):

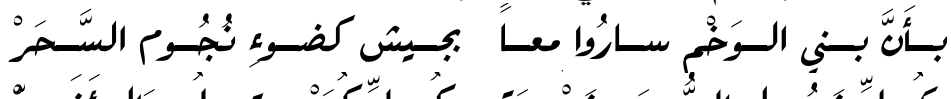

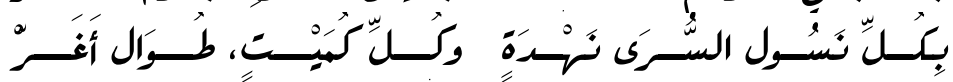

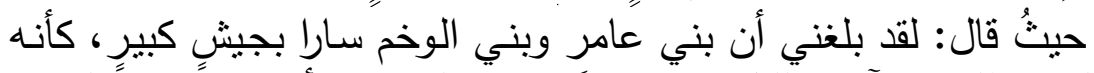

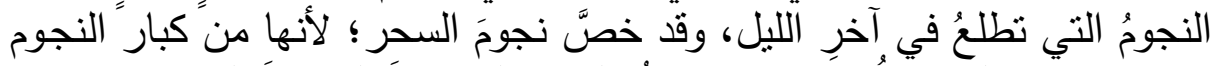

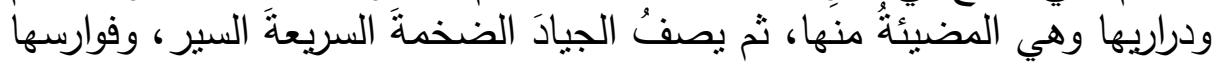

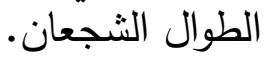

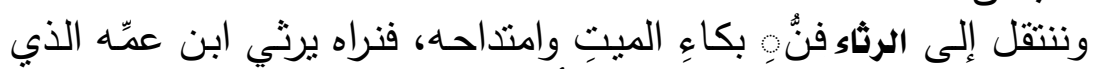

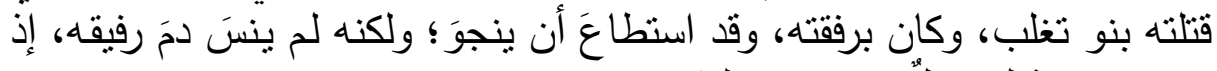

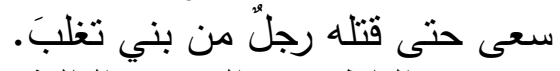

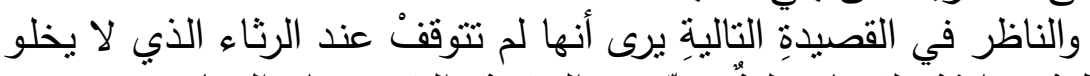

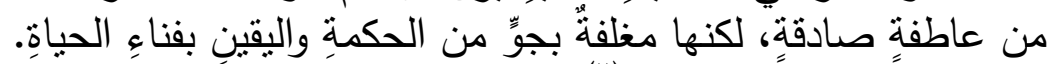

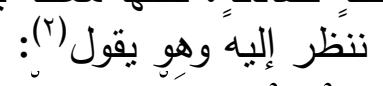

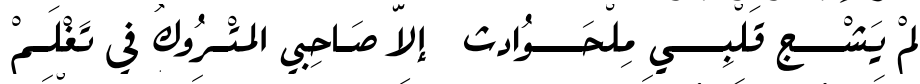

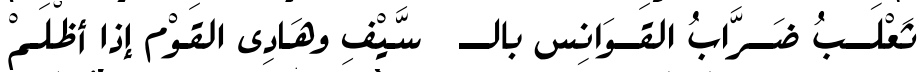

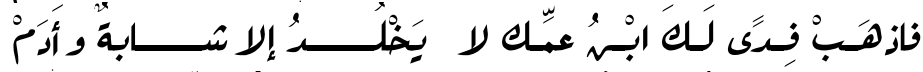

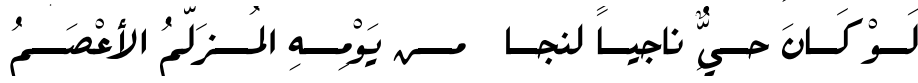

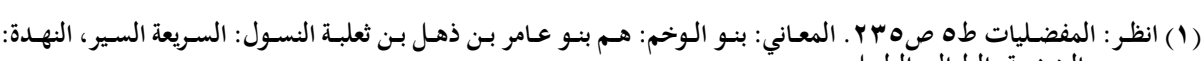

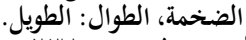

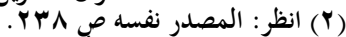

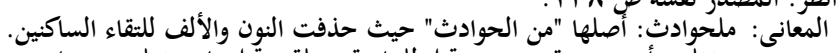

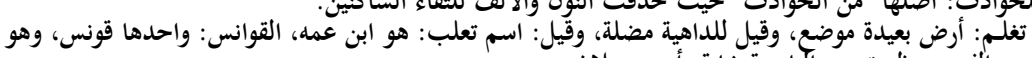
من الفرس عظم تحت الناصية شابة وأدم: جبلان. 


\section{المقدمة الطليلة فى شعر المرقش الأكبر - دراسة تحليلية ونقدية}

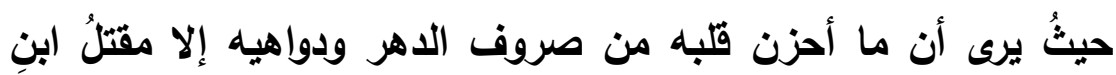

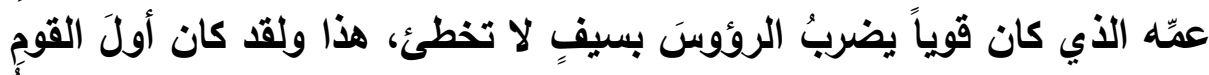

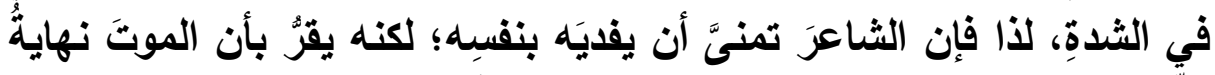

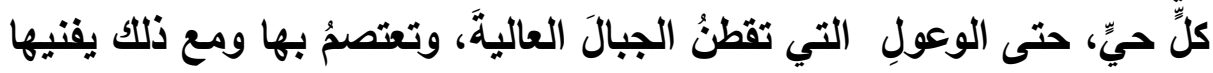

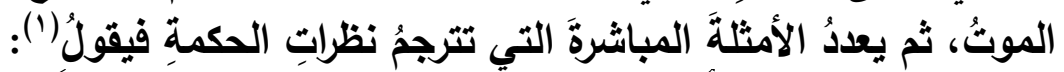

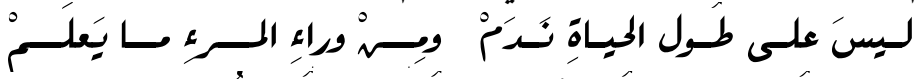

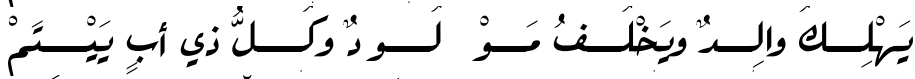

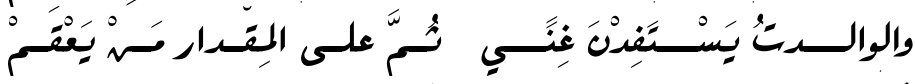

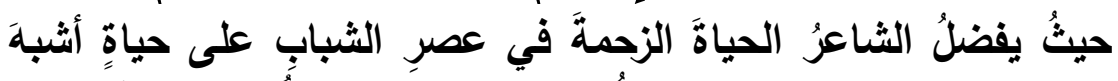

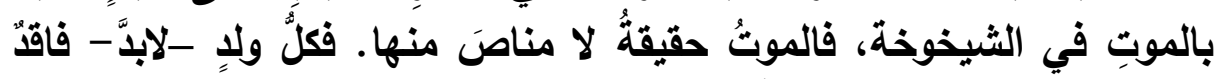

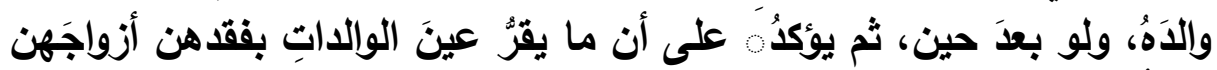

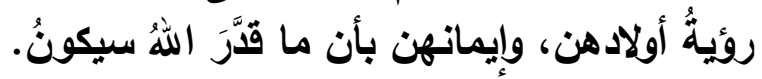

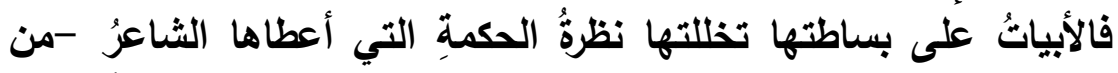

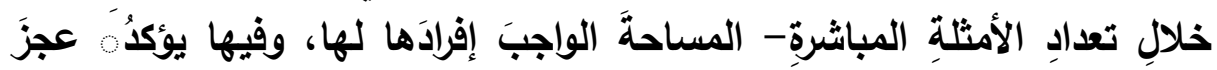

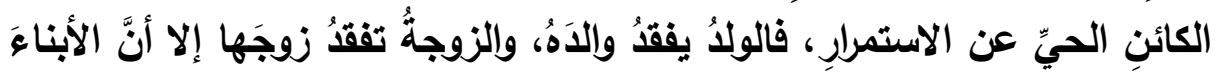

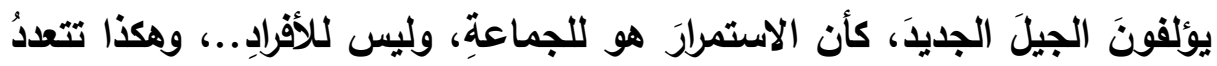

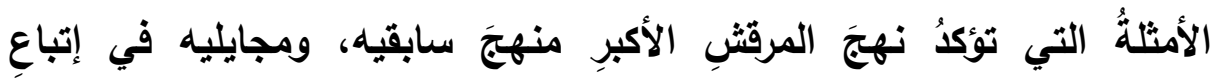

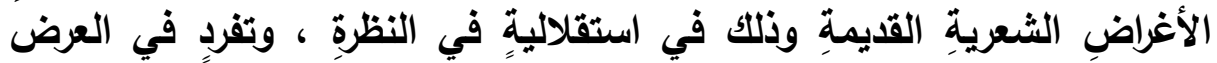

والتقديم .

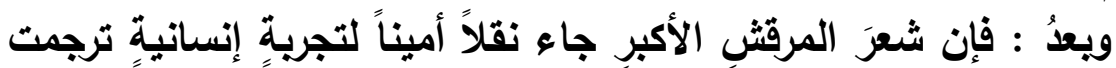

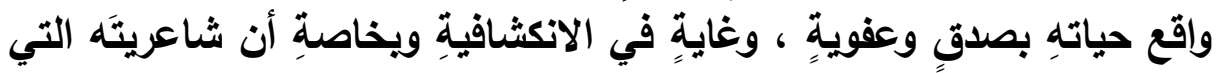

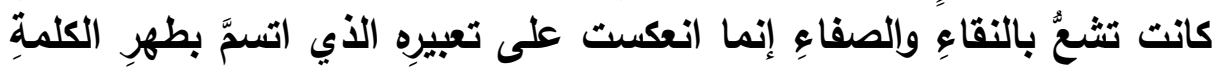

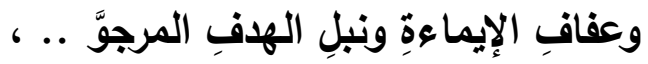




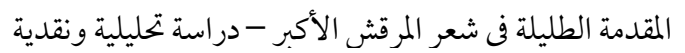

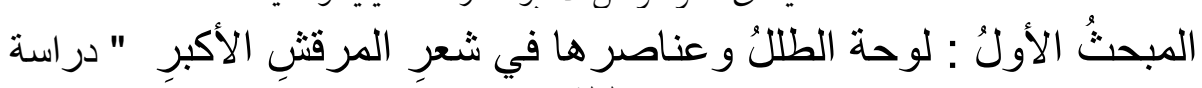
تحليلة"

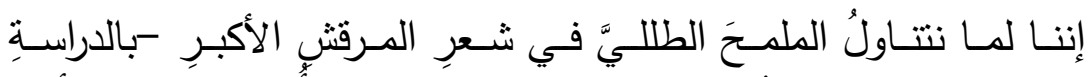

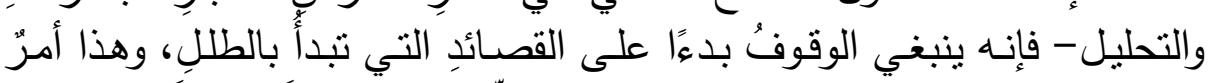

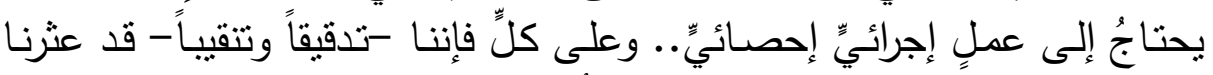

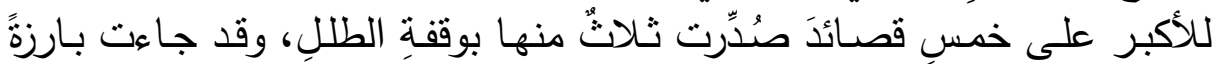

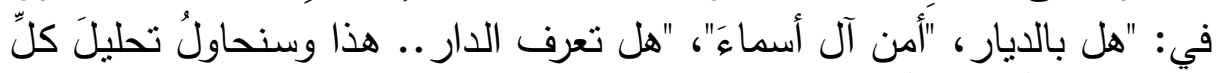
مقدمةٍ تحليلاً مفصَّلًا حتى نستطيحَ الوقوفَ على ملامحِ لوحةِ الطللِ وقسماتِها.

\section{وعلى كلّّ فلنبلدأ بقصيدة هل بالديار:}

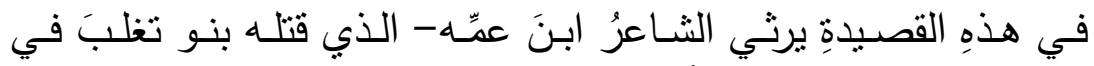

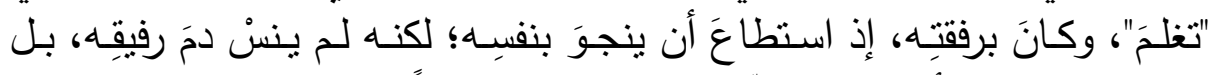

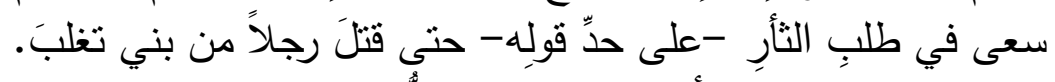

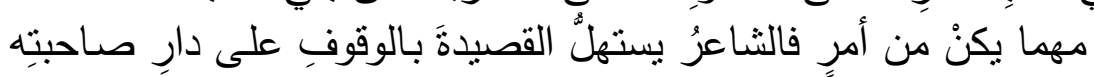

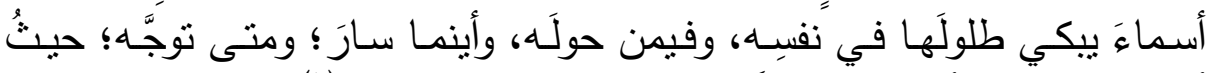

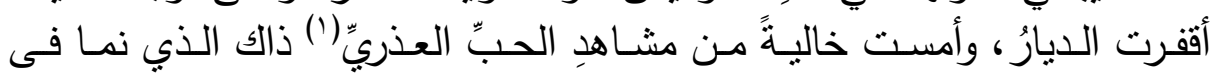

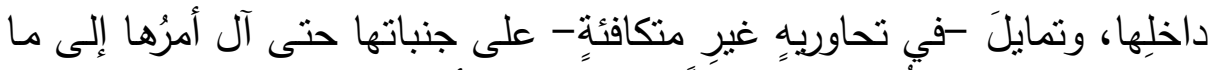

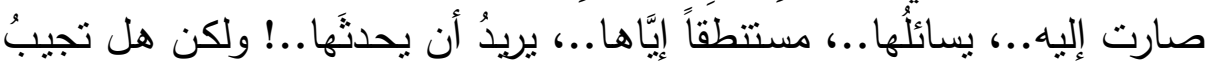

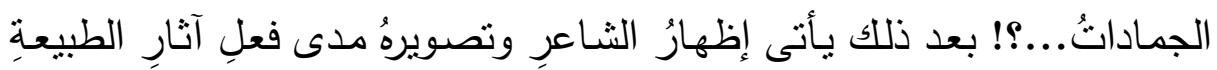

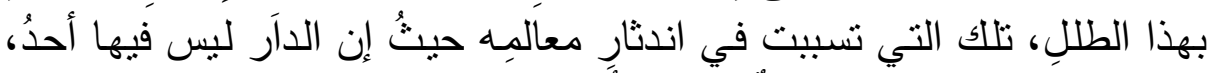

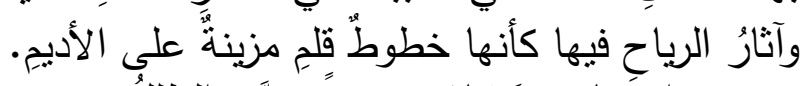

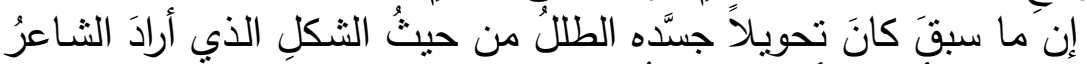

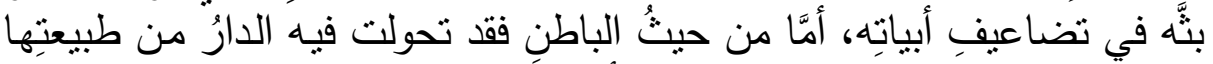

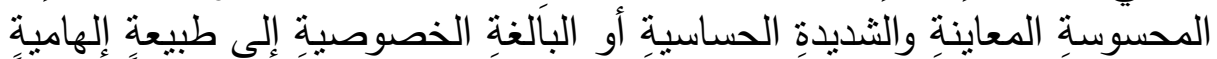

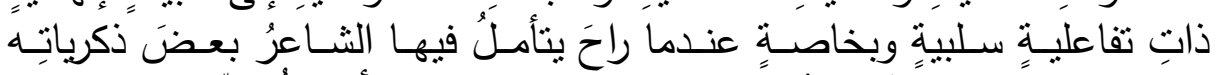

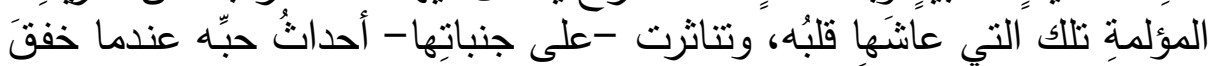

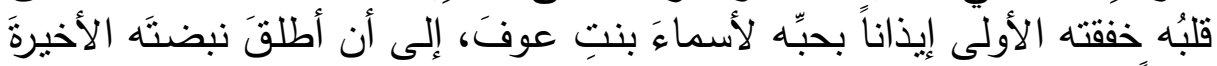

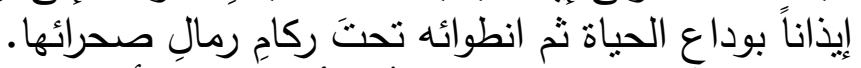

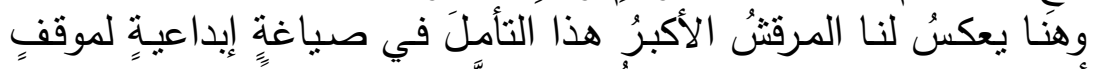

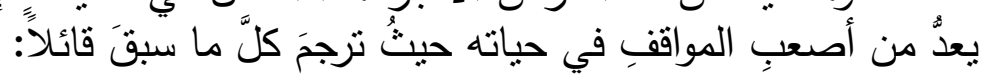




\section{المقدمة الطليلة في شعر المرقش الأكبر - دراسة تحليلية ونقدية}

11)。

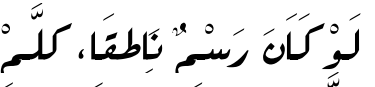

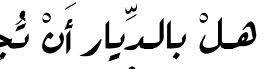

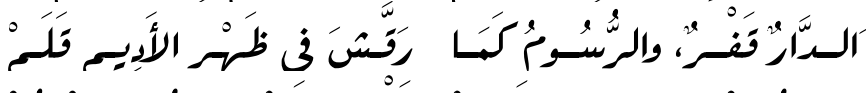

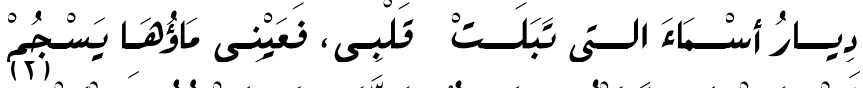

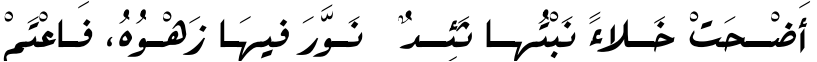

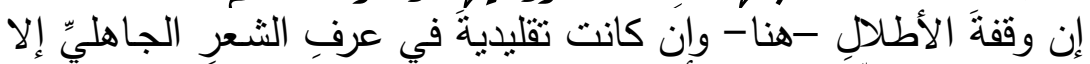

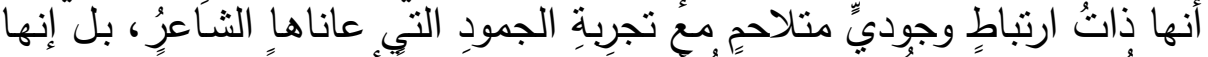

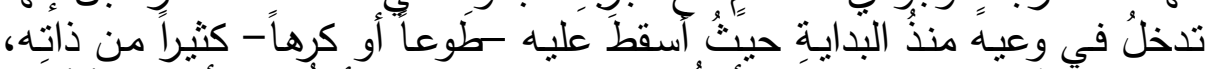

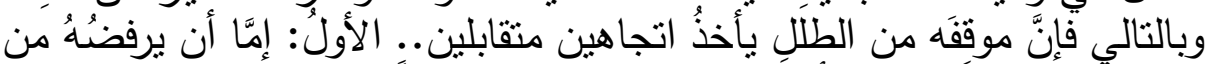

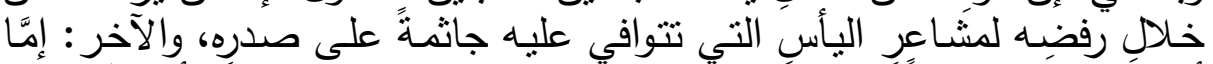

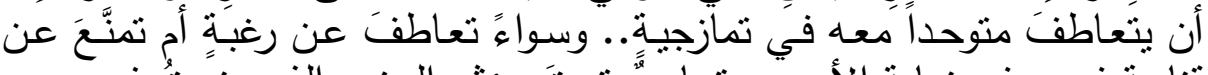

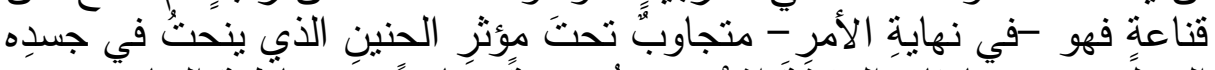

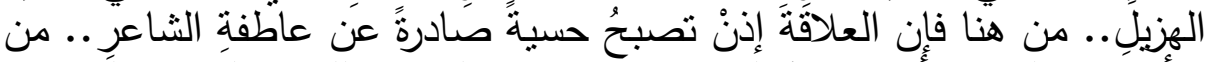

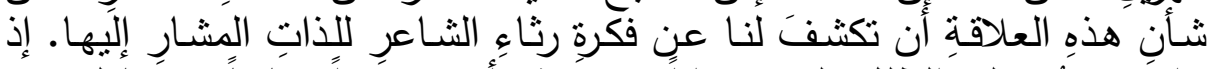

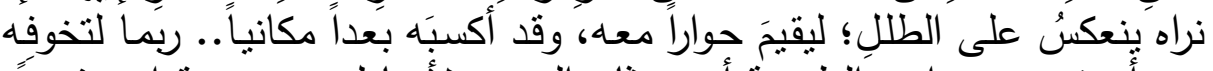

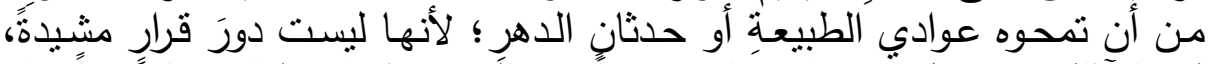

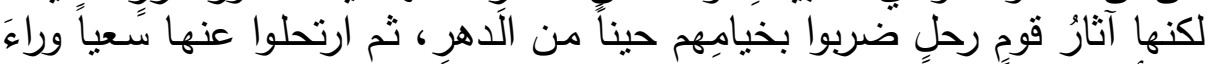

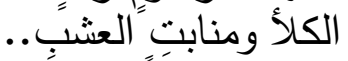

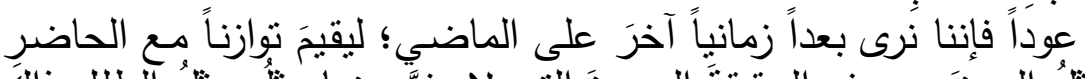

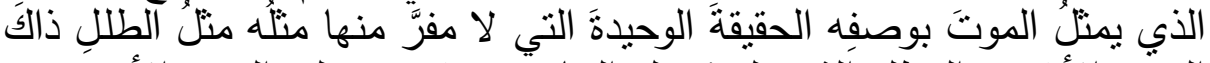

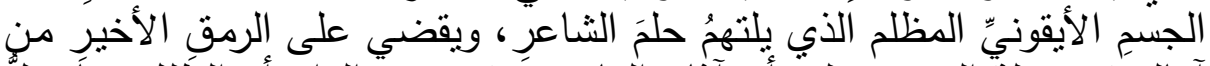

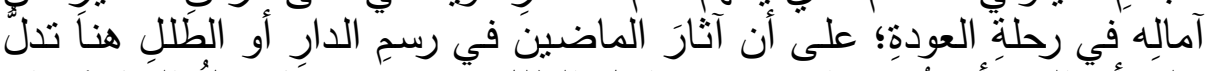

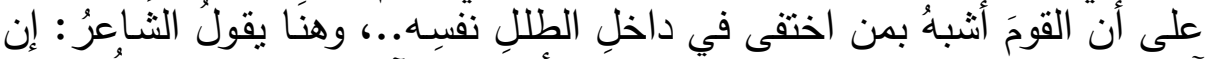

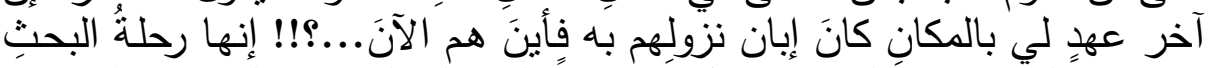

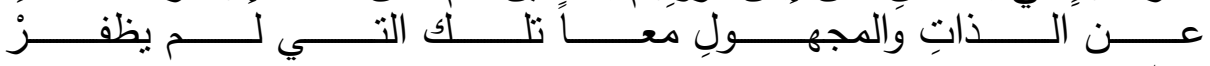

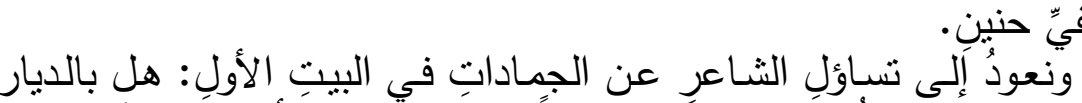

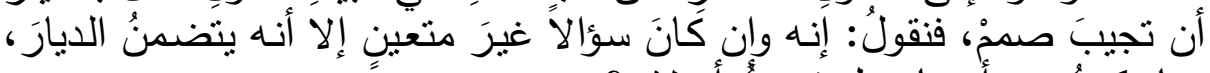

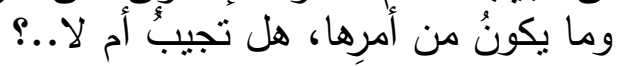

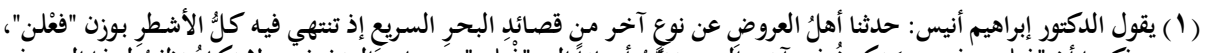

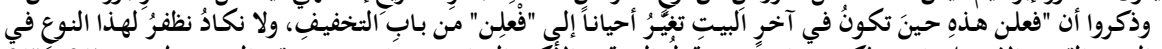

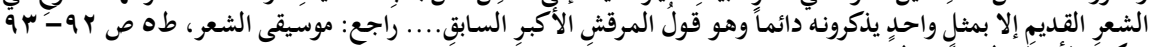




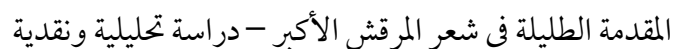

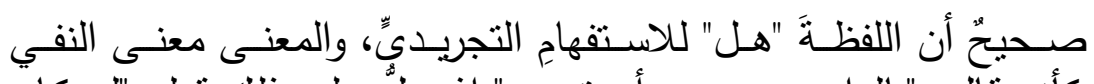

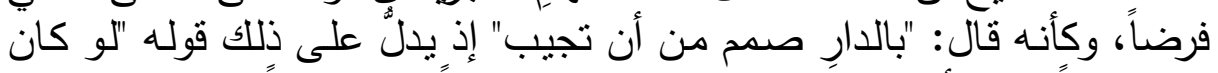

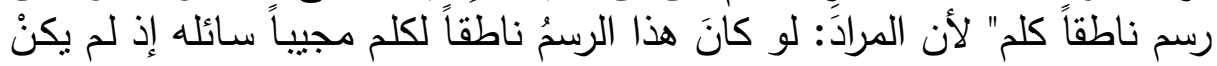

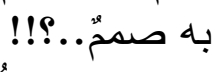

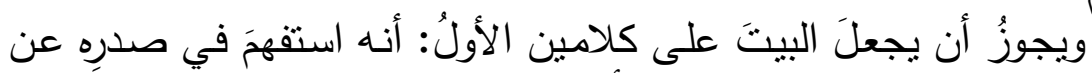

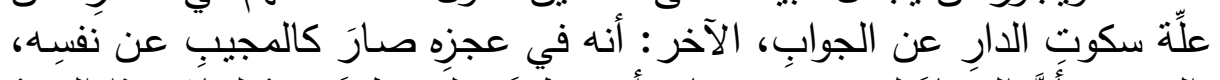

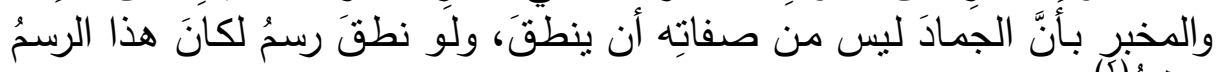

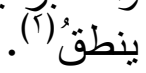

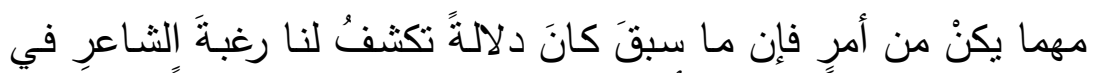

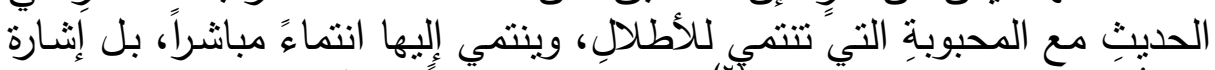

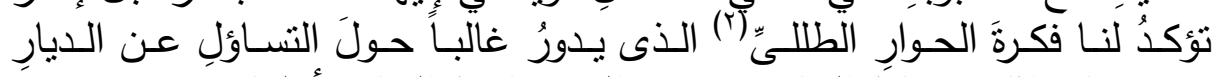

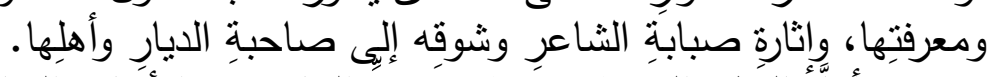

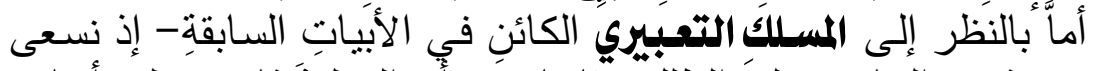

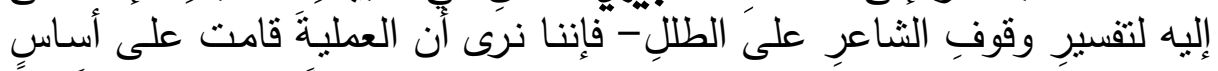

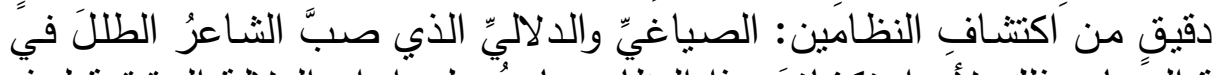

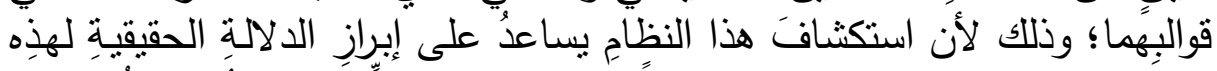

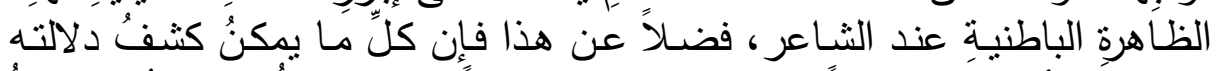

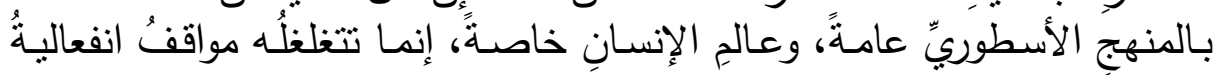

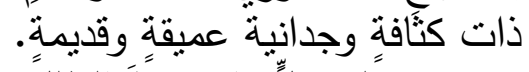

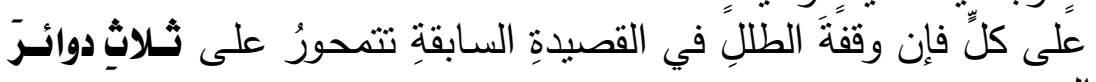

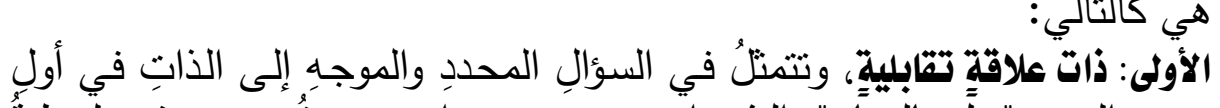

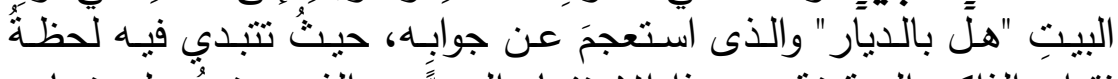

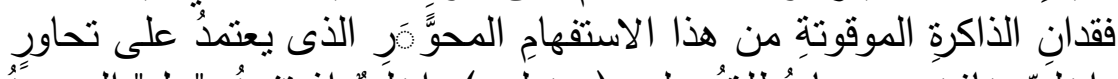

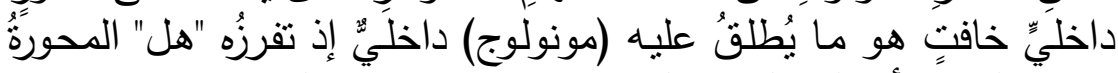

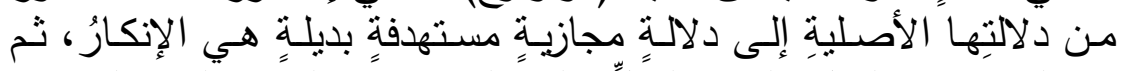

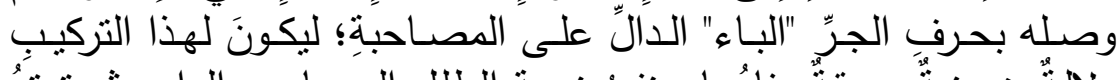

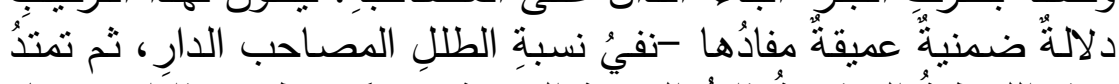

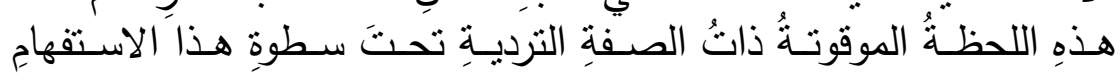

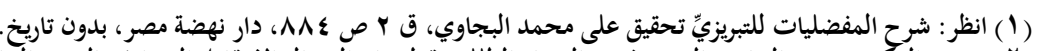

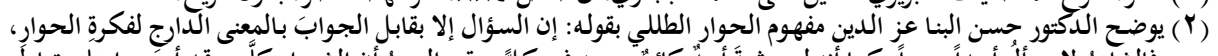

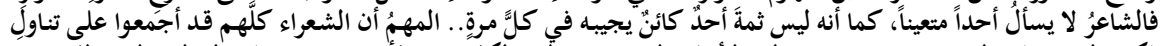

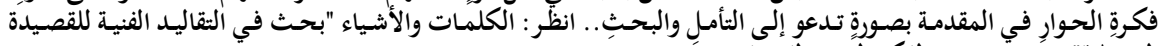

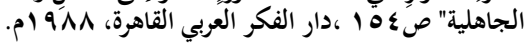




\section{المقدمة الطليلة في شعر المرقش الأكبر - دراسة تحليلية ونقدية}

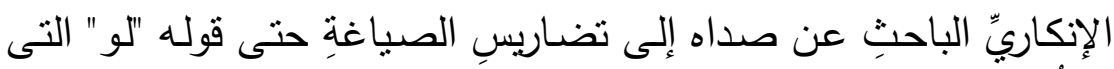

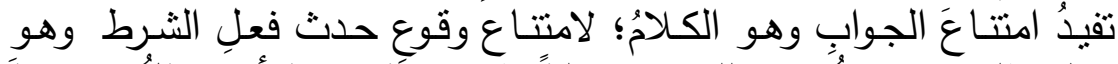

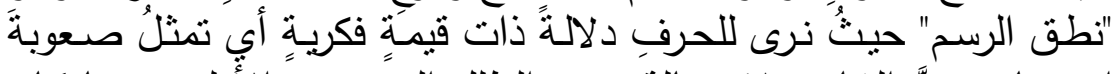

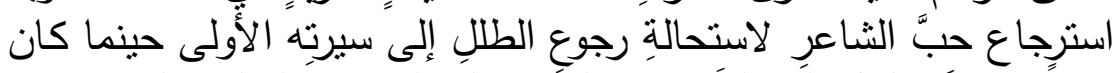

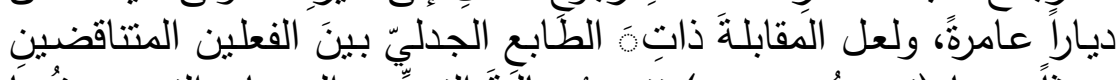

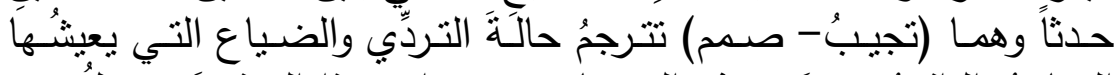

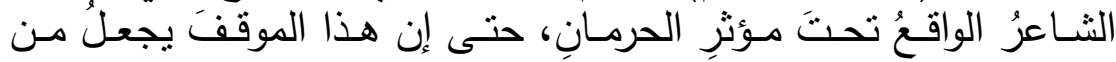

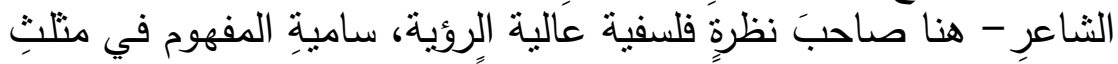

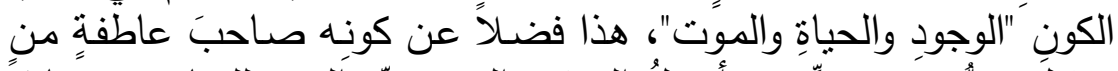

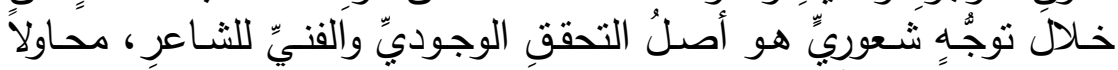

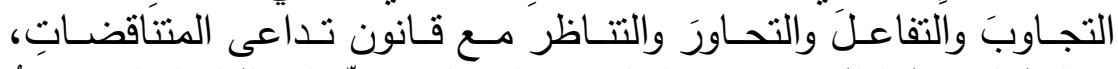

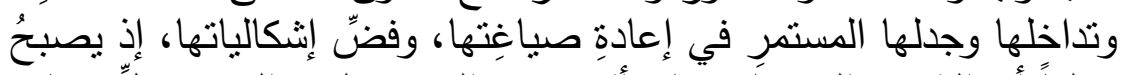

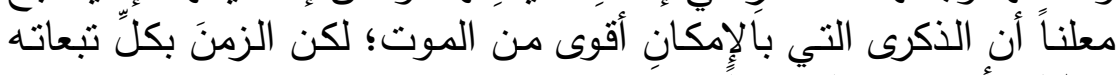

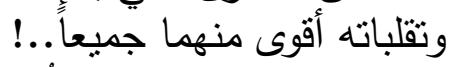

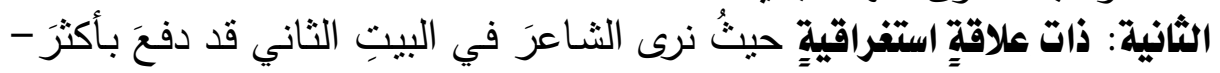

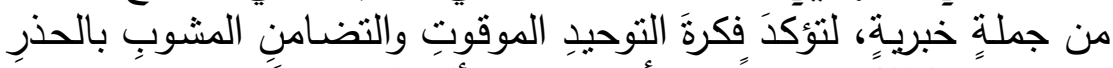

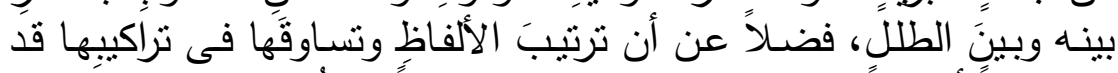

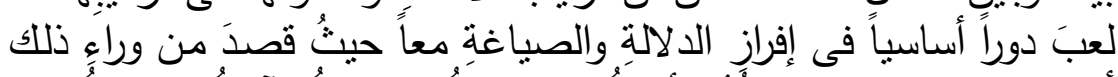

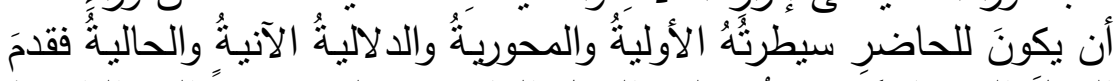

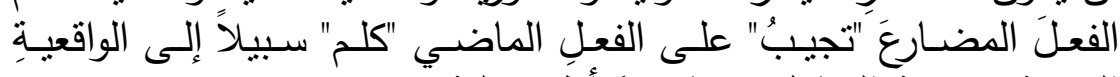

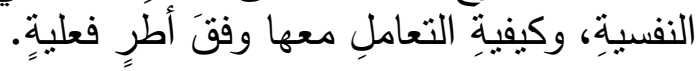

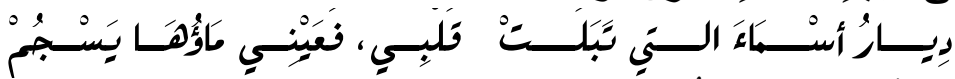

وننظرُ إلى البيتِ الثالثِ فنرى قولَهِ

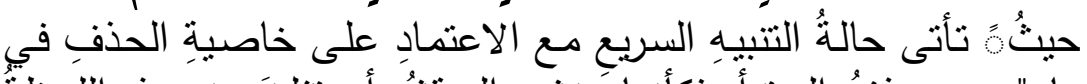

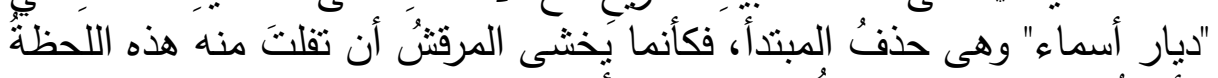

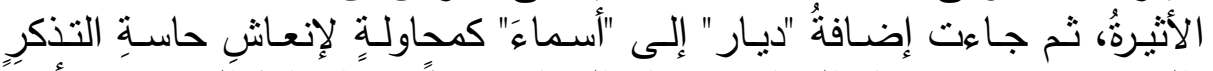

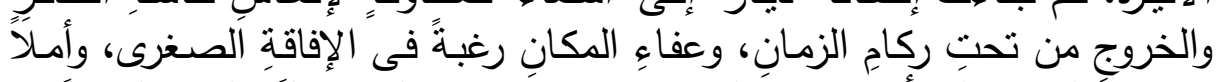

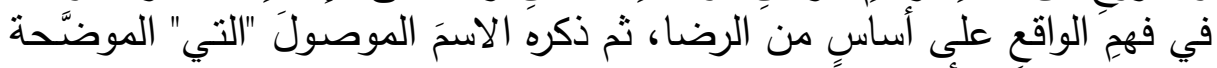

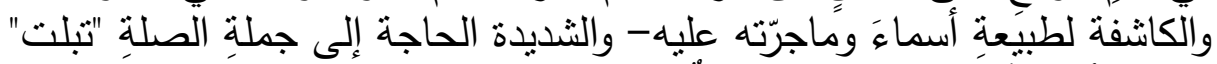

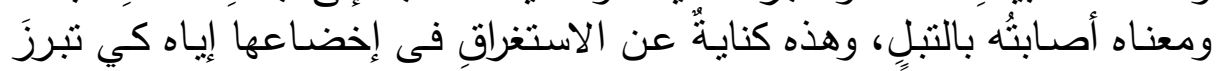

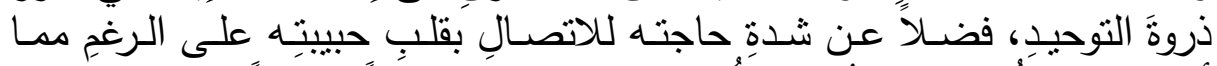

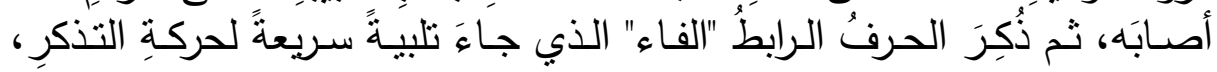




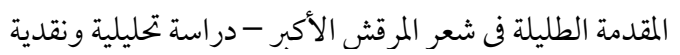

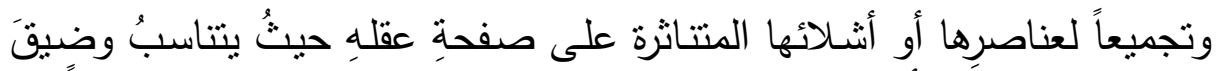

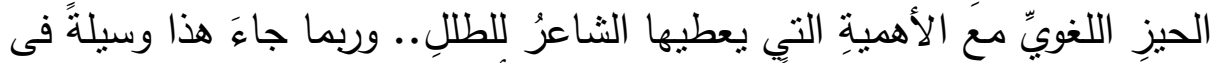

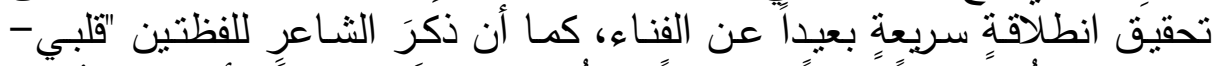

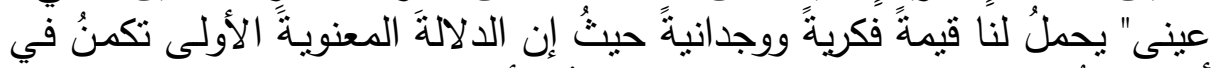

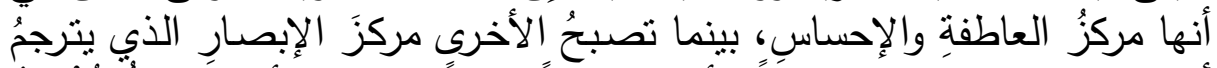

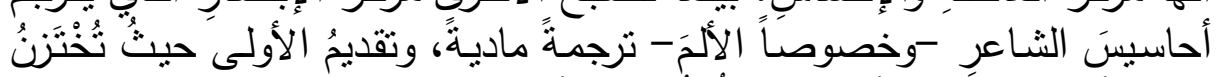

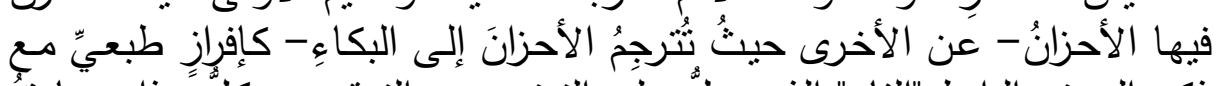

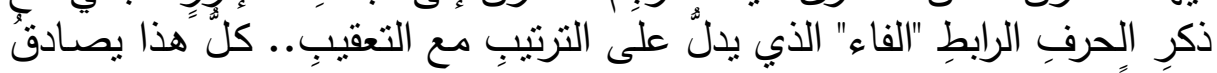

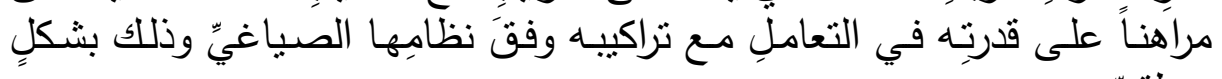

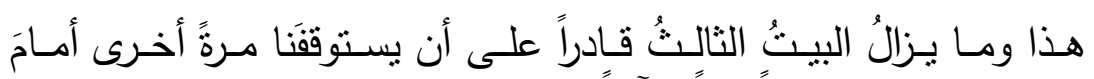
منطقيٍٍ مراهِ

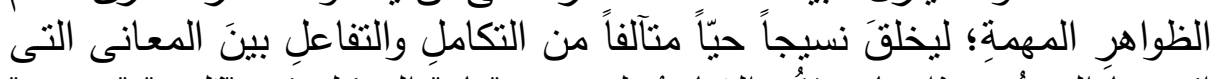

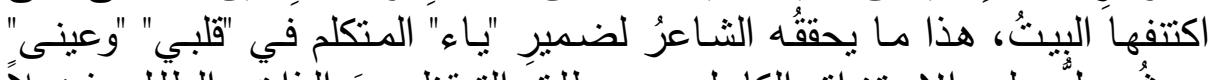

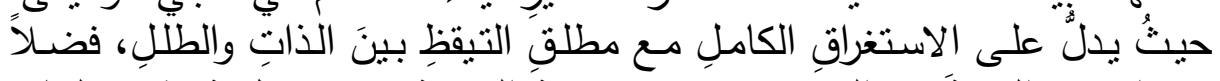

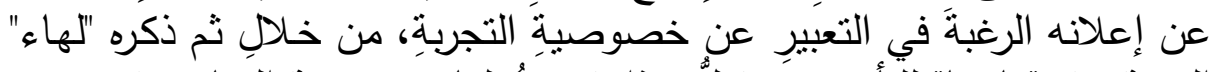

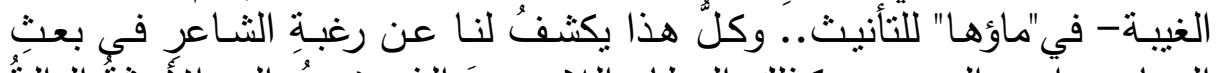

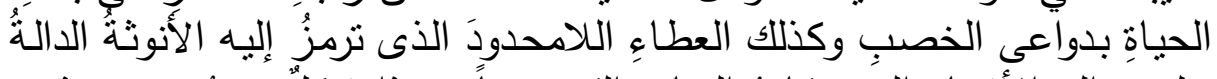

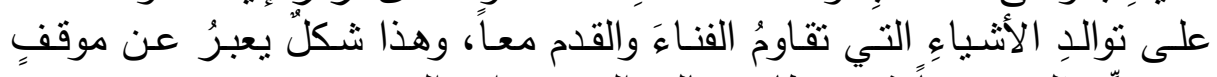

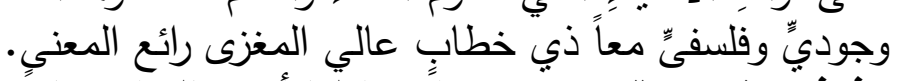

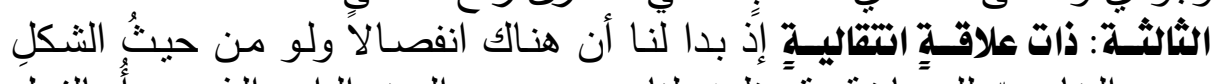

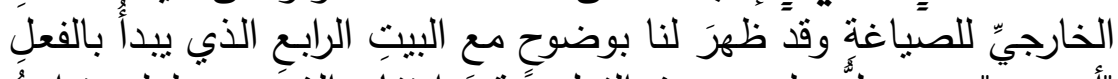

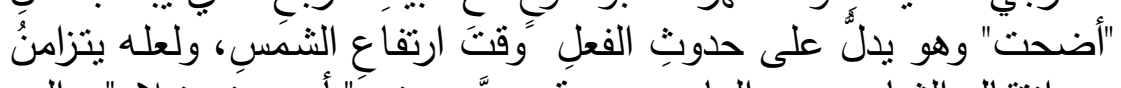

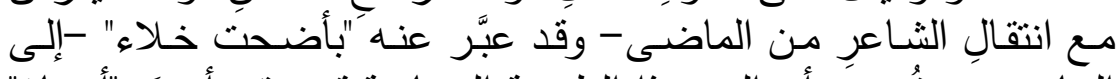

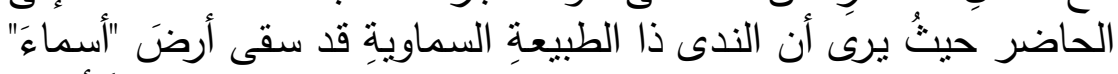

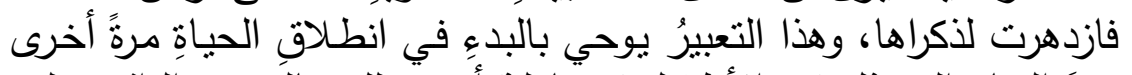

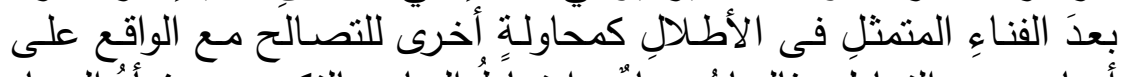

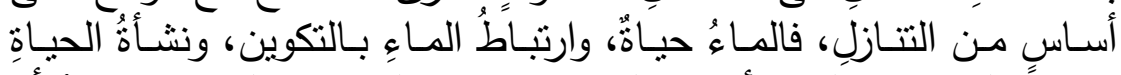

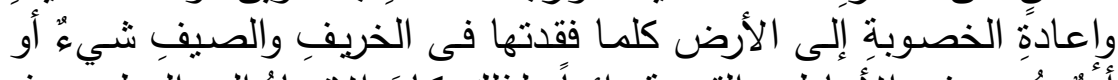

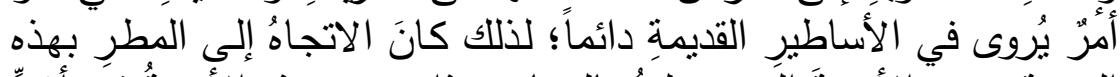

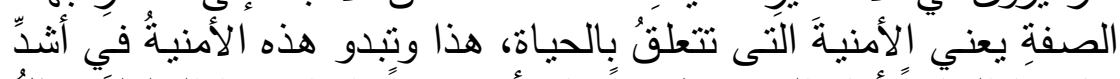

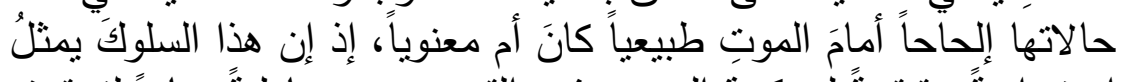

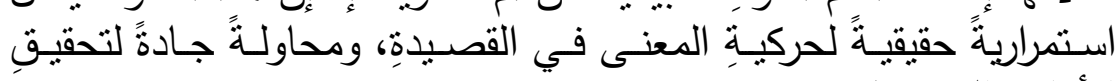

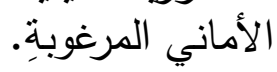




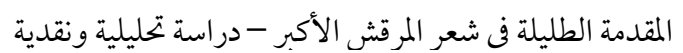

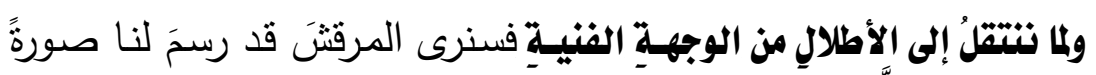

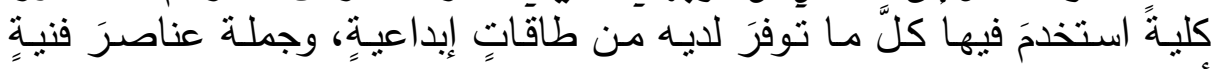
أخرى نذكر منها:

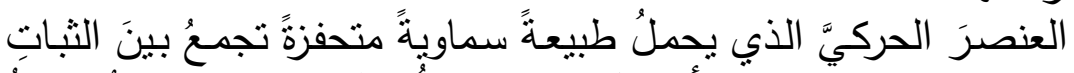

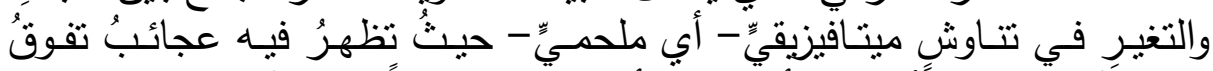

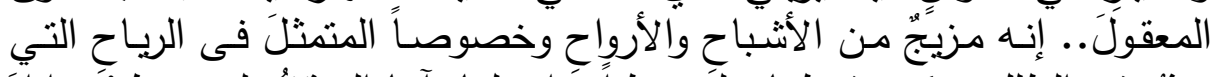

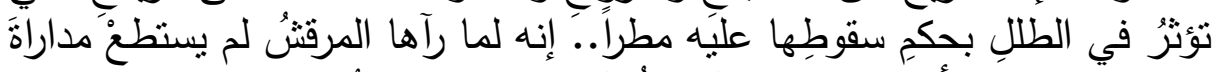

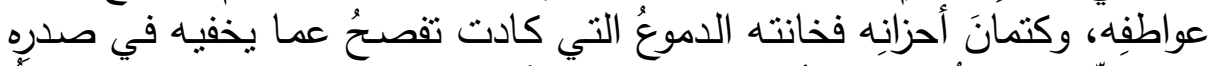

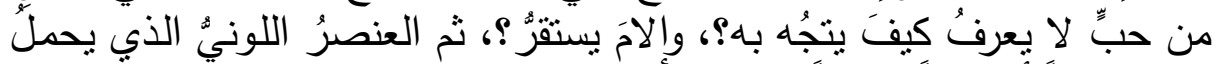

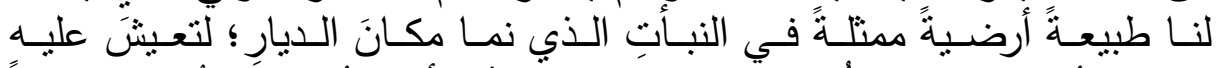

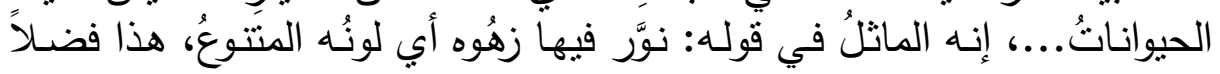

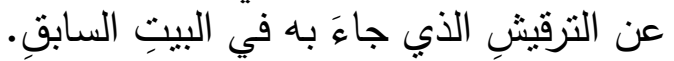

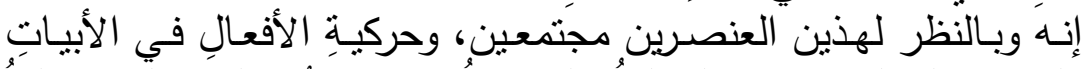

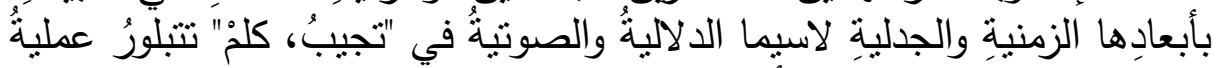

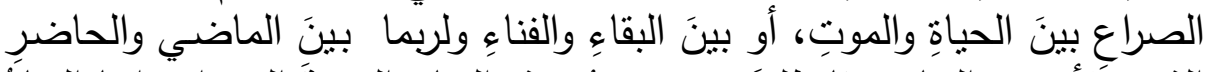

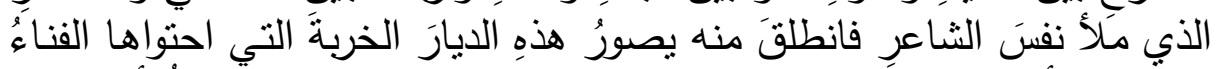

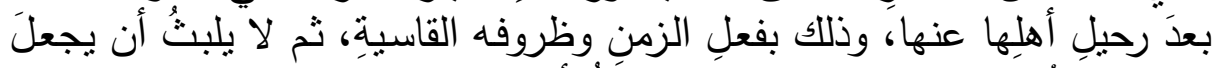

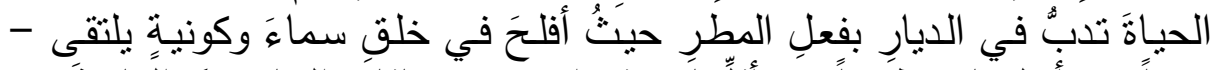

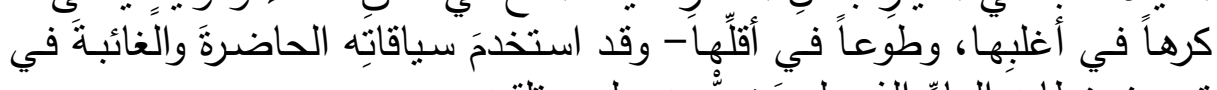

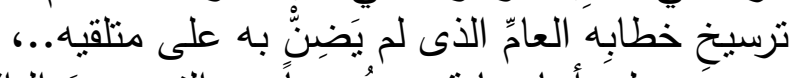

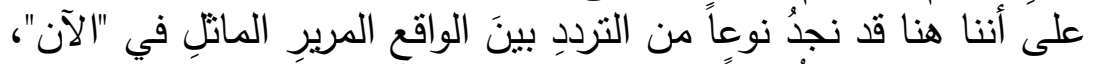

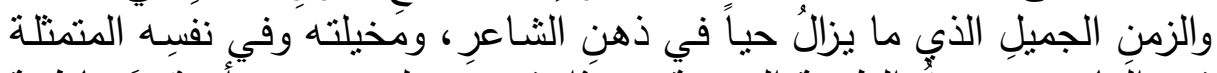

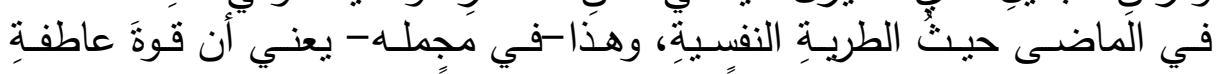

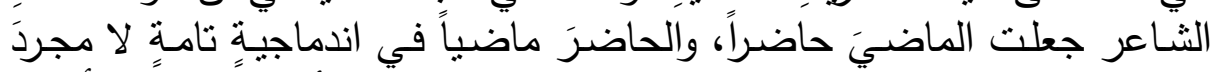

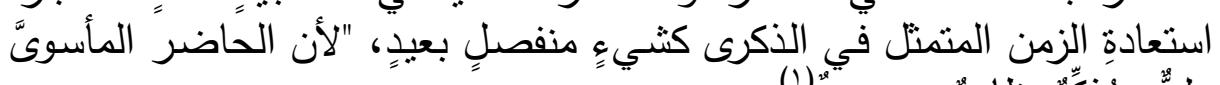

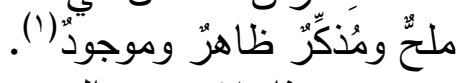

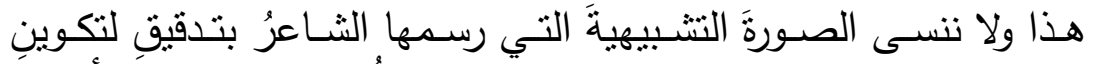

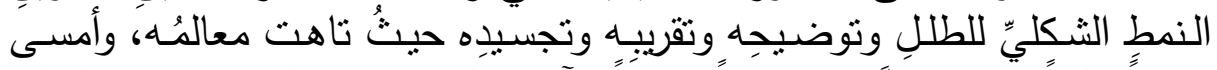

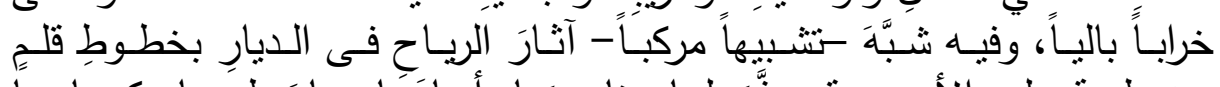

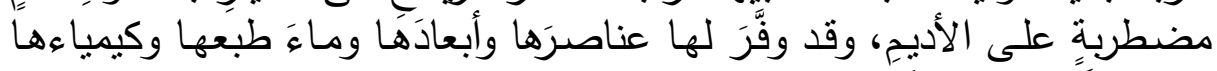

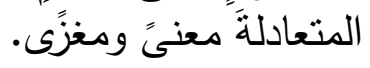




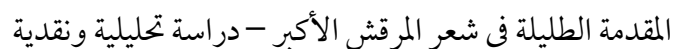

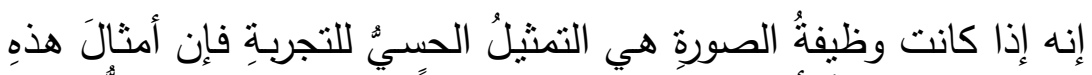

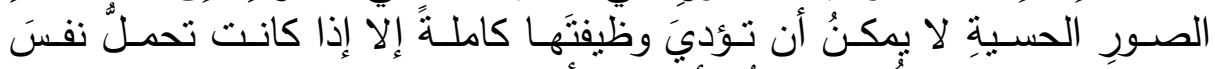

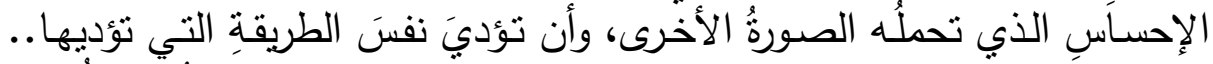

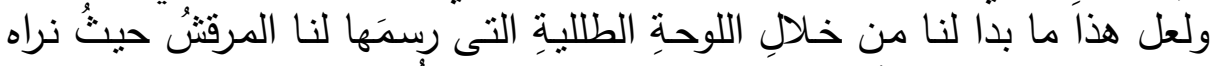

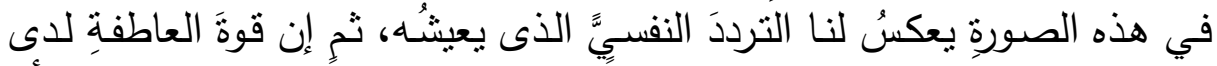

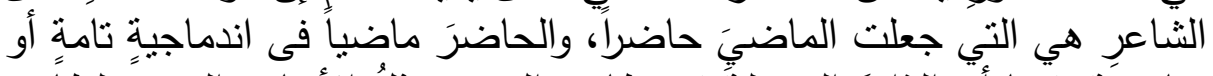

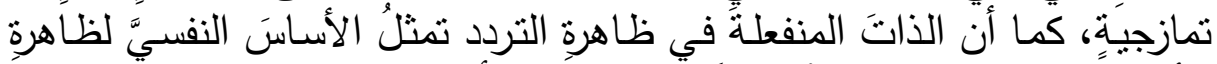

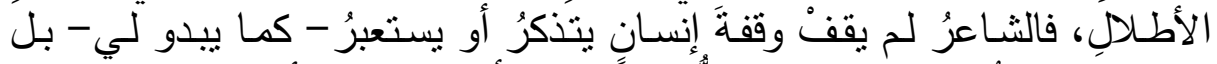

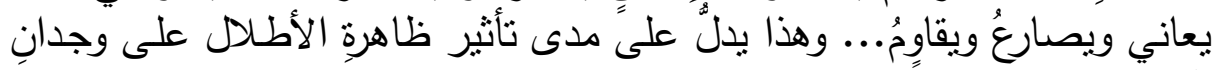
الثاعر ونفسيتِه وعاً.

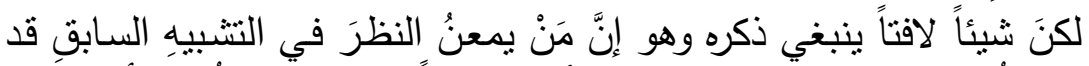

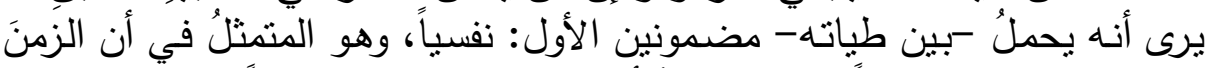

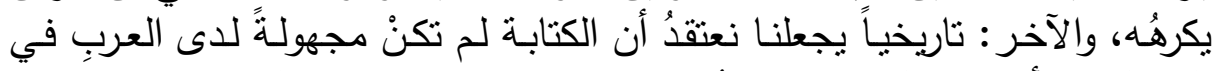

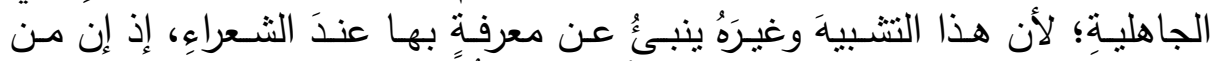

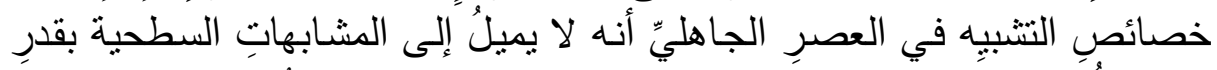

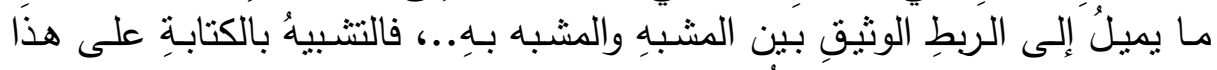

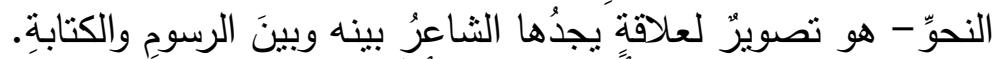

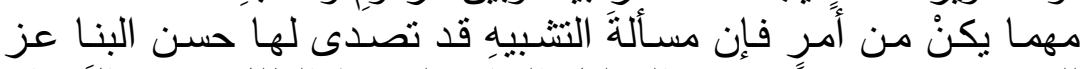

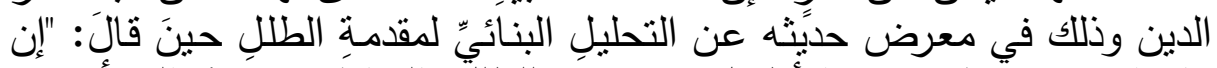

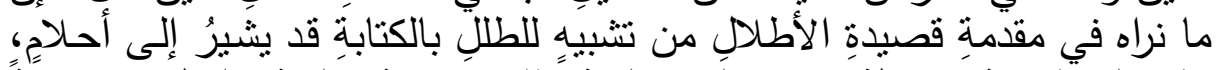

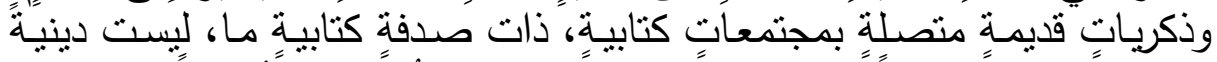

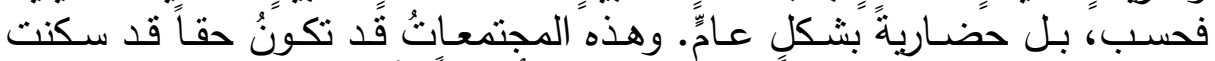

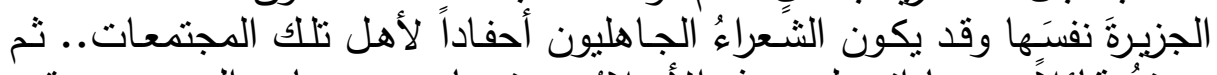

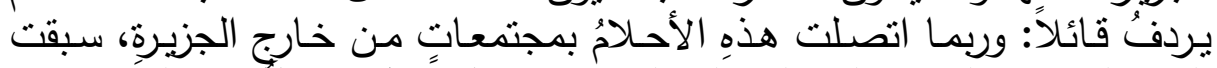

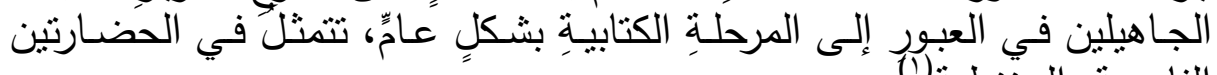

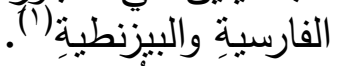

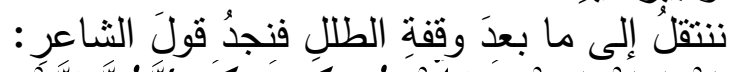

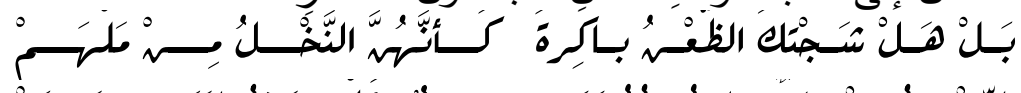

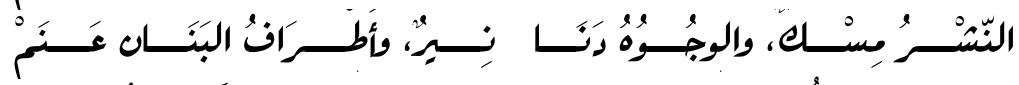

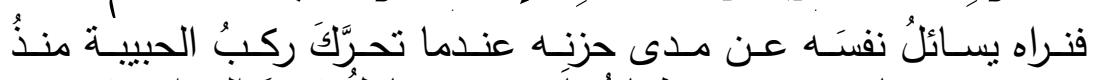

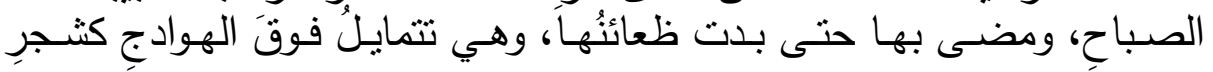




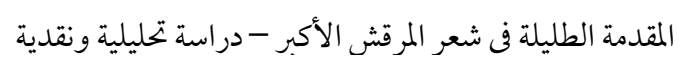

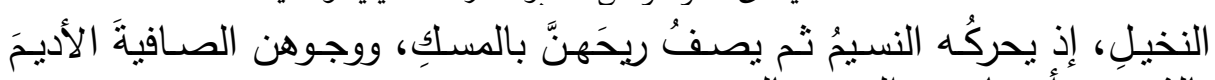

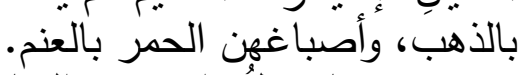

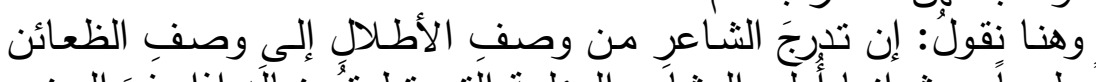

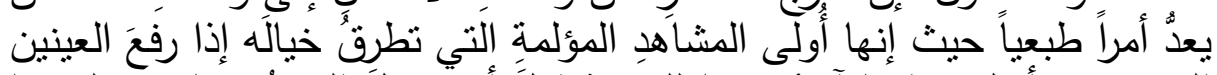

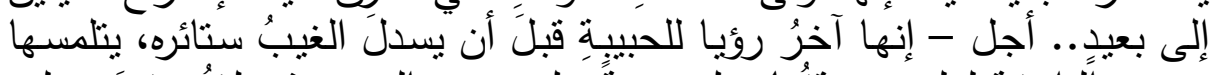

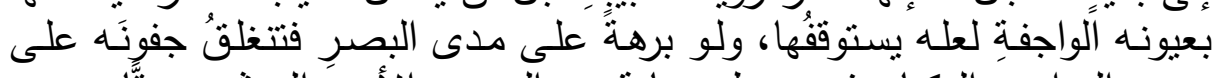

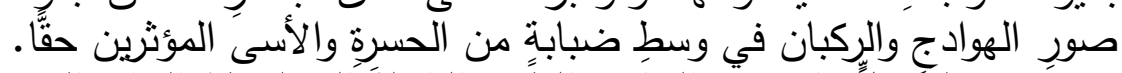

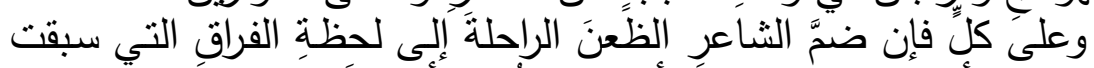

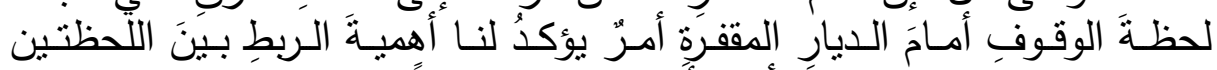

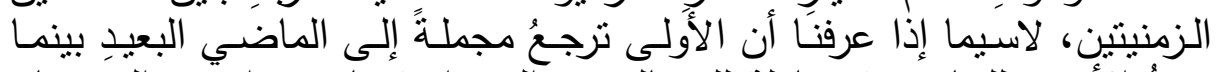

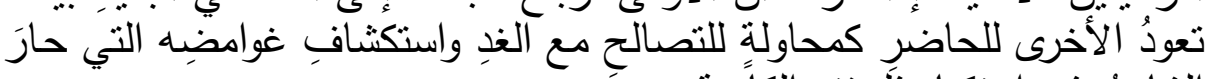

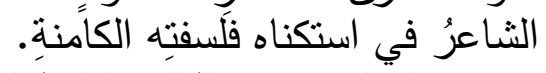

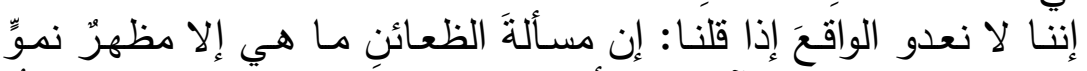

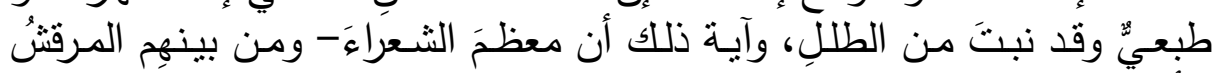

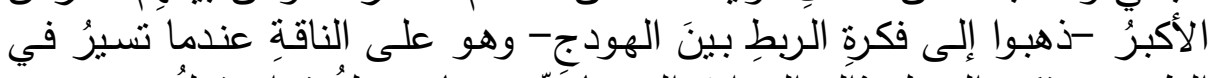

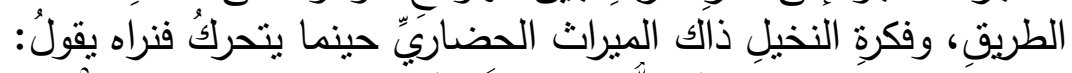

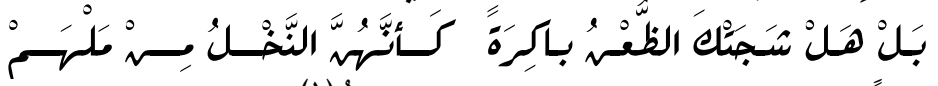

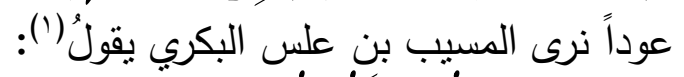

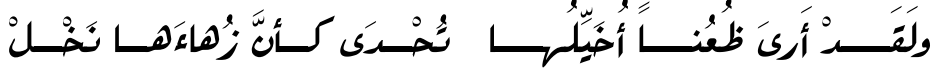

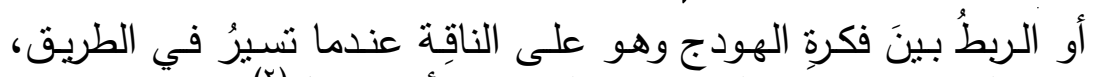

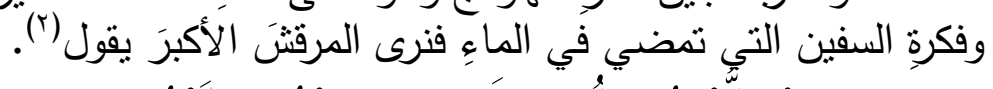

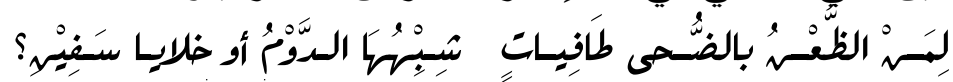

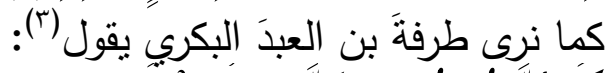

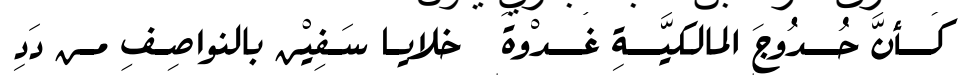

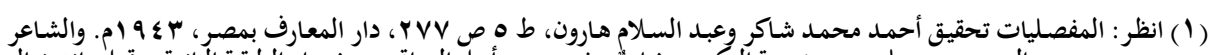

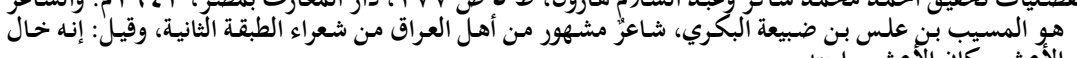

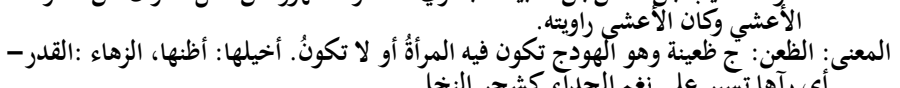

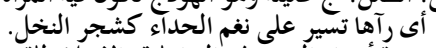

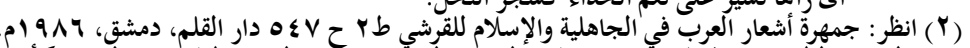

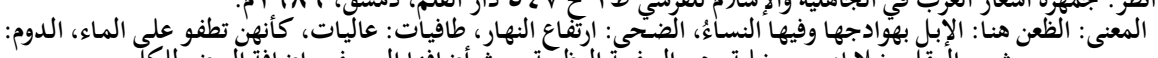

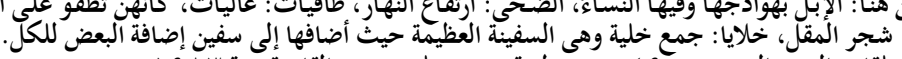

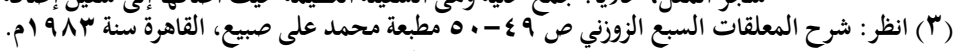

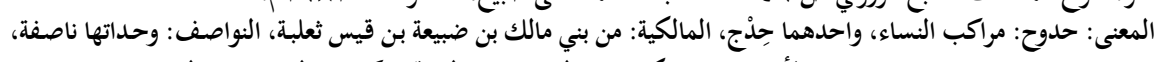

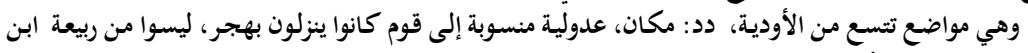

يامن: ملاح من أهل هجر من ماضع. 


\section{المقدمة الطليلة فى شعر المرقش الأكبر - دراسة تحليلية ونقدية}

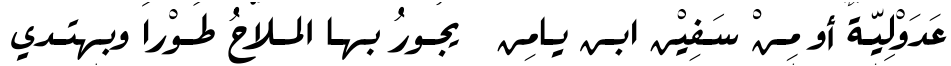

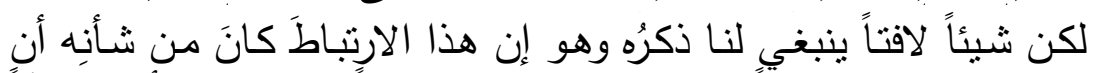

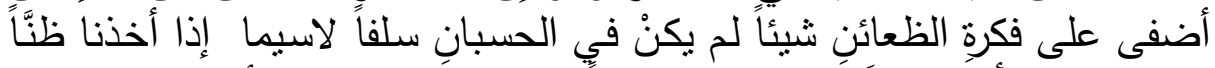

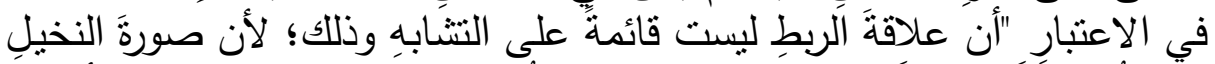

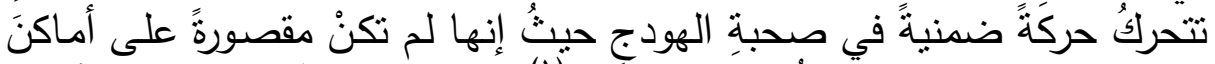

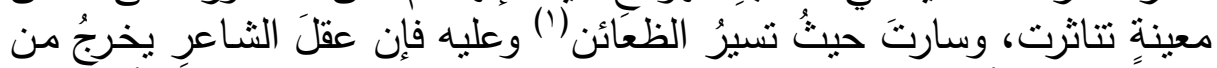

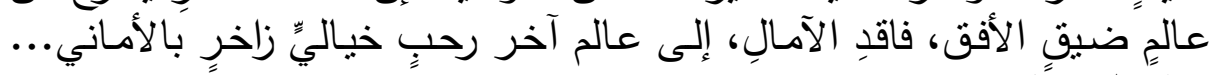

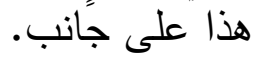

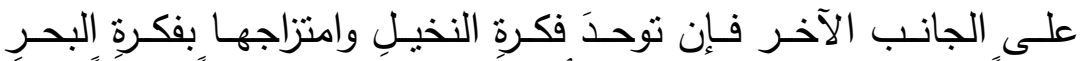

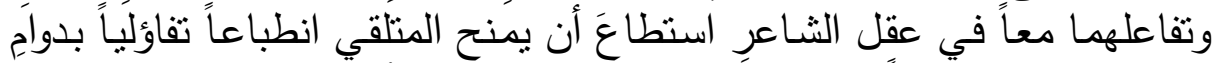

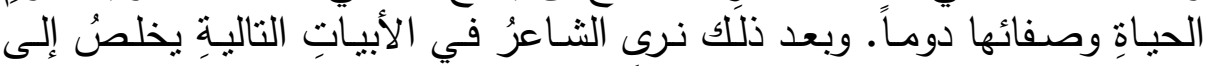

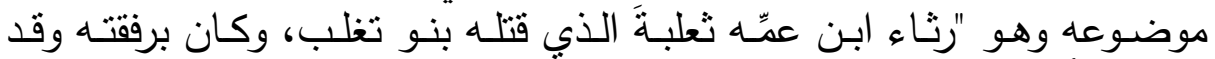

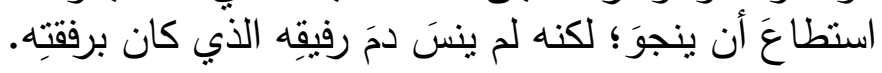

\section{القصيلدة الثانية: (هل تعرف الدار):}

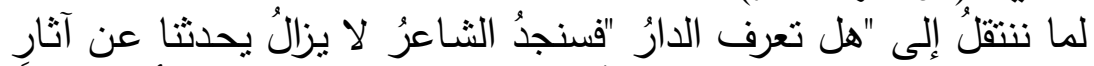

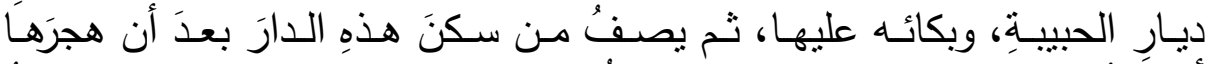

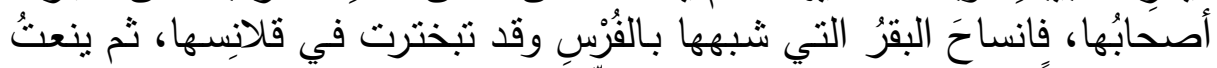

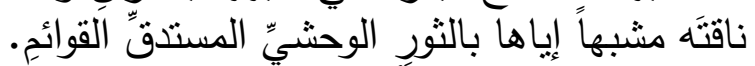

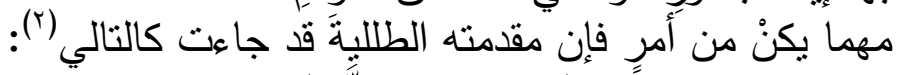

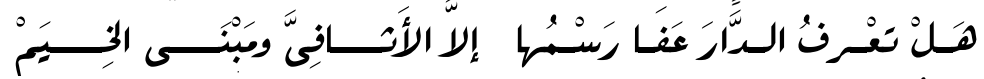

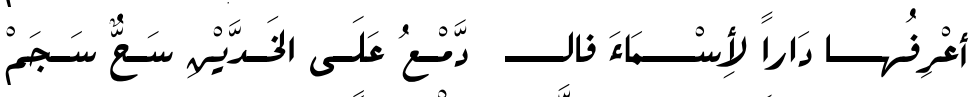

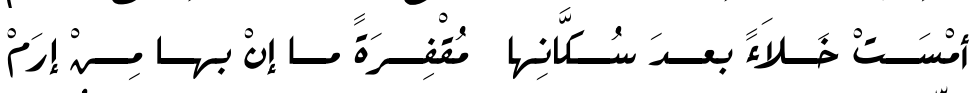

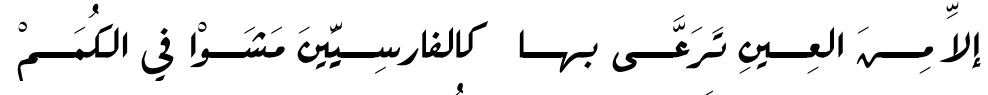

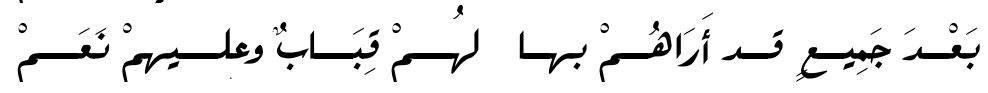

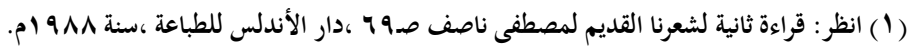

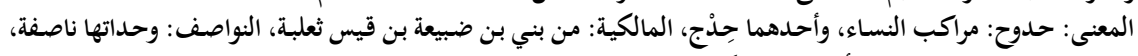

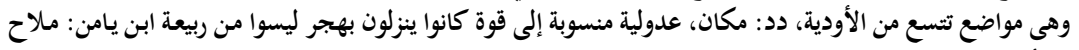
من أهل هجر.

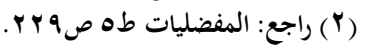

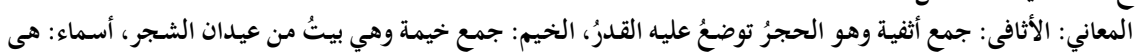

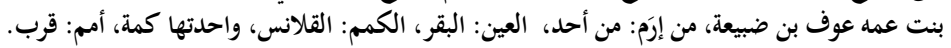




\section{المقدمة الطليلة فى شعر المرقش الأكبر - دراسة تحليلية ونقدية}

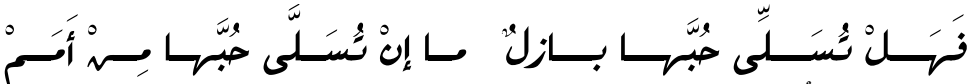

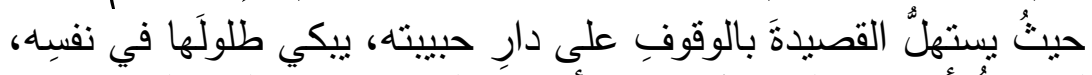

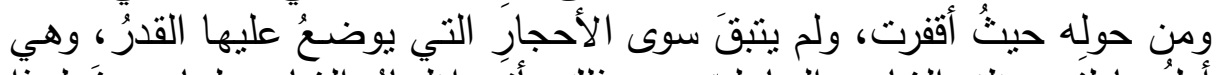

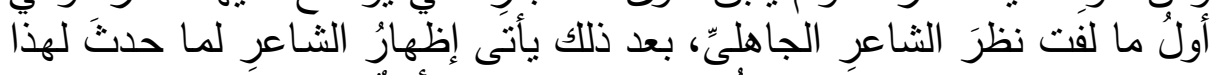

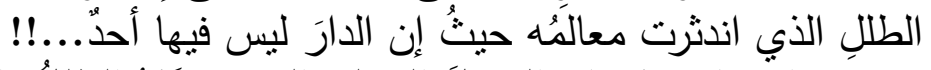

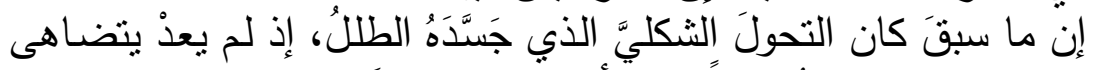

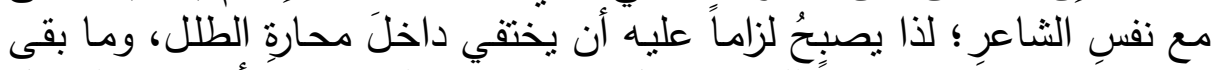

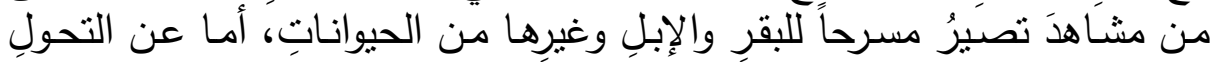

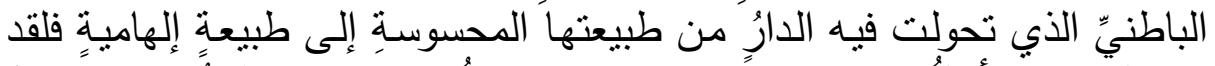

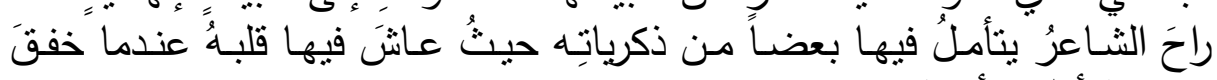
خفقته الأولى لأسماء.

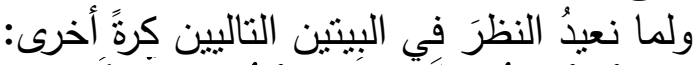

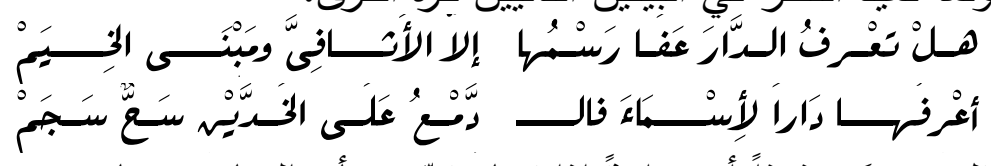

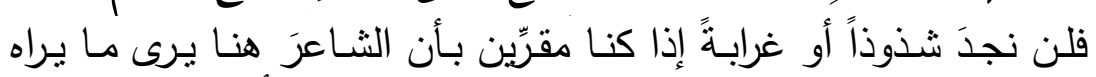

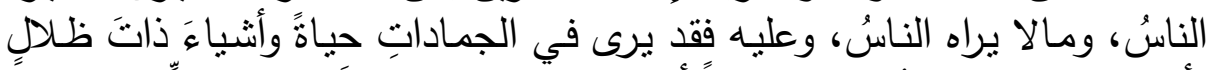

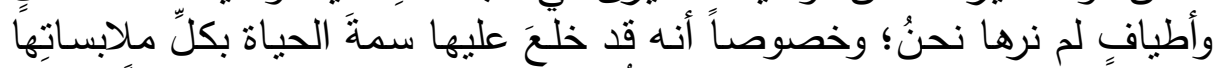

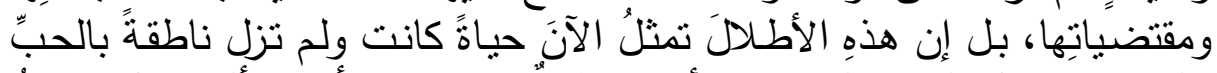

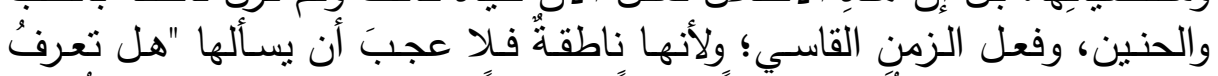

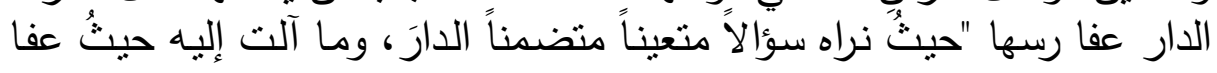

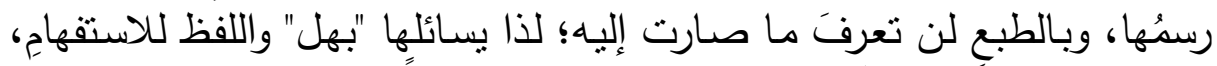

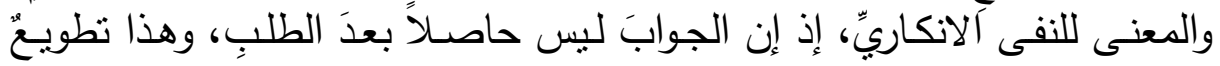

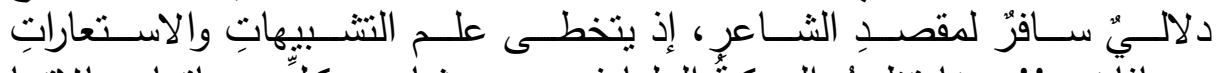

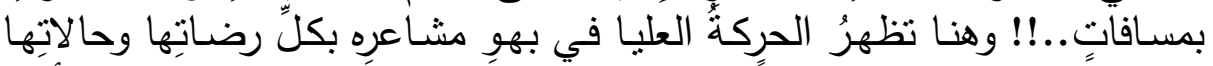

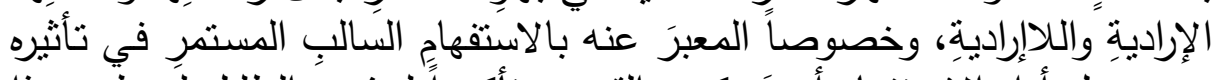

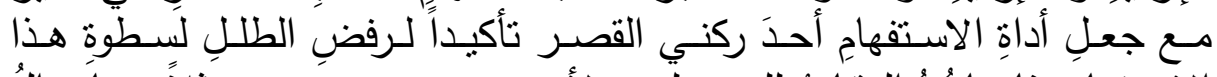

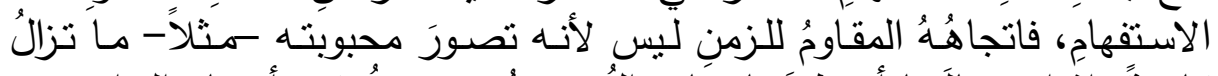

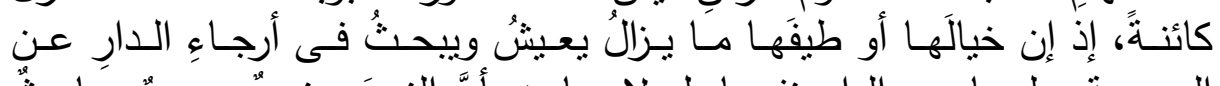

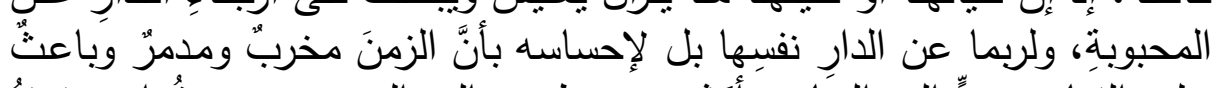

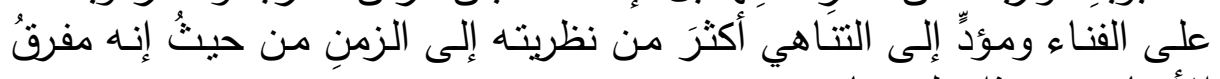

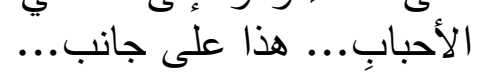




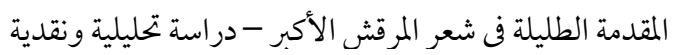

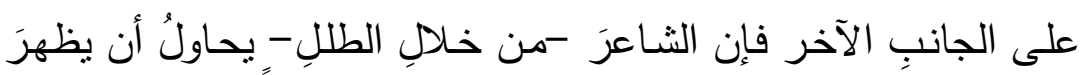

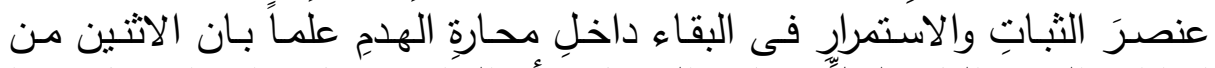

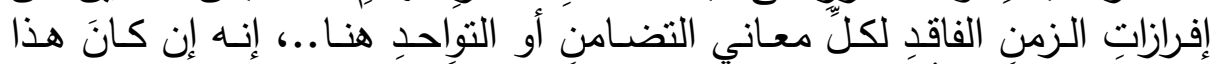

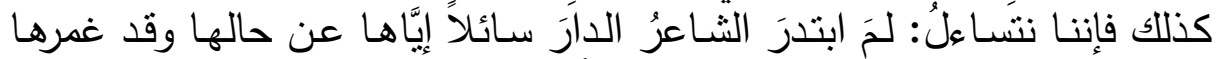

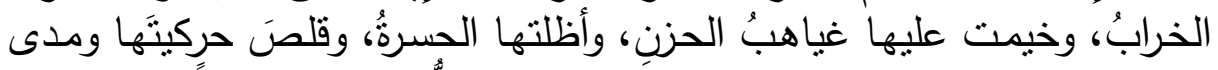

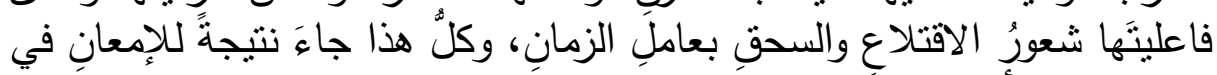

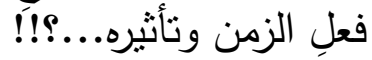

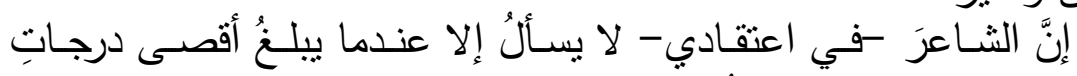

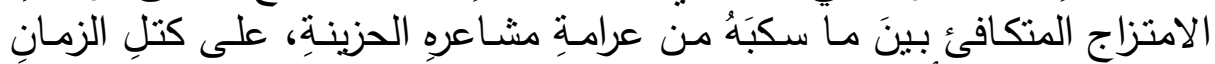

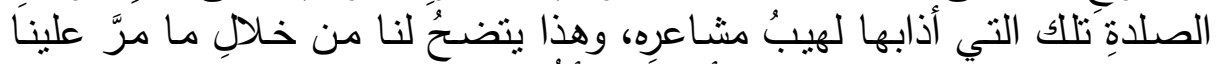

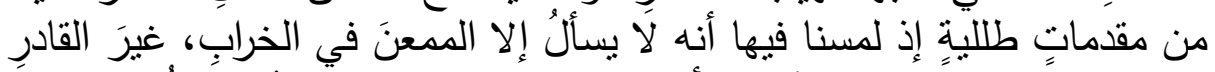

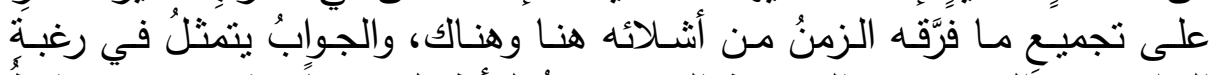

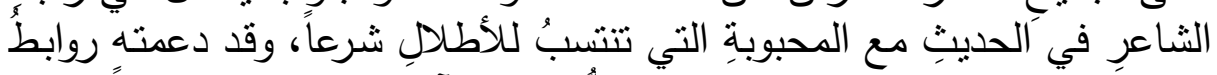

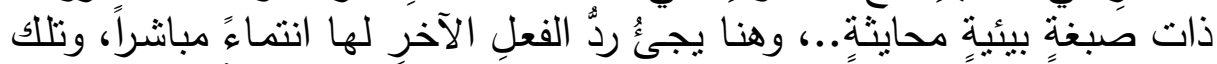

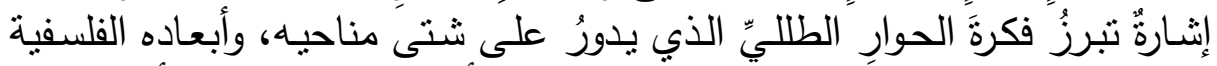

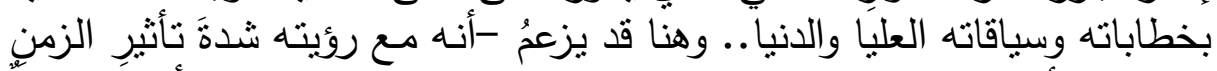

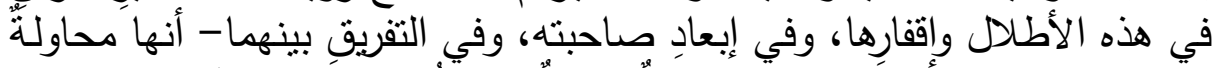

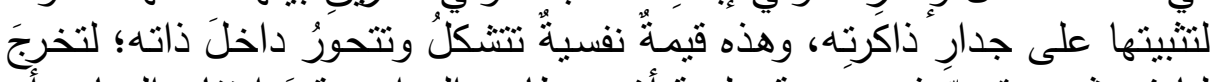

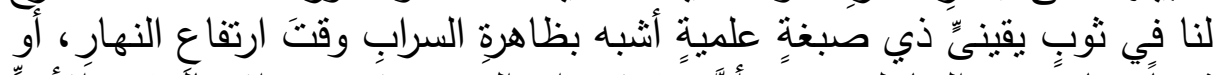

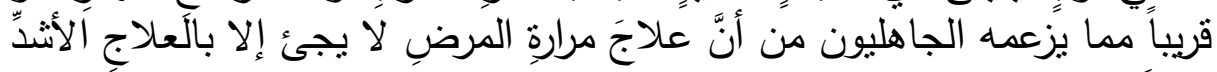

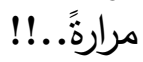

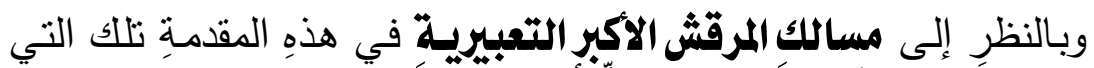

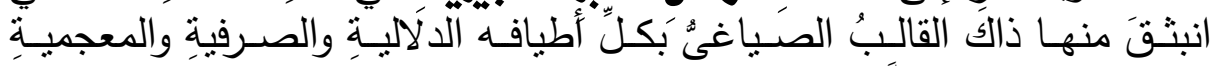

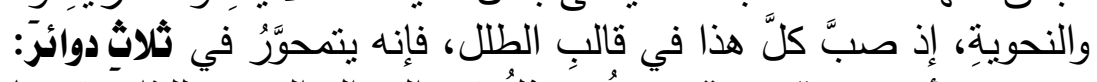

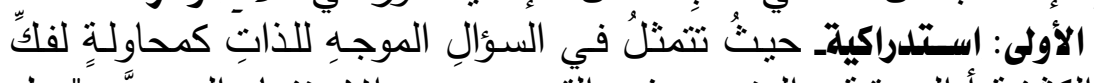

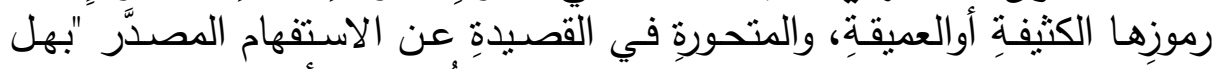

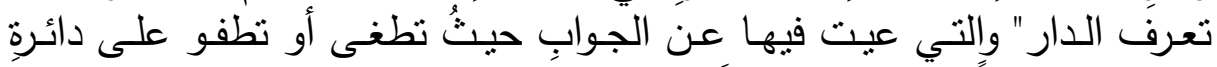

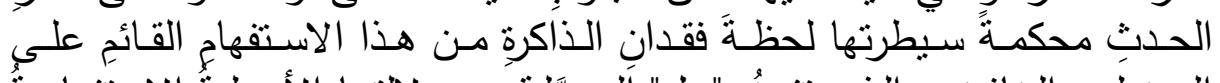

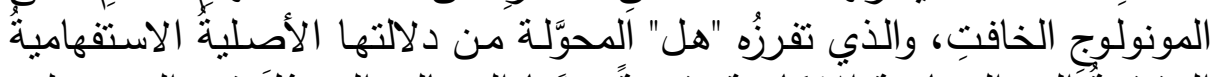

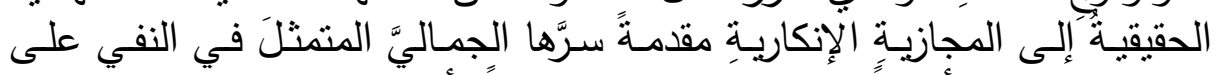

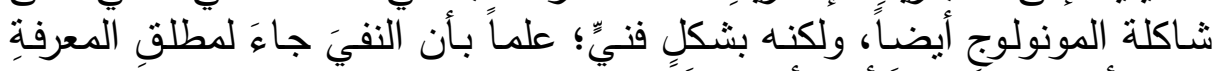

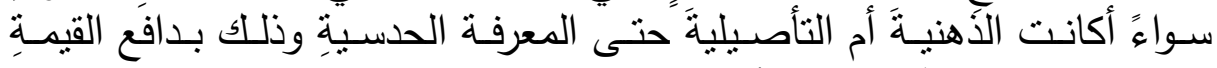

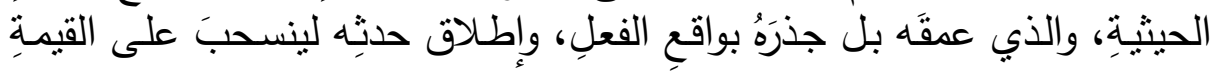




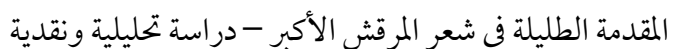

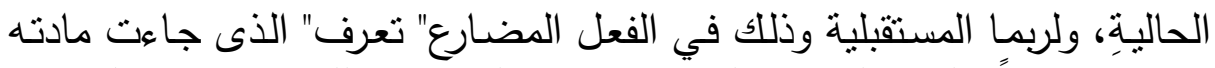

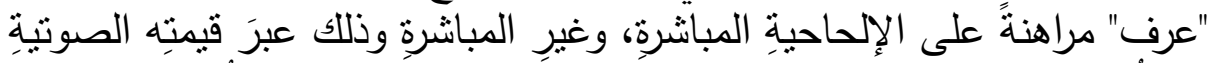

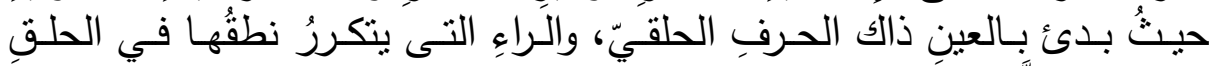

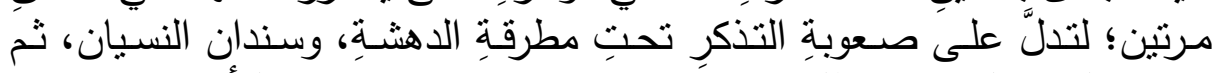

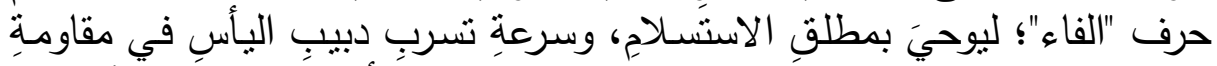

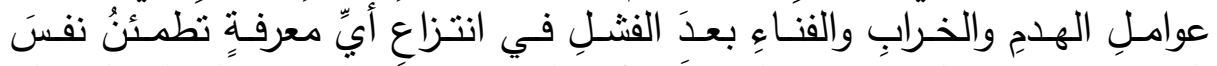

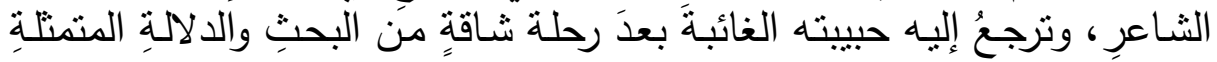

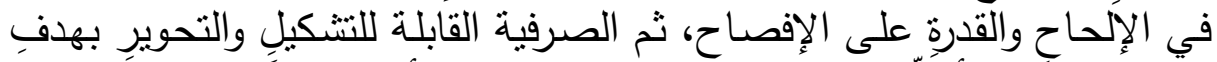

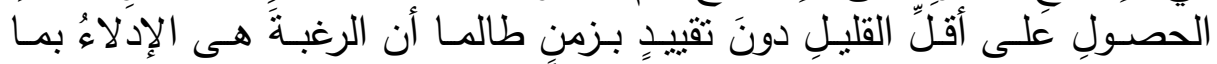

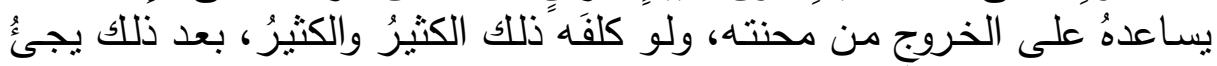

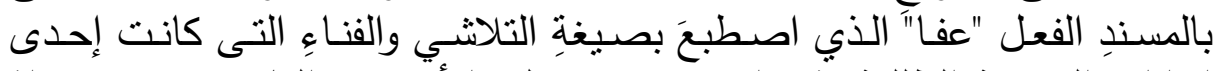

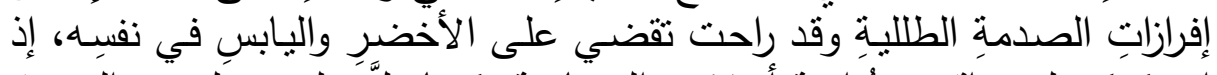

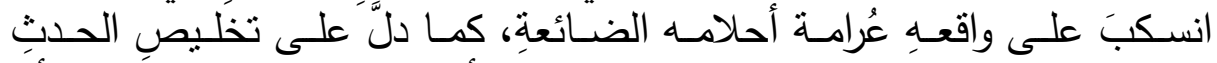

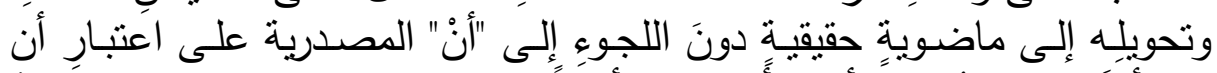

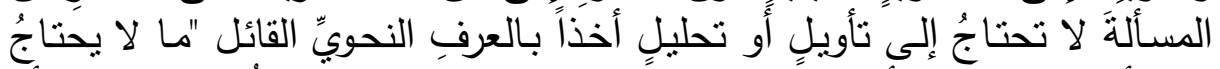

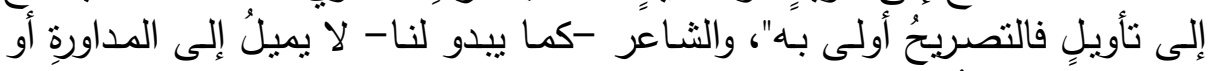

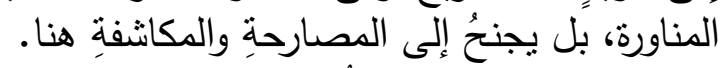

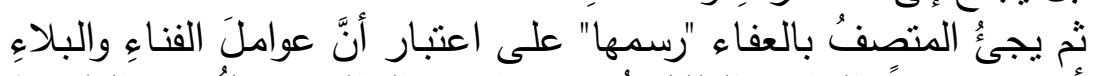

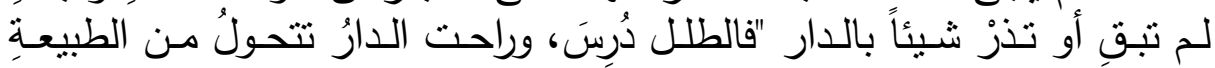

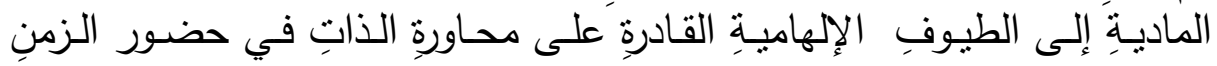

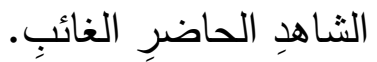

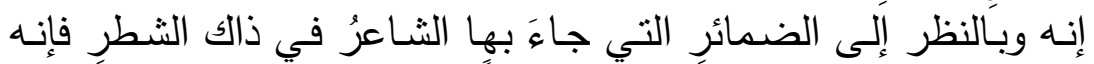

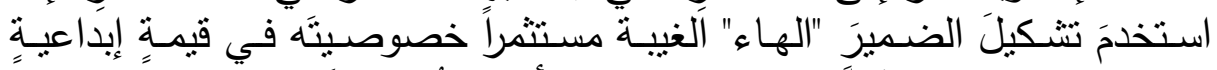

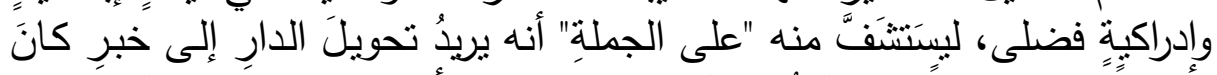

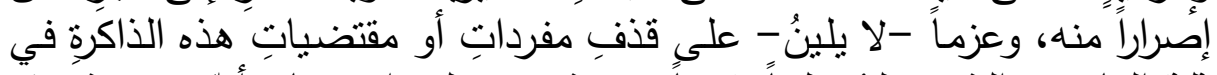

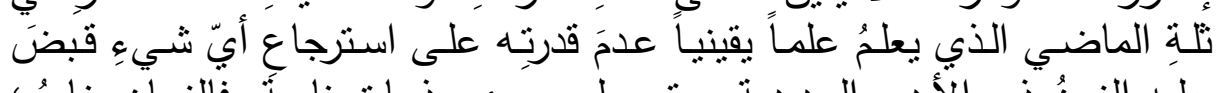

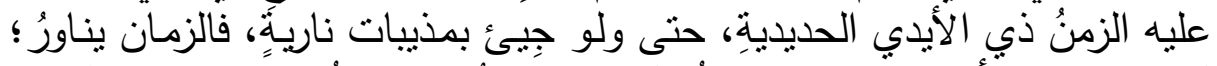

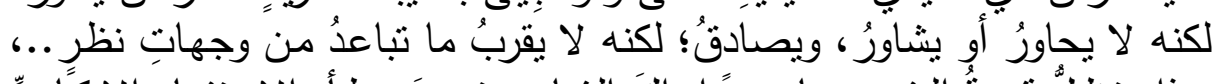

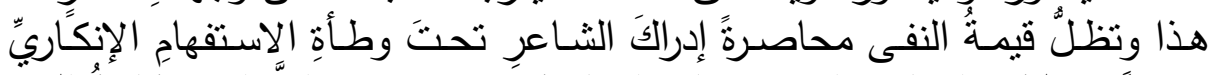

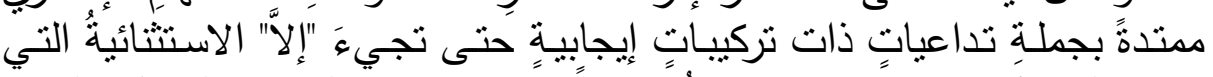

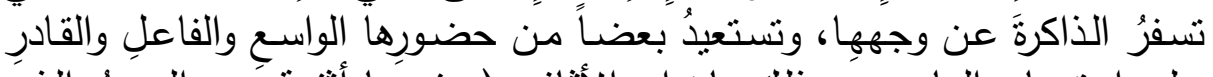

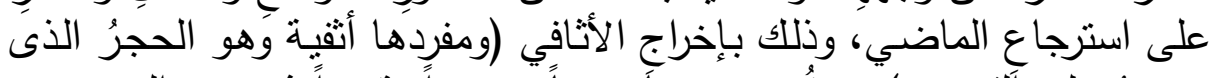

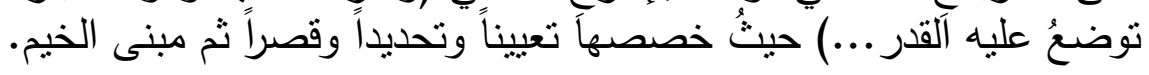




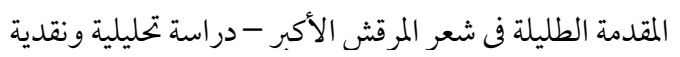

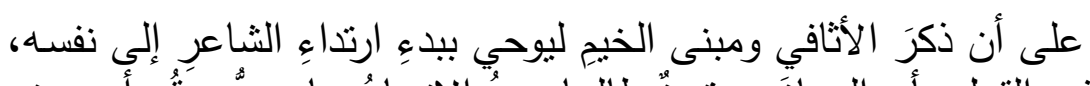

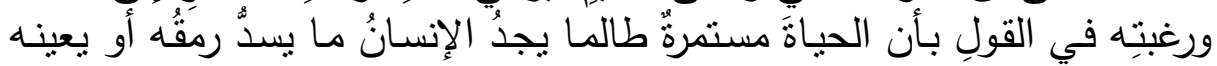

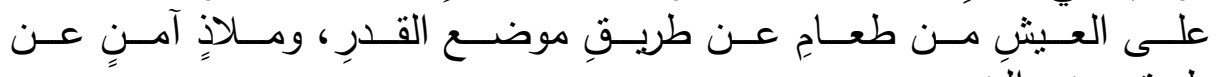

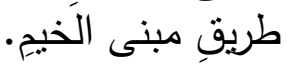

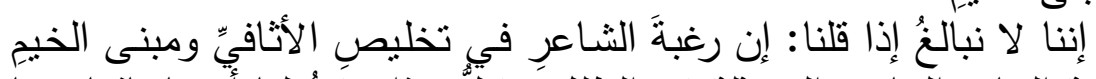

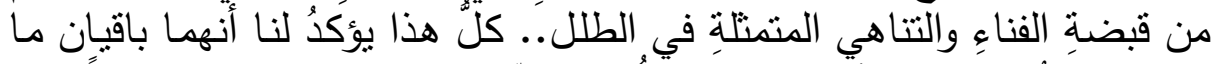

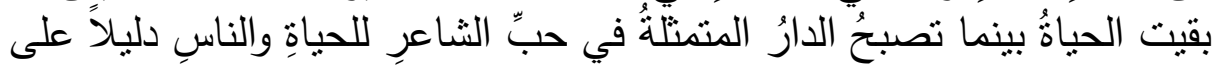

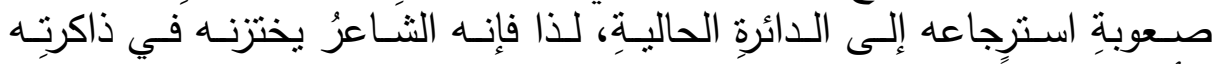

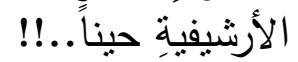

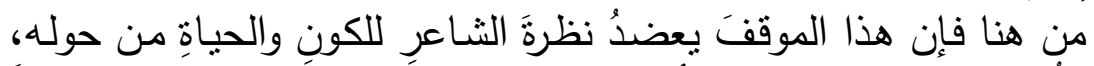

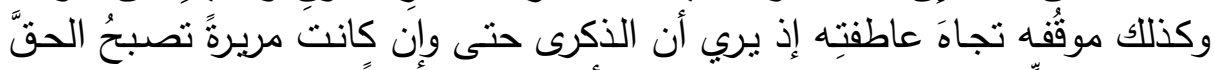

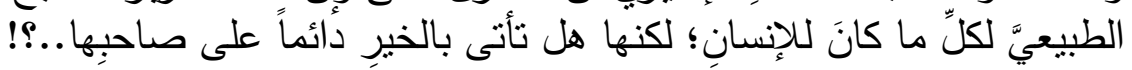

\section{الثانية ذات علاقةٍ تردديةٍ في قوله :}

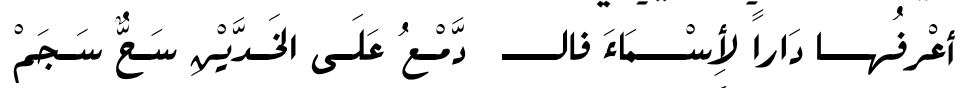

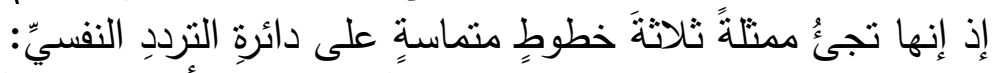

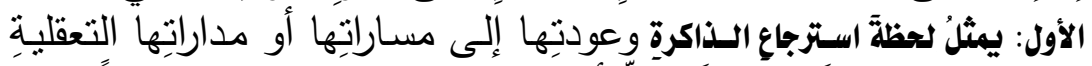

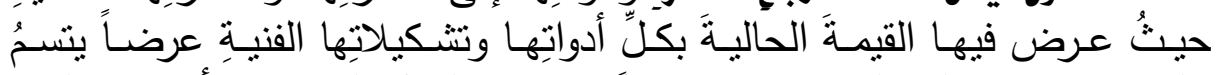

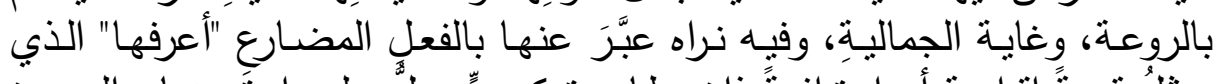

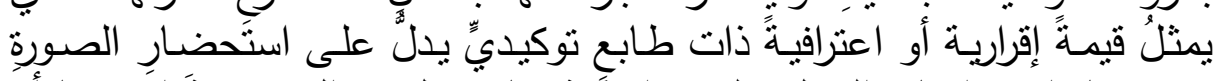

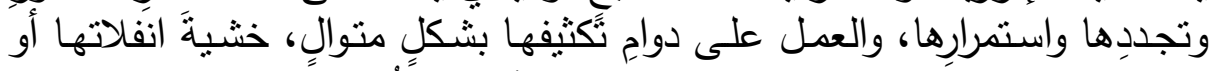

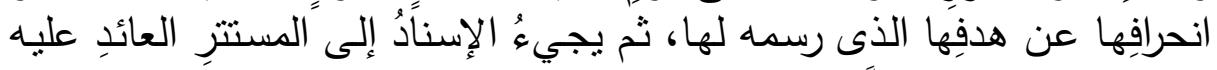

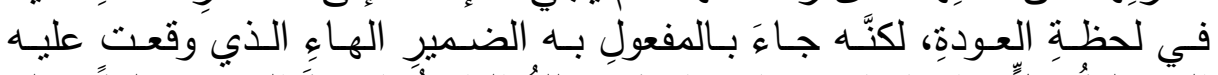

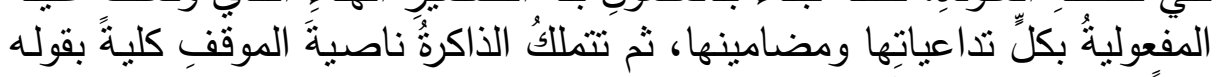

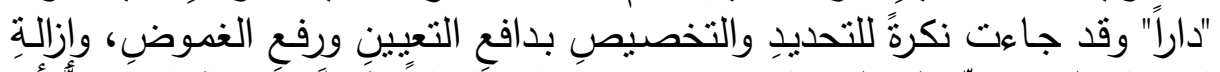

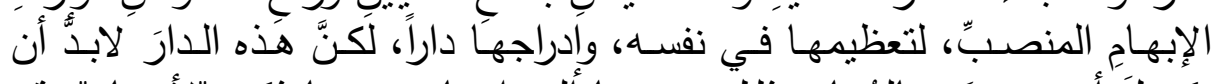

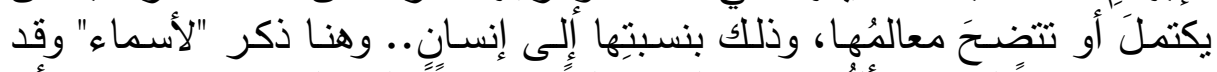

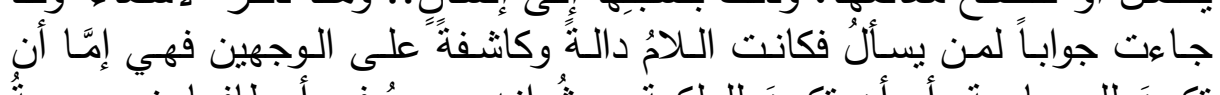

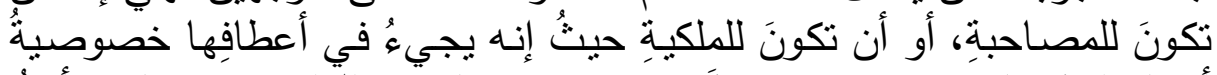

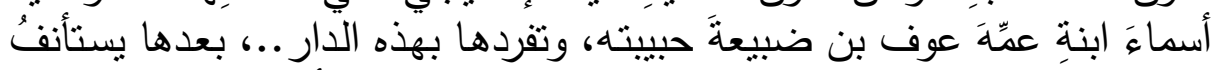

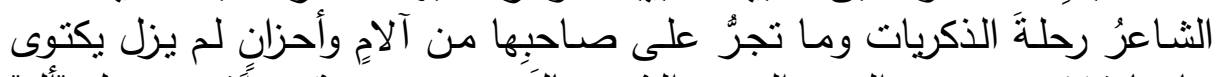

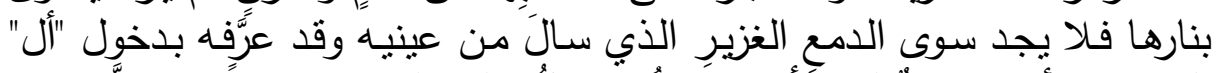

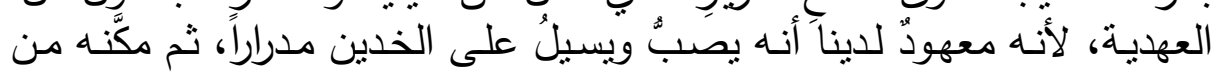




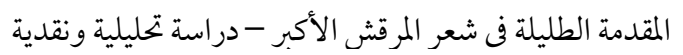

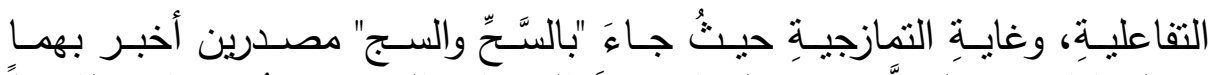

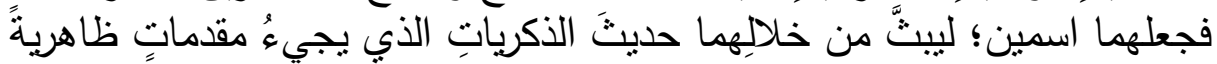

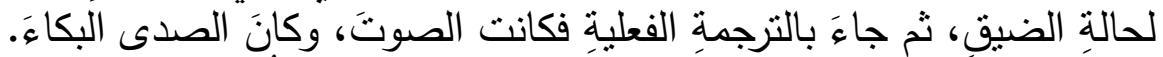

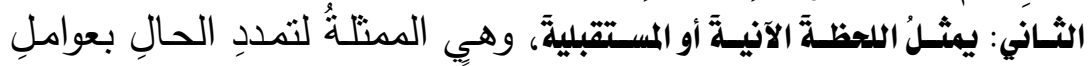

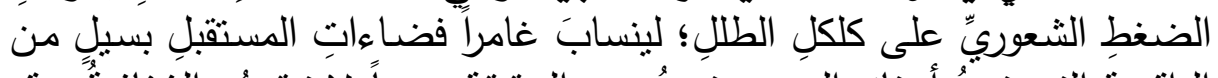

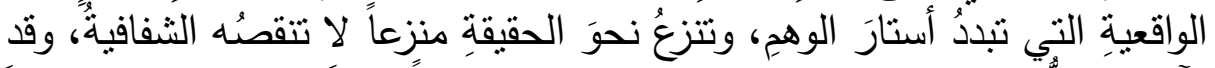

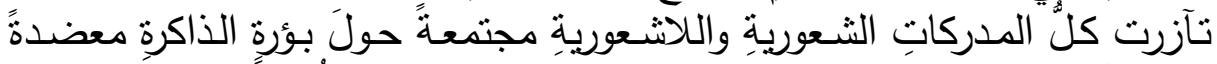

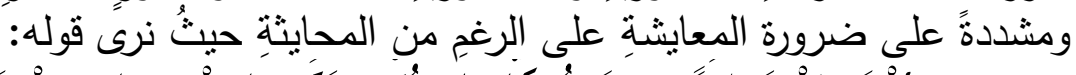

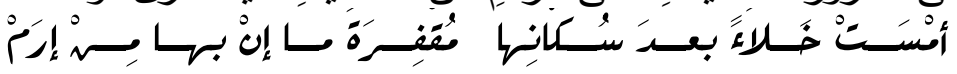

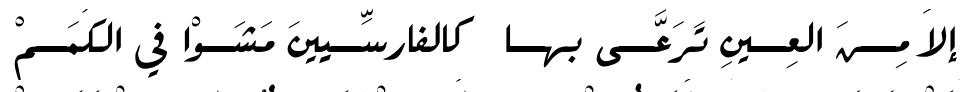

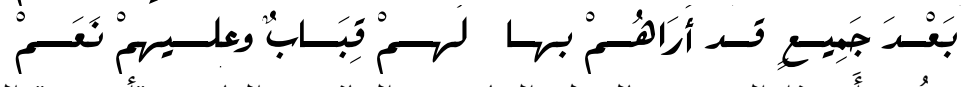

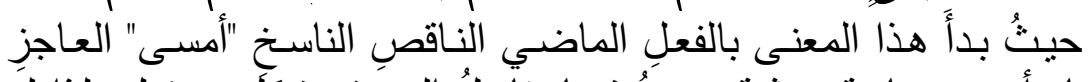

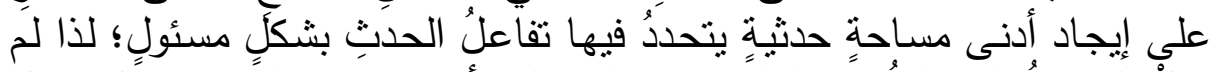

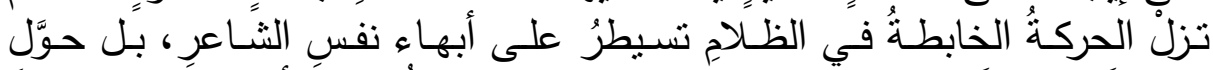

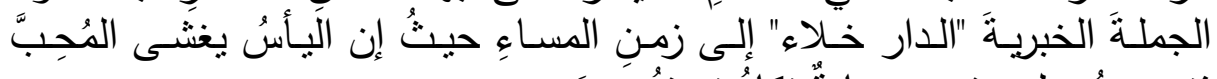

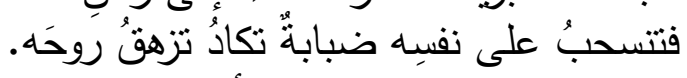

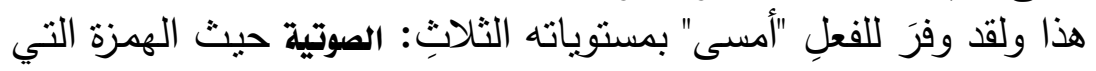

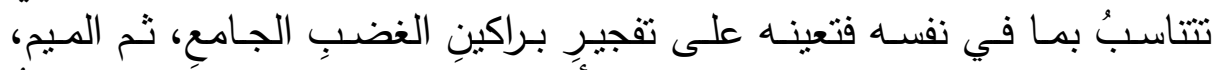

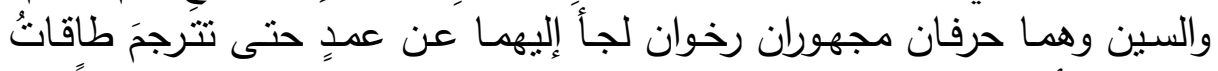

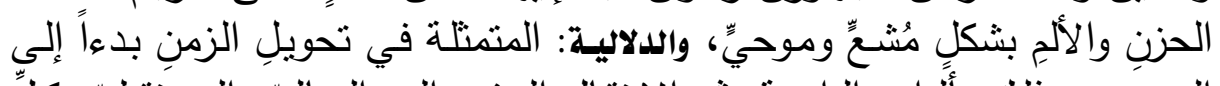

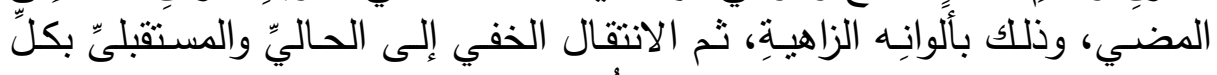

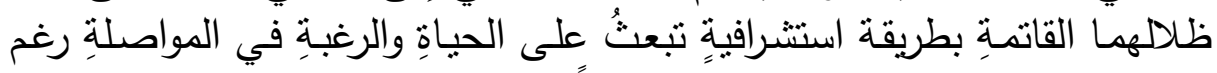

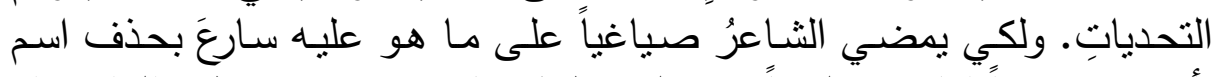

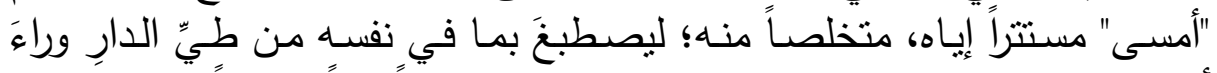

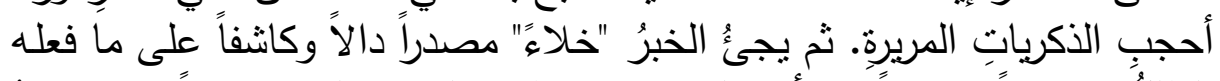

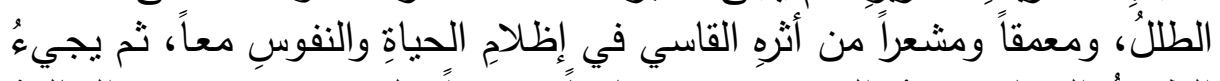

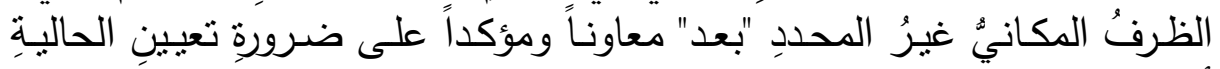

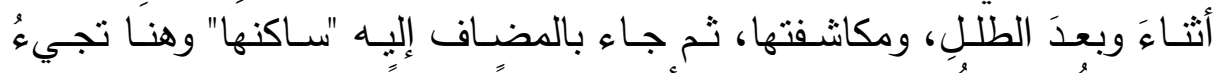

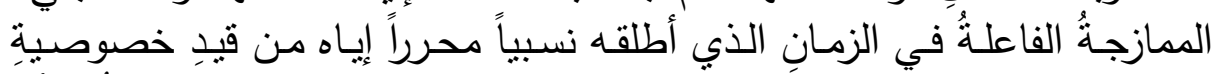

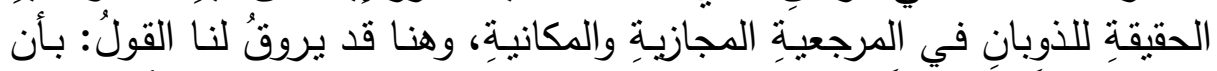

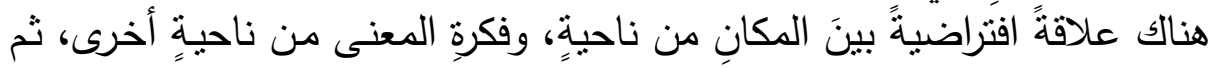




\section{المقدمة الطليلة في شعر المرقش الأكبر - دراسة تحليلية ونقدية}

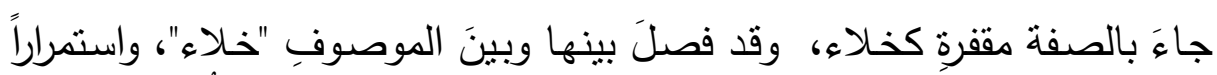

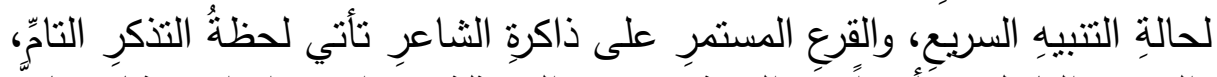

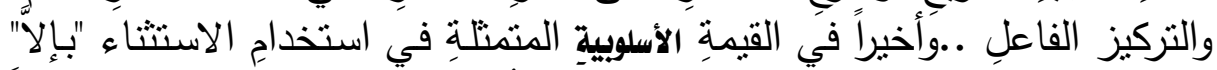

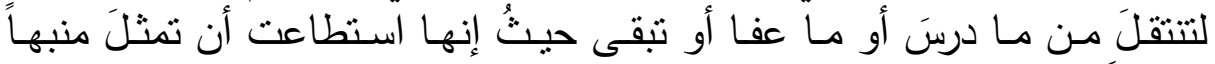

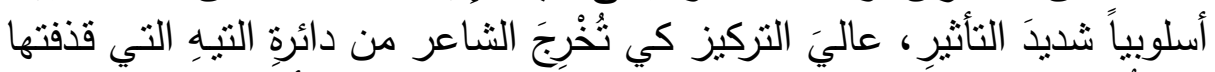

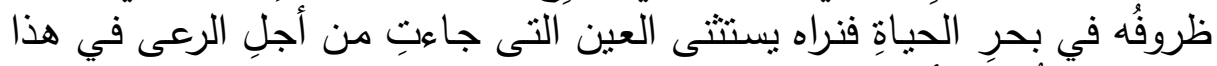

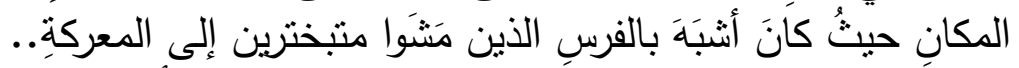

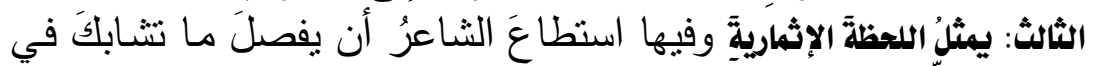

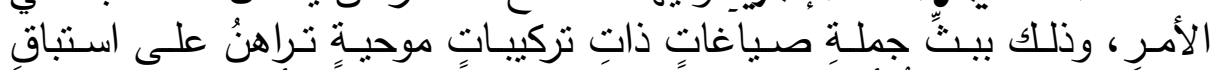

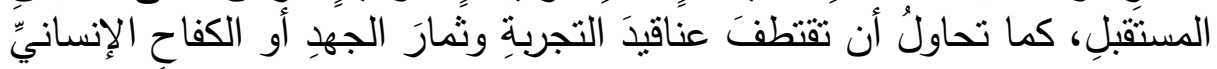

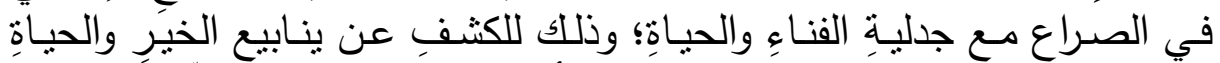

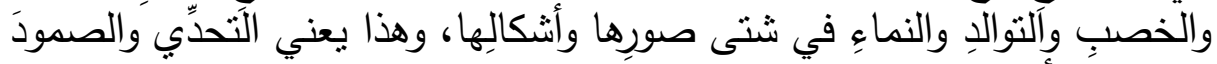

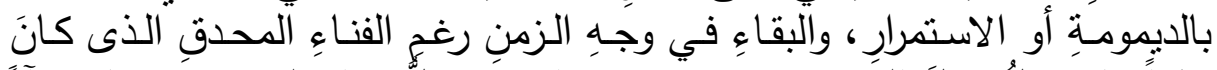

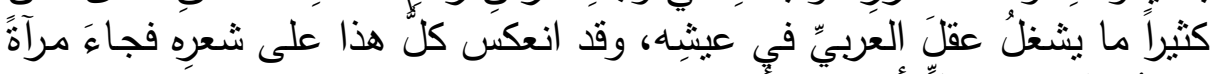

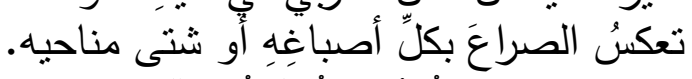

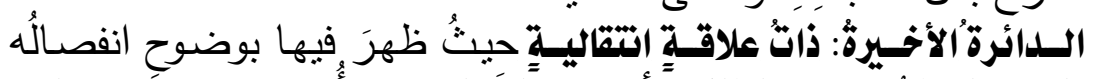

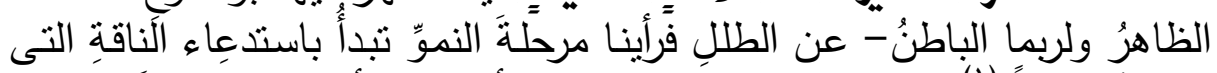

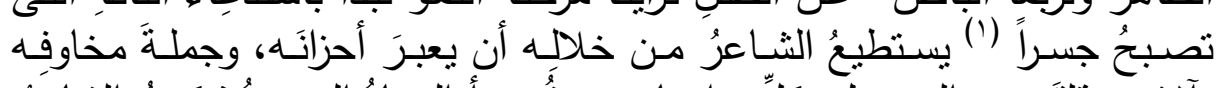

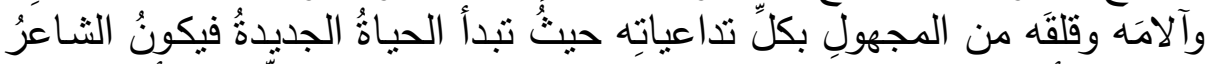

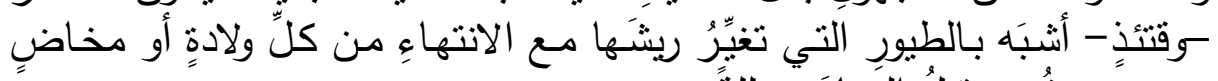

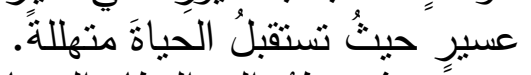

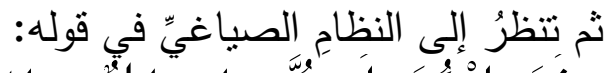

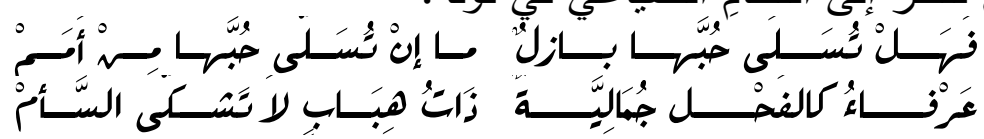

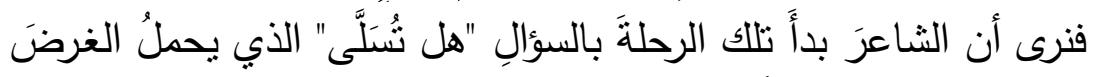

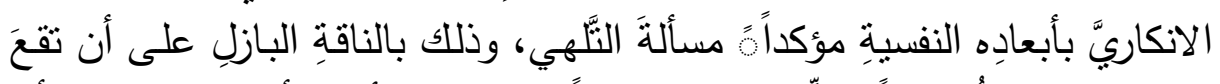

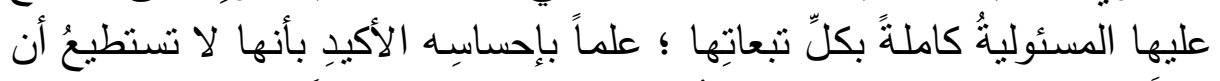
تملاًَ فراغَ حبييتِهِ التي كانت تمنتُ الدنيا بأسرِها سعادةً وأمناً.

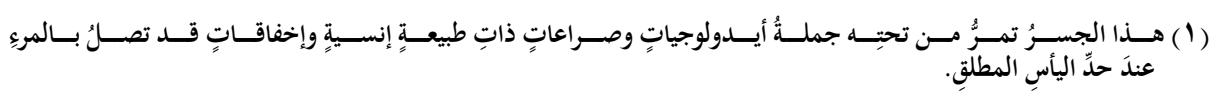




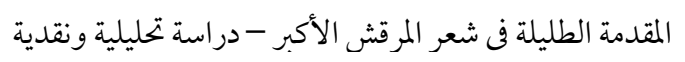

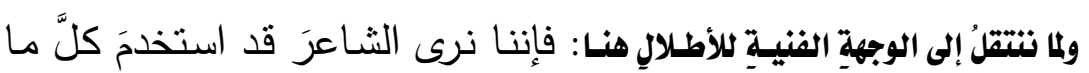

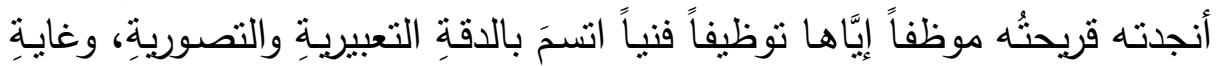

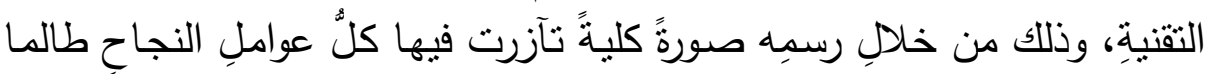

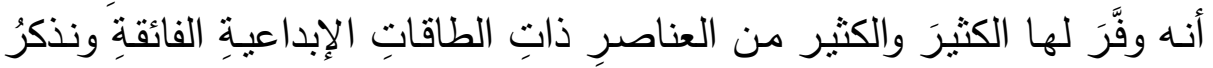
منها:

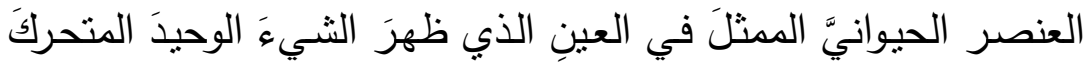

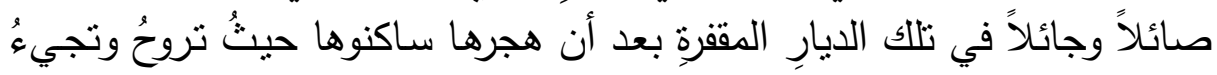

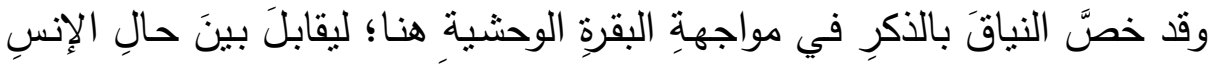

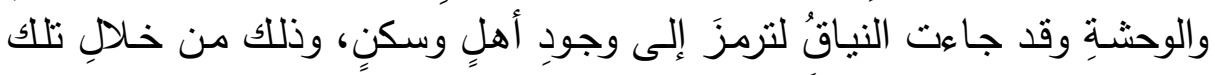

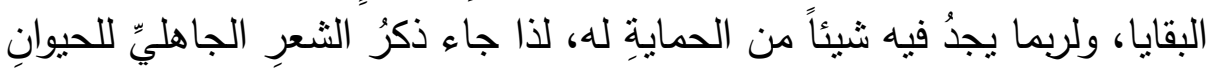

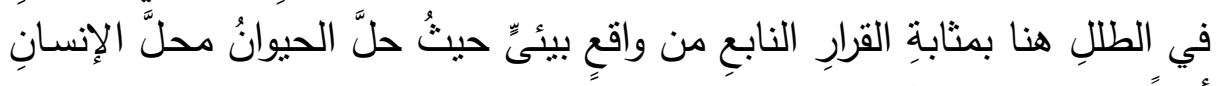

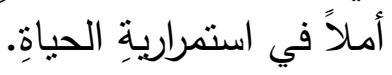

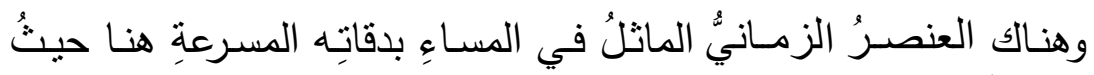

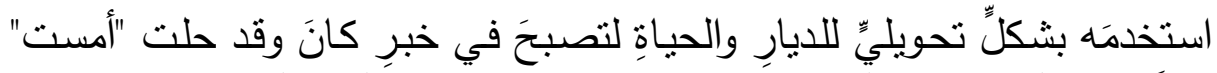

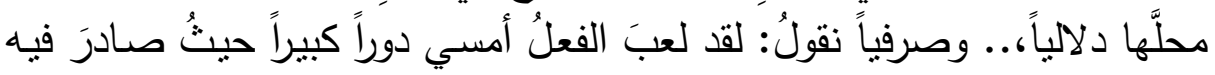

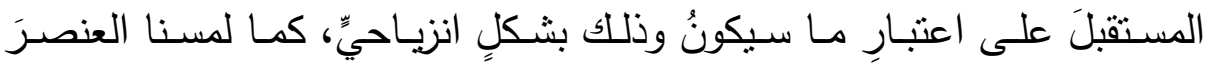

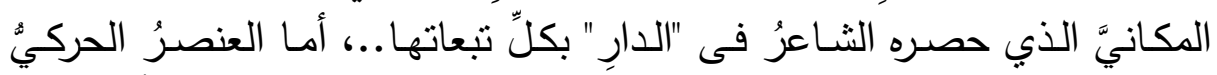

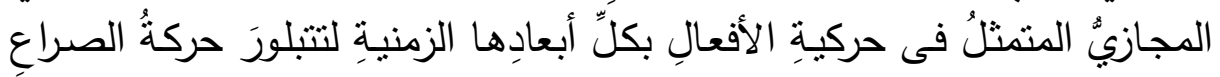

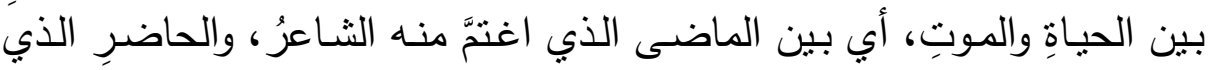

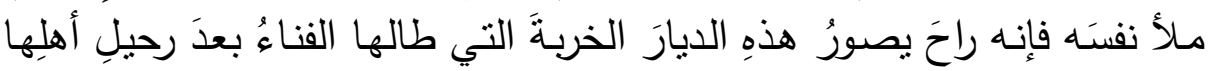

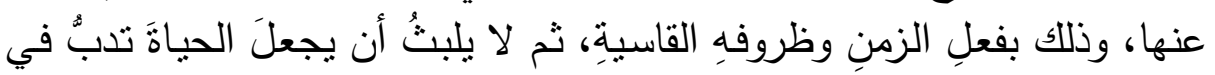
الديار من جديدٍ. 


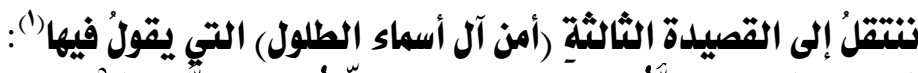

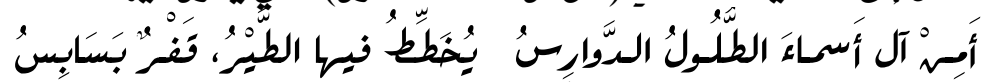

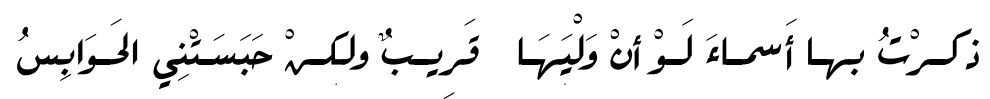

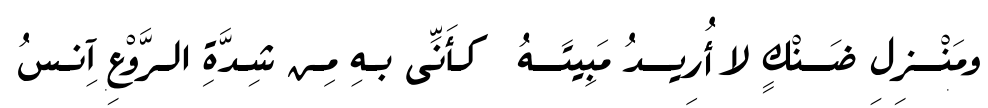

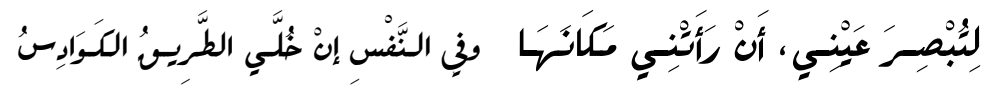

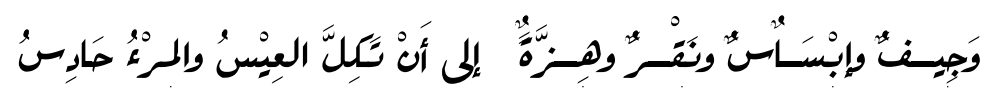

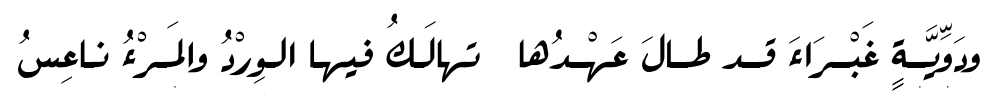

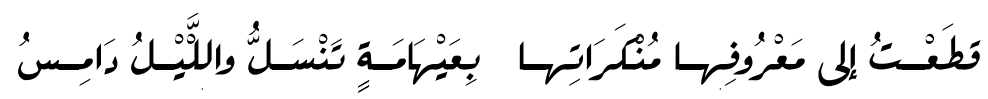

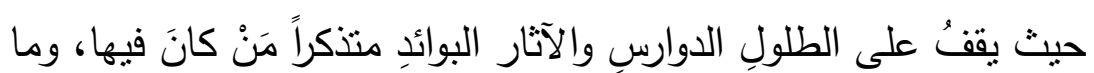

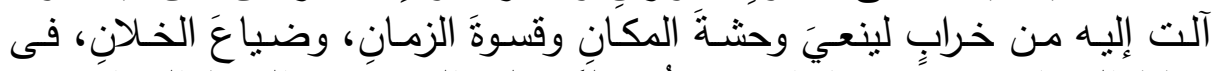

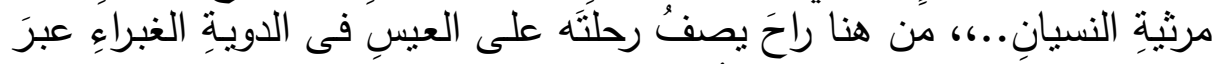

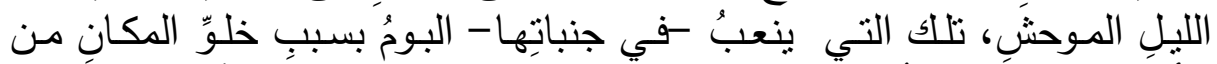

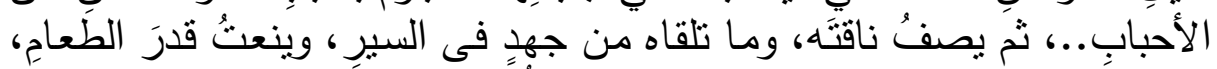

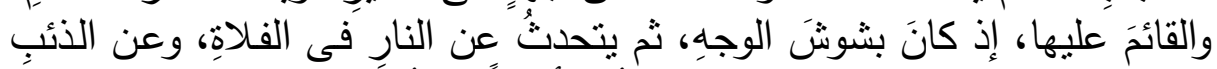

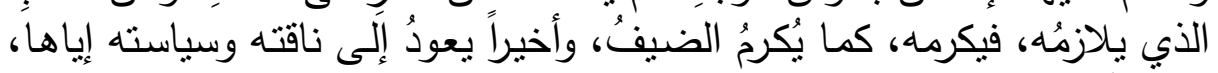

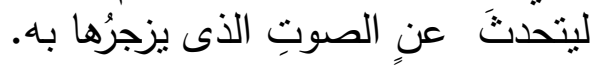

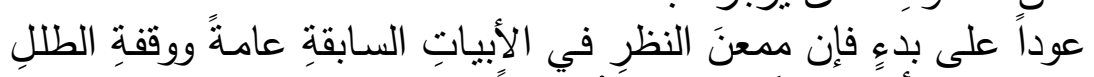

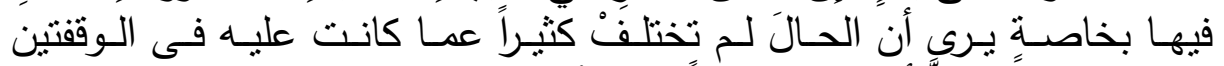

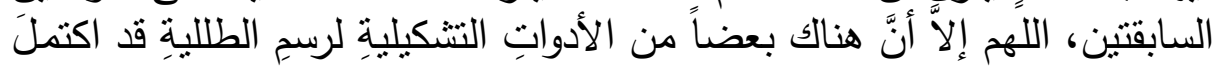




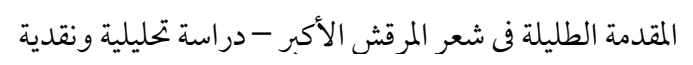

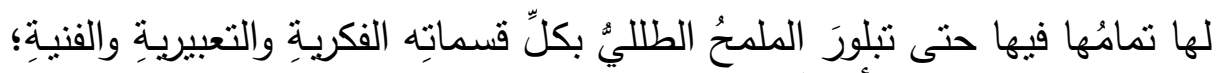

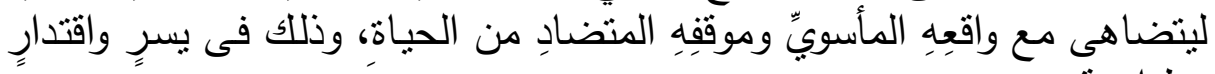
وطواعيةٍ.

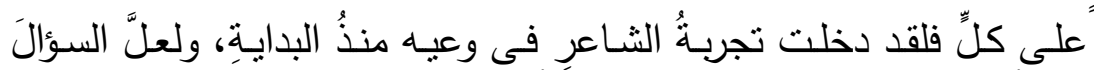

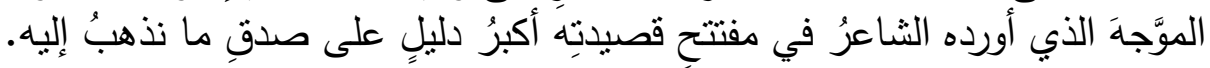

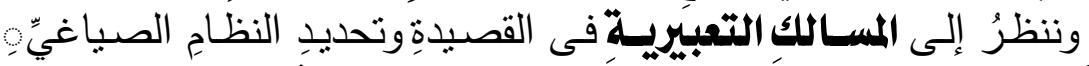

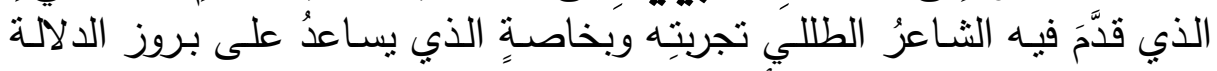

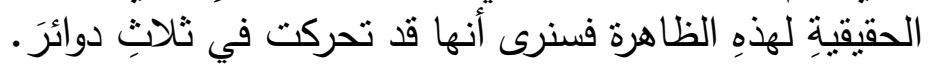

\section{الأولى: الحسية المباشرة ويمثلها البيثُ الأولُ القائلُ:}

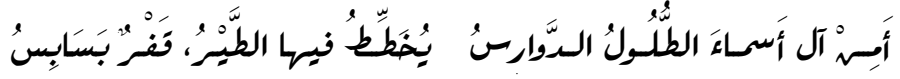

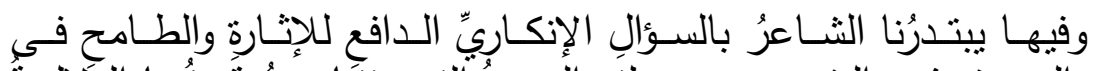

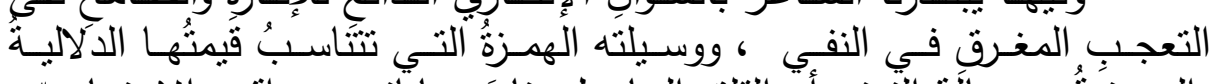

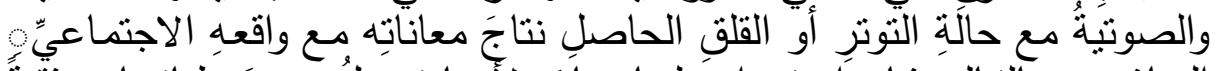

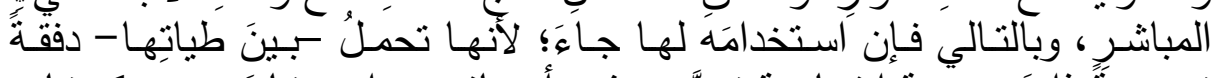

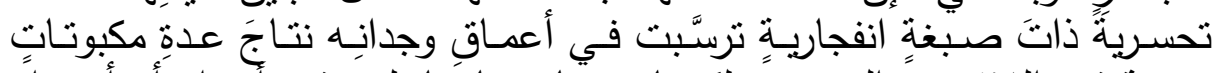

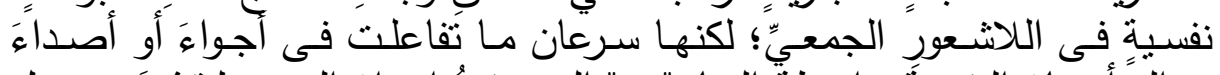

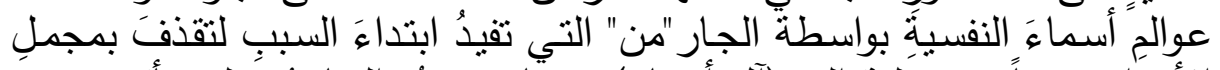

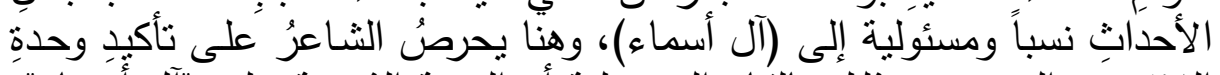

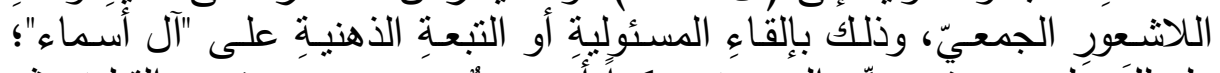

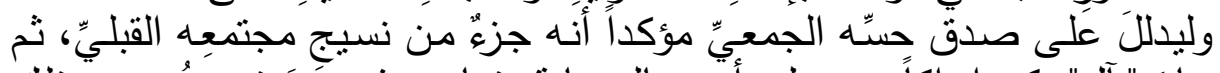

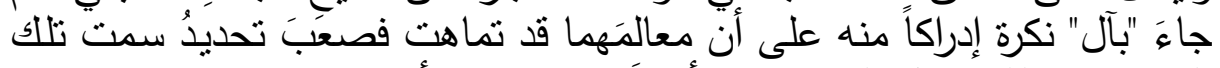

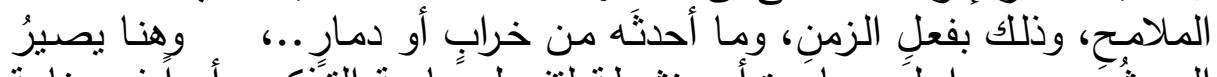

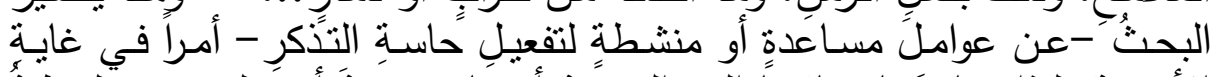

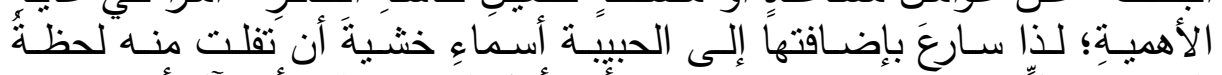

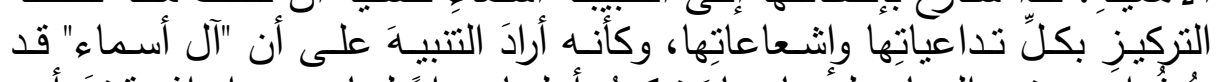

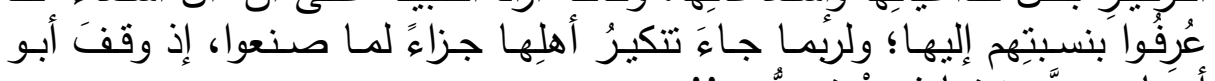

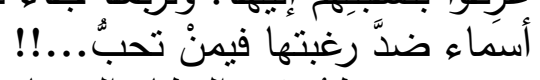

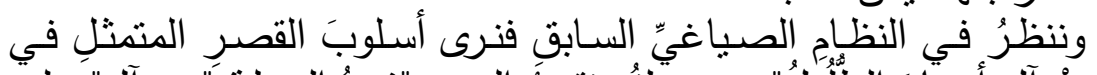

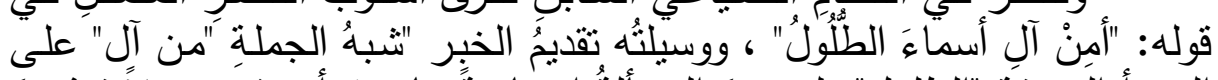

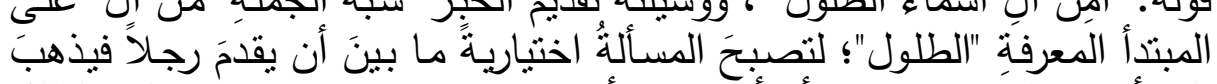

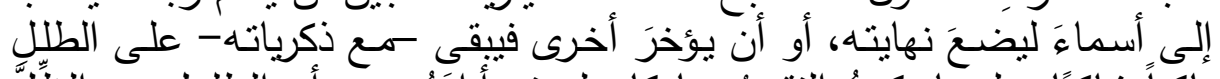

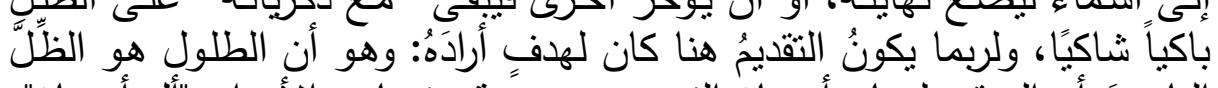

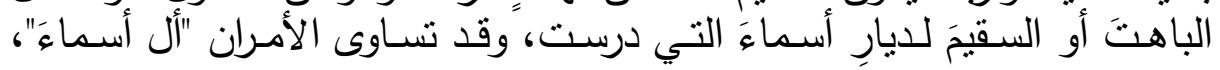




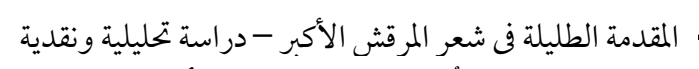

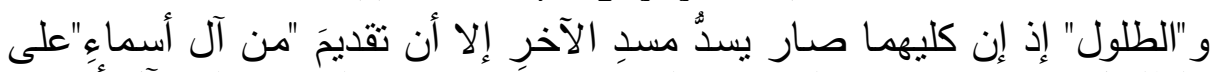

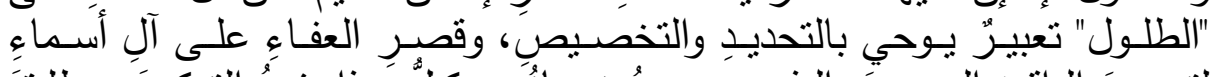

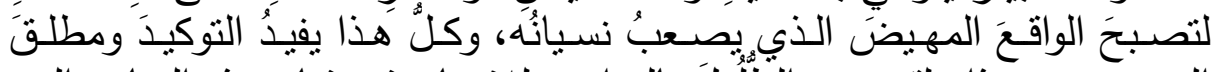

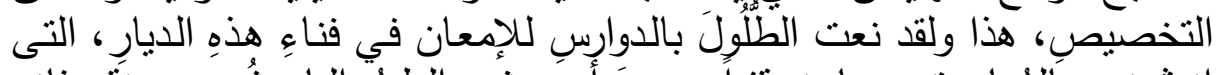

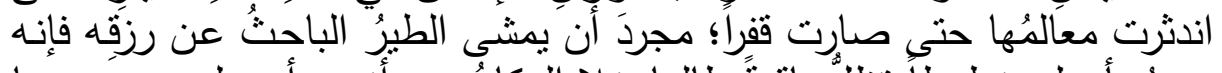

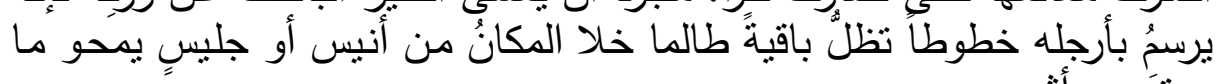

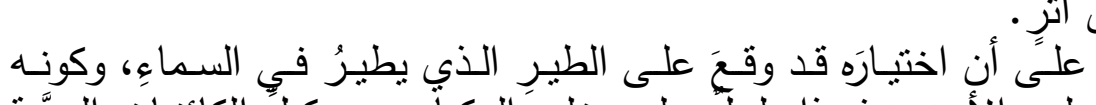

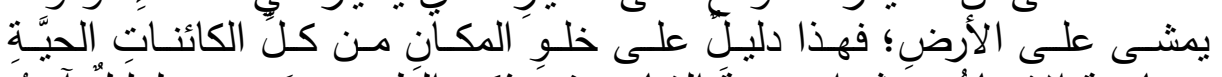

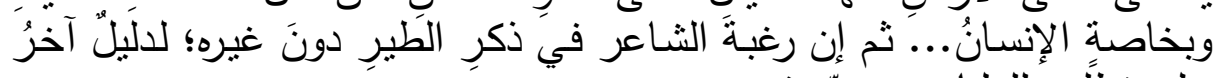

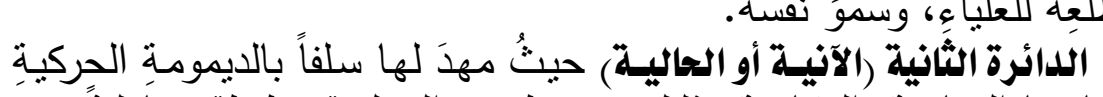

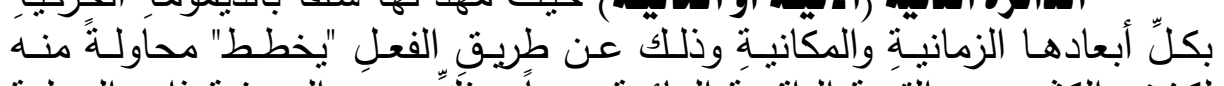

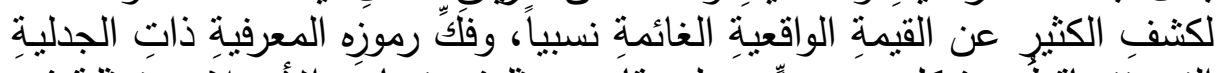

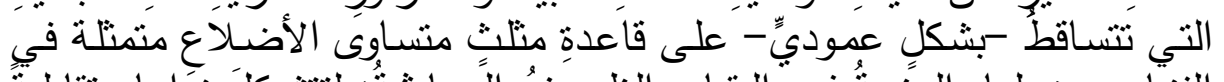

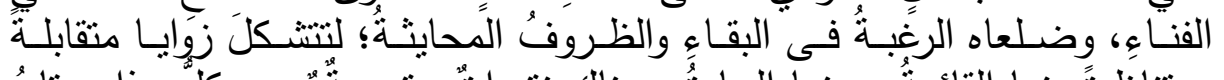

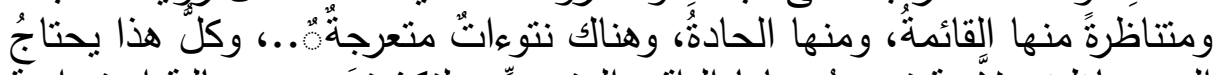

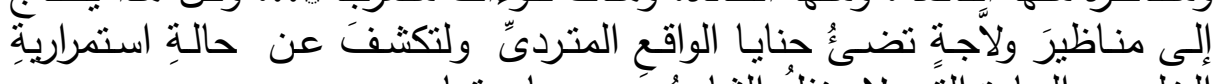

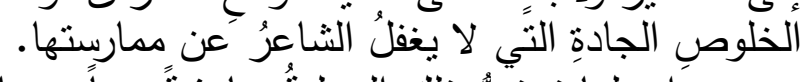

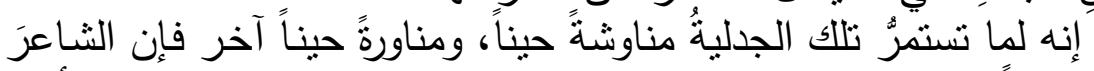

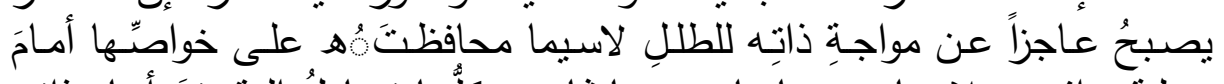

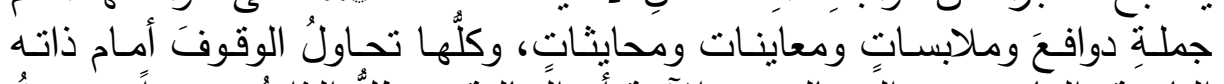

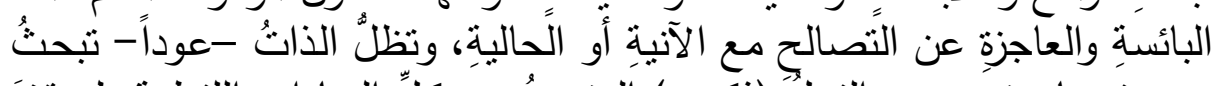

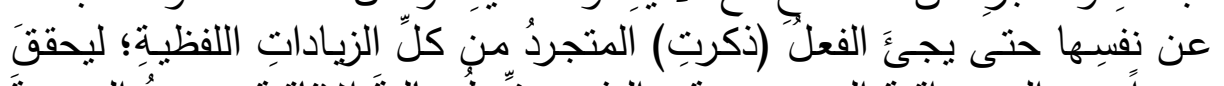

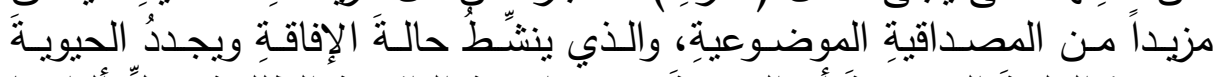

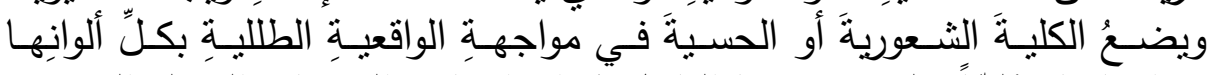

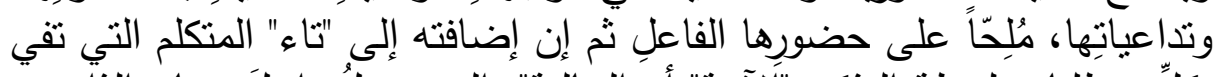

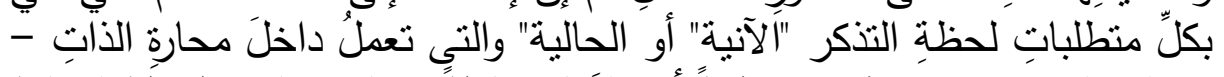

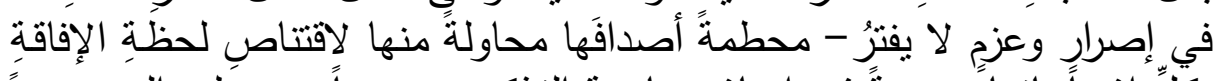

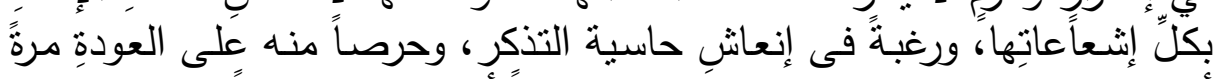
ناً طالى العرد

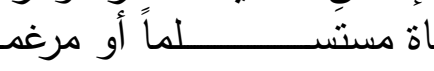

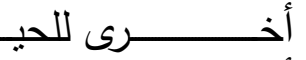
أنه قد فهَ دروسَها.

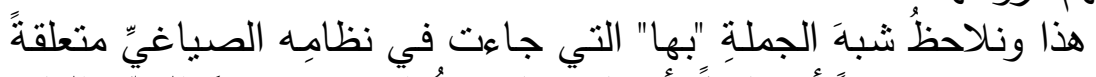

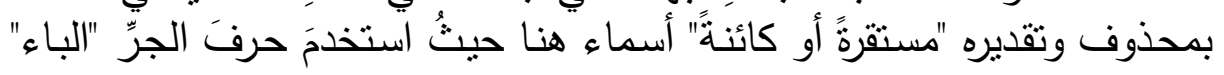




\section{المقدمة الطليلة في شعر المرقش الأكبر - دراسة تحليلية ونقدية}

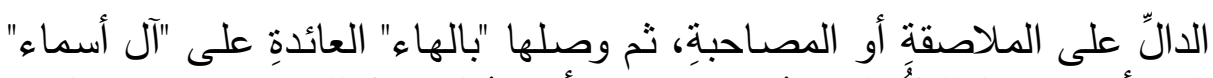

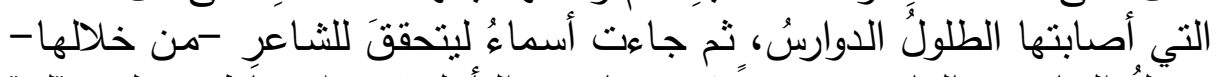

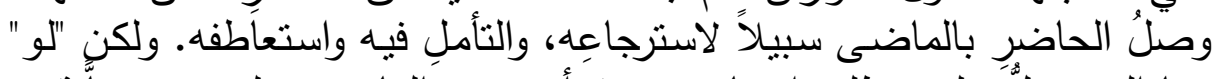

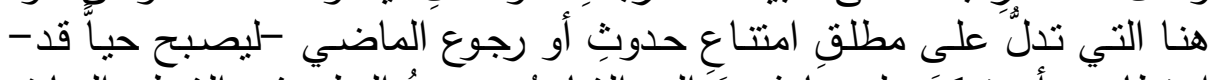

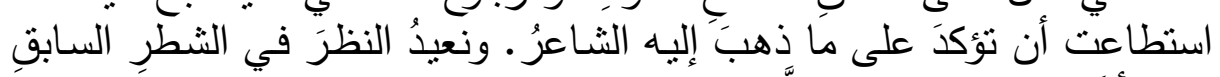

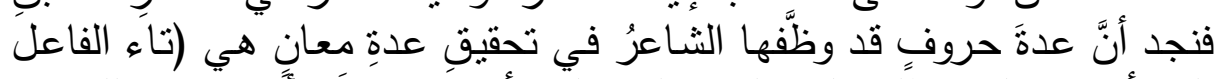

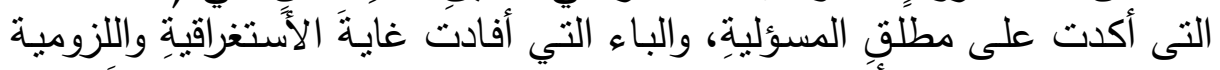

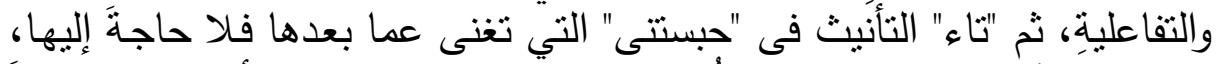

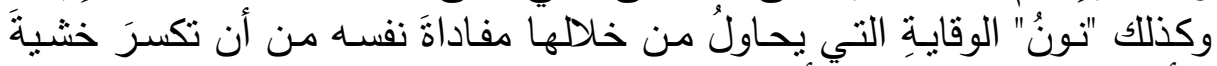

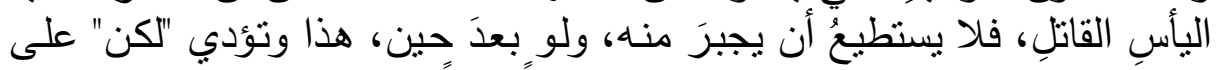

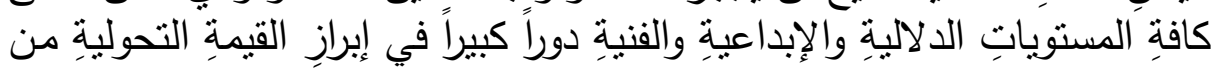

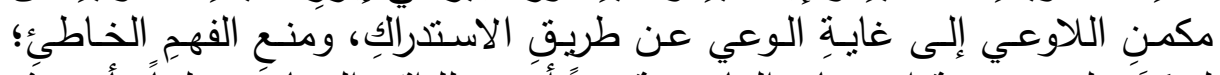

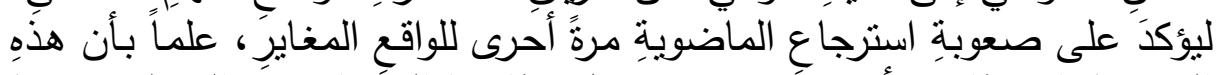

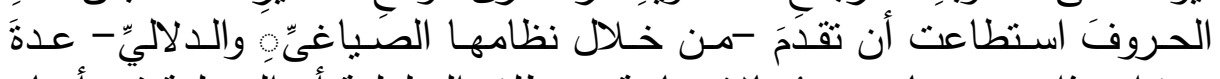

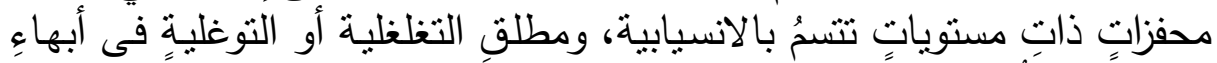

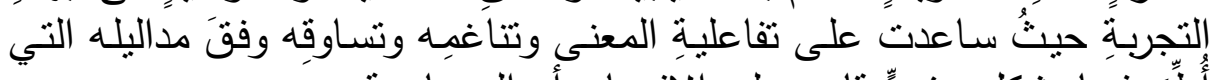

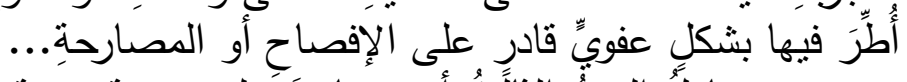

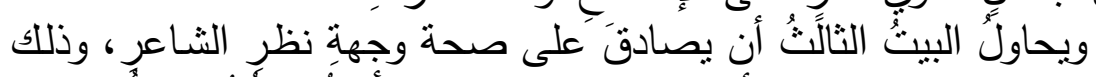

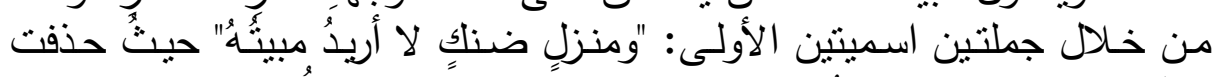

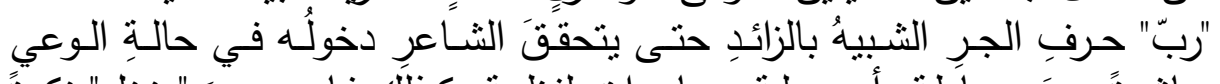

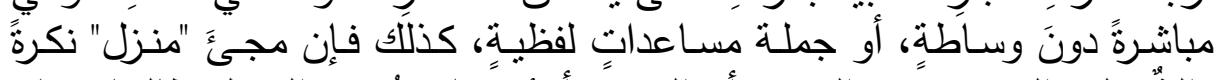

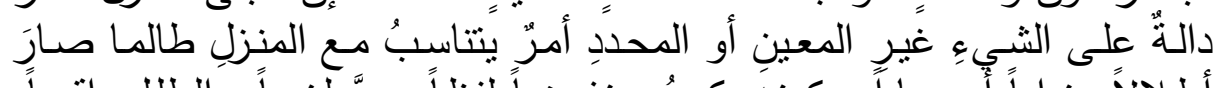

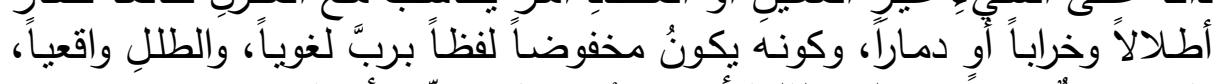

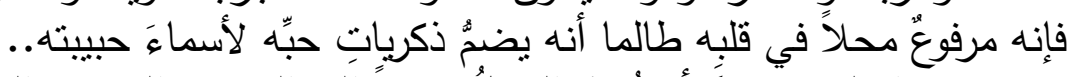

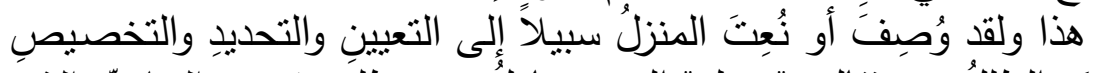

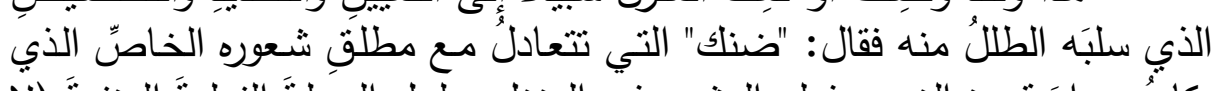

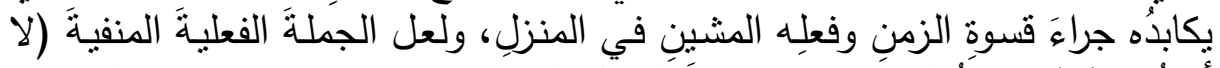

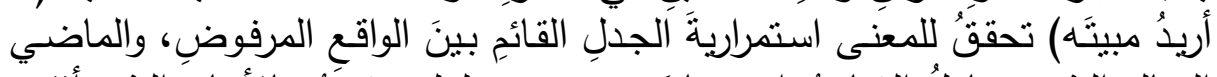

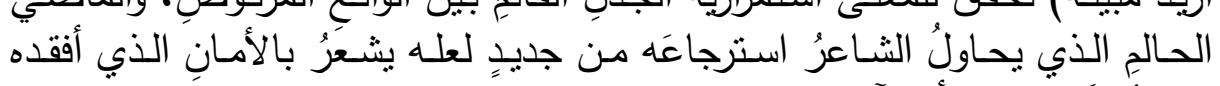

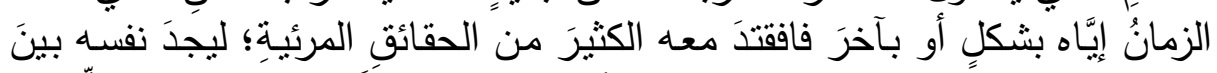

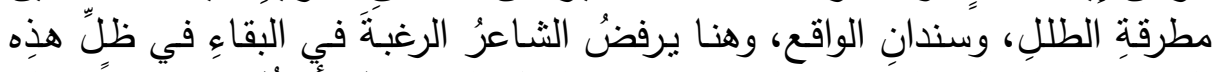

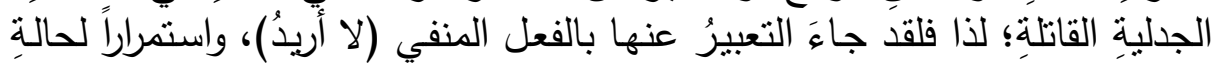




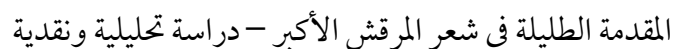

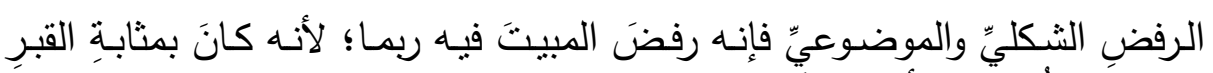

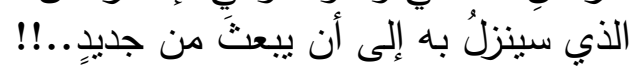

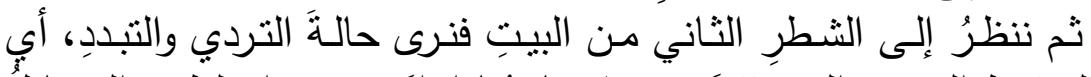

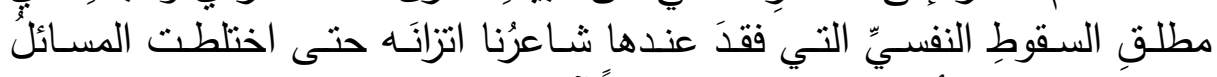

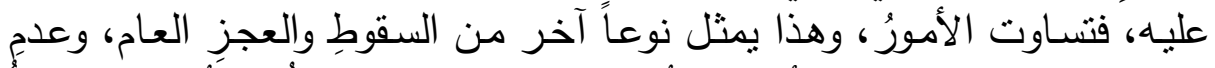

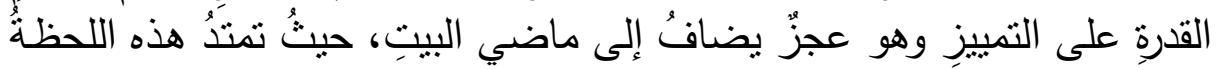

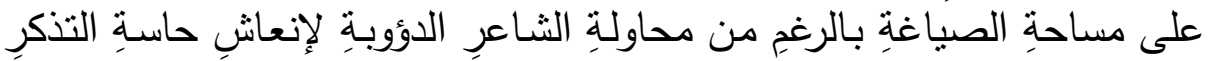

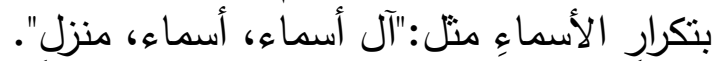

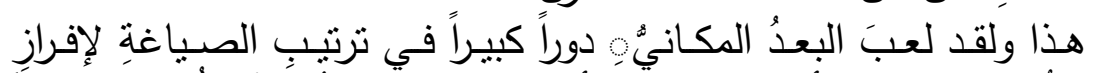

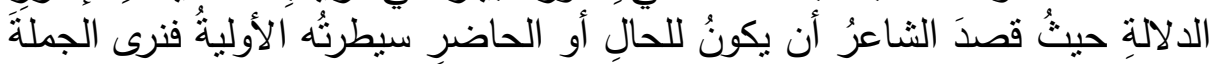

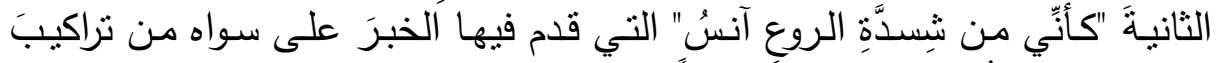

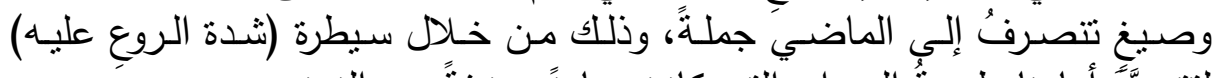

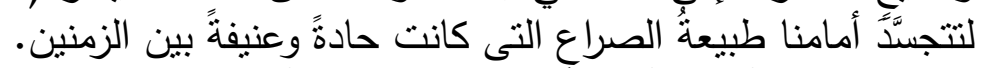

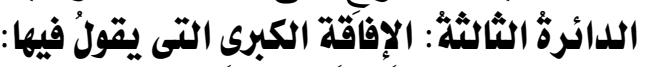

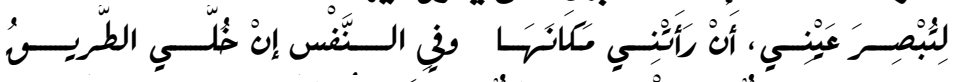

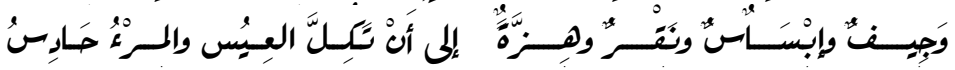

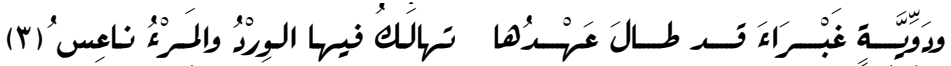

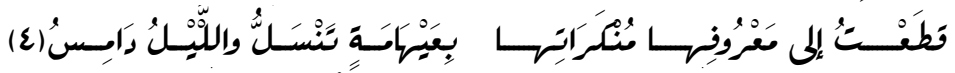

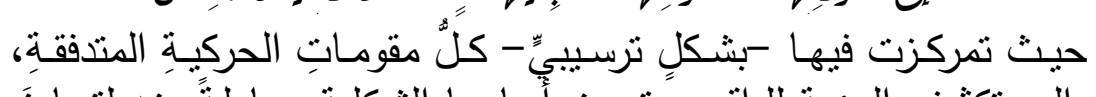

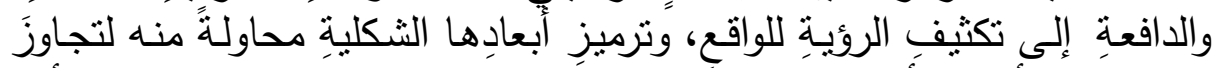

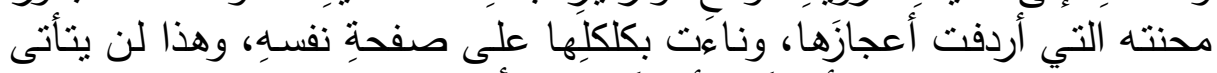

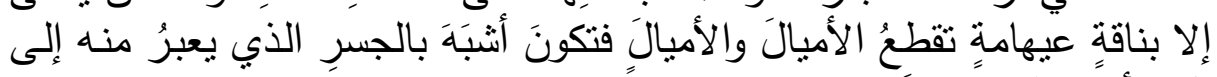

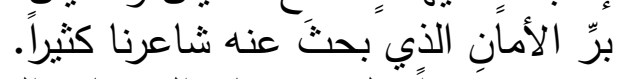

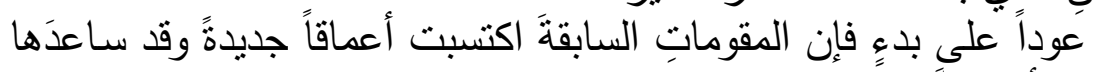

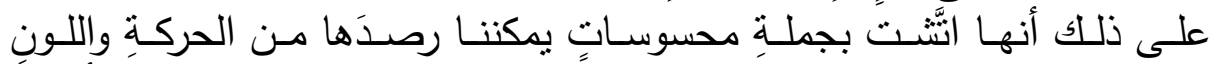

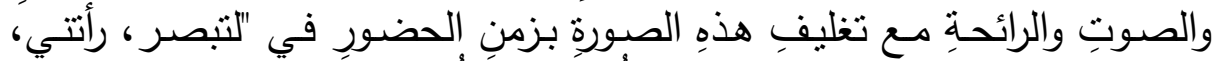

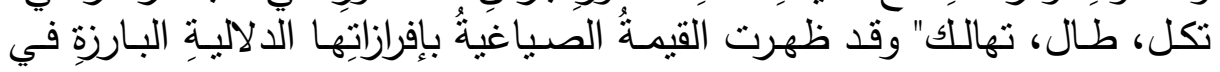




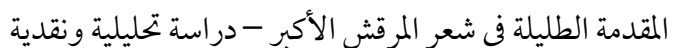

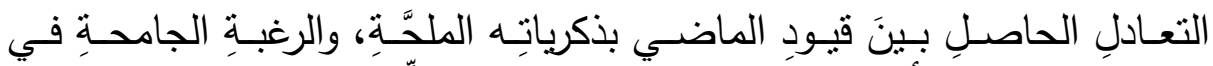

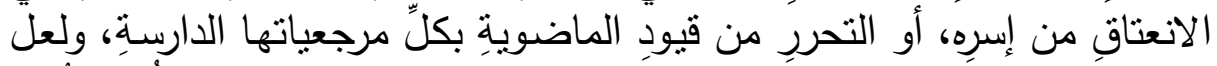

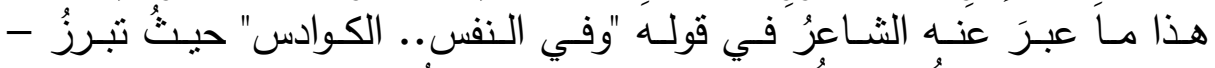

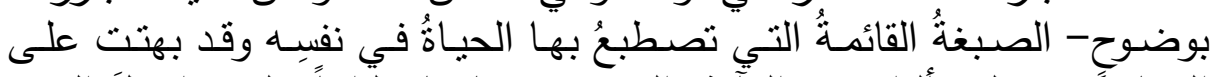

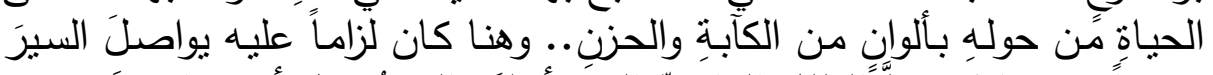

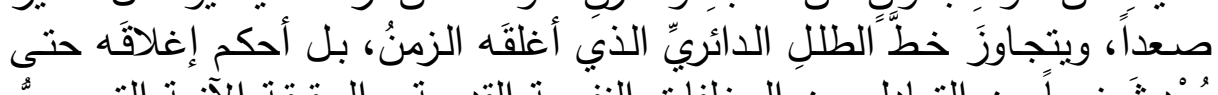

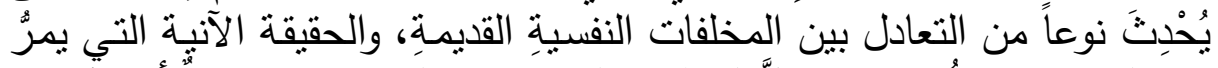

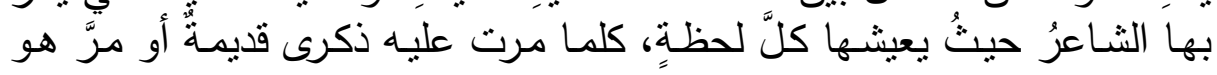
على هذهِ الذكرى.

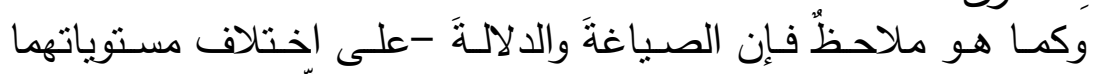

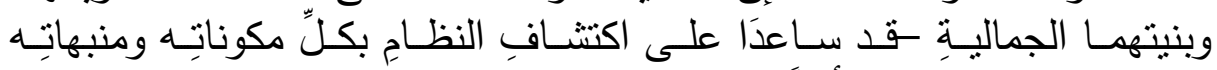

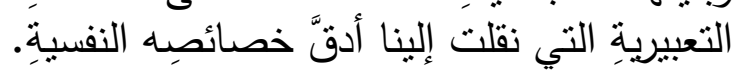

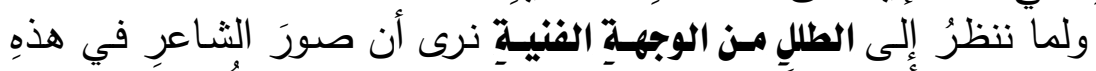

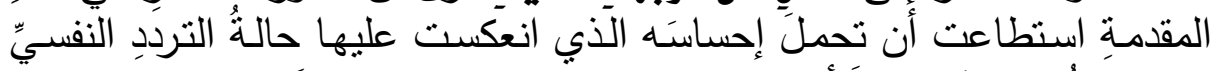

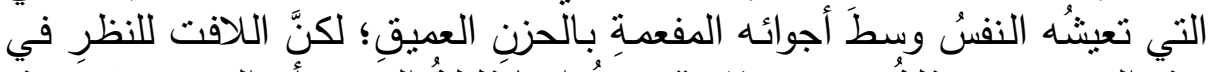

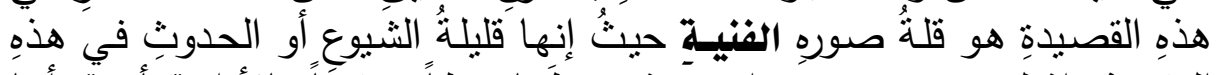

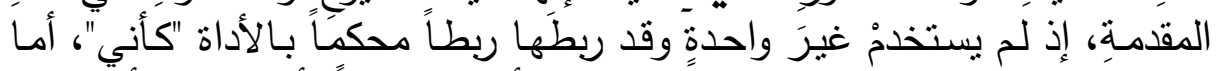

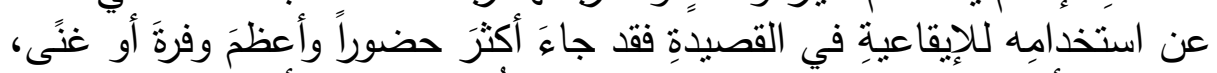

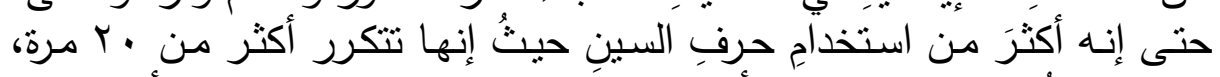

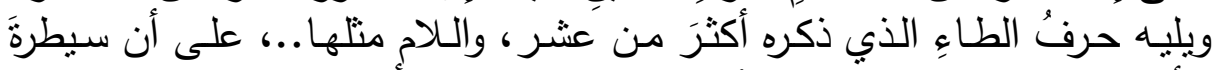

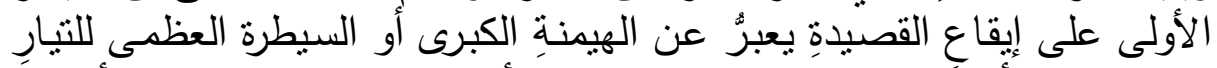

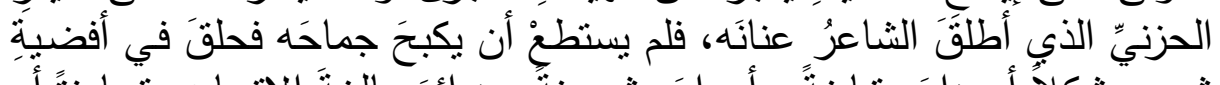

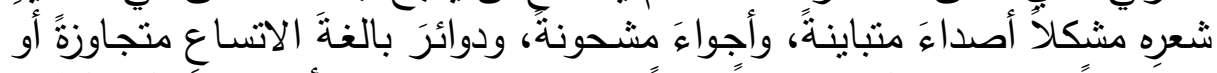

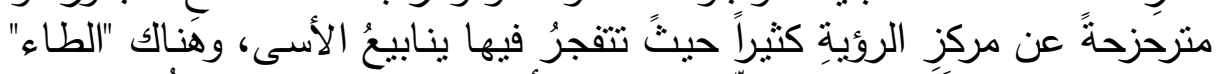

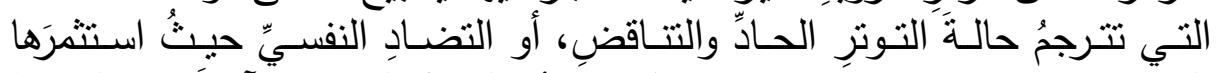

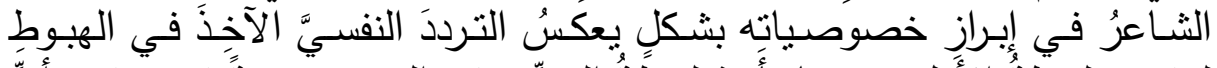

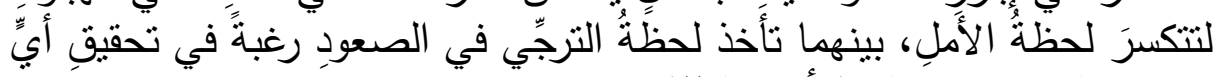

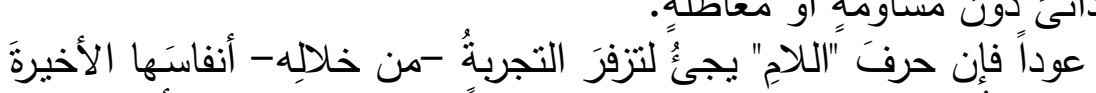

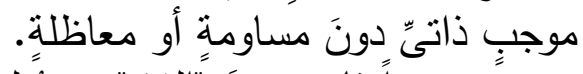

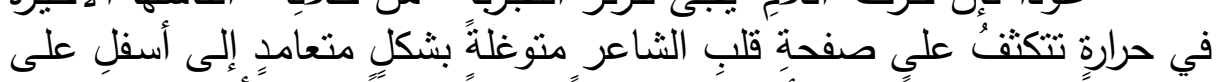

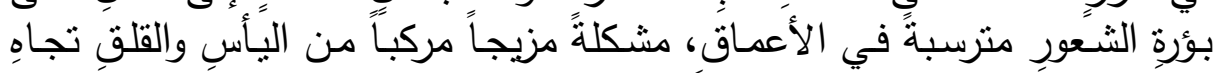

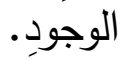




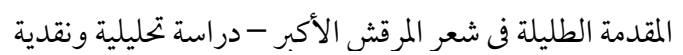

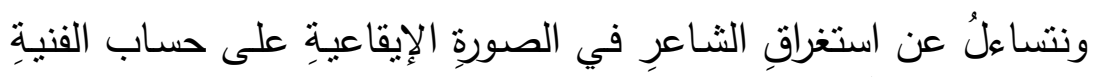

فلربما يكون هذا راجُع لسبينين:

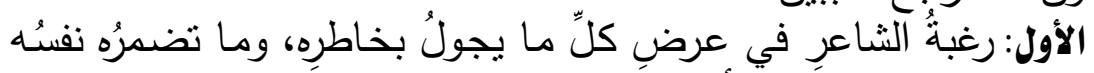

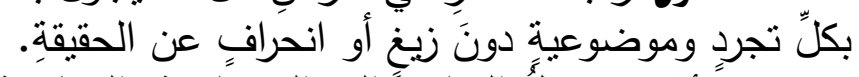

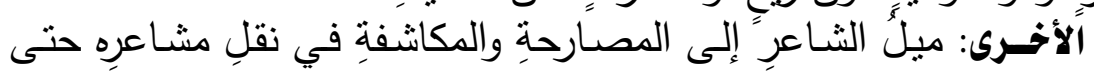

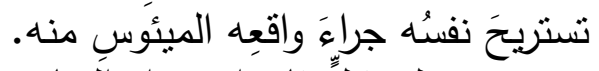

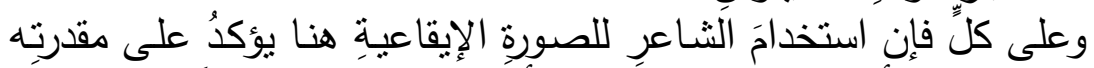

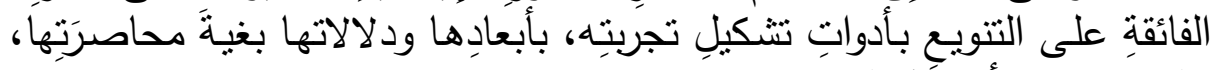

\section{运}

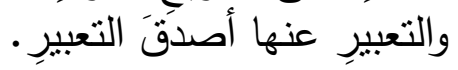

المبحث الثاني : لوحة الطللُ و أنماط قصائدها البنائبة لدى الثـاعر

در اسة وتحليل "

حيث جاء موزعاً على محورين : الموزئ :

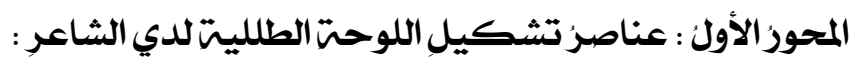

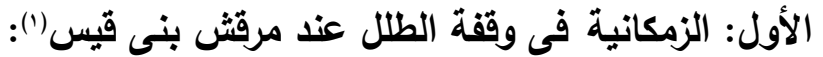

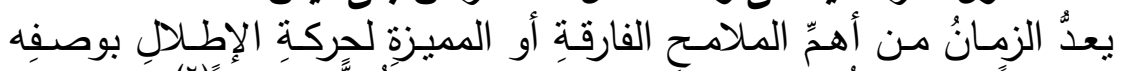

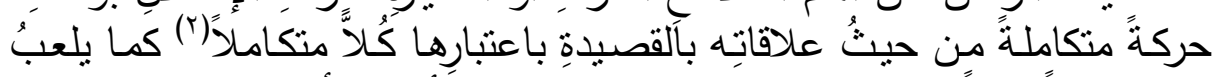

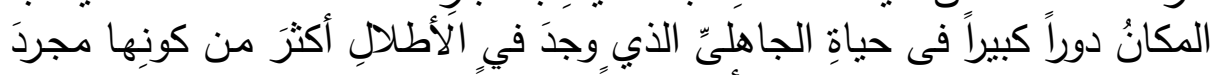

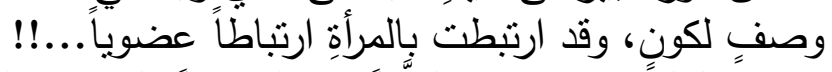

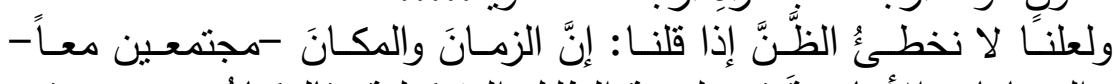

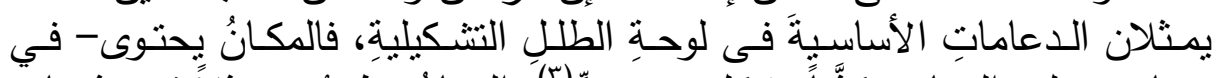

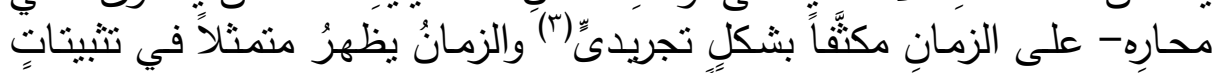

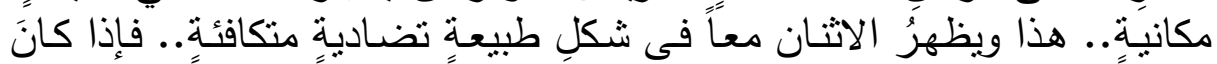

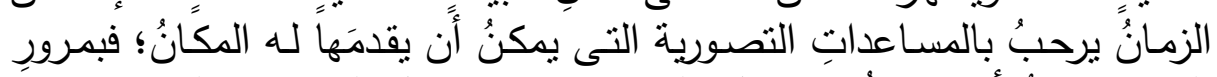

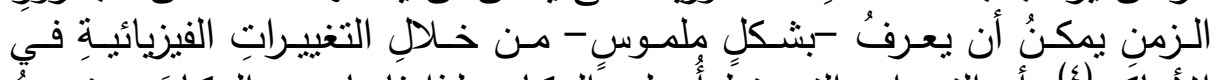

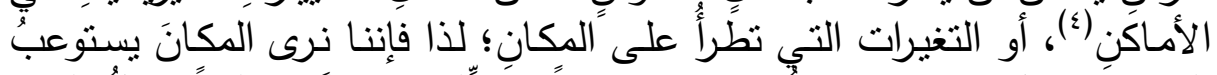

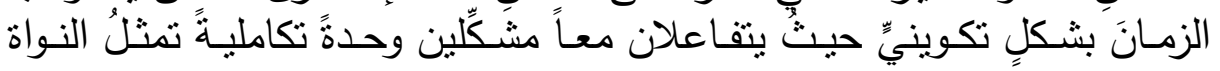

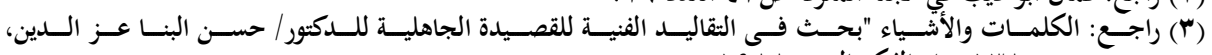




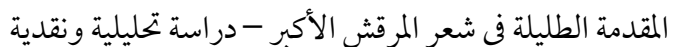

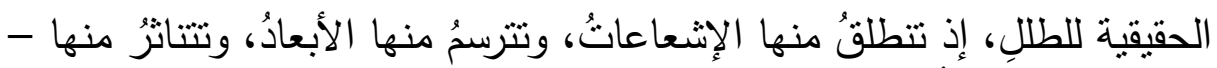

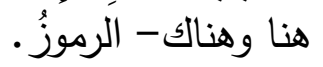

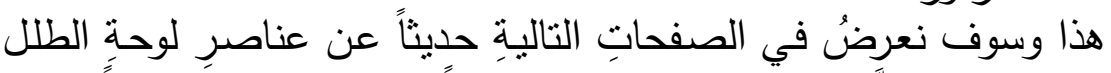

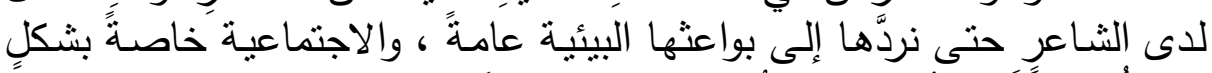

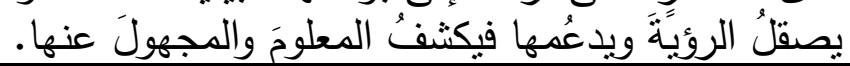

\begin{tabular}{|c|c|c|}
\hline الزمكانية في طلل الاكبر & بناؤها & القصيلة \\
\hline 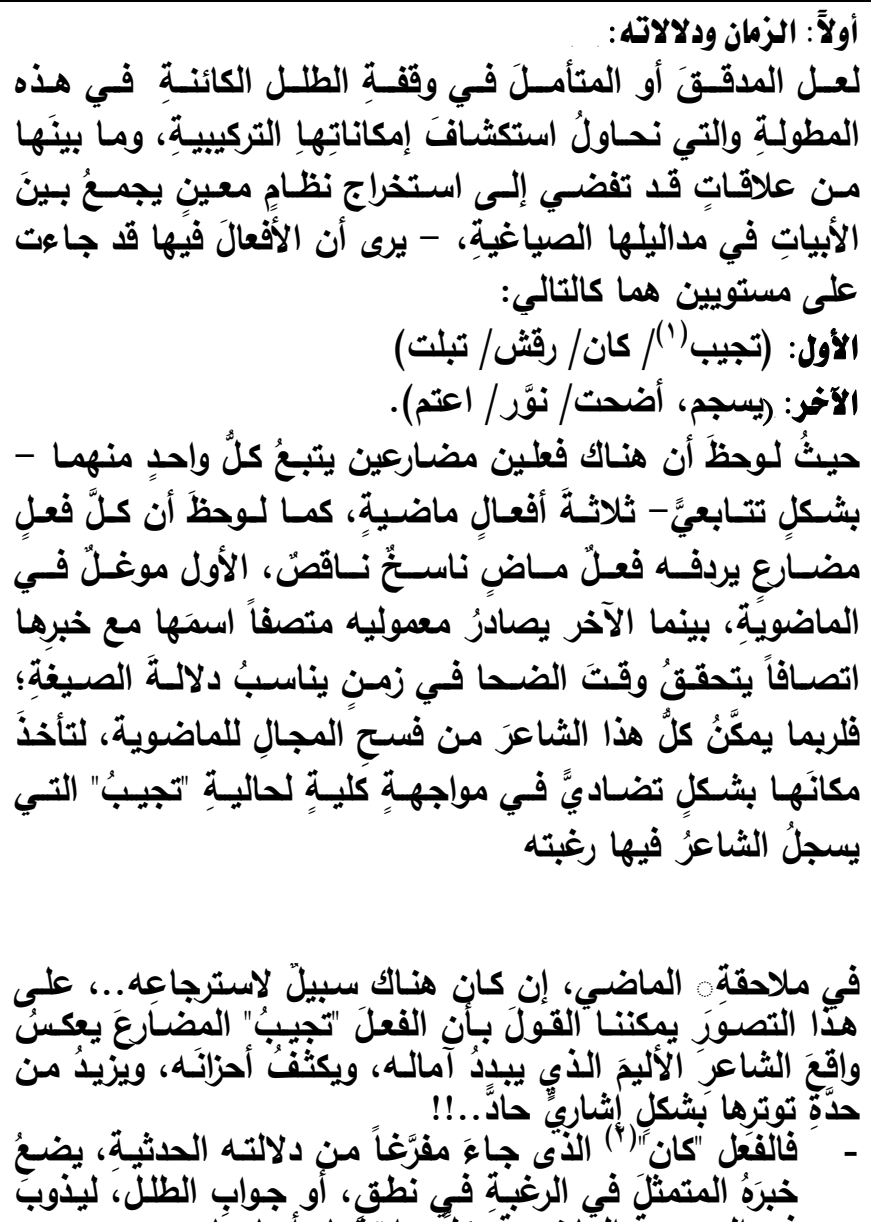 & 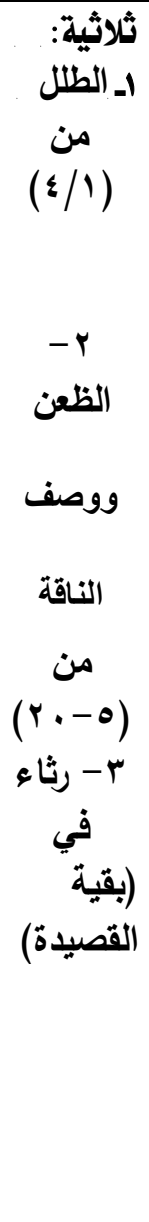 & هل هد أبياتهيّار \\
\hline
\end{tabular}


ב= المجلد الأول من العدد الخامس والعثرين لحولية كلية الدراسات الإسلامية والعربية للبنات ـ بالإسكندرية ع المقدمة الطليلة في شعر المرقش الأكبر - دراسة تحليلية ونقدية

\begin{tabular}{|c|c|c|}
\hline الزمكانية في طلل الاككبر & الموضاؤها & القصيلة \\
\hline - & & \\
\hline 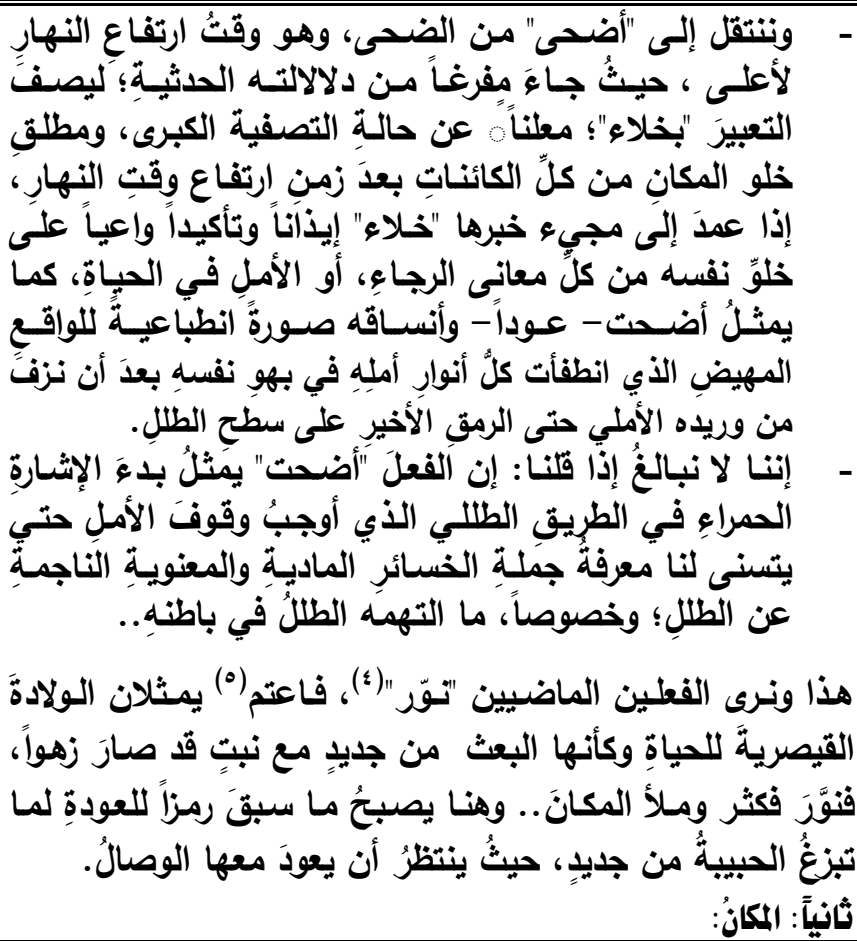 & & \\
\hline
\end{tabular}

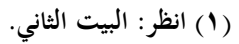


= المجلا الأول من العدد الخامس والعثرين لحولية كلية الاراسات الإسلامية والعربية للبنات ـ بالإسكندرية سل

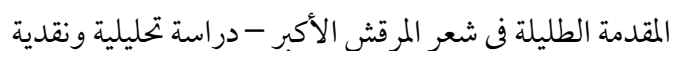

\begin{tabular}{|c|c|c|}
\hline الزمكانية في طلل الاكبر & الموضاؤها & القصيلة \\
\hline 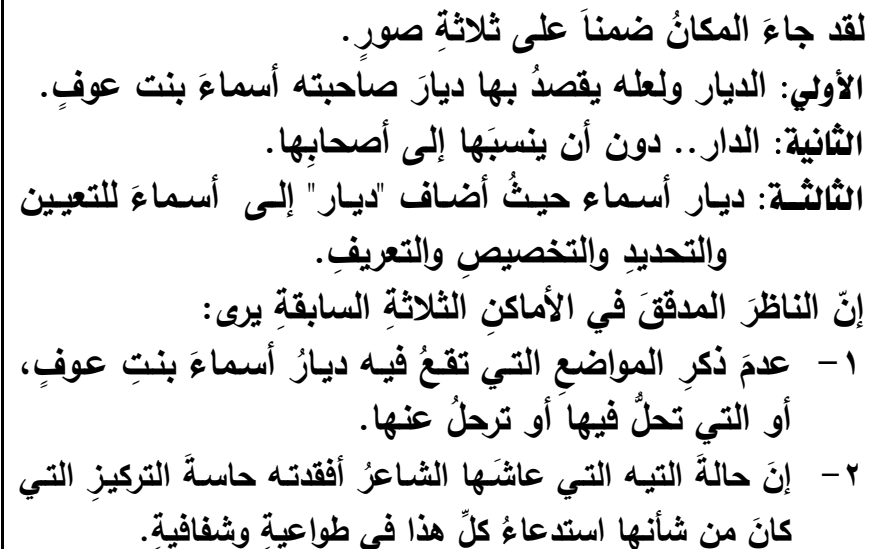 & & \\
\hline
\end{tabular}

القصيدة 


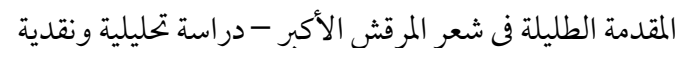

\begin{tabular}{|c|c|c|}
\hline 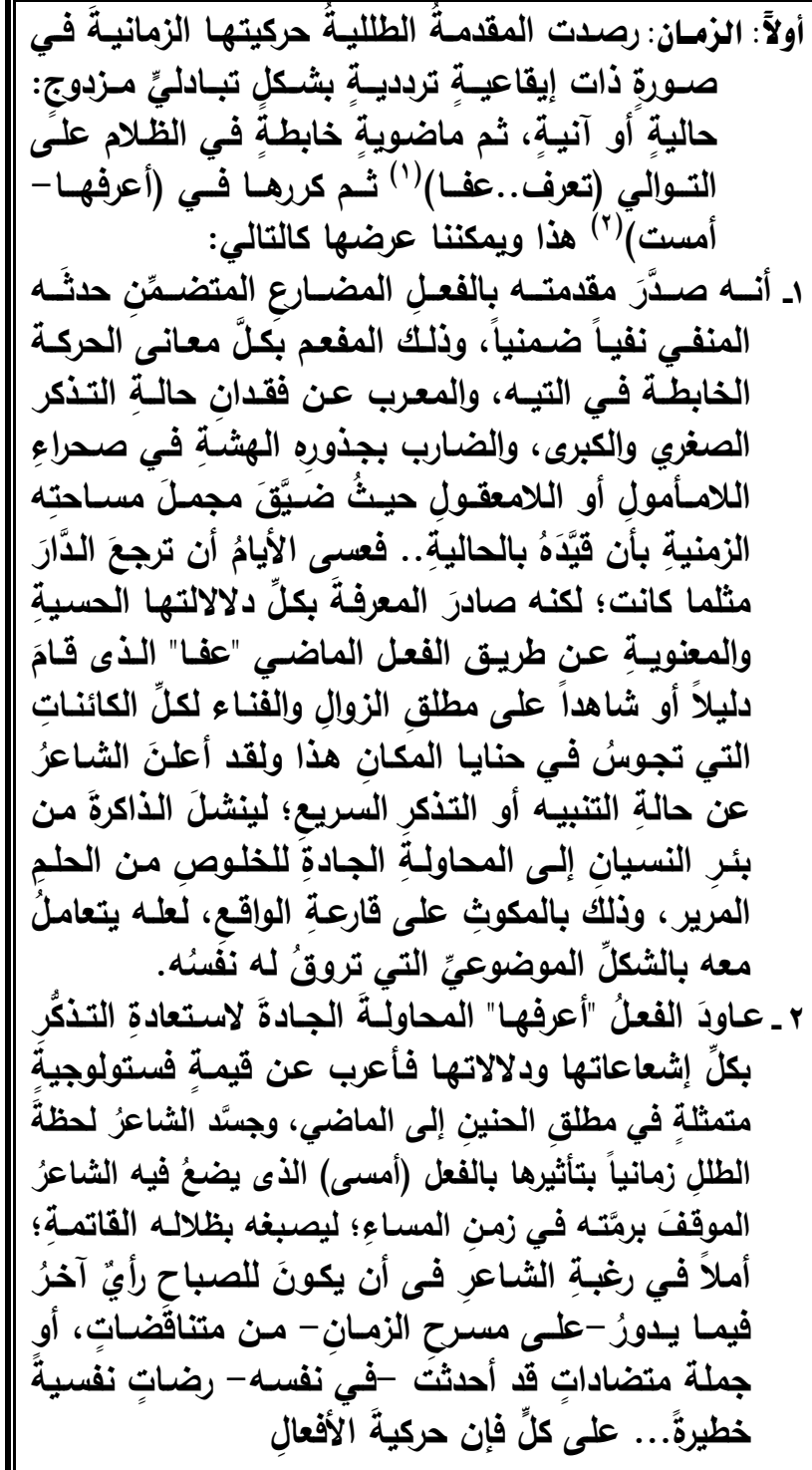 & 1 1 - ثنائية: & 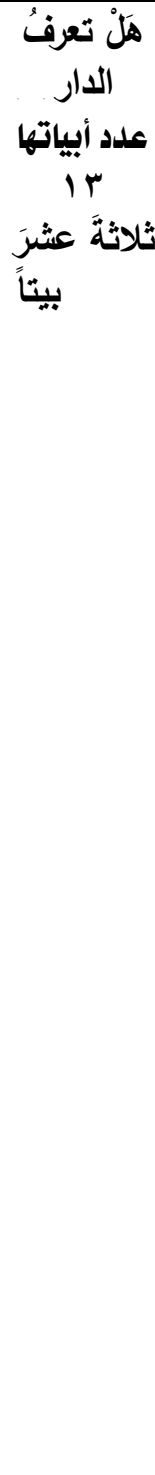 \\
\hline
\end{tabular}




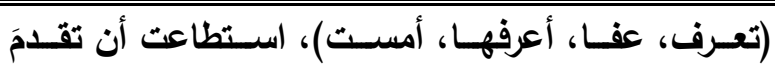

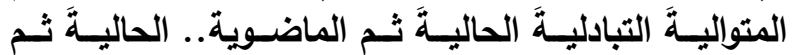

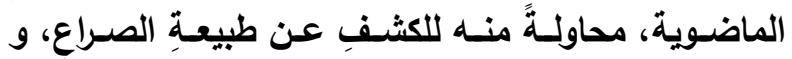

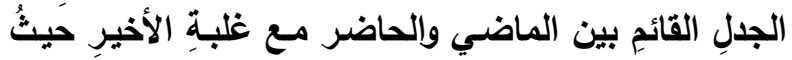

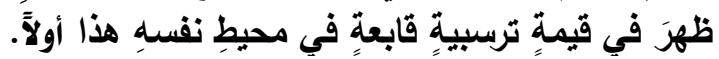

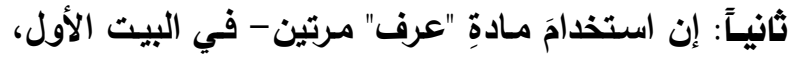

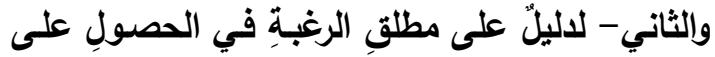

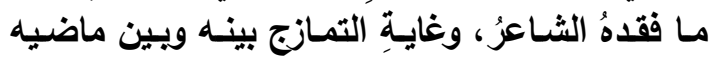

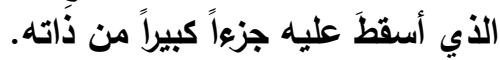

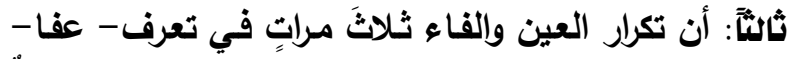

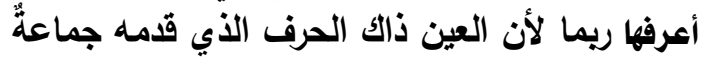

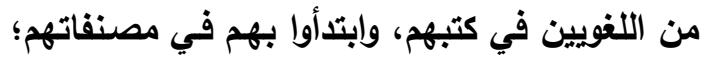

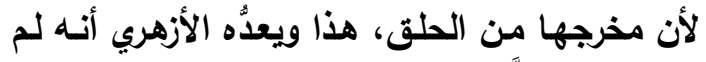

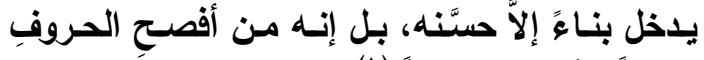

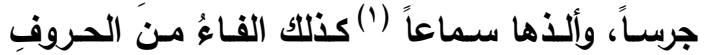

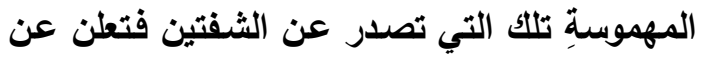

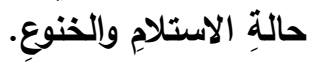
ثانياً المكان:

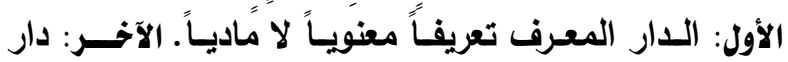

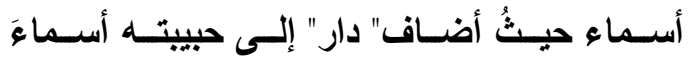
لتحديدها معنوياً. 
ב= المجلد الأول من العدد الخامس والعثرين لحولية كلية الدراسات الإسلامية والعربية للبنات ـ بالإسكندرية ع

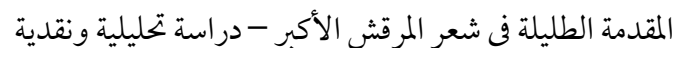

\begin{tabular}{|c|c|c|}
\hline الزمان والمكان ودلالاتهما & عدد أبياتها & القصيلة \\
\hline 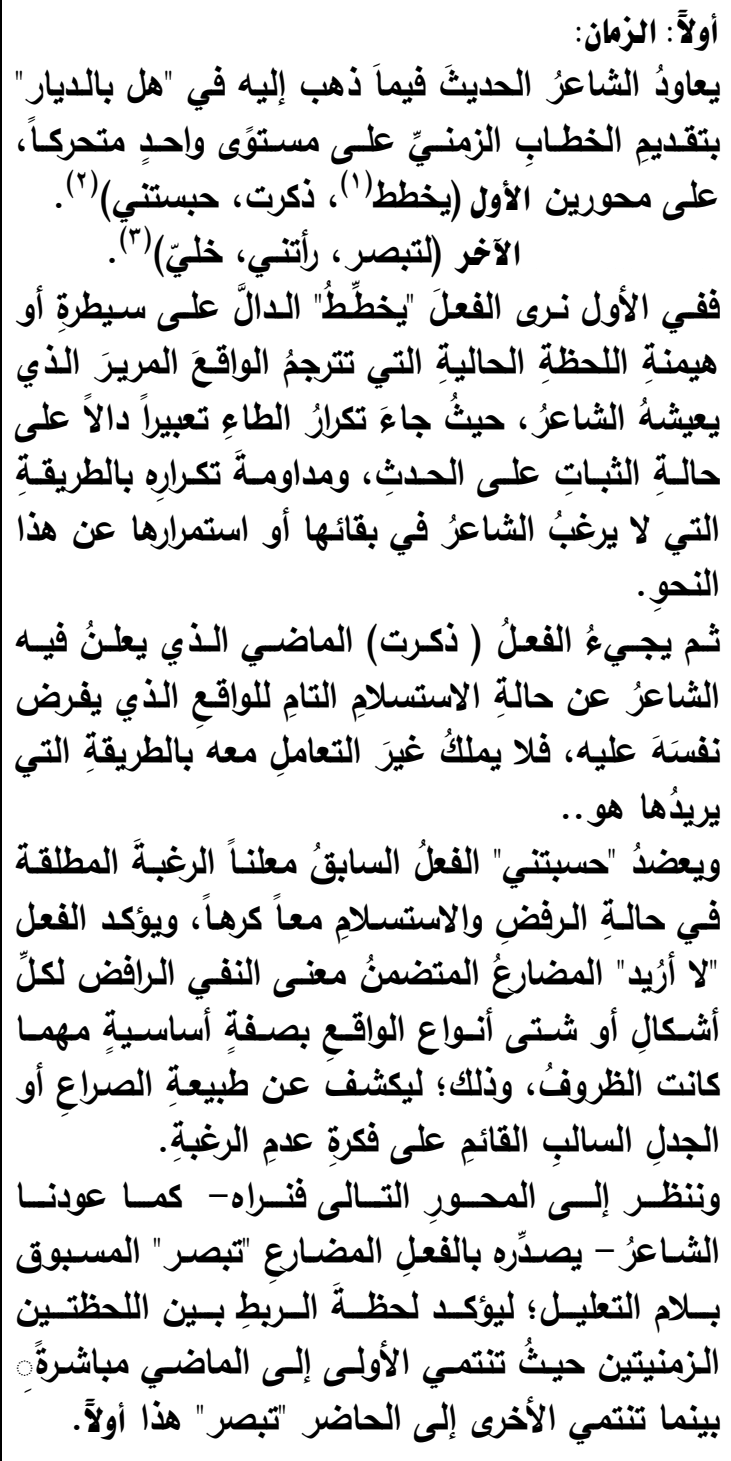 & 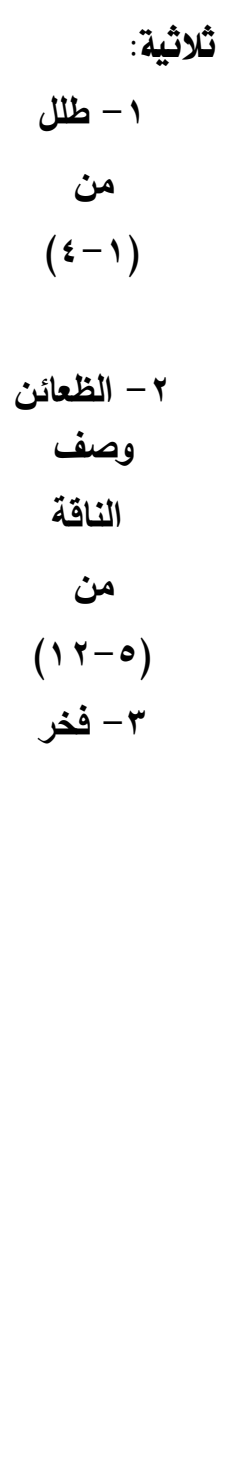 & عدد أبياتها \\
\hline
\end{tabular}

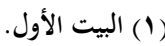




\begin{tabular}{|c|c|c|}
\hline الزمان والمكان ودلالاتهما & عدد أبياتها & القصيدة \\
\hline 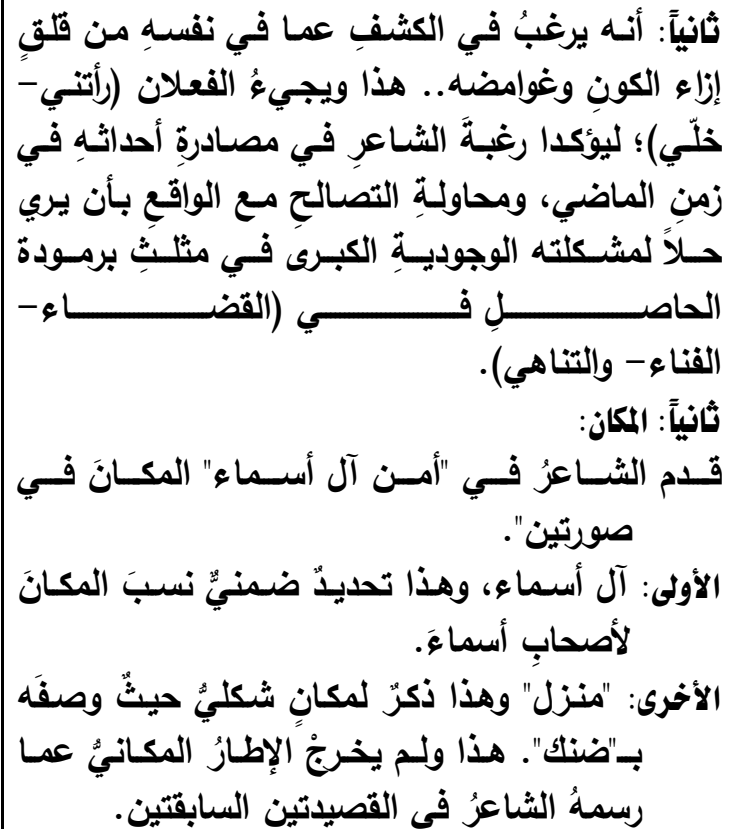 & & \\
\hline
\end{tabular}

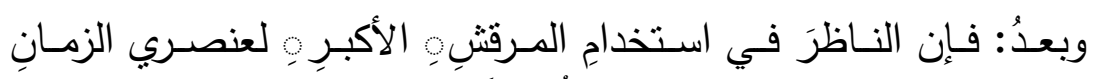

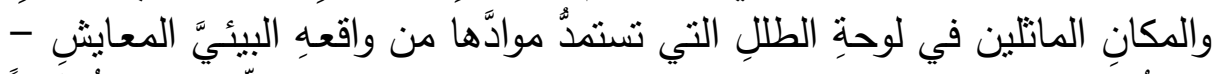

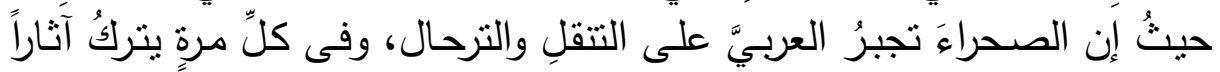

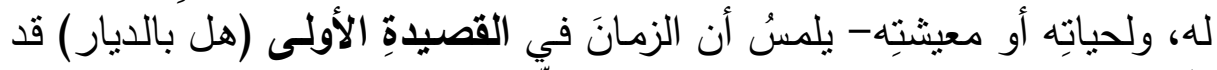

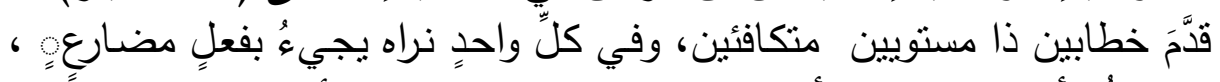

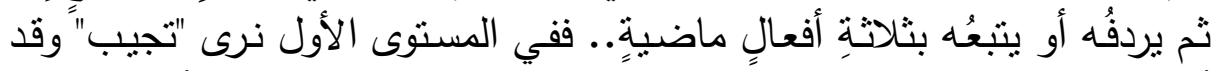

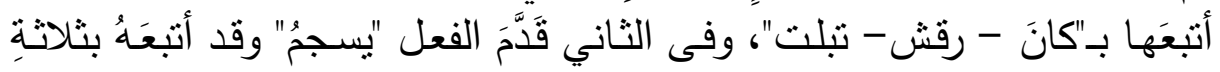

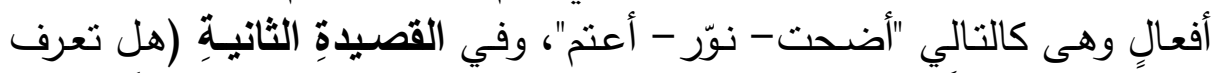

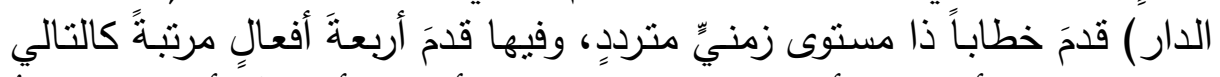

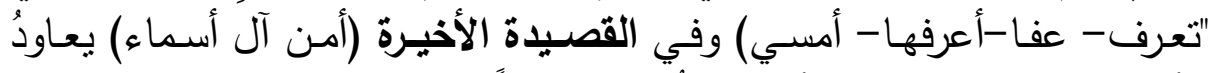

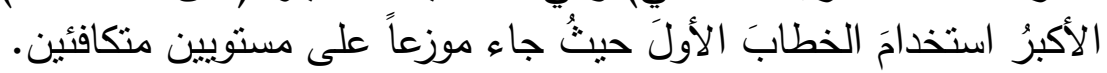

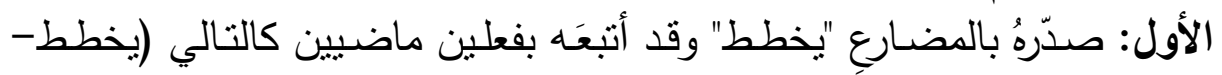
ذكرت- دبستي). 


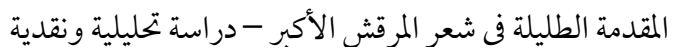

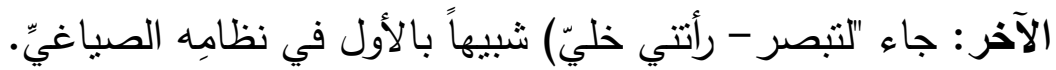

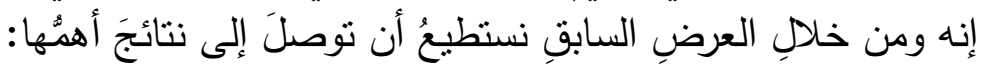

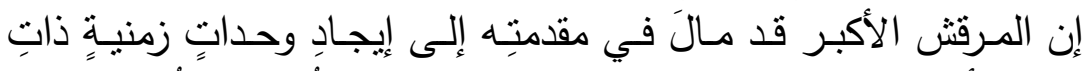

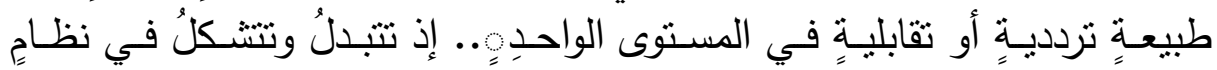

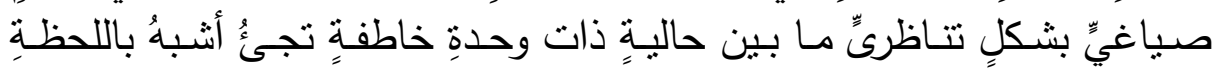

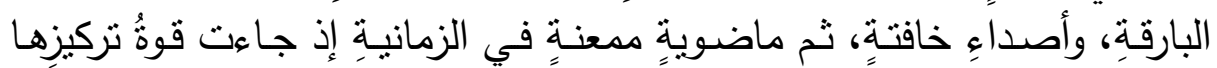

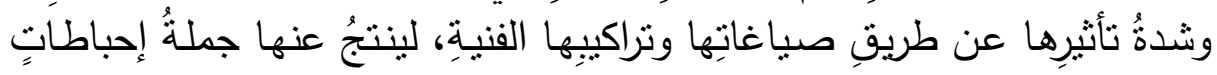

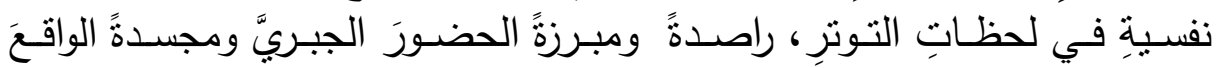

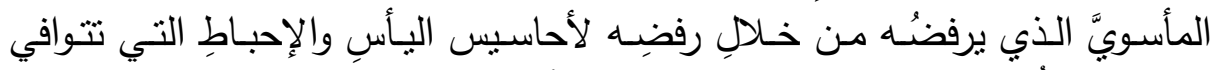

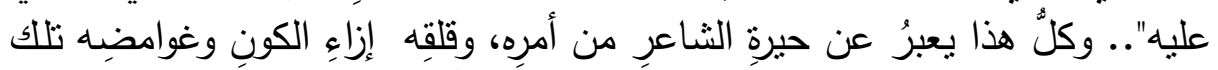

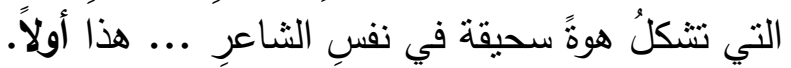

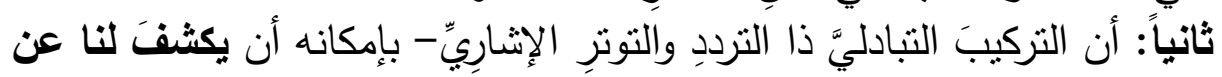
أمرين: أن أنزين

الأول: طبيعهِة الصراع الجدليِّ القائم بينَ المَاضي والحاضر ، وذلك في الدوائرِ

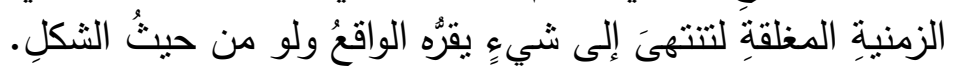

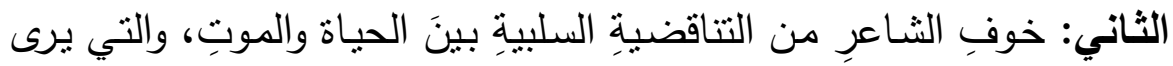

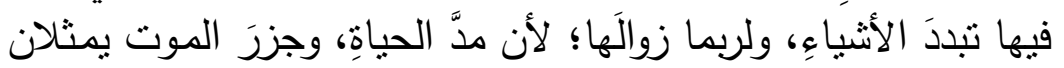

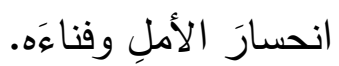

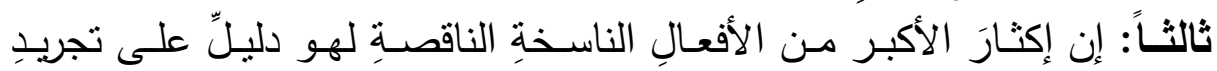

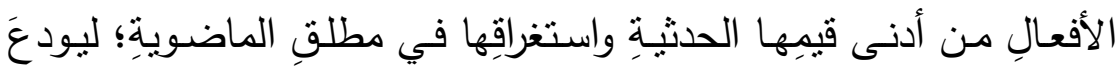

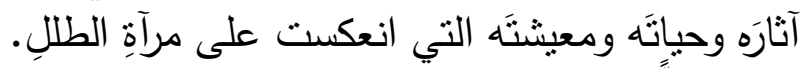

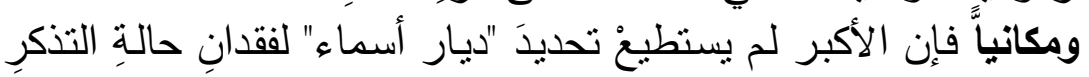
الكبرى والصغرى. - مئ. 
= المجلد الأول من العدد الخامس والعثرين لحولية كلية الاراسات الإسلامية والعربية للبنات ـ بالإسكندرية ع ب

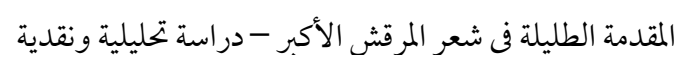

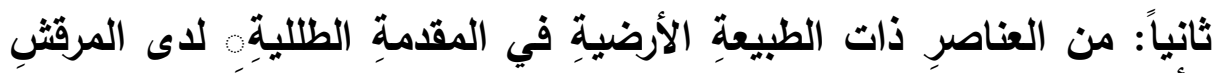
الأكبر:

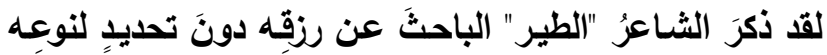

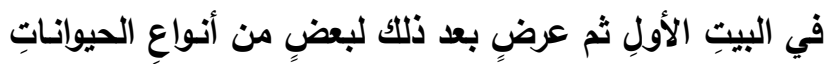
حيثُ جاءت مرتبةُ كالتالي:

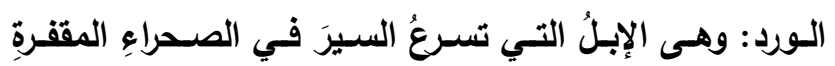
الثاسعةِ الأبعادِ

العيس: جـع أعيس وعيساء وهي الإبلُ البيضُ التي يخالطُ بياضَها شيءُ من الشقرة.

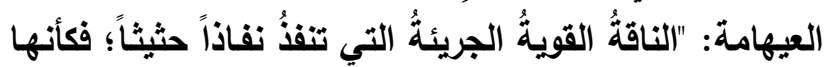
تنسلُ من جلدها، وذلك في دامسِ الليلِ.

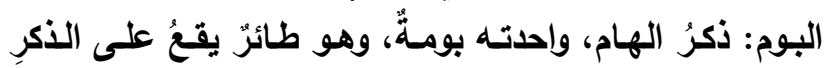

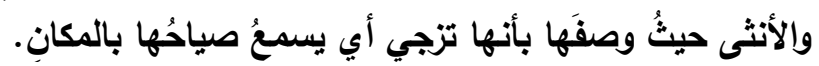

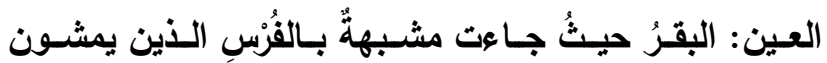

$$
\text { بالقلانسِ متبخترين. }
$$

النعم: قد تكونُ بمعنى عليهم النعم، أي الخيرات، وقدا يكونُ

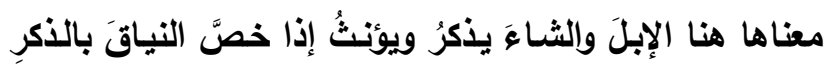

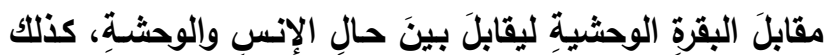

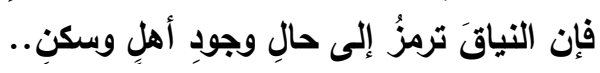

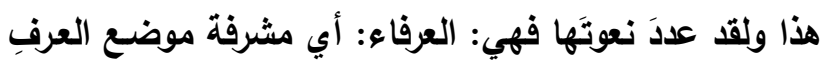

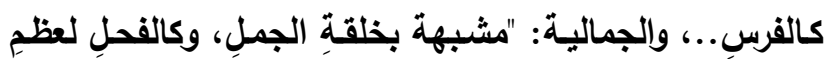

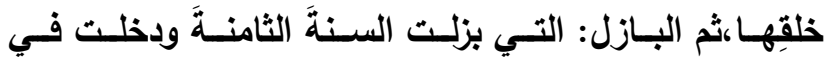
التاسعة. الظعن: مركبُ الحبيبةِ وهنا شبَّهُ الجمالَ وعليها هوادجُ النسـاعِ

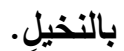
البهه: جمع بهمة وهى الصغيرةُ من ولدِ الغتم.

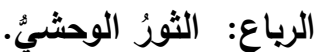




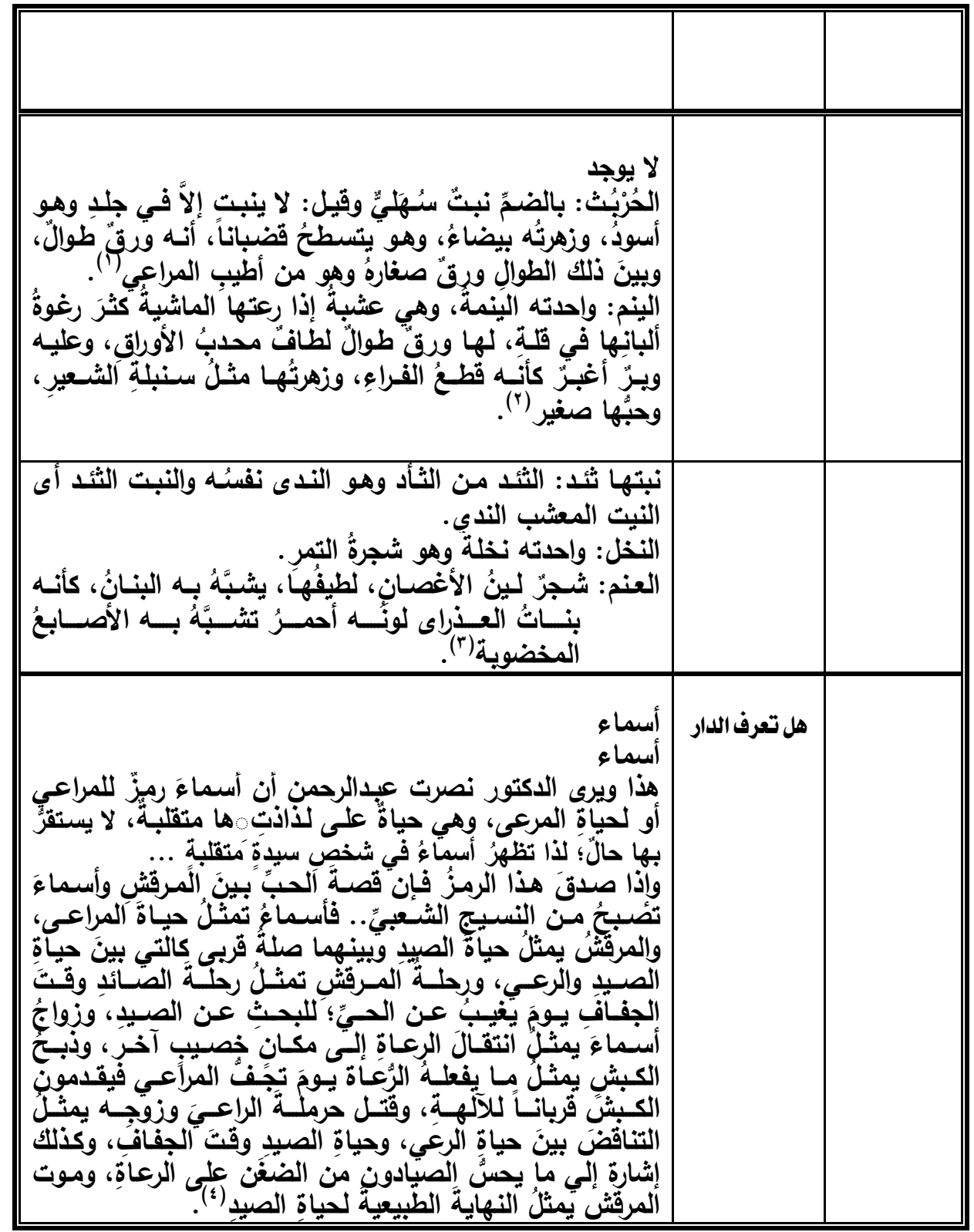

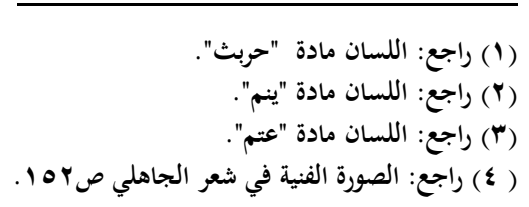




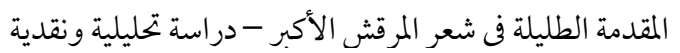

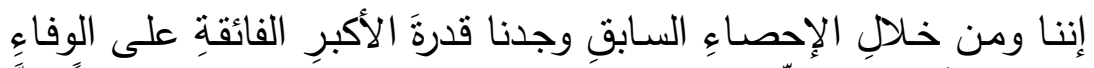

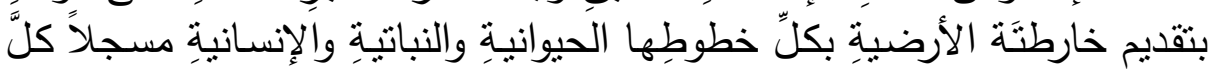

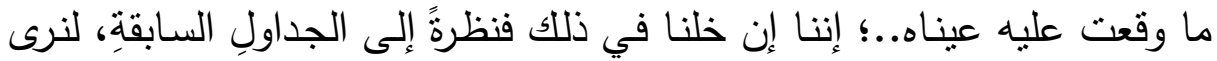

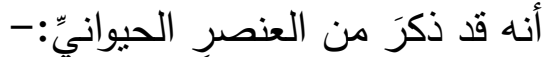

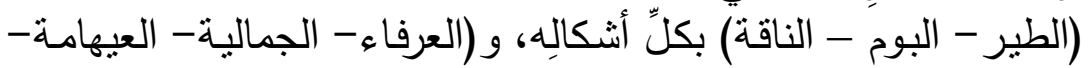

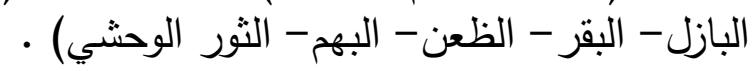

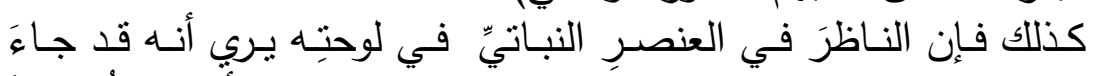

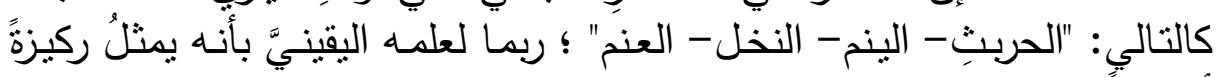

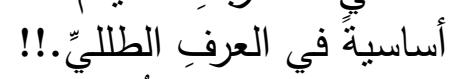

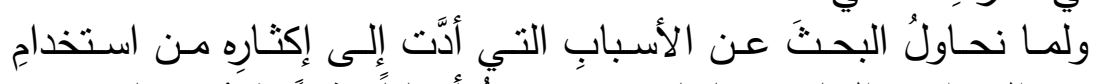

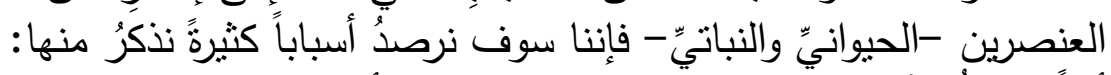

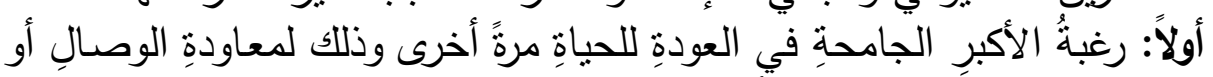

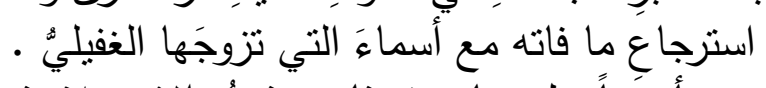

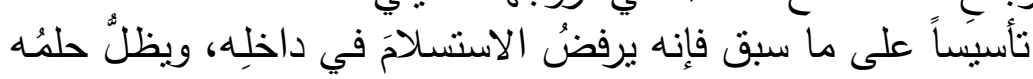

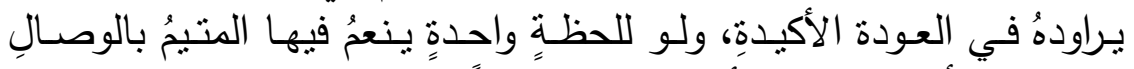

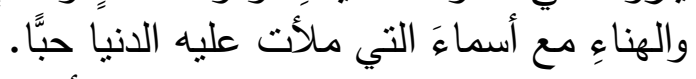

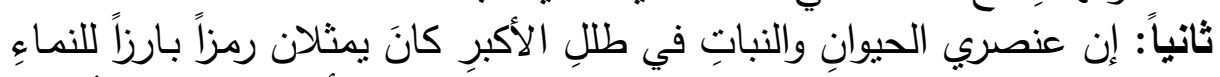

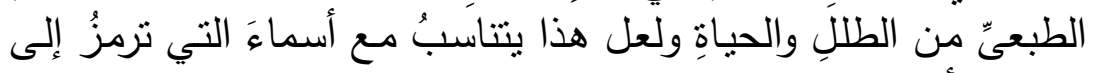

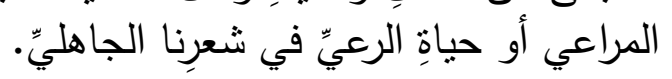

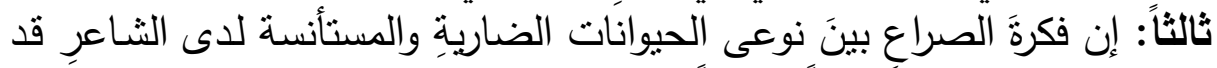

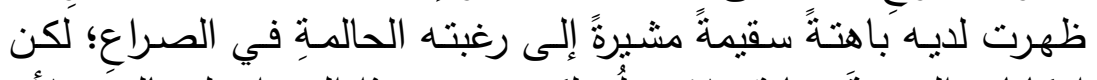

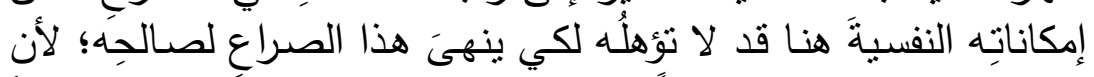

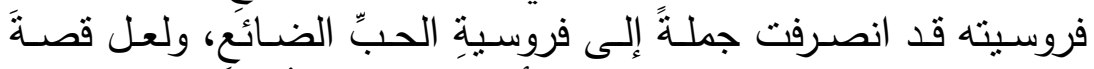

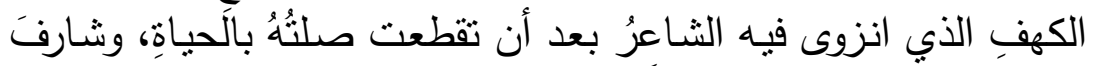

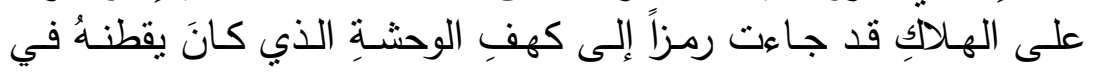

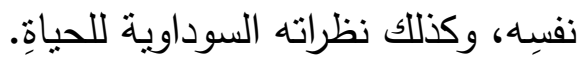

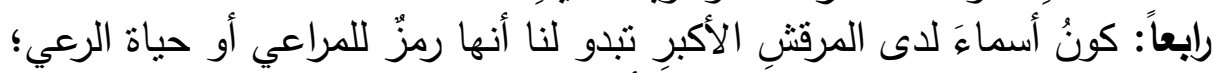

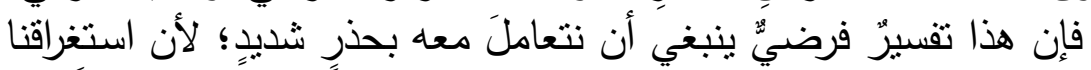

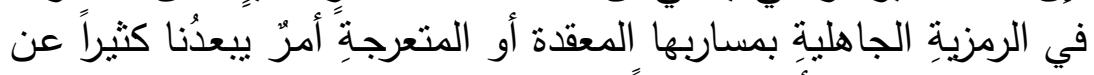

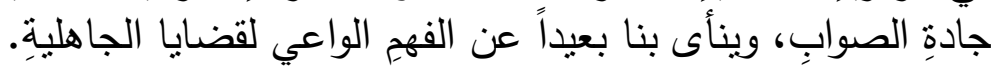




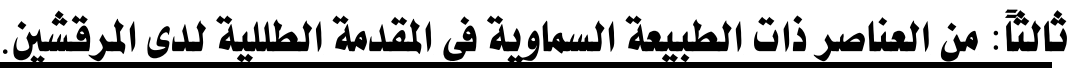

\begin{tabular}{|c|c|c|}
\hline المرقش الأكبر & اسم القصيدة & طرة طليعة \\
\hline لا توجد & في القصائد كلها & السهاs \\
\hline نبتها ثلثد الندي نفسه & هل باللديار & المطر \\
\hline 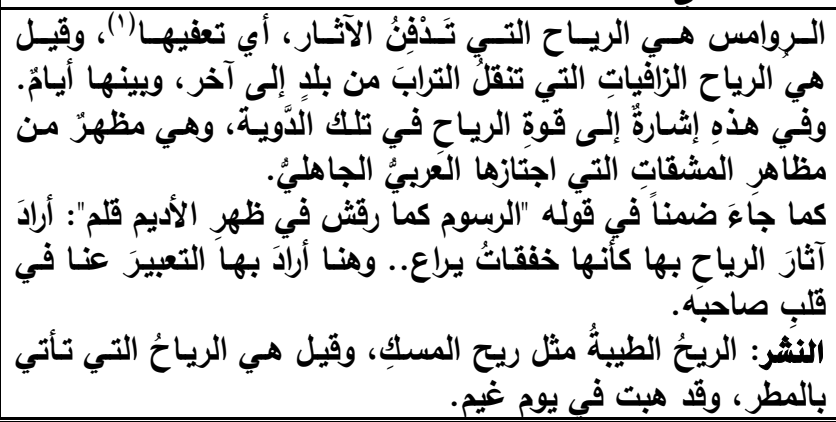 & 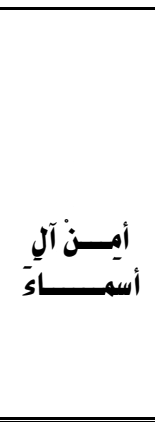 & الرياح \\
\hline
\end{tabular}

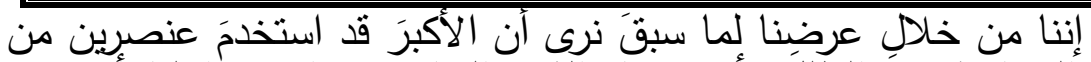

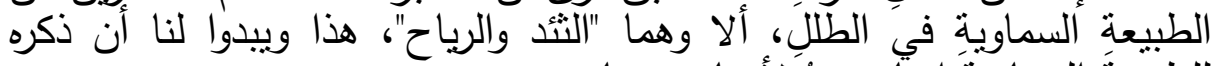

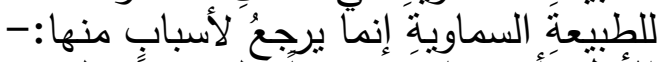

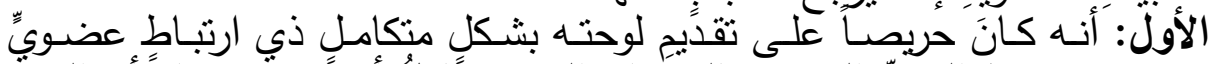

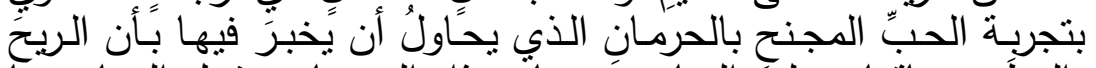

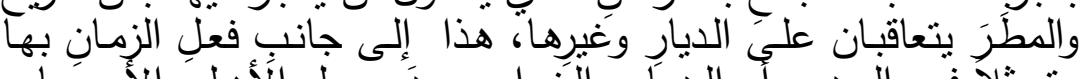

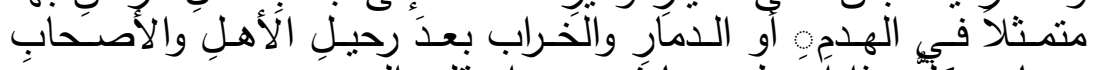

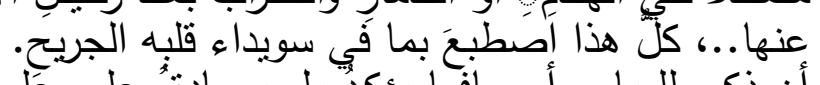

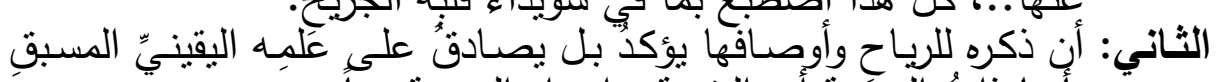

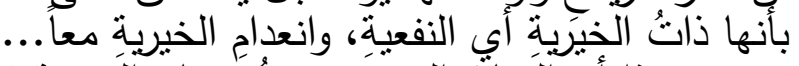

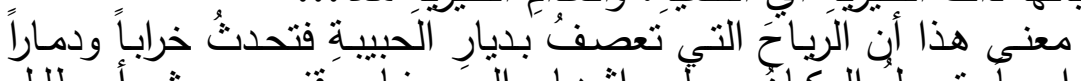

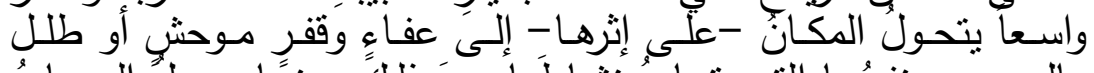

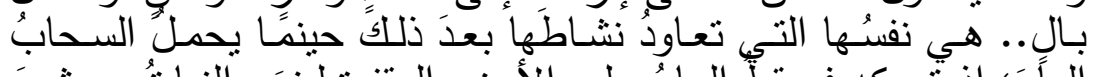

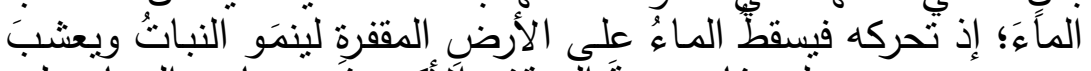

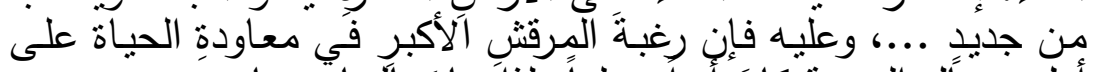

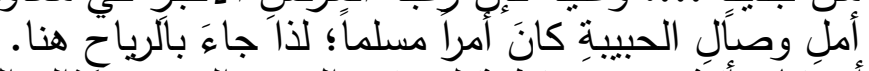

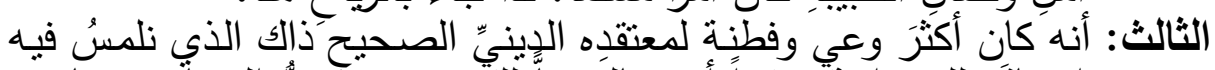

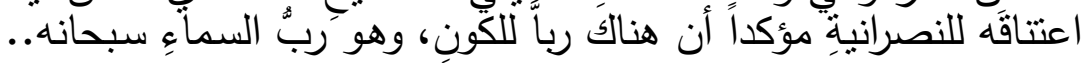




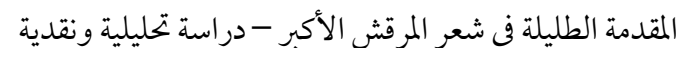

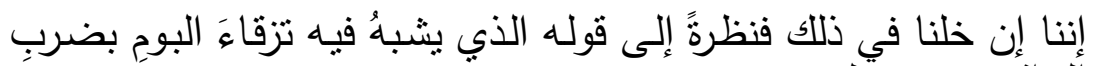

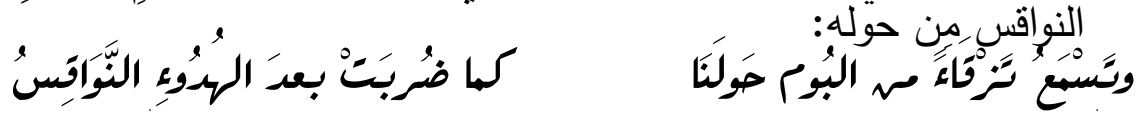

المحورُ الآخرُ : أنماطُ قصائد الطلل وسماتُها البنائيةُ والقنيةُ عند

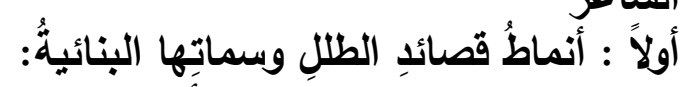

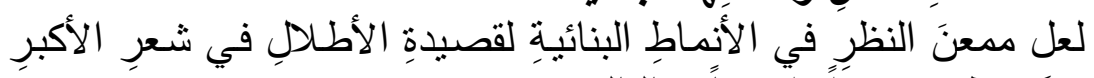

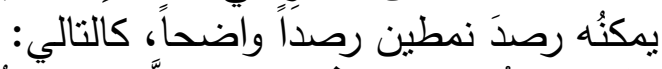

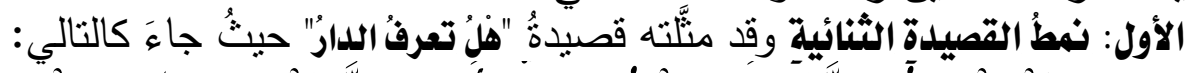

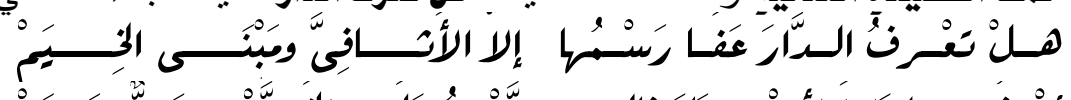

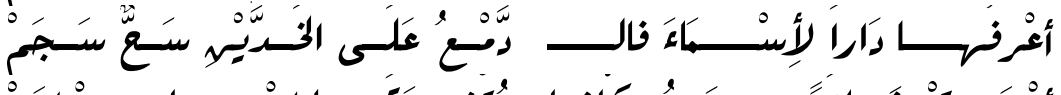

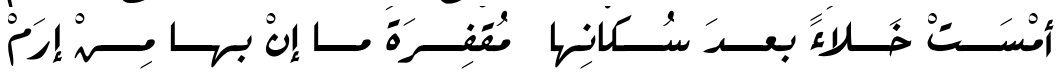

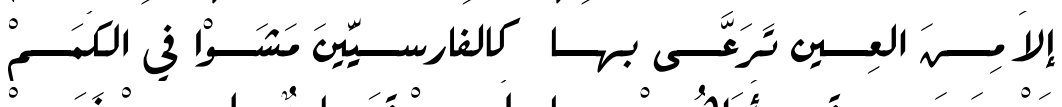

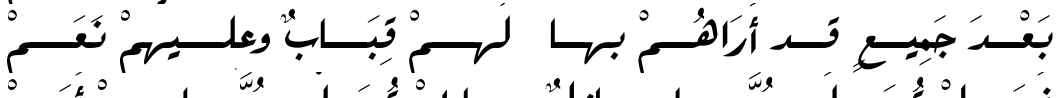

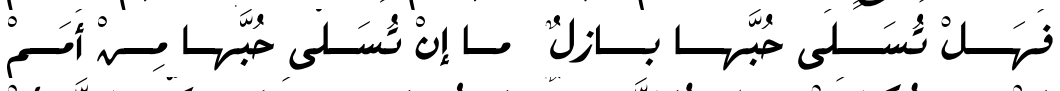

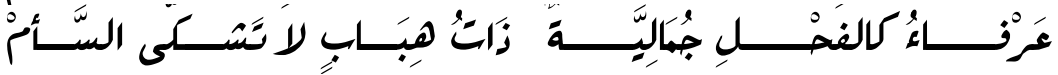
فرأينا:

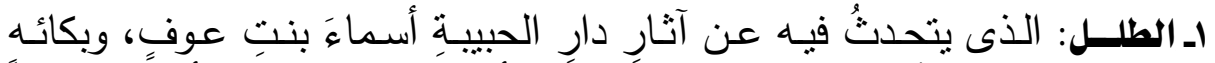

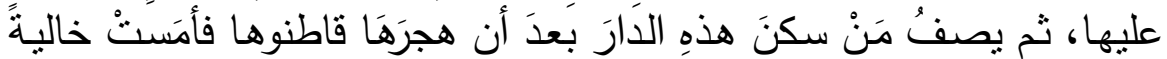

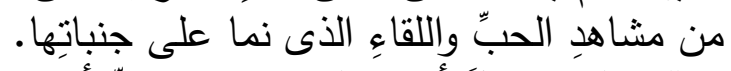

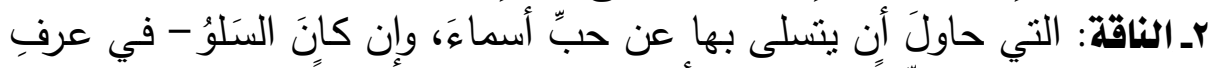

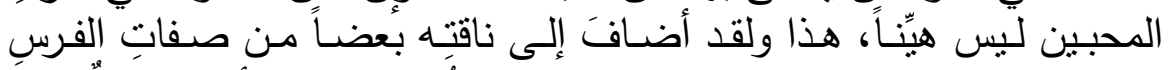

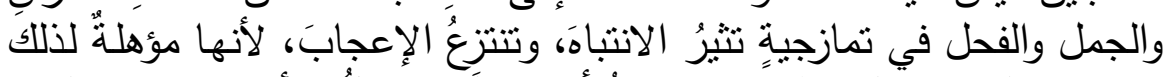

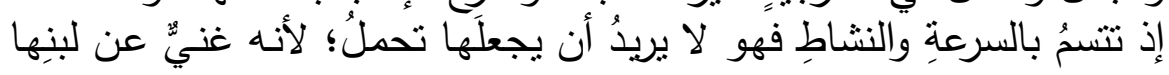

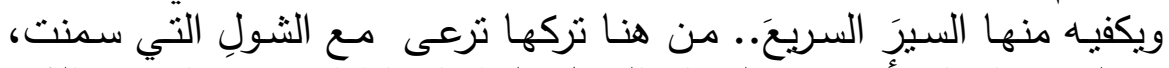

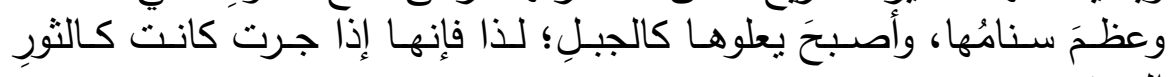

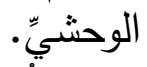

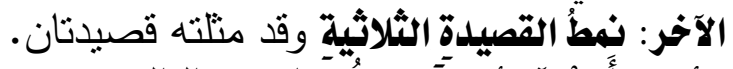

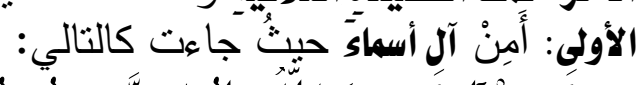

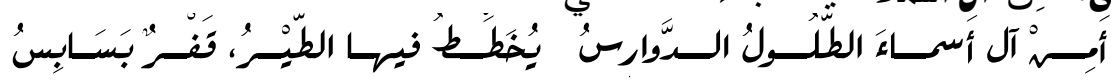




\section{المقدمة الطليلة في شعر المرقش الأكبر - دراسة تحليلية ونقدية}

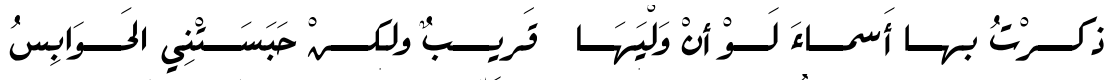

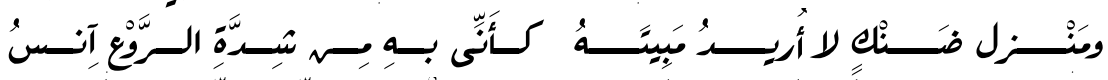

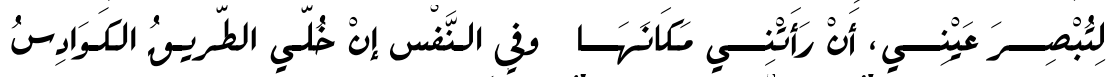

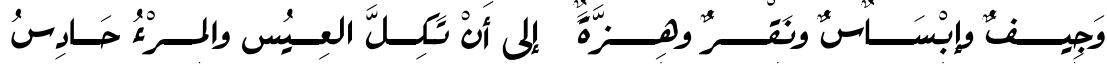

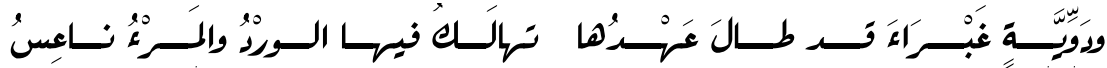

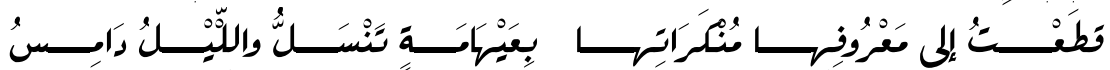

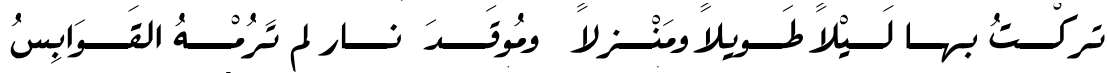

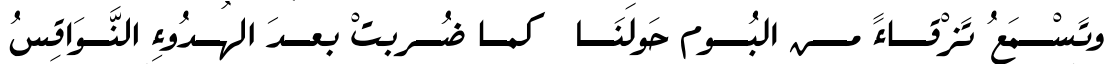

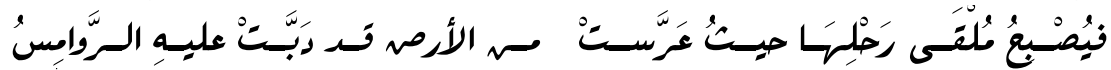

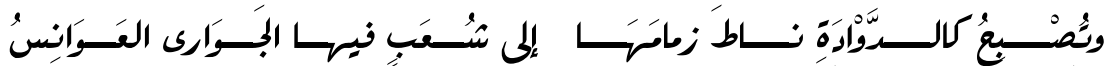

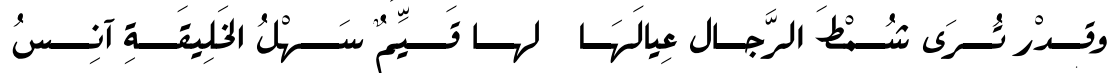
فرأينا:

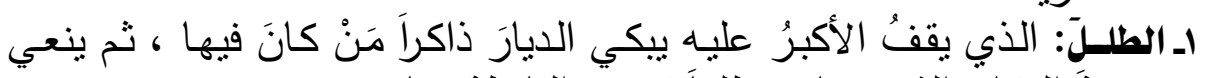

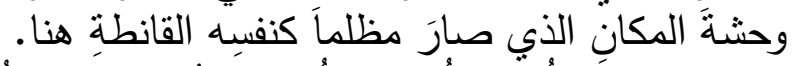

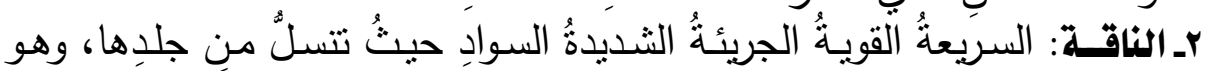

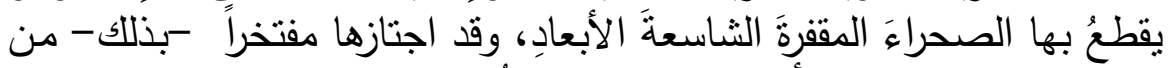

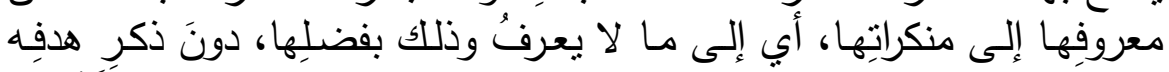

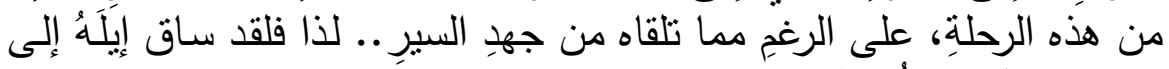

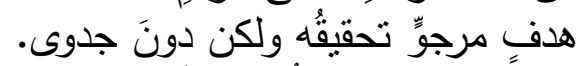

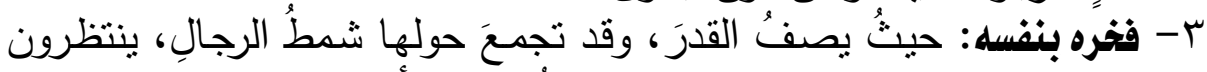

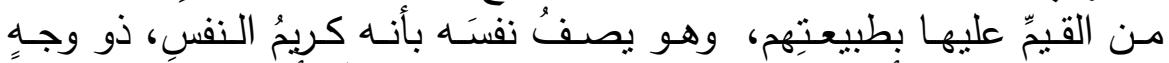

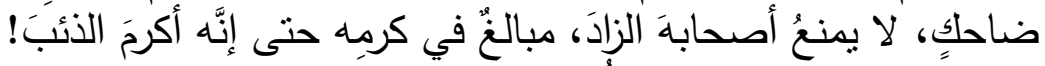

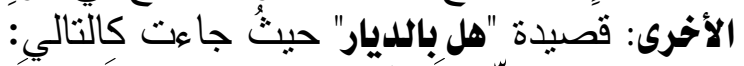

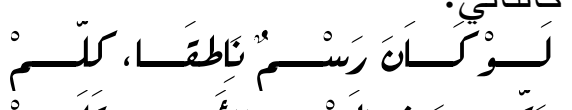

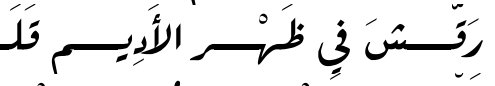

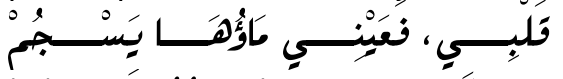

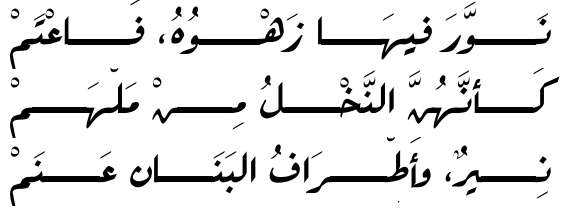

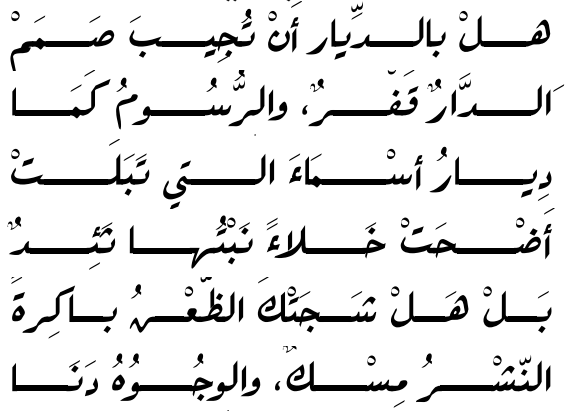




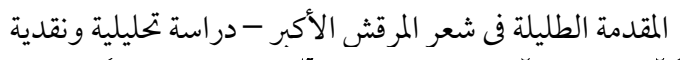

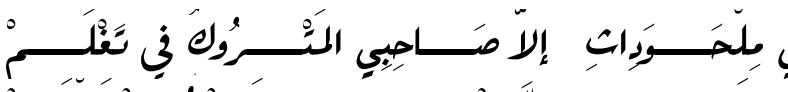

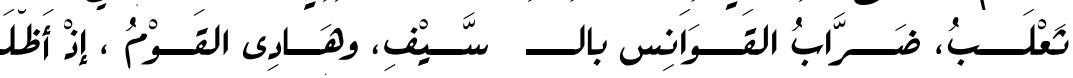

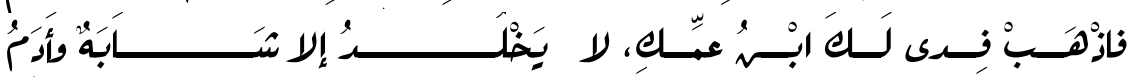
فرأينا:

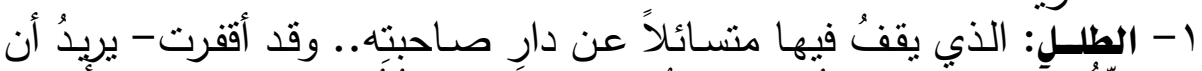

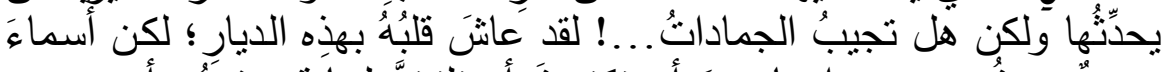

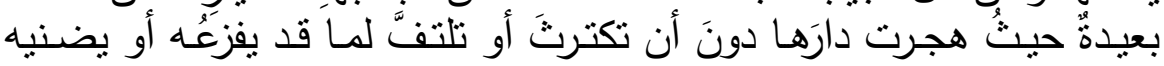
لفراقِها.

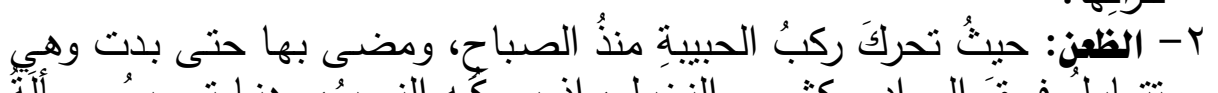

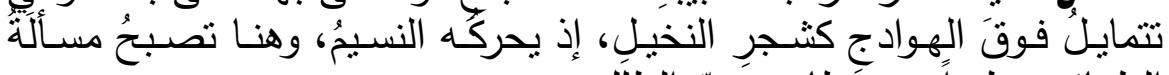

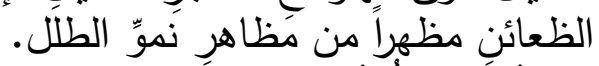

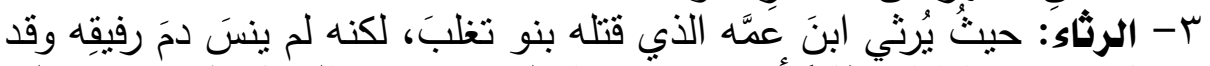

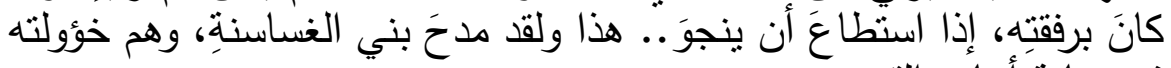

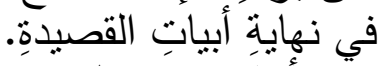

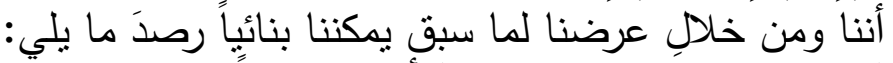

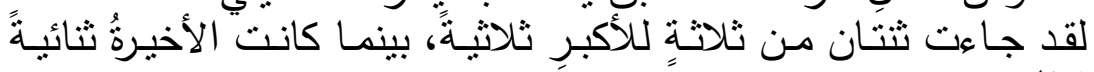

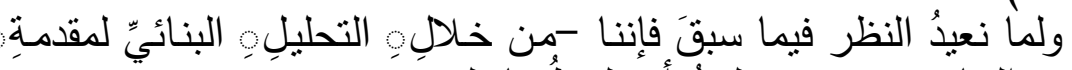
(طلل وناقة)

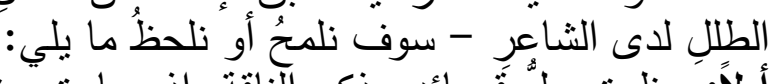

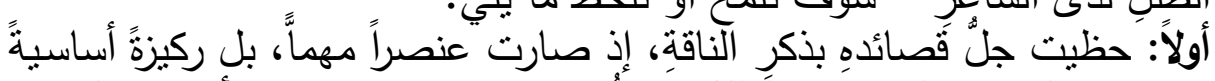

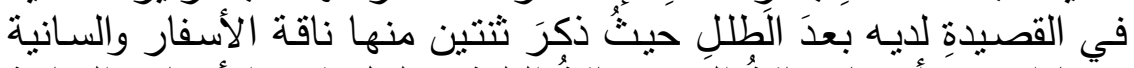

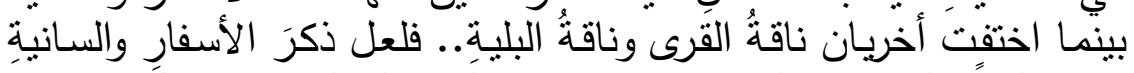

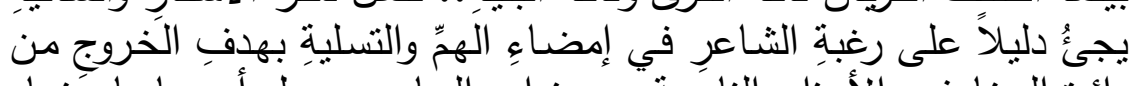

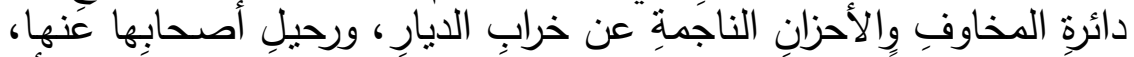

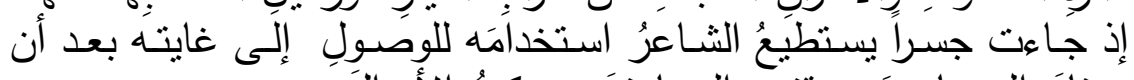

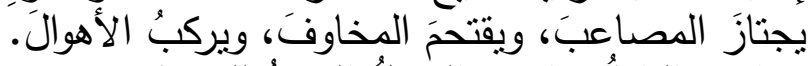

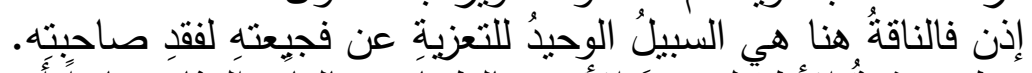

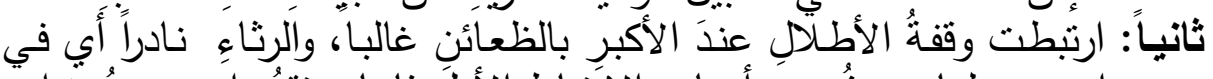

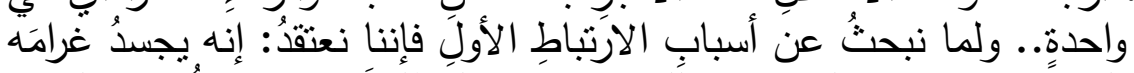

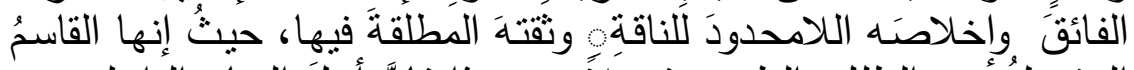

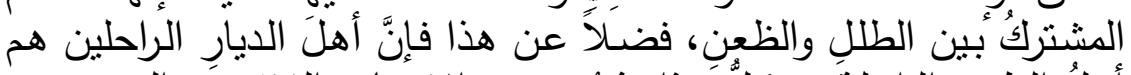

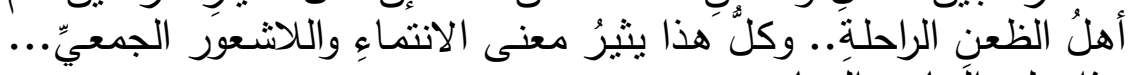
هذا على الَجانبِ الَّياتِِّ. 


\section{المقدمة الطليلة فى شعر المرقش الأكبر - دراسة تحليلية ونقدية}

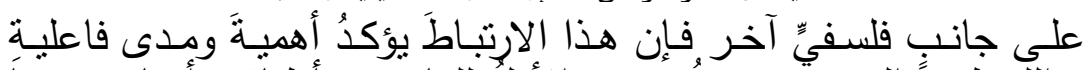

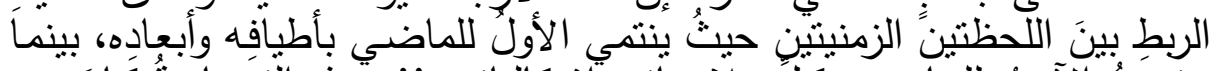

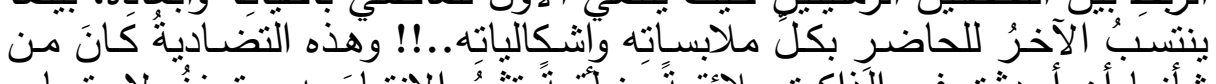

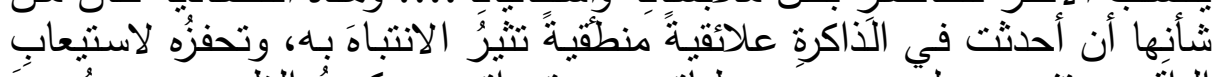

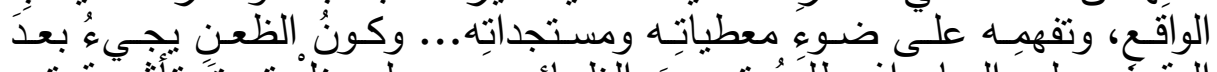

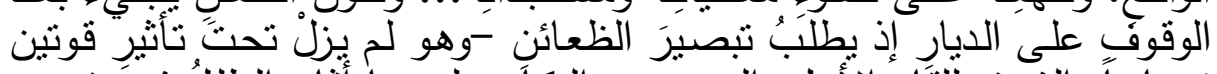

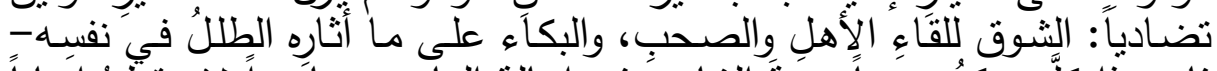

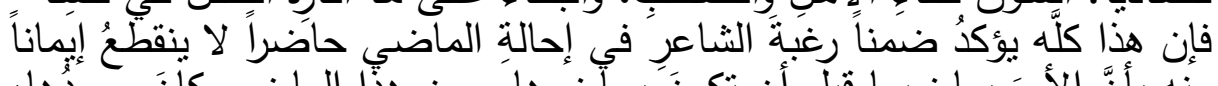

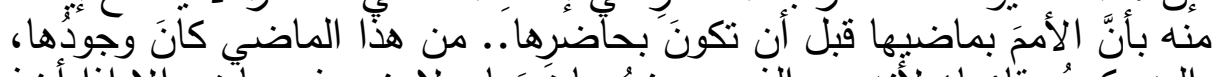

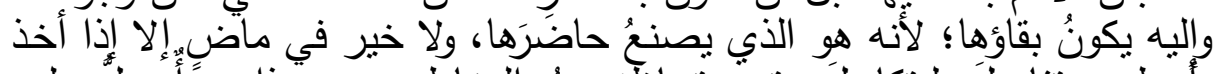

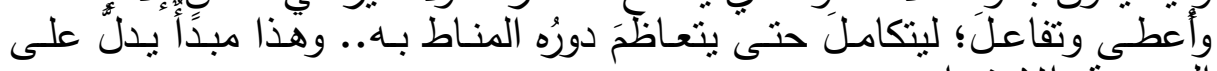

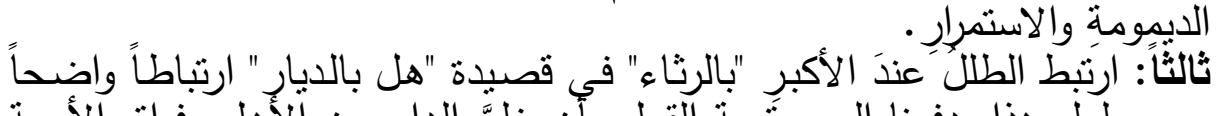

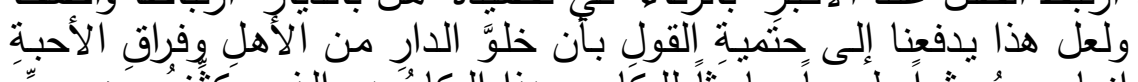

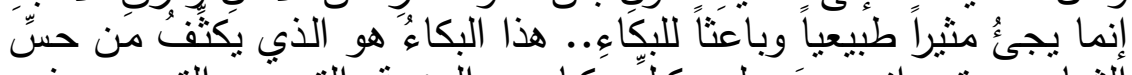

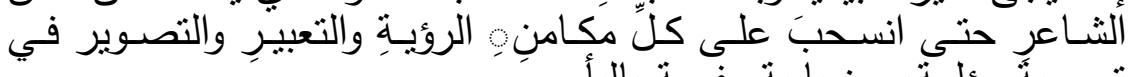

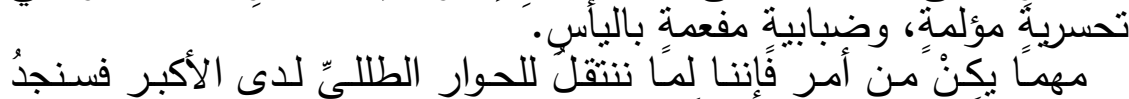

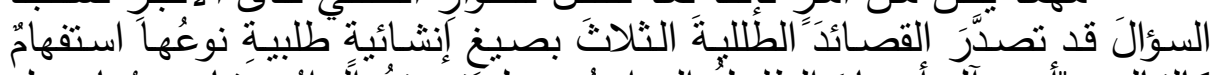

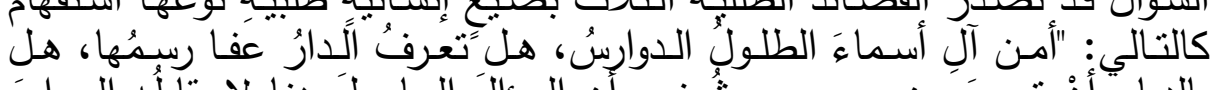

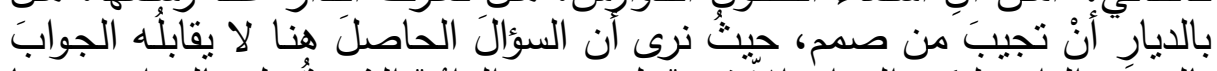

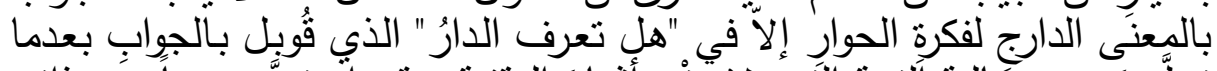

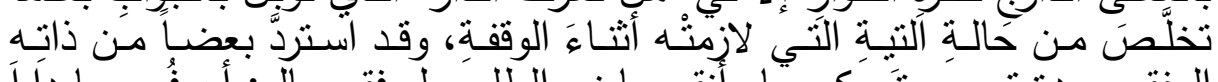

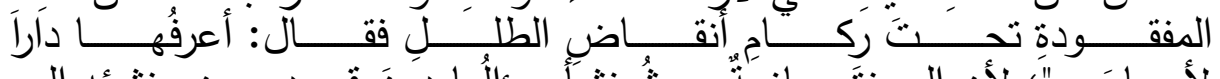

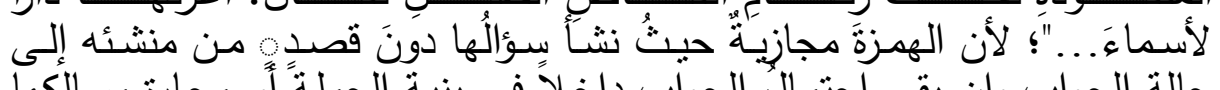

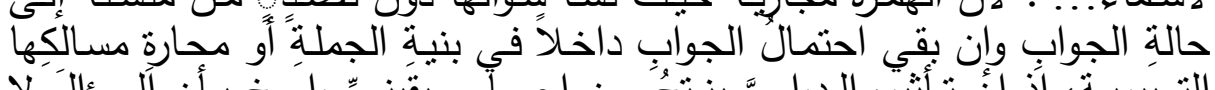

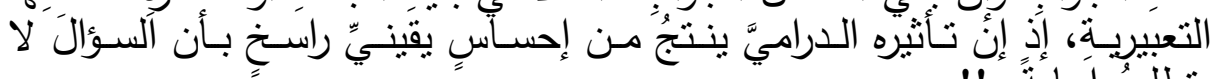

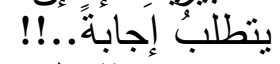

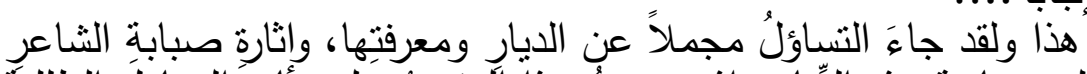

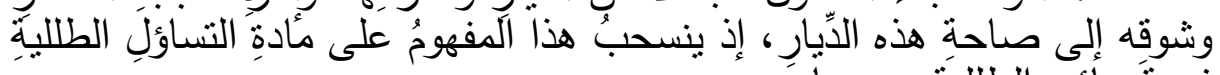

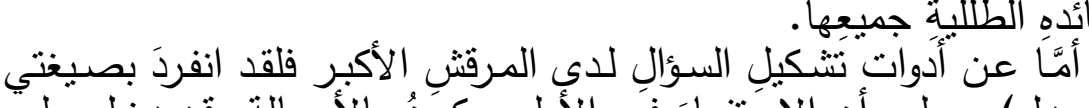

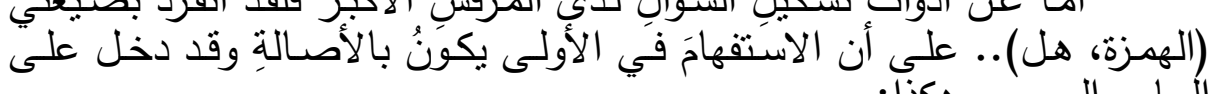

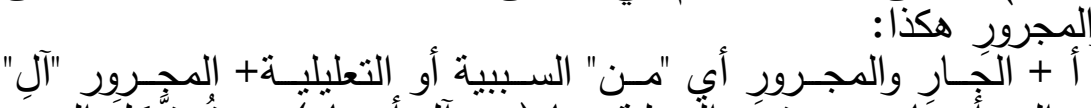

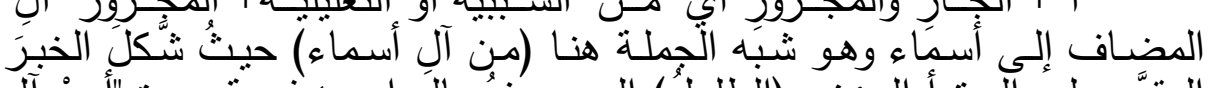

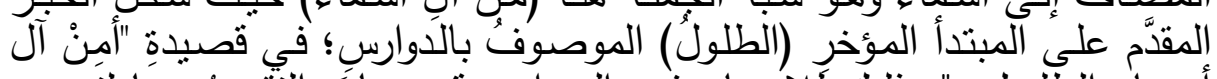

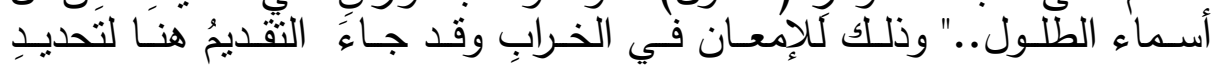




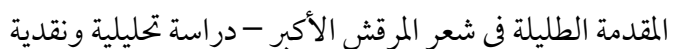

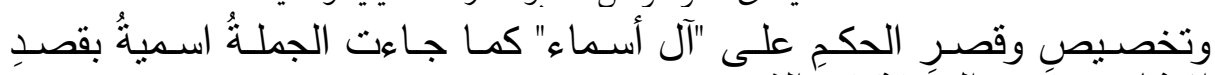

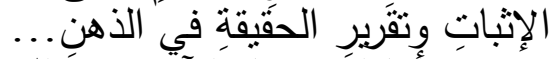

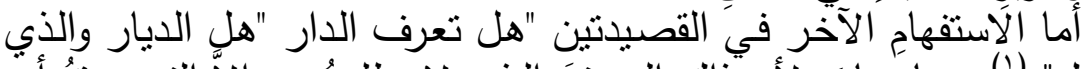

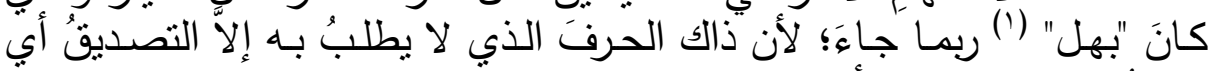

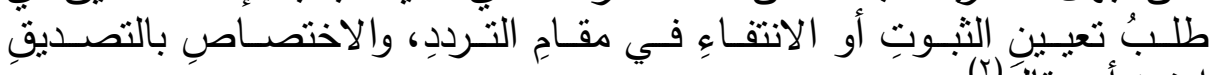

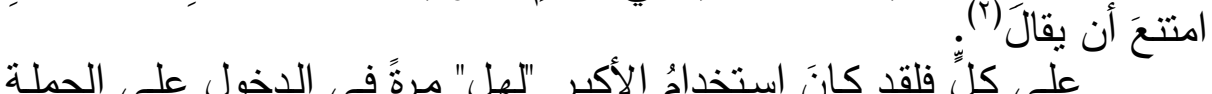

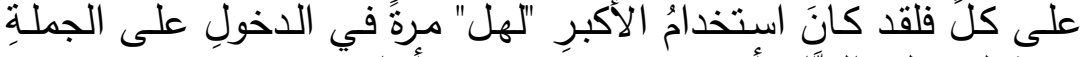

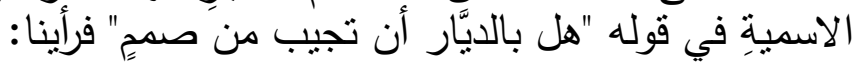

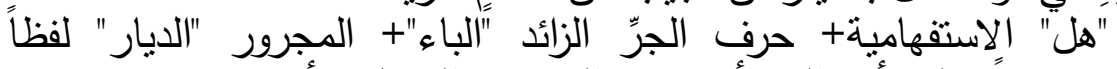

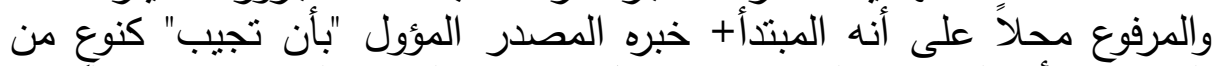

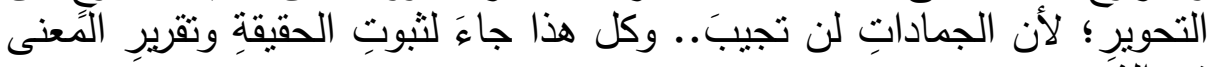

وجًاءت مرةً أخرى بالحدوثِ وذلك عندما دخلت على الجملة الفعلية في

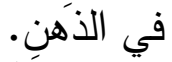

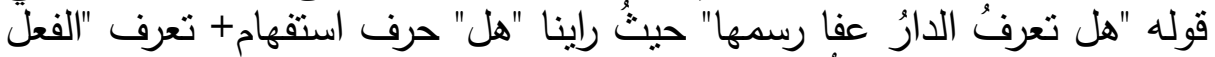

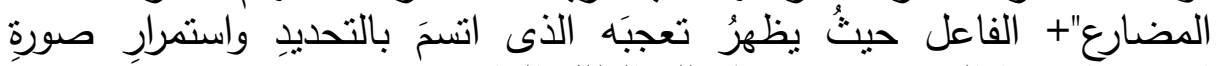

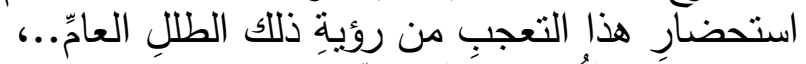

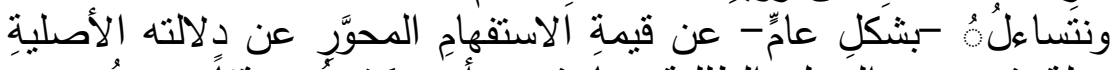

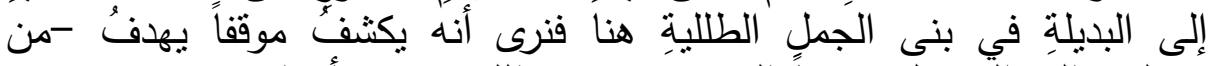

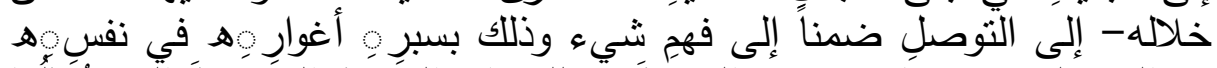

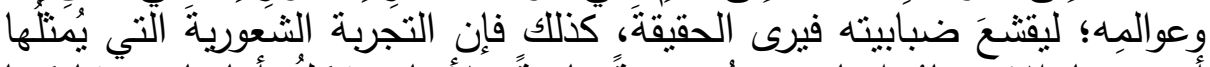

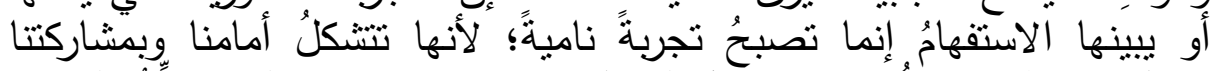

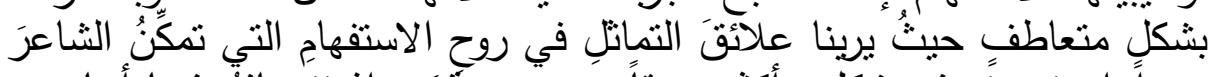

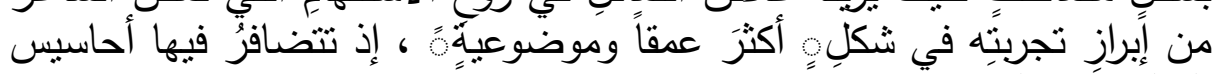

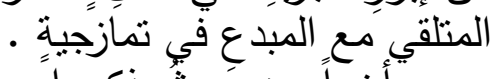

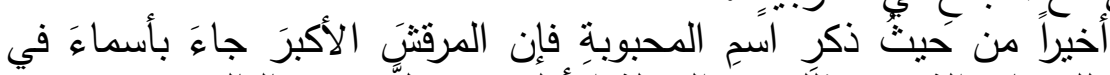

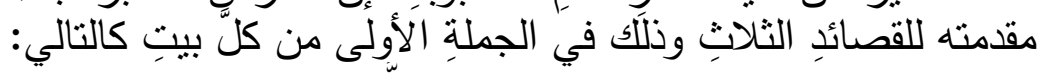

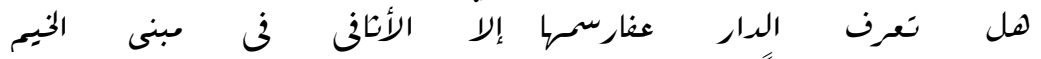

$$
\text { وفي الثانية: }
$$

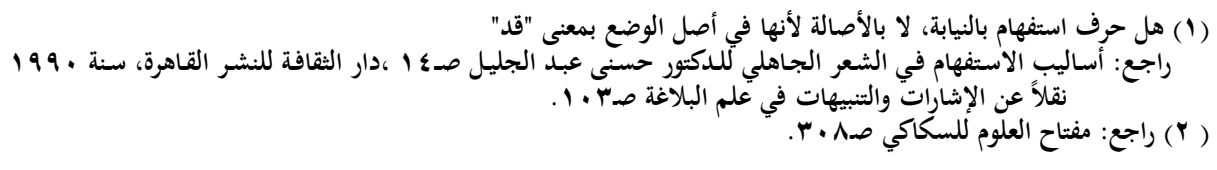


= المجلد الأول من العدد الخامس والعشرين لحولية كلية الدراسات الإسلامية والعربية للبنات ـ بالإسكندرية سـ المقدمة الطليلة فى شعر المرقش الأكبر - دراسة تحليلية ونقدية

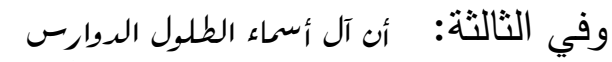




\section{المقدمة الطليلة في شعر المرقش الأكبر - دراسة تحليلية ونقدية}

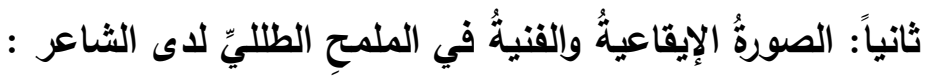

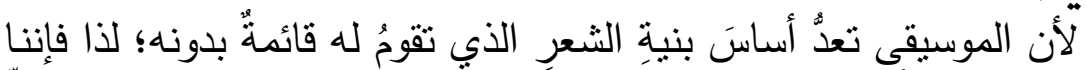

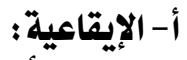

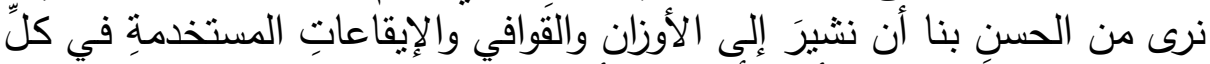

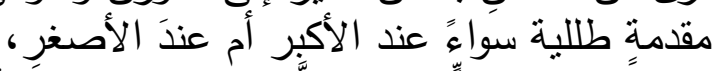

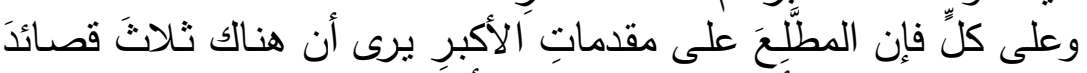

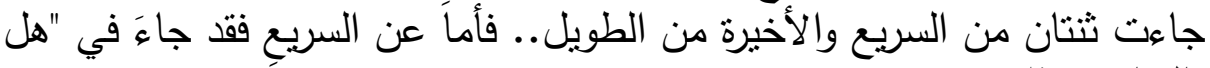

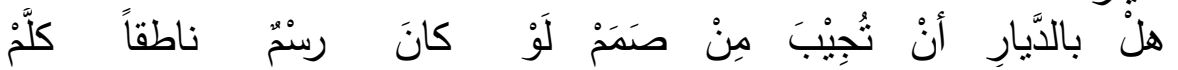

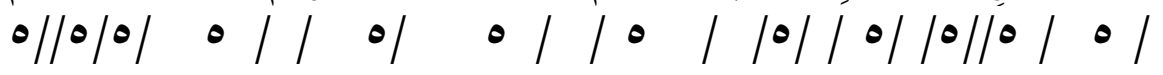
مستفعلن متفعلن متفعلن

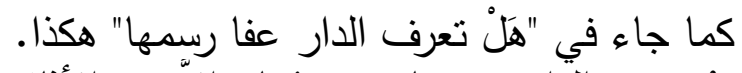

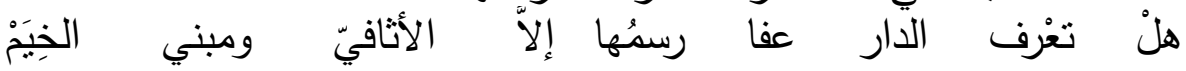
$\bullet / / \bullet /$
$\bullet / / / \bullet /$
$\bullet / / \bullet / \bullet /$
$\bullet / / \bullet /$
$\bullet / / \bullet / \bullet / /$
$\bullet / \bullet /$

مستفعلن مستعلن فاعلن مستفعلن مستعلن فاهن فاهن

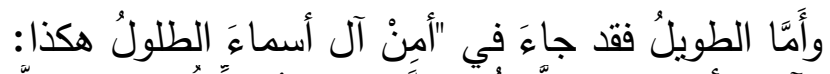

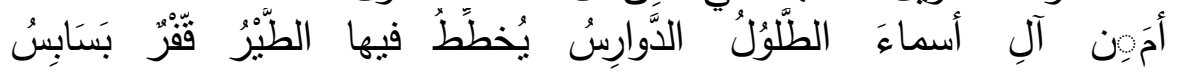

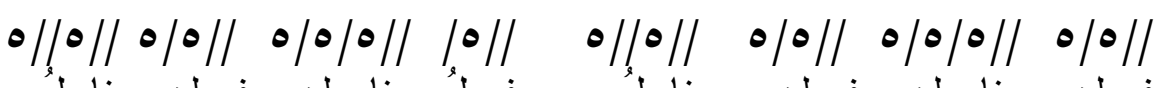

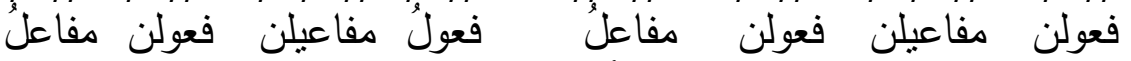

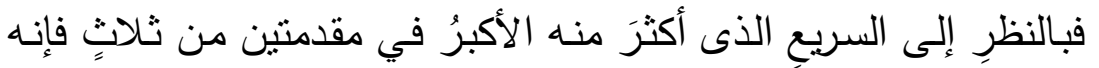

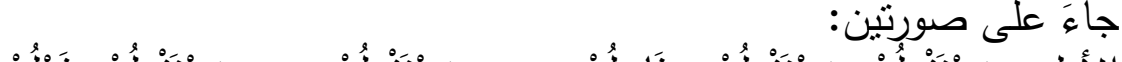

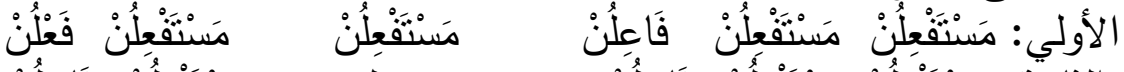

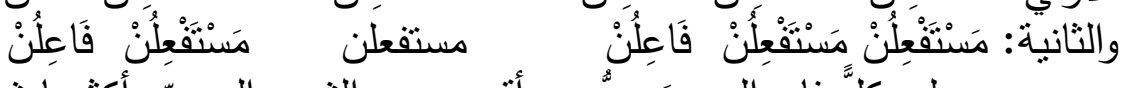

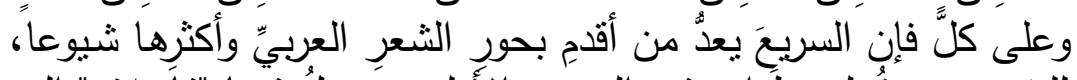

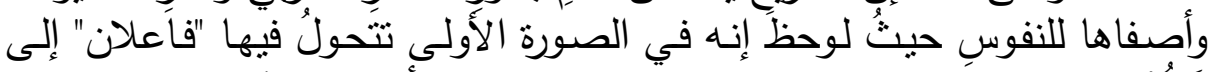

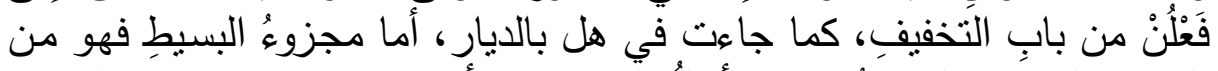

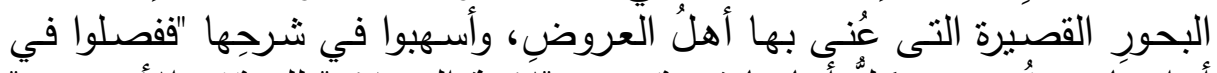

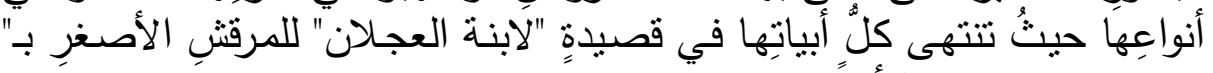

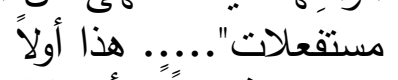

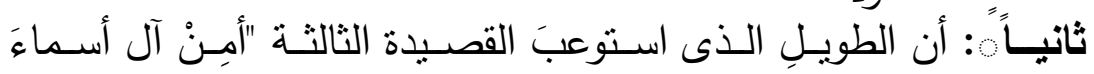

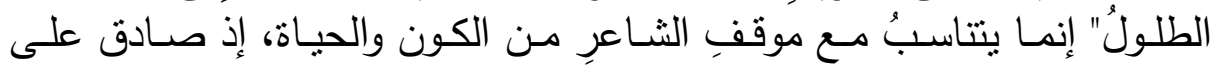




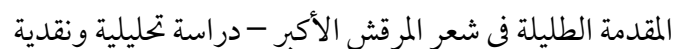

رغبته فى إيجادِ وحداتٍ موسيقيةٍ متساوية يتحققُ من خلالها إتباعيةٌ ذاتُ قيمةٍِ فنيةٍ عاليةٍ

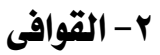

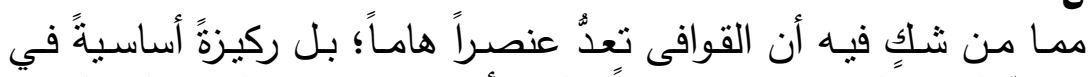

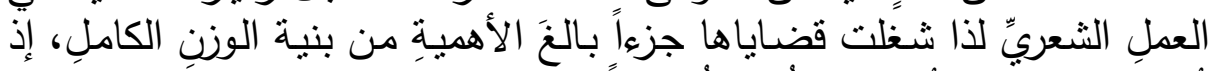

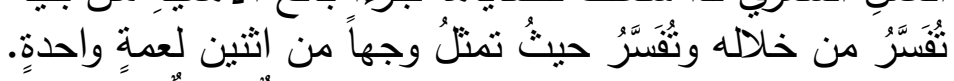

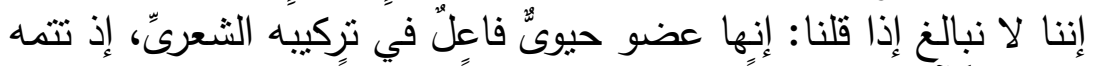

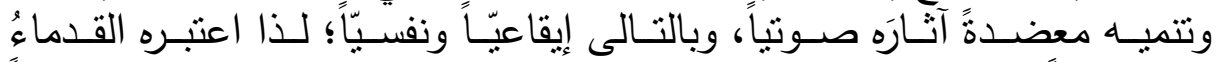

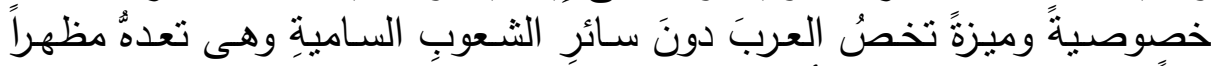

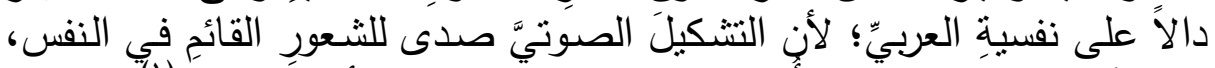

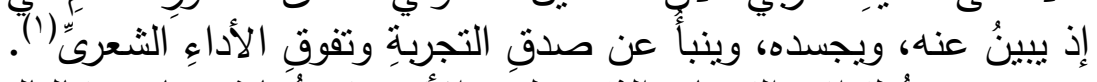

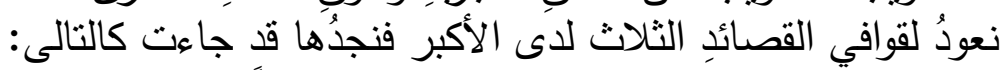

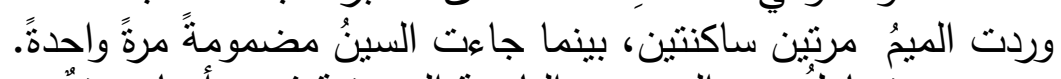

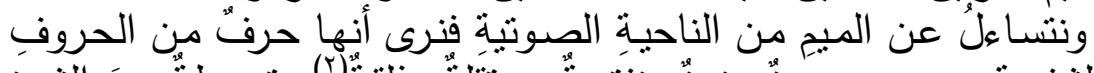

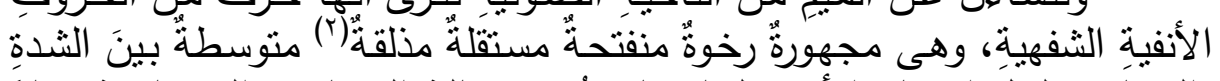

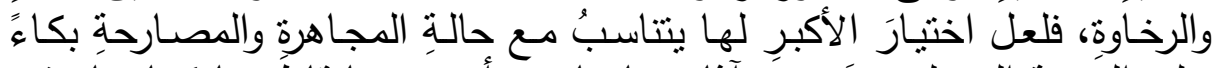

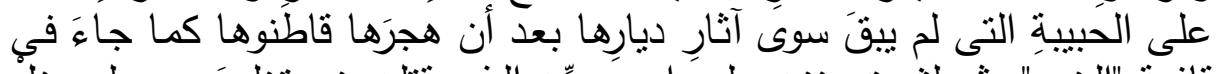

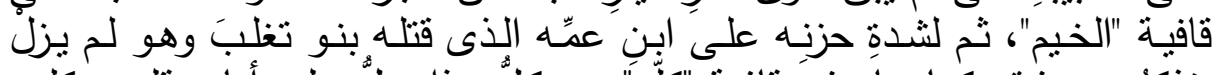

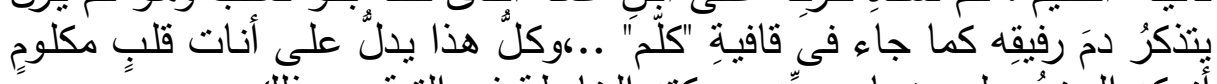

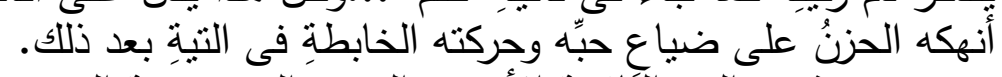

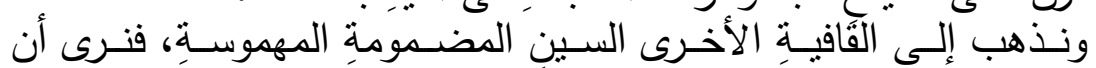

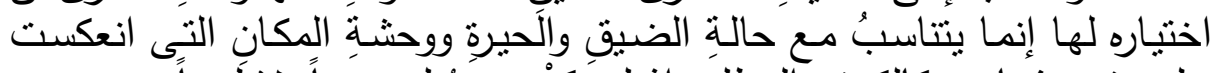

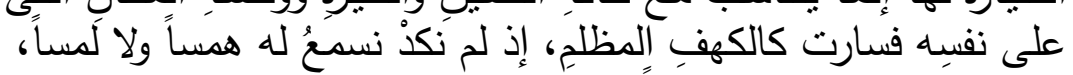

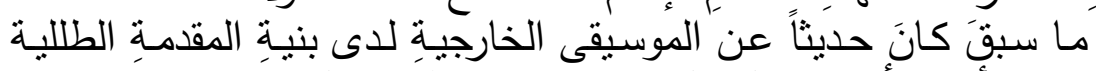

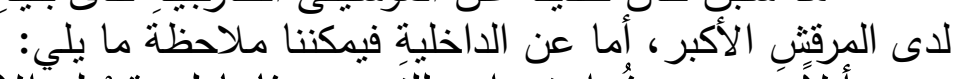

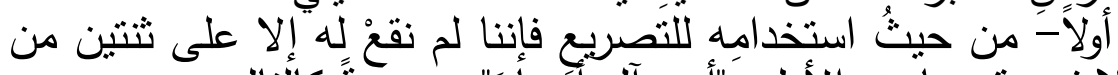

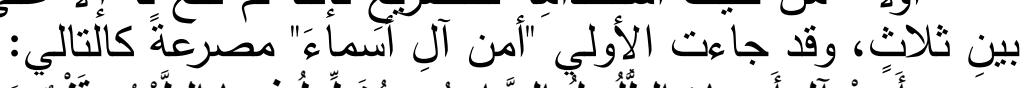

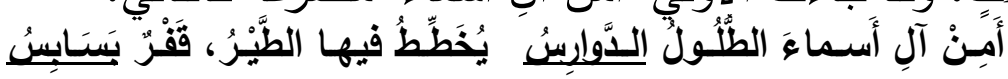

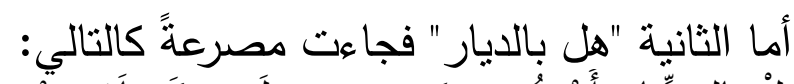

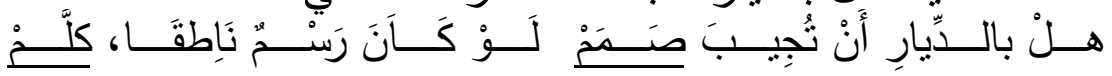




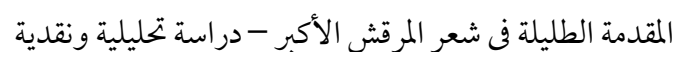

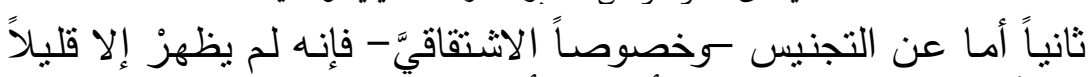

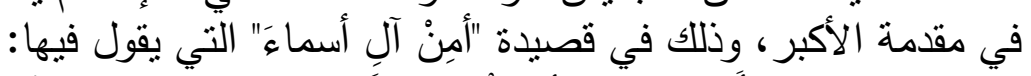

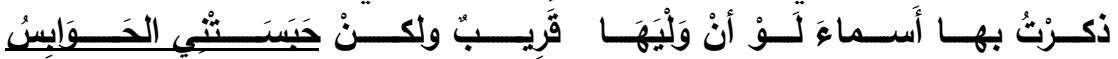

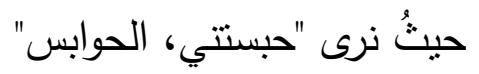

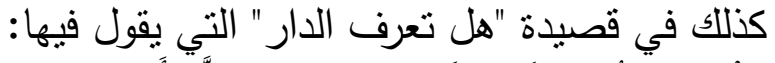

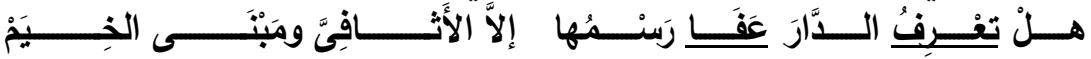

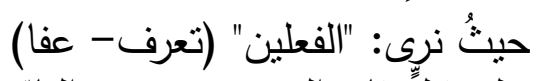

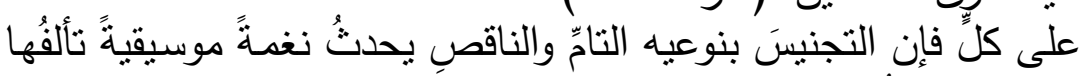

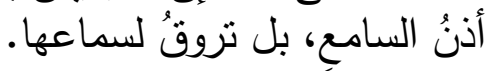

بـ الصورة الثفنية:

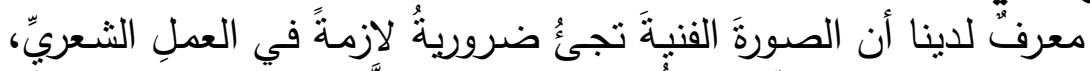

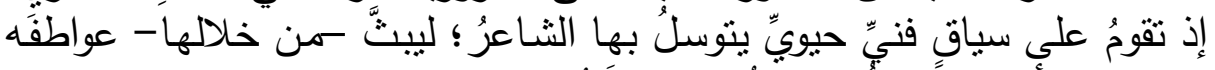

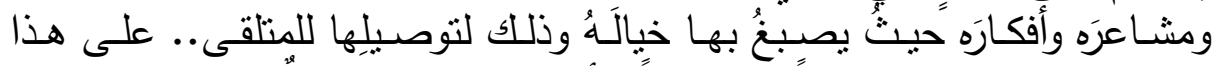

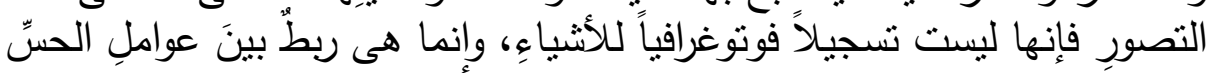
المختلفة

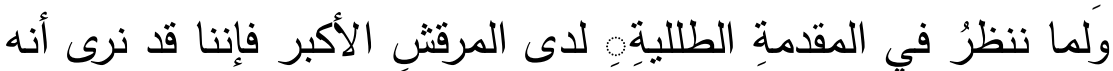

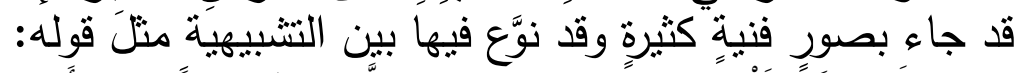

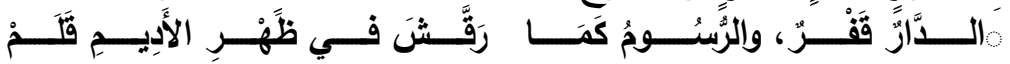

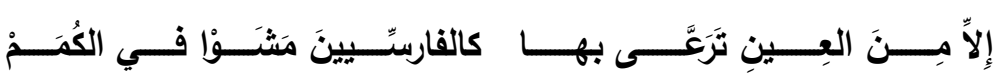
وقوله:

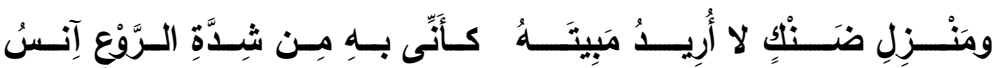
وقوله: وهناك الاستعارية منل قوله:

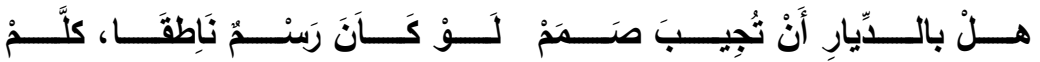

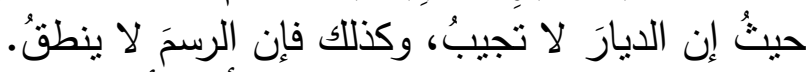

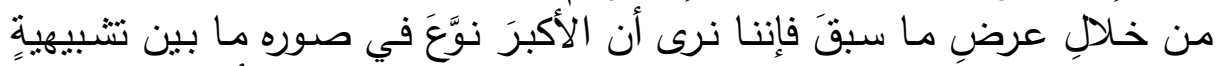

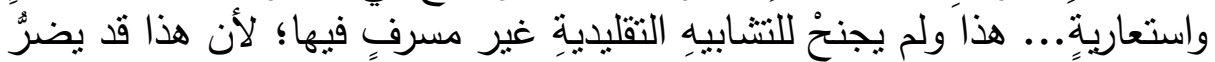

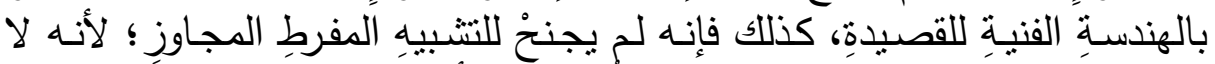

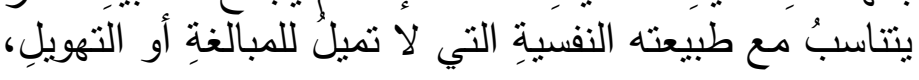


= المجلد الأول من العدد الخامس والعثرين لحولية كلية الدراسات الإسلامية والعربية للبنات - بالإسكندرية سل المقدمة الطليلة فى شعر المرقش الأكبر - دراسة تحليلية ونقدية

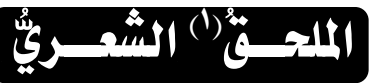

القصيدة الأولى: يقول المرقش الأكبر:

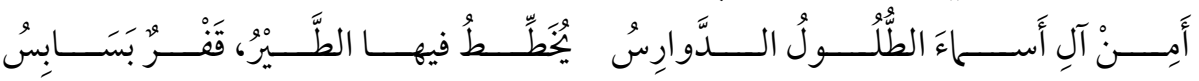

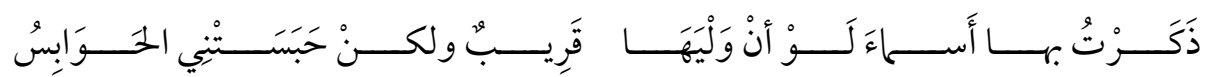

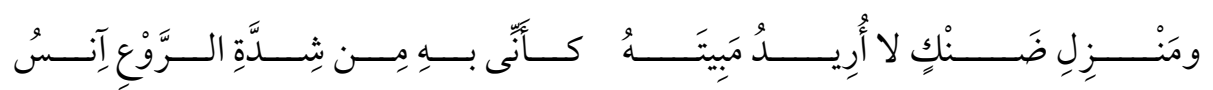

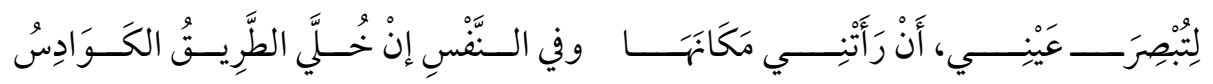

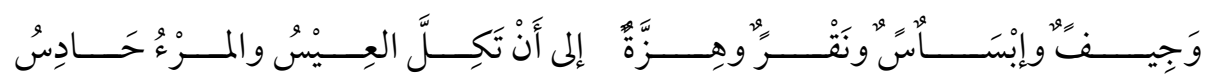

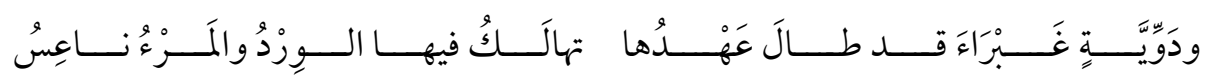

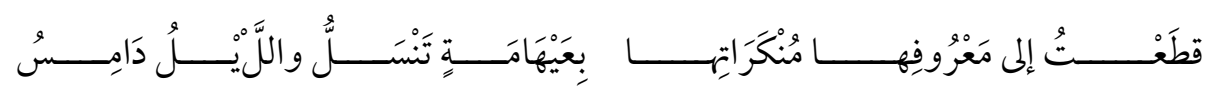

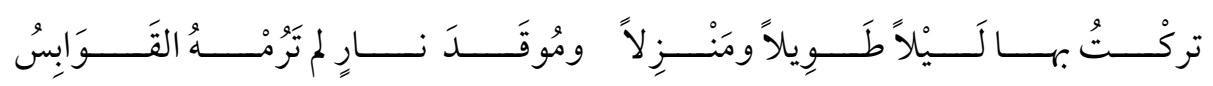

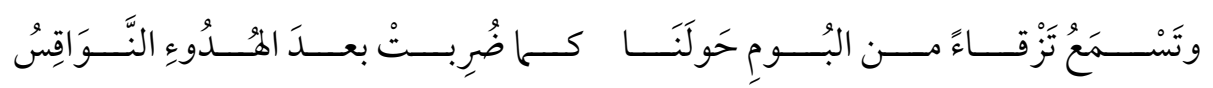

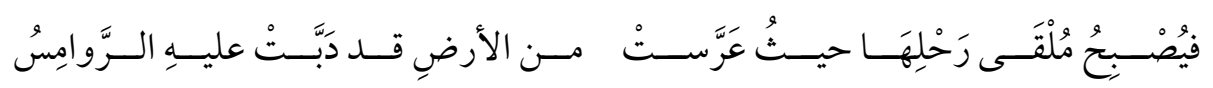

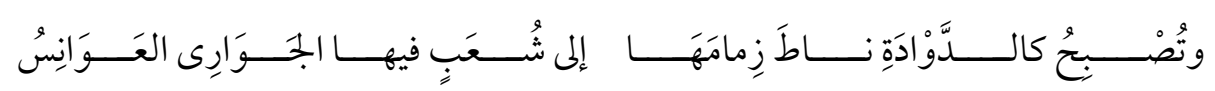

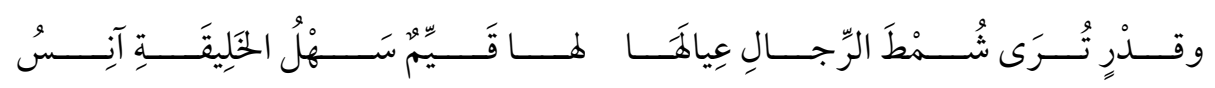

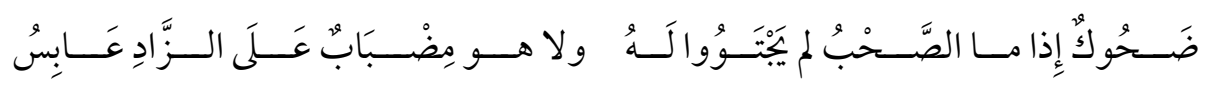

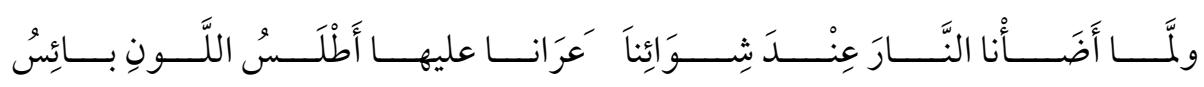

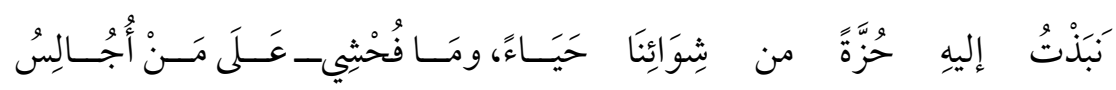

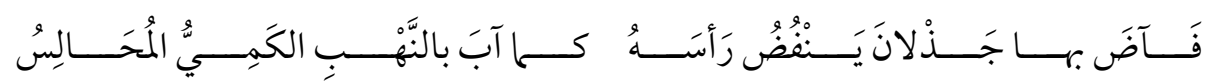

(1) هذا الملحقُ يتضمنُ القصائدَ الثلاث الطليةً للمرقشِ الأكبر ، تلك التي أجرينا عليها الدراسةَ التحليليةً والناقدية . 
ב= المجلا الأول من العدد الخامس والعثرين لحولية كلية الدراسات الإسلامية والعربية للبنات - بالإسكندرية عـ المقدمة الطليلة فى شعر المرقش الأكبر - دراسة تحليلية ونقدية

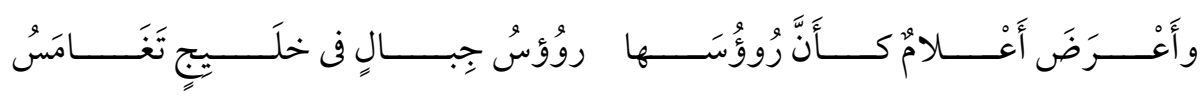

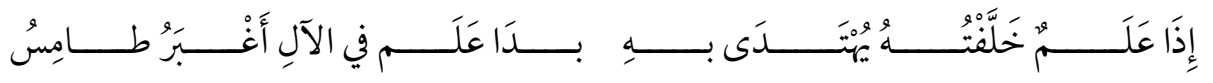

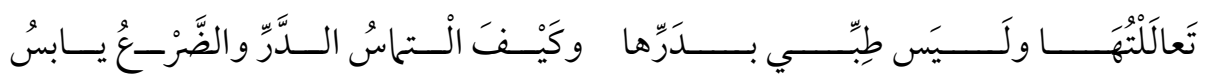

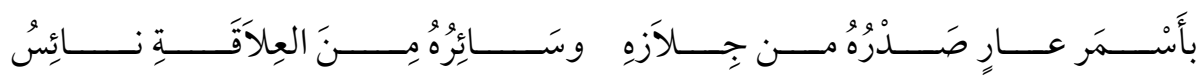

\section{القصيدة الثانية: يقول المرقش الأكبر}

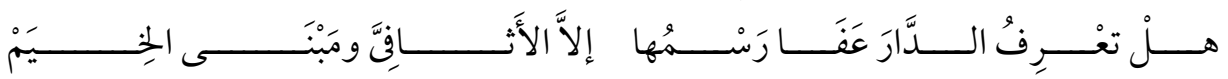

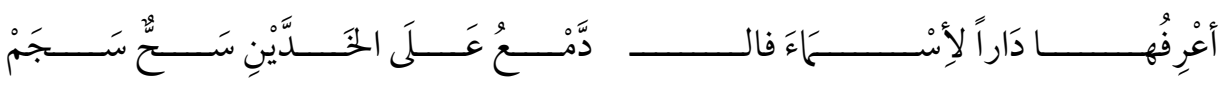

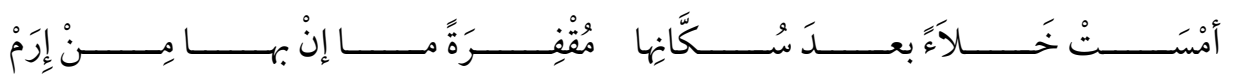

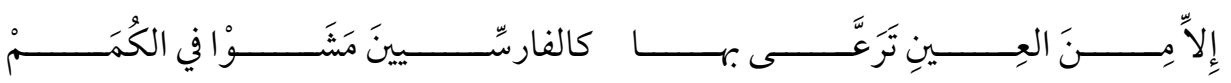

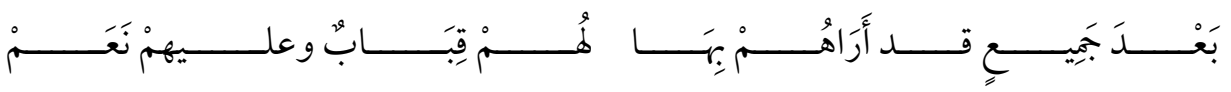

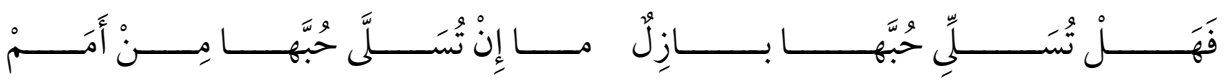

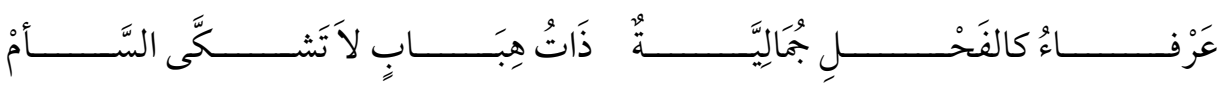

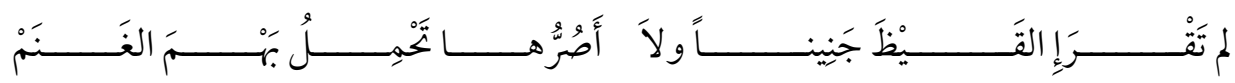

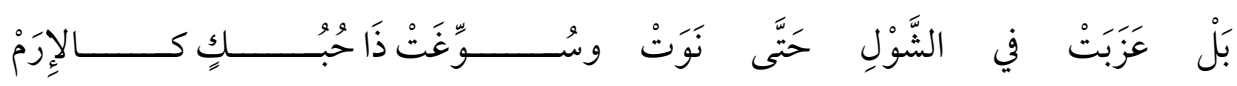
تَعْدُو كأنَّهُ

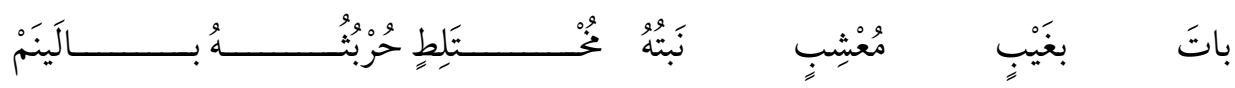


=

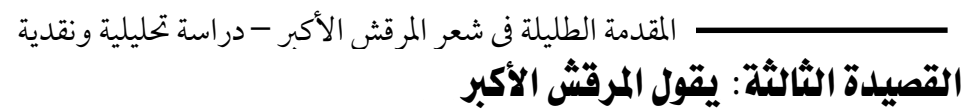

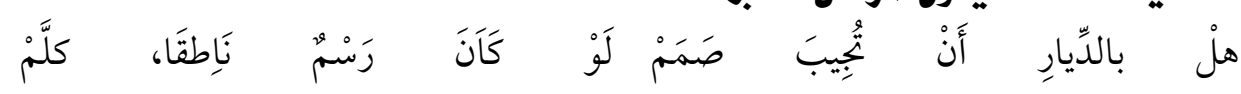

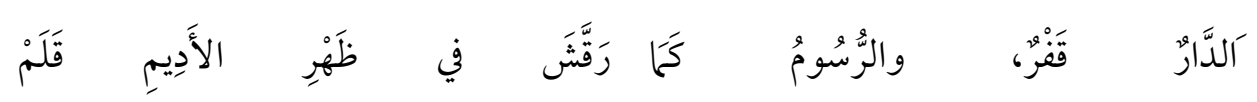

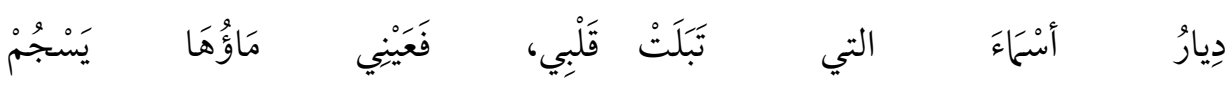

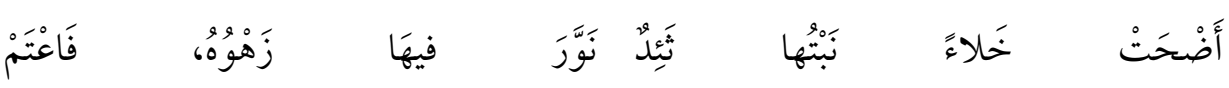

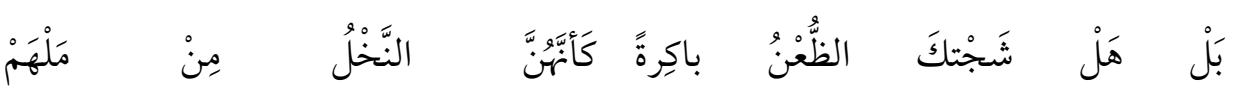

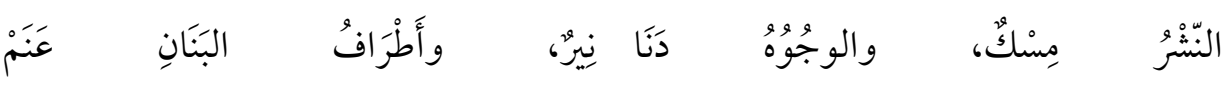

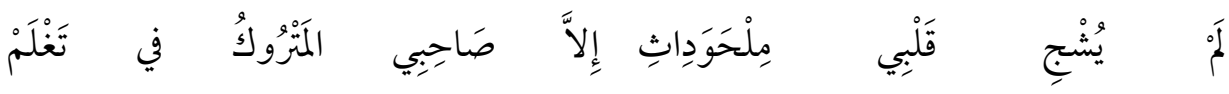

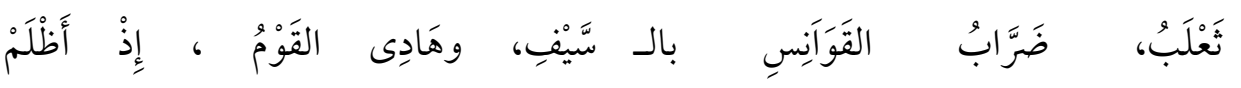

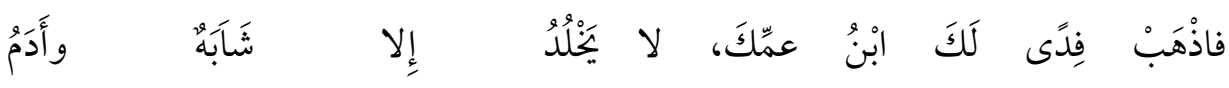

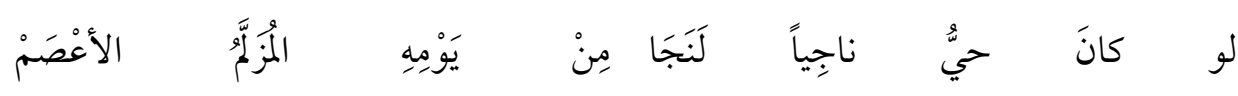
في لِ باذِخاتٍ

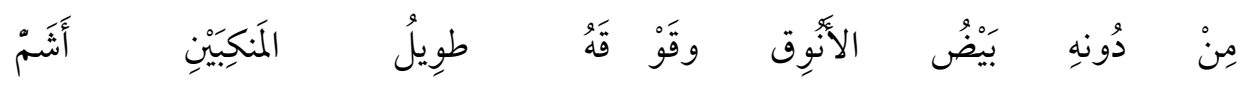

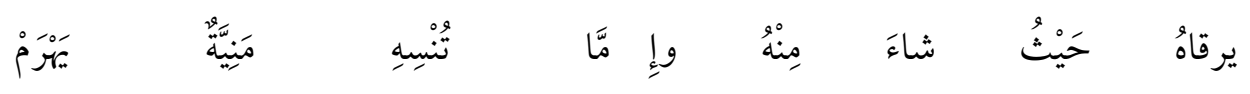

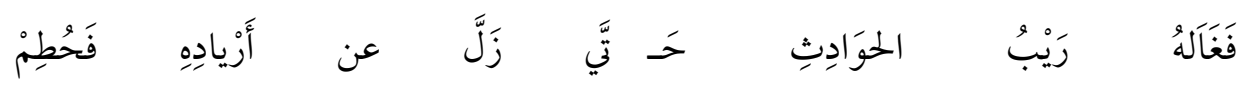

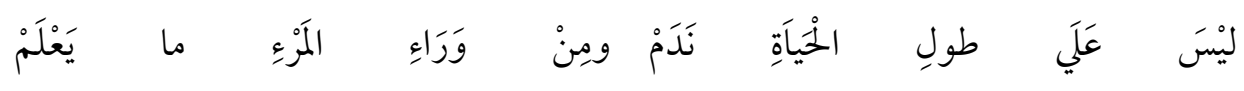

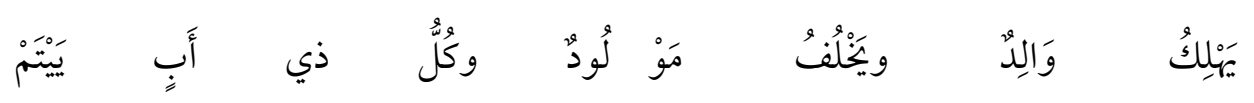

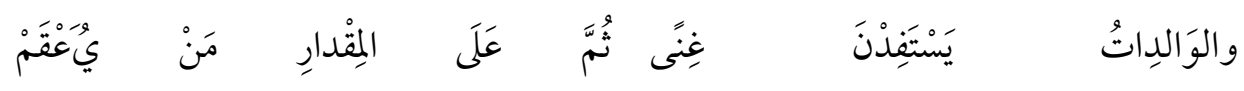

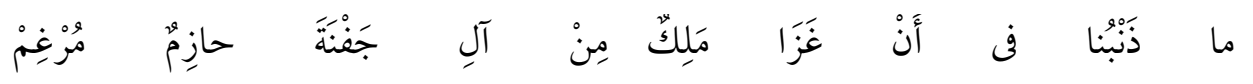
$119 \leq$ 
= المجلد الأول من العدد الخامس والعثرين لحولية كلية الدراسات الإسلامية والعربية للبنات - بالإسكندرية سل المقدمة الطليلة فى شعر المرقش الأكبر - دراسة تحليلية ونقدية

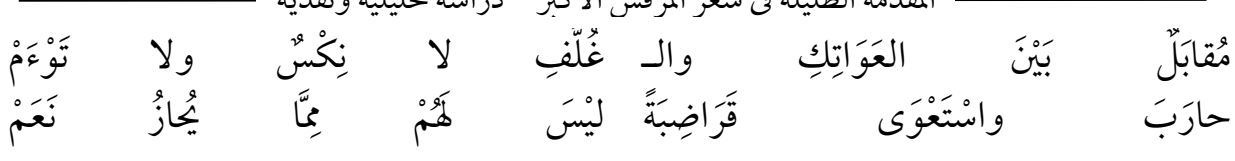

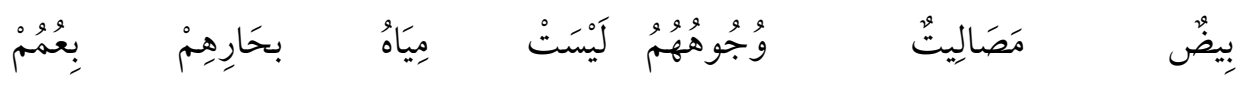

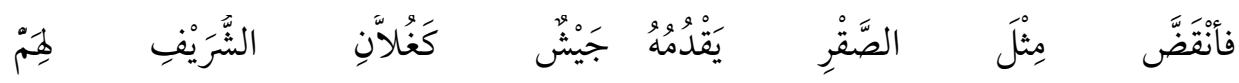

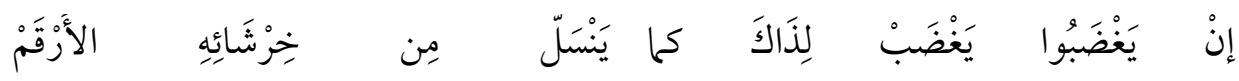

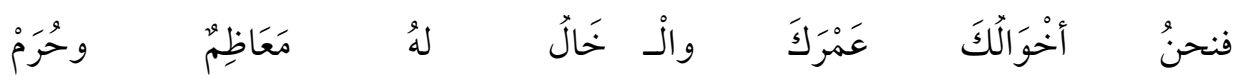

لَنْنَا كأَقْوَامٍ

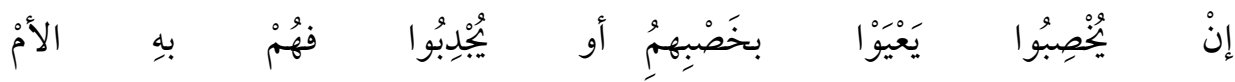

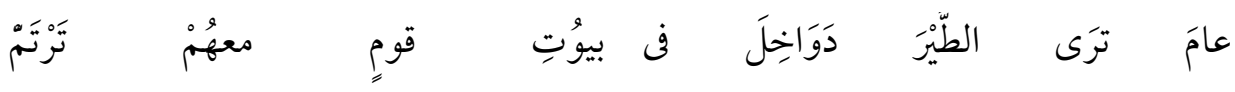

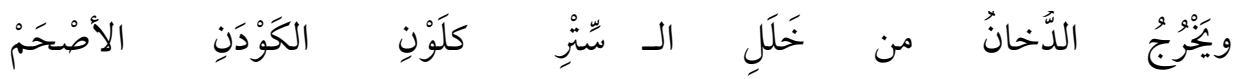

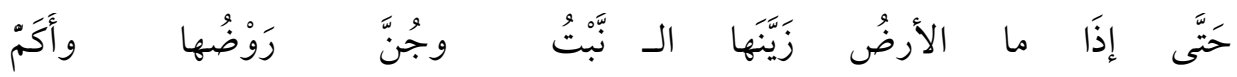
ذَاقِوا لكِنَّنَا أَمْوَالُنان أنَقِي

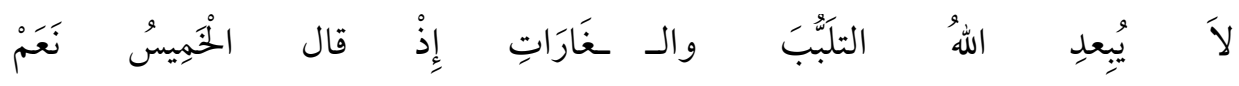
والعَدْوَ بَيْنَ

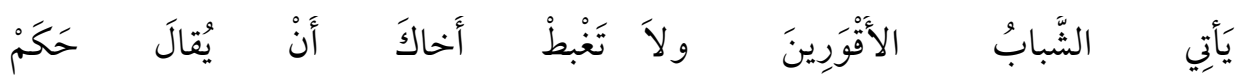




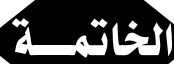

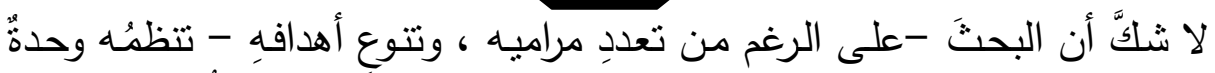

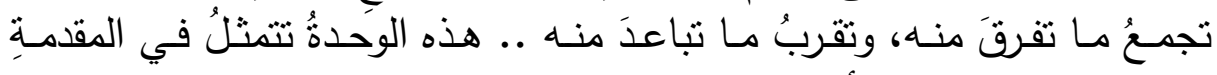

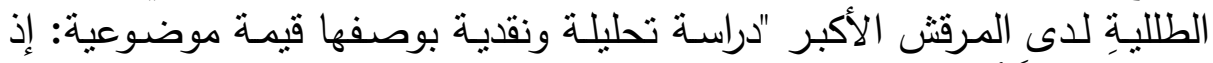

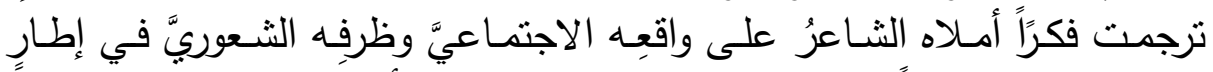

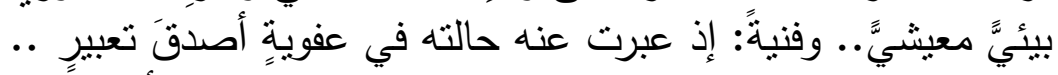

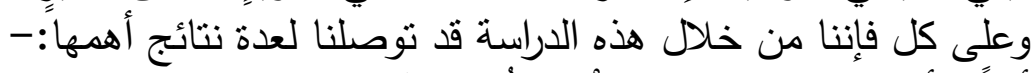

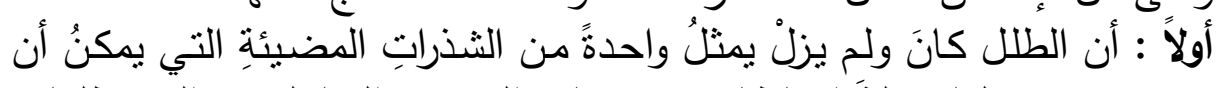

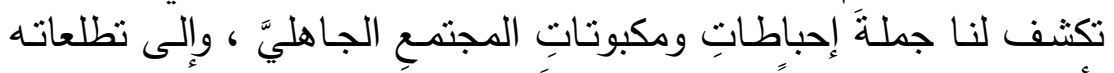

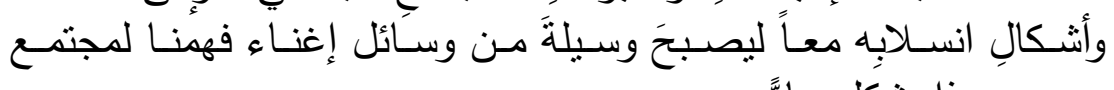

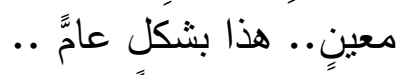

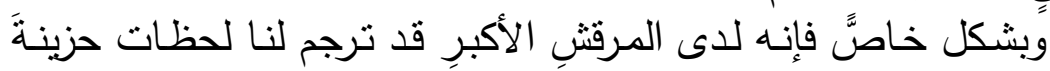

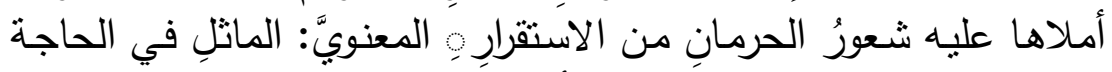

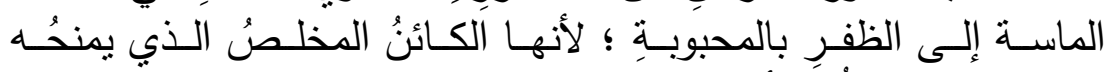

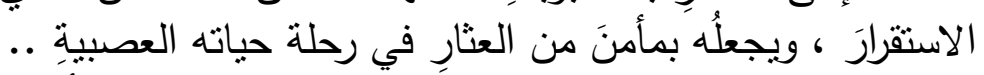

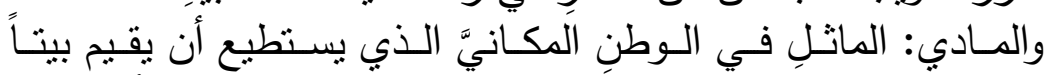

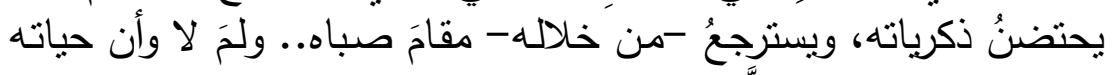

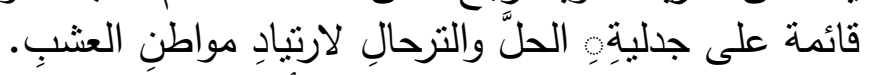

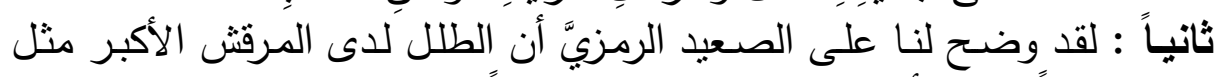

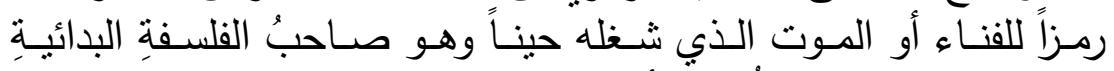

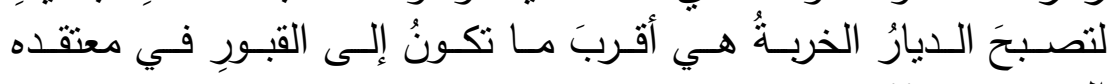

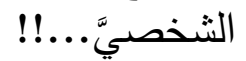

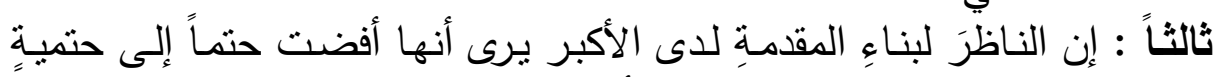

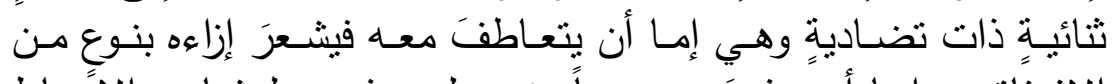

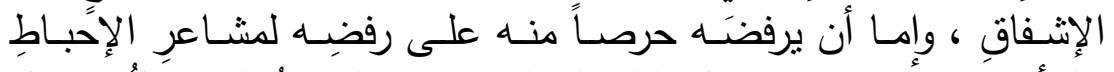

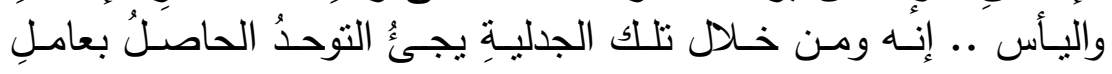

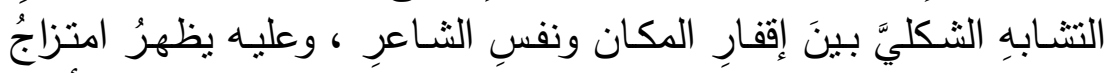

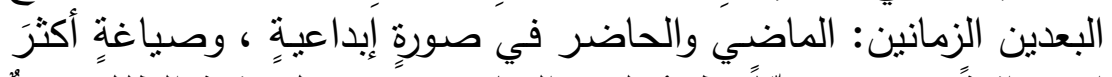

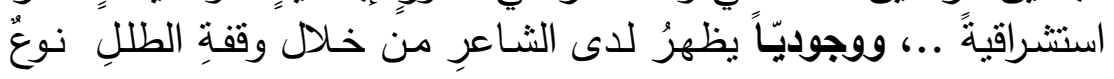

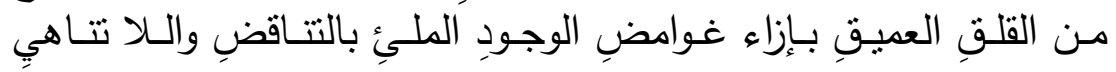




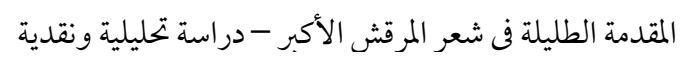

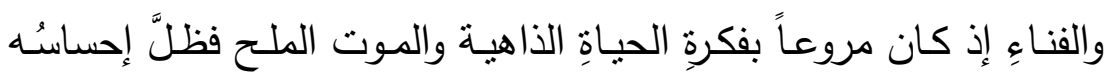

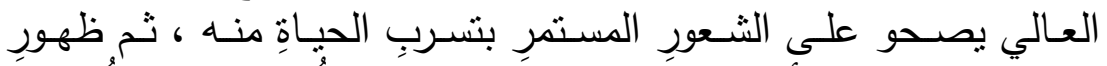

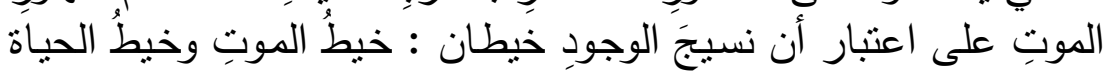

رابعاً : أن لوحة الطلل لدى الأكبر قد اكتملت عناصرُها ذات الطبيعهِة الأرضيةِ

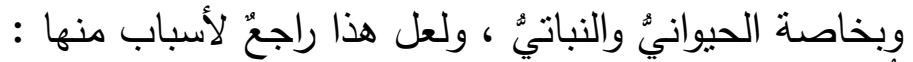

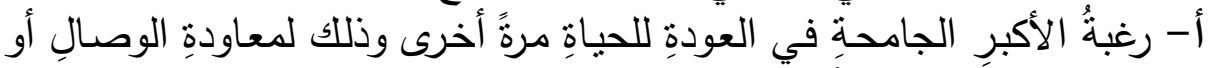

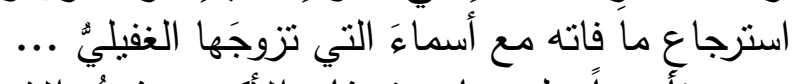

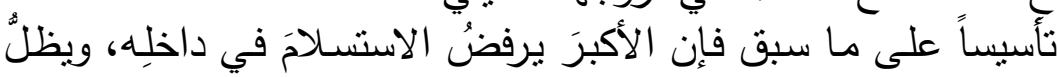

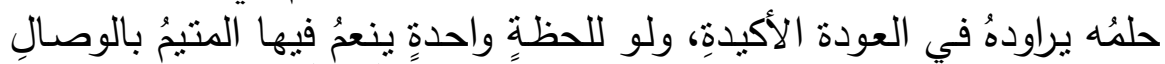

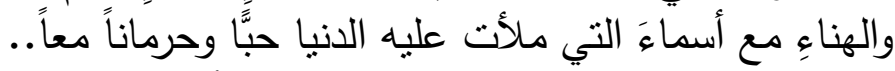

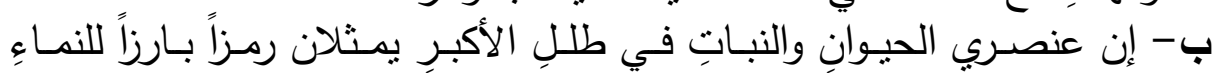

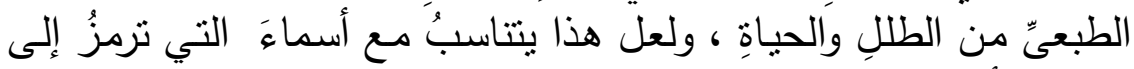

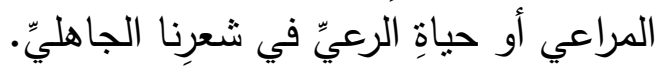

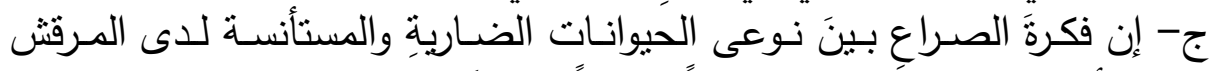

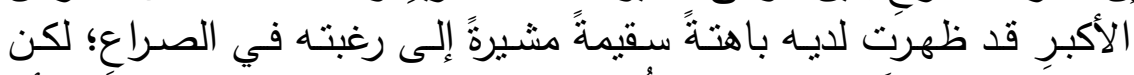

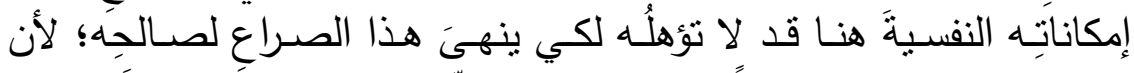

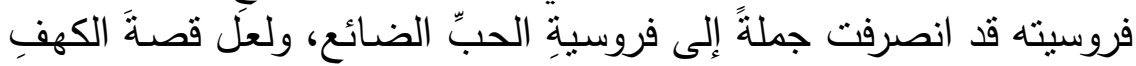

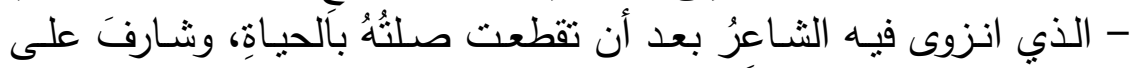

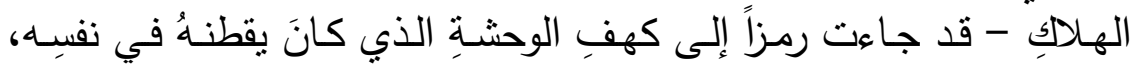
وكذلك نظراته السوداوية للحياةِ.

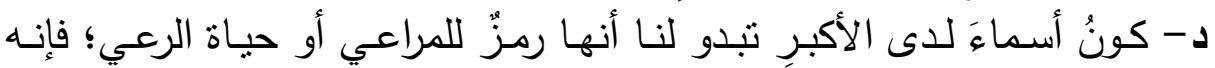

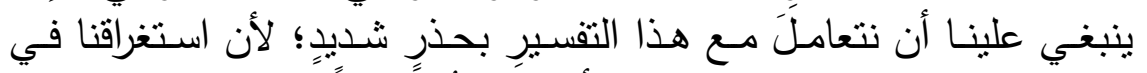

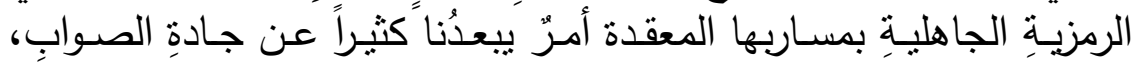
وعدمج الفهرج الواعي لقضايا الجاهلية..

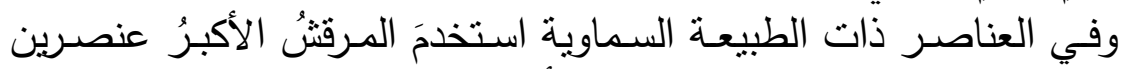

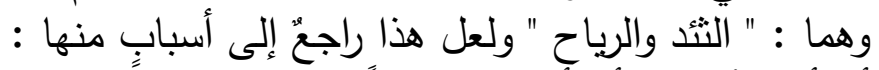

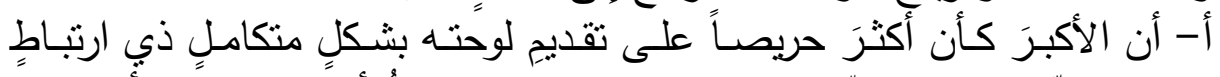

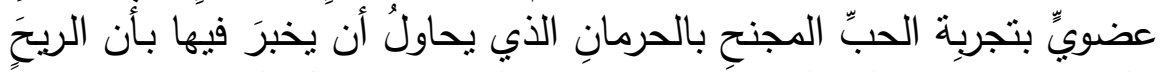

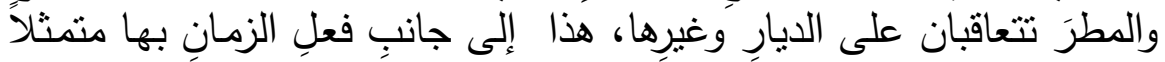




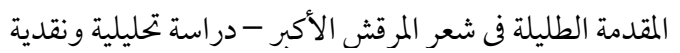

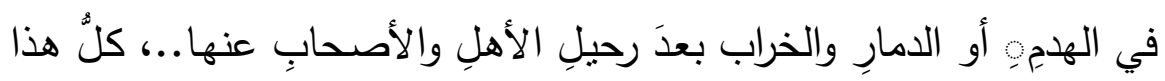

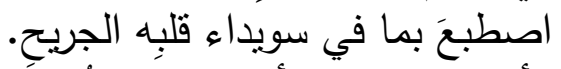

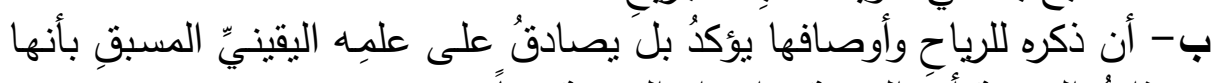

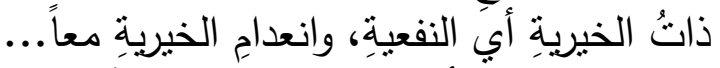

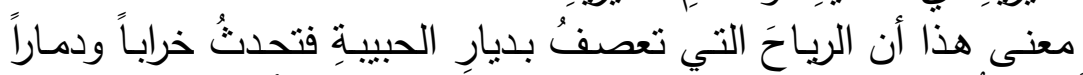

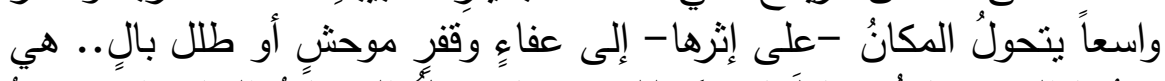

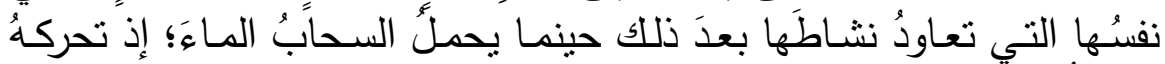

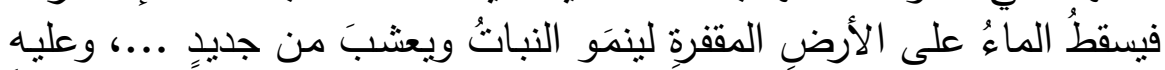

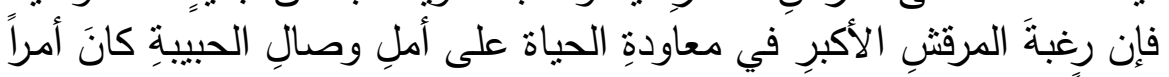

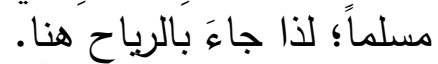

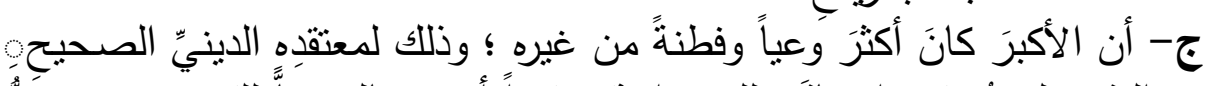

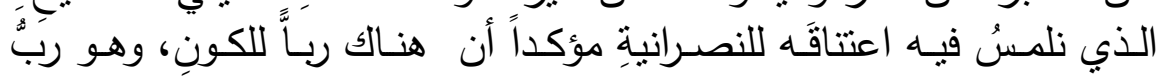

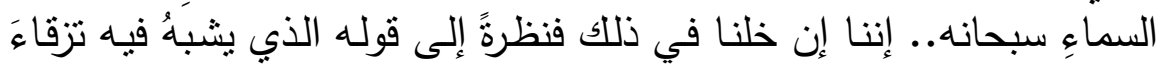

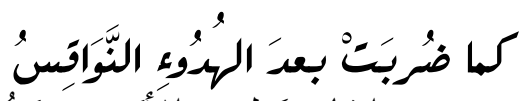

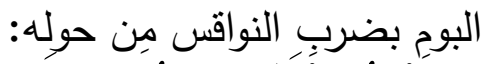

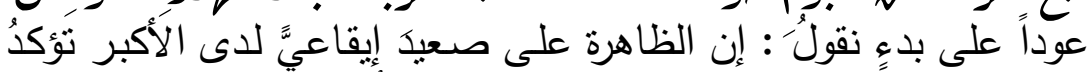

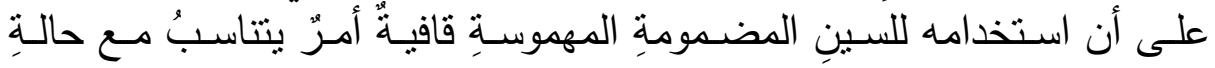

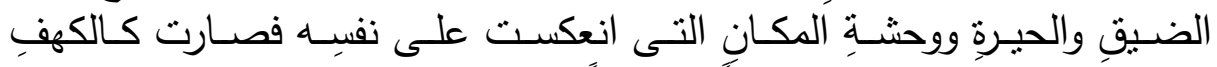

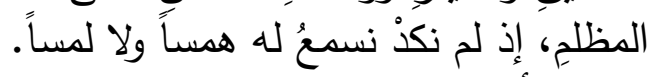

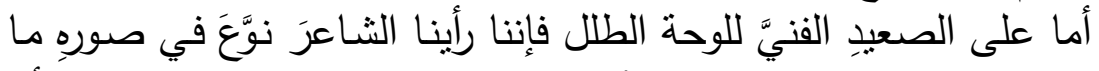

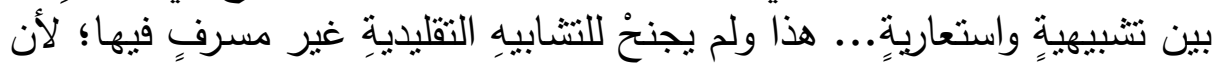

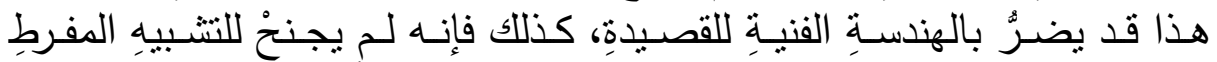

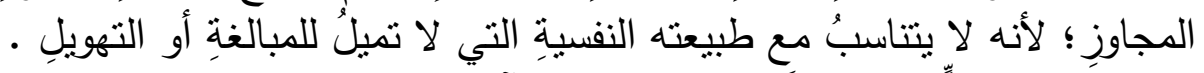

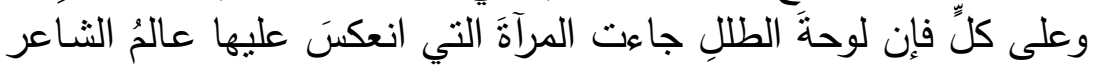
الظاهريٌّ والباطنيٌٌ معا. 


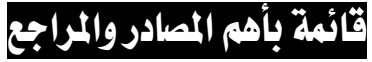

\author{
أولاً: المصادر
}

الـ القرآن الكريم، والسنة النبوية المطهرة "سنن أبى داود ط دار الكتب العلمية- بيروت".

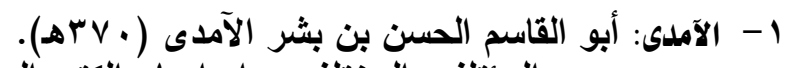

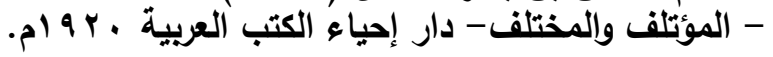

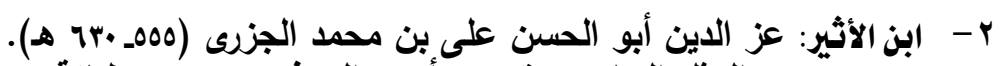

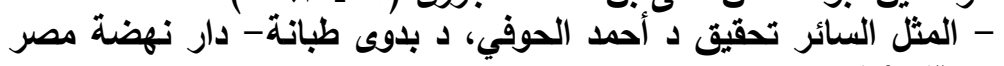

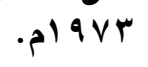

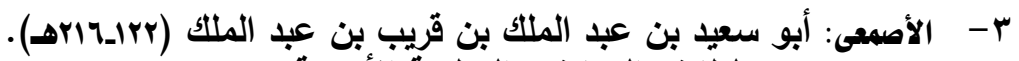

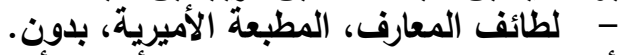

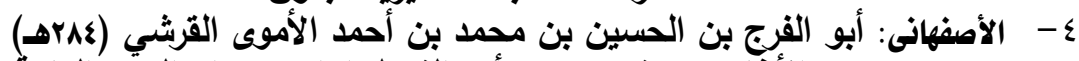

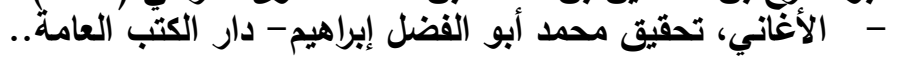

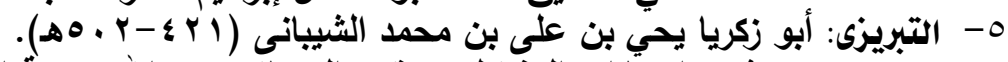
- شرح اختبارات المفضل، تحقيق الحساني عبد الله-مكتبة الخانجي.

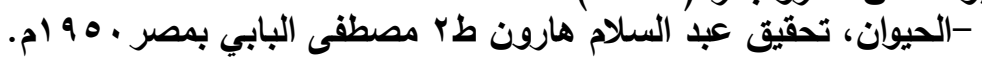

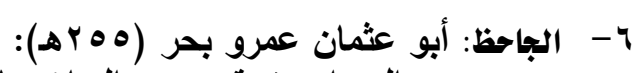

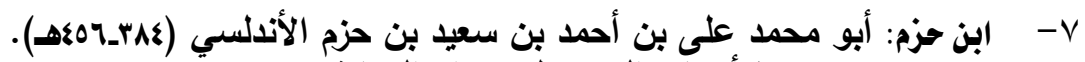

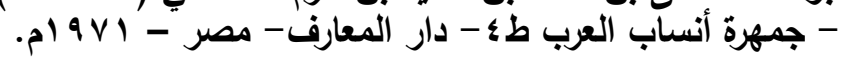

$$
\begin{aligned}
& \text { A- ابن خلدون: عبد أحمد بن خلاون ( • • آمه): }
\end{aligned}
$$

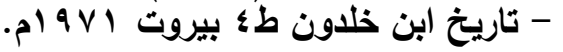

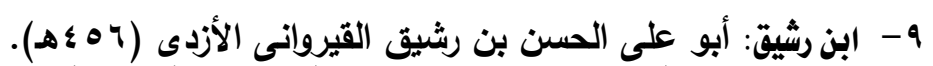

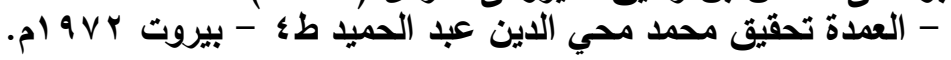

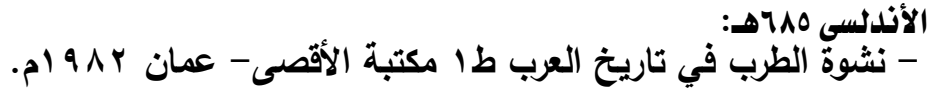

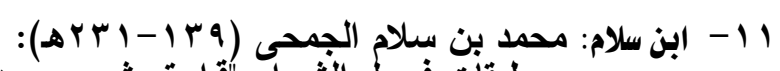

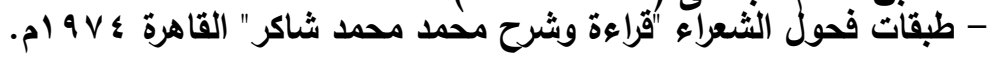

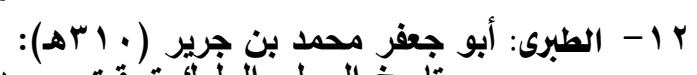

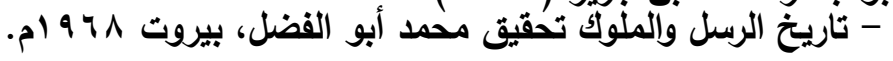

rا

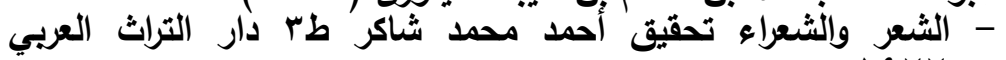

$$
\text { . } 19 \text { V V }
$$

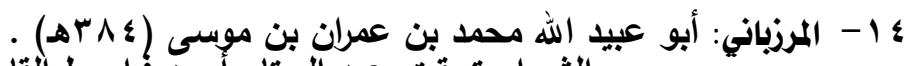

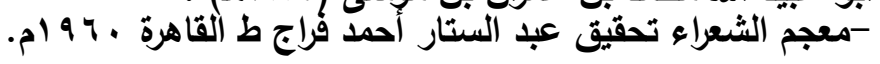




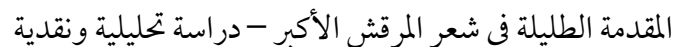

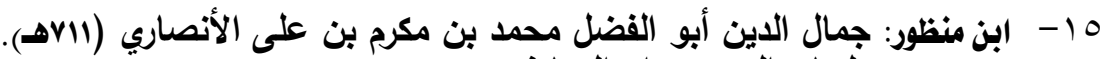

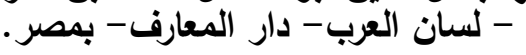

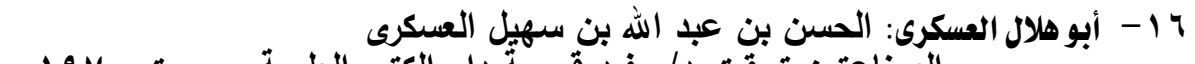

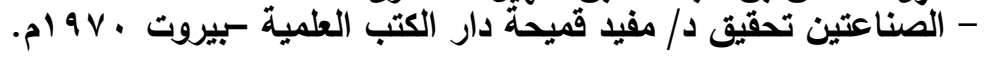

$$
\begin{aligned}
& \text { - الأوائل - دار الكتب العلمية- بيروت - } 1 \text { - }
\end{aligned}
$$

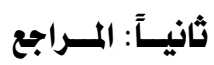

اـ إبراهيم أنيس (دكتور): موسيقى الشعر طهمكتبة الأنجلو المصرية- القاهرة - 191 ام م.

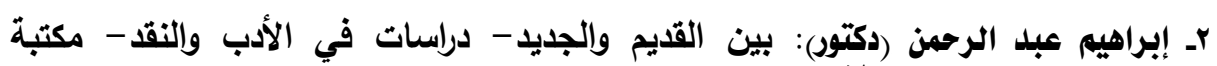

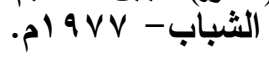

rـ سيد أحمد إسماعيل الفنيمي (دكتور): الأسطورية في الشعر العربي قبل الإسلام- دار سينا

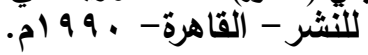

كـ حسن البنا عز الديز (دكتور): - الكلمات والأثياء "بحث في التقاليد القتية للقصيدة الجاهلية، دار الكتاب المباء

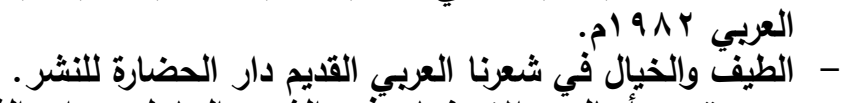

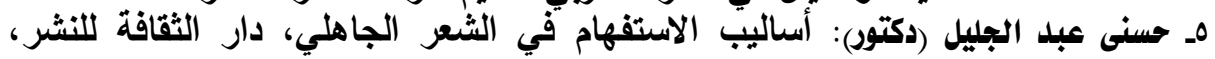
. 199 .

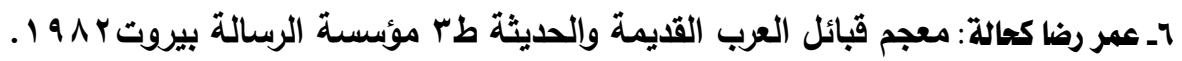

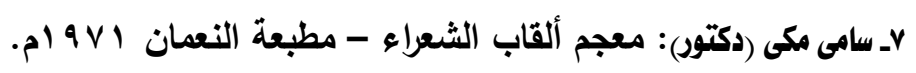

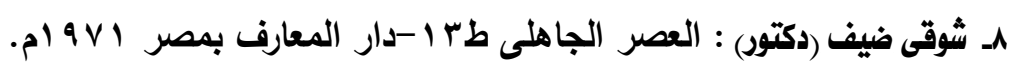

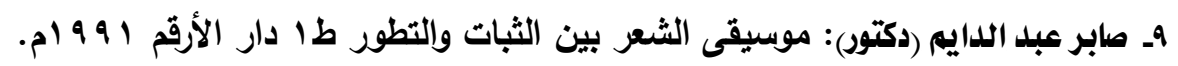

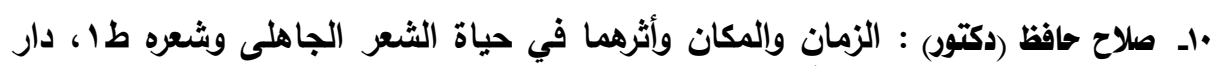

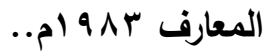

الـ عبد الفتاح عثمان (دكتور): النقد العربي القديم أصوله، مناهجه، قضاياه طاه ا، دار العدالة

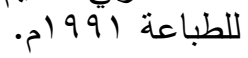

rاـ محمد شبل (دكتور): المذاهب النقدية الحديثة- مدخل فلسفي - الهيئة المصرية للكتاب.

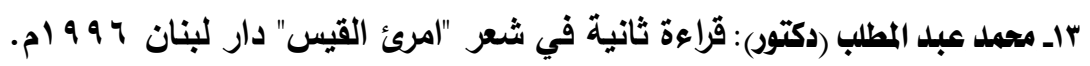

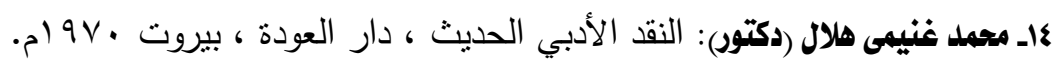

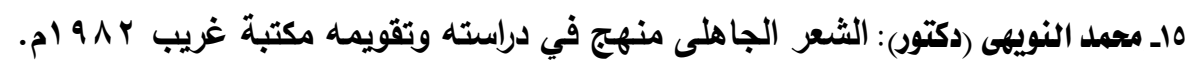

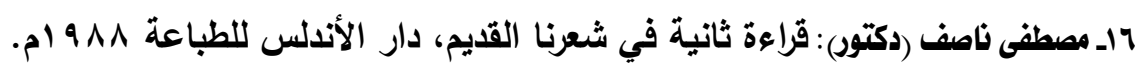

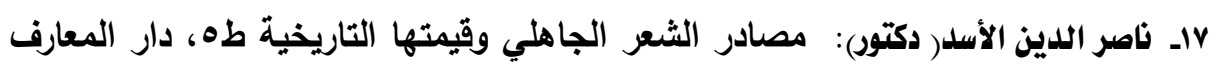

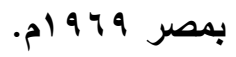


= المجلد الأول من العدد الخامس والعثرين لحولية كلية الدراسات الإسلامية والعربية للبنات - بالإسكندرية عـ المقدمة الطليلة في شعر المرقش الأكبر - دراسة تحليلية ونقدية

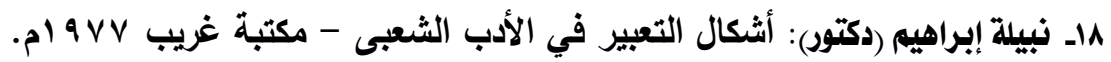

19ـ نصرت عبد الرحمن(دكتور): الصورة الفنية في الشعر الجاهلي في ضوء النقد الحديث-

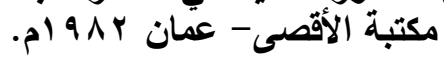

•rـ نودى حمودى الثيسي (دكتور): الطبيعة في الشعر الجاهلى -دار الإرشاد- طا، بيروت . $19 \mathrm{~V}$.

rr. وهبة رومية (دكتور): شعرنا القديم والنقد القديم- عالم المعرفة 9 ـ ام.

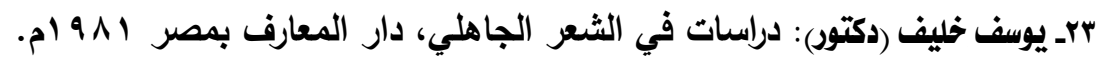
צr- يوسف اليوسف (دكتور): مقالات في الشعر الجاهلى طץ دار الفكر - بدون تاريخ. ثالثاً: من المجلات العربية والدوريات

ا - مجلة العرب: العدد السادس، السنة الرابعة، فبراير . 9 ام.

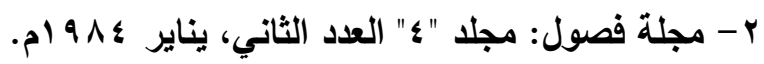
r- مجلة المعرفة السورية: عدد حزيران به 9 ام. 